\author{
UNIVERSIDADE DE SÃO PAULO \\ MUSEU DE ARQUEOLOGIA E ETNOLOGIA \\ PROGRAMA DE PÓS-GRADUAÇÃO EM ARQUEOLOGIA \\ DAVID LUGLI TURTERA PEREIRA
}

ARQUEOLOGIA DA PAISAGEM APLICADA AO ESTUDO DOS SÍTIOS ARQUEOLÓGICOS NA BACIA DO RIO TURVO-GRANDE, REGIÃO NORTE DO ESTADO DE SÃO PAULO

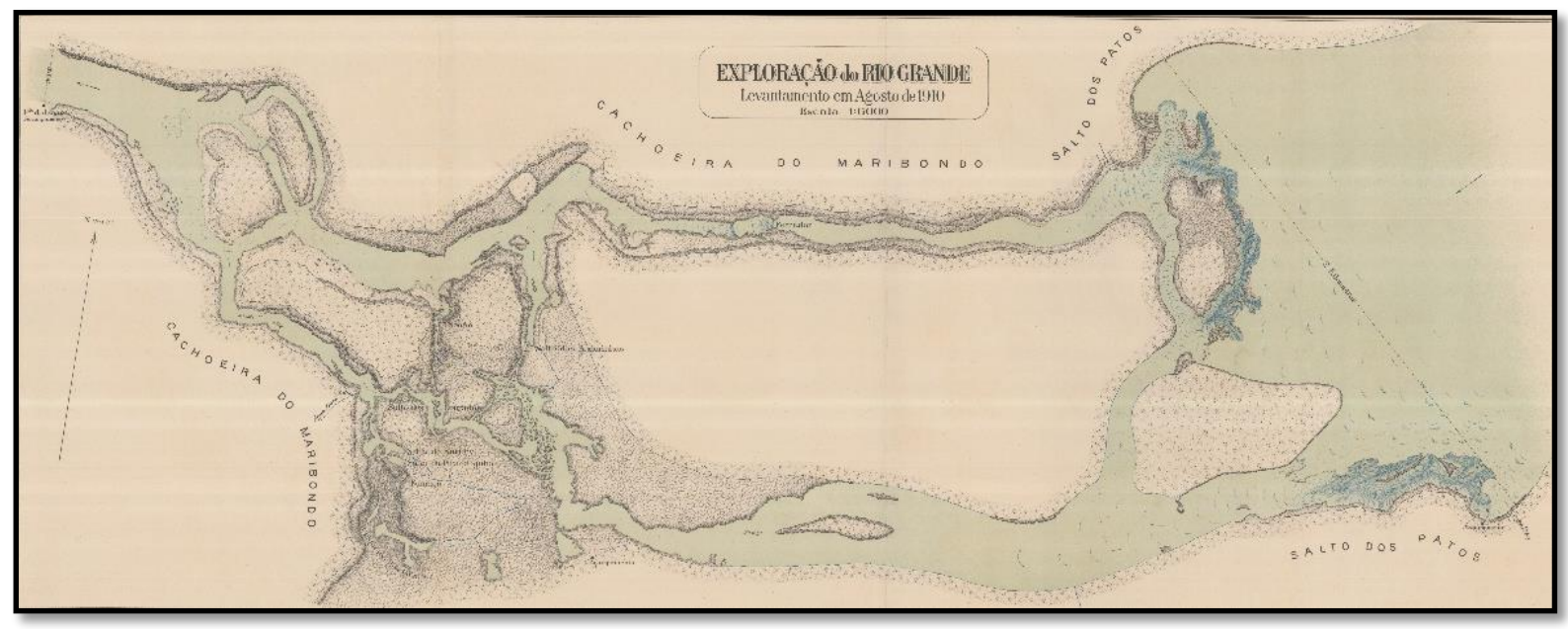

Fonte: Comissão Geológica e Geográfica do estado de São Paulo (1913) 


\author{
UNIVERSIDADE DE SÃO PAULO \\ MUSEU DE ARQUEOLOGIA E ETNOLOGIA \\ PROGRAMA DE PÓS-GRADUAÇÃO EM ARQUEOLOGIA \\ DAVID LUGLI TURTERA PEREIRA
}

\title{
ARQUEOLOGIA DA PAISAGEM APLICADA AO ESTUDO DOS SÍTIOS ARQUEOLÓGICOS NA BACIA DO RIO TURVO-GRANDE, REGIÃO NORTE DO ESTADO DE SÃo PAULO
}
Tese apresentada ao Programa de Pós-Graduação em Arqueologia do Museu de Arqueologia e Etnologia da Universidade de São Paulo.

Área de Concentração: Arqueologia

Orientador: Profa. Dra. Neide Barroca Faccio

Linha de Pesquisa 2: Arqueologia e Ambiente 
Autorizo a reprodução e divulgação integral ou parcial deste trabalho, por qualquer meio convencional ou eletrônico, para fins de estudo e pesquisa, desde que citada a fonte.

\section{CATALOGAÇÃO NA PUBLICAÇÃO (CIP) \\ Serviço de Biblioteca e Documentação do}

Museu de Arqueologia e Etnologia da Universidade de São Paulo

\section{P436 Pereira, David Lugli Turtera.}

Arqueologia da paisagem aplicada ao estudo dos sítios arqueológicos na bacia do rio Turvo-Grande, região norte do estado de São Paulo / David Lugli Turtera Pereira ; orientadora Neide Barroca Faccio. -- São Paulo, 2017.

Tese (Doutorado) - Universidade de São Paulo, Museu de Arqueologia e Etnologia, Programa de PósGraduação em Arqueologia, 2017.

1. Arqueologia da paisagem. 2. Contexto arqueológico regional. 3. Bacia do rio Turvo-Grande. 4. Sistema Regional de Povoamento. 5. Norte do estado de São Paulo. I. Faccio, Neide Barroca. II. Universidade de São Paulo. Museu de Arqueologia e Etnologia. Programa de Pós-Graduação em Arqueologia. III. Título. 
À minha família, à minha companheira e aos queridos amigos que vivenciaram com muito amor e paciência esse longo período de maturação. 


\section{AGRADECIMENTOS}

À Profa. Dra. Neide Barrocá Faccio pela orientação, companheirismo e amizade que já perduram mais de uma década.

À toda equipe do Laboratório de Arqueologia Guarani e Estudos da Paisagem (LAG/FCT/UNESP) de ontem e de hoje. A expressiva equipe coordenada pela Profa. Neide Barrocá Faccio é responsável pela publicação de muitos trabalhos acadêmicos desenvolvidos, muitas vezes, de forma coletiva e colaborativa.

Aos amigos Hiuri Marcel Di Baco, Juliana Aparecida Luz, Thiago Passos e André Alves pelas infindáveis discussões e trabalhos de campo na área de arqueologia.

Ao Prof. Dr. José Luiz de Morais por incentivar e apoiar o nosso percurso na pósgraduação em arqueologia pelo MAE-USP.

Ao Prof. Dr. Luiz Antônio Barone pela amizade, conversas e parcerias de trabalho.

Aos professores do MAE-USP responsáveis por nossa formação teórica. Em especial ao Prof. Dr. Eduardo Góes Neves e Profa. Dra. Fabíola Silva por terem mostrado de forma tão bela o que a arqueologia representa para o conhecimento da ocupação humana no passado e como ela repercute no presente.

À CAPES que financiou a pesquisa, possibilitando a tranquilidade e o tempo necessário para o desenvolvimento da tese.

Ao Instituto Terra e Memória sediado na cidade de Mação, Portugal, representado pelo Prof. Dr. Luiz Oosterbeek, por ter concedido produtivo estágio de pesquisa em suas dependências.

Aos amigos de diferentes nacionalidades que conheci durante o estágio em Mação. Quero dizer que foram ótimas às resenhas e as conversas. Em uma dessas noites descobri que "pequenos passos constroem grandes histórias".

Aos amigos de todos os tempos. Seria difícil citar um a um, mas guardo na memória e no coração as conversas, devaneios, noites longas e de muitos aprendizados com cada um de vocês.

A minha companheira querida, Erica Villas Boas Cunha, que esteve presente em todo esse percurso. Sua paciência e seu amor foram fundamentais nessa minha trajetória. Guardarei isso para sempre no coração.

A minha família, representada por meus pais, irmãos, cunhada, cunhado, sogro, sogra e sobrinhas queridas. O aconchego familiar, os almoços, festas e amizade é arcabouço fundamental para meu sucesso em qualquer caminho que decida tomar. 
Às dezenas, se não centenas, de pessoas que fizeram parte desse trajeto e não foram aqui mencionadas. Funcionários das instituições em que pesquisei, professores que conversei, alunos de cursos variados de graduação, pós graduação etc em que dialoguei, formam peças chaves para o desenvolvimento intelectual e ético de qualquer pesquisador. 
O homem terra foi, vasilha, pálpebra do barro trêmulo, forma de argila, foi cântaro caraíba, pedra chibcha, taça imperial ou sílica araucana. Terno e sangrento foi, porém no punho de sua arma de cristal umedecido as iniciais da terra estavam escritas. Ninguém pôde recordá-las depois: o vento as esqueceu, o idioma da água foi enterrado, as chaves se perderam ou se inundaram de silêncio ou sangue. Não se perdeu a vida, irmãos pastorais.

Mas como uma rosa selvagem caiu uma gota vermelha na floresta e apagou-se uma lâmpada da terra. (NERUDA, 2010, p.21) 


\section{RESUMO}

Esta pesquisa apresenta alguns resultados do trabalho realizado com enfoque na arqueologia da paisagem em sítios arqueológicos localizados na Bacia Hidrográfica do Rio Turvo-Grande. Os procedimentos de campo foram iniciados no ano de 2011 e finalizados no ano de 2014, permitindo-nos avaliar o tipo e a intensidade de materiais arqueológicos, sua distribuição na paisagem, os aspectos geoambientais relevantes para a ocupação pretérita e os processos de formação atuantes nesses registros.

Os dados colhidos em campo foram compilados em linguagem cartográfica, o que permitiu gerar informações espaciais dos sítios arqueológicos, bem como compreender sua possível relação com os geoindicadores locais. Os materiais arqueológicos recolhidos foram analisados em laboratório, levantando questões importantes sobre a sua produção, o seu uso e a sua espacialidade intrassítio.

Os sítios arqueológicos trabalhados no âmbito dessa pesquisa foram correlacionados ao contexto arqueológico regional. A análise multiescalar e multidimensional desse contexto permitiu identificar alguns padrões socioespaciais que auxiliaram na compreensão do processo de habitar e transformar às paisagens do norte do estado de São Paulo.

Palavras-Chave: Arqueologia da paisagem; Contexto arqueológico regional; Bacia do rio Turvo-Grande, Sistema Regional de Povoamento, Norte do estado de São Paulo. 


\begin{abstract}
This research presents some results of the work fulfilled with focus on the landscape archaeology in archeological sites located in the Turvo-Grande River Basin. Field procedures were initiated in 2011 and finalized in 2014, allowing us to evaluate the type and intensity of archaeological materials, their distribution in the landscape, the geoenvironmental aspects relevant to the past occupation and the formation processes in these records.

The data collected in the field were compiled in cartographic language, which allowed to engender spatial information of the archaeological sites, furthermore to understand its possible relation with the local geoindicators. The collected archaeological materials were analyzed in the laboratory, raising important questions about its production, its use and its intrasite spatial. The archaeological sites worked within this research were correlated to the regional archaeological context. The multiscale and multidimensional analysis of this context allowed the identification of some socio-spatial patterns that helped to understand the process of dwelling and transforming the landscapes of the north of the state of São Paulo.
\end{abstract}

Keywords: Landscape archeology; Regional archaeological context; Turvo-Grande River Basin, Regional settlement system, North of the state of São Paulo. 


\section{LISTA DE FIGURAS}

Figura 1 - Localização dos sítios arqueológicos nos Municípios de Paulo

de Faria, Orindiúva e Icém

Figura 2 - Localização dos sítios arqueológicos segundo nível temporal $\quad 76$

Figura 3 - Localização dos grupos ceramistas no Brasil Central 82

Figura 4 - Distribuição das tradições ceramistas do estado de São Paulo 91

Figura 5 - Localização dos sítios arqueológicos nas bacias hidrográficas 93 do CAR

Figura 6 - Hipsometria dos sítios arqueológicos localizados no CAR

94

Figura 7 - Distribuição dos sítios arqueológicos filiados a tradições 104 arqueológicas no CAR

Figura 8 - Distribuição dos sítios arqueológicos no primeiro cenário de 105 ocupação agricultora ceramista no CAR

Figura 9 - Distribuição dos sítios arqueológicos no segundo cenário de ocupação agricultora ceramista no CAR.

Figura 10 - Distribuição dos sítios arqueológicos no terceiro cenário de ocupação agricultora ceramista no CAR

Figura 11- Distribuição dos sítios arqueológicos no quarto cenário de 108 ocupação no CAR

Figura 12 - Distribuição dos sítios arqueológicos por cenários de ocupação no CAR

Figura 13 - Território Kayapó Meridional

Figura 14 - Distribuição dos Sítios Arqueológicos e Áreas de Ocorrência nas classes geomorfológicas

Figura 15 - Distribuição dos Sítios Arqueológicos e Áreas de Ocorrência nas estruturas geológicas

Figura 16 - Distribuição dos Sítios Arqueológicos e Áreas de Ocorrência na cobertura pedológica

Figura 17 - Distribuição dos Sítios Arqueológicos e Áreas de Ocorrência na cobertura vegetal 
Figura 19 - Dispersão dos materiais arqueológicos do Sítio Barra de Ouro

Figura 20 - Localização do Sítio Porto Velho I

Figura 21 - Dispersão dos materiais arqueológicos do Sítio Porto Velho I

Figura 22 - Localização do Sítio Porto Velho II

Figura 23 - Dispersão dos materiais arqueológicos no sítio Porto Velho II

Figura 24 - Gráfico de precipitação desde de Novembro de 2012 e média de precipitação a Longo Termo do Estado de São Paulo.

Figura 25 - Gráfico de vazão natural e volume útil da represa UHE Marimbondo desde Julho de 2012

Figura 26 - Quadra A1 N1. Localização de vestígios arqueológicos na área de decapagem do Sítio Menino Jesus.

Figura 27 - Quadra A1 N2. Localização de vestígios arqueológicos na área de decapagem do Sítio Menino Jesus.

Figura 28 - Quadra A1 N3. Localização de vestígios arqueológicos na área de decapagem do Sítio Menino Jesus.

Figura 29 - Quadra A2 N1. Localização de vestígios arqueológicos na área de decapagem do Sítio Menino Jesus.

Figura 30 - Quadra A2 N2. Localização de vestígios arqueológicos na área de decapagem do Sítio Menino Jesus.

Figura 31 - Quadra B2 N1. Localização de vestígios arqueológicos na área de decapagem do Sítio Menino Jesus.

Figura 32 - Quadra B2 N2. Localização de vestígios arqueológicos na área de decapagem do Sítio Menino Jesus.

Figura 33 - Quadra C2 N1. Localização de vestígios arqueológicos na área de decapagem do Sítio Menino Jesus.

Figura 34 - Quadra C2 N2. Localização de vestígios arqueológicos na área de decapagem do Sítio Menino Jesus.

Figura 35 - Quadras de decapagem na área de escavação do sítio arqueológico Menino Jesus.

Figura 36 - Dispersão dos pontos de coleta na área do Sítio Arqueológico 
Figura 37 - Localização de depósitos de argila, nascentes e cascalheira na área do Sítio Menino Jesus

Figuras 38 e 39 - Reconstituição de cerâmica do Sítio Arqueológico 198 Menino Jesus, Município de Icém, SP.

Figuras 40 e 41: Reconstituição de decoração pintada, presente em 200 fragmento de cerâmica. Sítio Arqueológico Menino Jesus, município de Icém, SP.

Figuras 42 e 43 - Reconstituição de decoração pintada, presente em 201 fragmento de cerâmica. Sítio Arqueológico Menino Jesus, município de Icém, SP.

Figuras 44 e 45 - Reconstituição de decoração pintada, presente em 201 fragmento de cerâmica. Sítio Arqueológico Menino Jesus, município de Icém, SP.

Figuras 46 e 47 - Reconstituição de decoração pintada, presente em 201 fragmento de cerâmica. Sítio Arqueológico Menino Jesus, município de Icém, SP.

Figura 48 - Conjuntos dos fragmentos de bordas reconstituídas do sítio 203 arqueológico Menino Jesus

Figura 49 - Mapa de dispersão dos fragmentos de cerâmica do Sítio 206 Arqueológico Menino Jesus

Figura 50 - Mapa de dispersão dos fragmentos de bordas reconstituídas do Sítio Arqueológico Menino Jesus

Figura 51 - Mapa de dispersão dos líticos lascados do Sítio Arqueológico 209 Menino Jesus

Figura 52 - Mapa de dispersão dos líticos polidos do Sítio Arqueológico Menino Jesus

Figura 53 - Possíveis rotas de acesso aos recursos naturais na área de entorno do sítio Menino Jesus.

Figura 54 - Localização e ilustração do sítio arqueológico Santa Filomena

Figura 55 - Planta de escavação da trincheira do sítio Santa Filomena

Figura 56 - Aldeamento de São Vicente do Talhadão e área de entorno

Figura 57 - Salto de Água Vermelha, bacia do rio Grande.

Figura 58 - Cachoeira do Marimbondo/Salto dos Patos, bacia do rio Grande. 
Figura 59 - Famílias Linguísticas do Estado de São Paulo, segundo 237 Nimuendaju 1987

Figura 60 - Sistemas Regionais de Povoamento no CAR e suas possíveis 241 rotas de expansão pelo território 


\section{LISTA DE FOTOS}

Foto 1 - Lítico Polido do Sítio Arqueológico Barra de Ouro.

Foto 2 - Lasca de arenito silicificado coletada no Sítio Arqueológico Porto Velho I

Foto 3 - Fragmento de Pedra Polida coletado no Sítio Porto Velho I

Foto 4 - Fragmento de borda, provavelmente, pertencente a um vaso conjugado. Sítio Porto Velho I

Foto 5 - Lasca de arenito silicificado coletada no Sítio Arqueológico Porto

Velho II

Foto 6 - Vista Panorâmica da área do sítio e de seu entorno. A seta laranja indica a faixa de depleção onde foram coletados materiais líticos e afloramentos de basalto. A seta vermelha indica as águas do Córrego Menino Jesus represada. A seta preta indica o canal principal do Rio Grande.

Foto 7 - Lítico polido (mão de pilão fragmentada).

Foto 8 - Afloramento de basalto na margem direita do Córrego Menino Jesus.

Foto 09: Bloco de basalto com dois sulcos em forma de $\mathrm{X}$

Foto 10 - Detalhe no sulco mais profundo.

Fotos 11 e 12 - A Foto 11 registra a represa da UHE-Marimbondo no dia nove de setembro de 2013. A Foto 12 registra o forte decréscimo do volume útil chegando ao fio de água do Córrego Menino Jesus no dia quatro de setembro de 2014

Fotos 13 e 14 - A Foto 13 mostra afloramento de água escoando para o Córrego Menino Jesus em sua margem esquerda. A Foto 14 indica na seta vermelha depósito de argila sendo prospectado e a seta preta indica afloramento de água.

Fotos 15 e 16 - A seta preta da Foto 15 indica o afloramento das raízes de duas Macaúbas. O processo ocorreu por meio da erosão da água que carreou o solo e os vestígios arqueológicos para o fundo de vale. A Foto 16 indica em suas circunferências vermelhas as áreas onde foram coletados materiais arqueológicos na margem esquerda. A seta preta indica a área de concentração 1 e a seta azul a área de concentração 2 .

Foto 17 - Abertura das quadras A1, A2, B2 e C2 na área de concentração 
Fotos 18, 19 e 20: Sequência de imagens que identifica, da esquerda para a direita, a coleta de superfície das quadras C2, B2, A2 e A1

Foto 21 - Escavação do Nível 1 da Quadra 1. A seta preta indica um 177 fragmento de parede, a seta amarela um coquinho de Macaúba e a seta vermelha um fragmento de base. Nota-se o encharcamento do solo devido à proximidade das nascentes de água

Fotos 22 e 23 - As fotos mostram manchas escuras que surgem após os primeiros centímetros decapados. Na foto 24 após a supressão de $10 \mathrm{~cm}$ de profundidade as manchas negras se tornam mais evidentes. Essas manchas, provavelmente, são testemunhos pós deposicionais da recomposição de matéria orgânica pelas águas da represa UHE-Marimbondo

Foto 24 - Nota-se nas circunferências pretas as áreas de maior ocorrência das manchas enegrecidas pela decomposição de matéria orgânica pós deposicional (Quadras A1 e A2 Nível 1). A seta preta indica área de nascente com suas adjacencias encharcadas. Ao fundo a represa da UHEMarimbondo.

Foto 25 - Nível 2 Quadra A1. Fragmentos de parede, borda e base de um mesmo pote. Notou-se que no nível 2 as cerâmicas se tornaram menos fragmentadas

Foto 26 - Nível 2 Quadra A1. Reconstituição de pote cerâmico

Foto 27 - Supressão do Nível 2 das Quadras C1, B1, A1 e A2. A seta preta indica um bloco testemunho localizado na quadra $\mathrm{C} 1$. Ao fundo o terreno encharcado e a represa da UHE-Marimbondo

Foto 28 - Paisagem de entorno da área de escavação 1. A seta preta indica as quadras de escavação, a seta azul a nascente e seu canal até o Córrego Menino Jesus e o círculo vermelho o terreno encharcado. Nota-se ao fundo a vertente que assenta o sítio em apreço e seus recursos naturais. Foto tirada da margem direita

Foto 29 - A seta preta indica a área de escavação 1, a seta vermelha indica 180 a área de escavação 2, a seta verde indica as águas represadas do Córrego Menino Jesus, a seta azul indica o curso do Rio Grande e a seta amarela a margem direita do Córrego em apreço

Fotos 30 e 31 - Reconstituição do conjunto 1. Vaso esférico ovaloide. Sítio Arqueológico Menino Jesus, município de Icém, SP.

Fotos 32 e 33 - Fragmento de fuso de cerâmica do Sítio Arqueológico Menino Jesus, Município de Icém, SP.

Fotos 34 e 35 - Bordas cerâmica de vasilha dupla e borda com incisão do Sítio Arqueológico Menino Jesus, Município de Icém, SP. 
Foto 36 - Reconstituição de decoração pintada, presente em fragmento de cerâmica. Sítio Arqueológico Menino Jesus, município de Icém, SP.

Foto 37 - Reconstituição de decoração pintada, presente em fragmento de cerâmica. Sítio Arqueológico Menino Jesus, município de Icém, SP.

Foto 38 - Reconstituição de decoração pintada, presente em fragmento de cerâmica. Sítio Arqueológico Menino Jesus, município de Icém, SP.

Foto 39 - Reconstituição de decoração pintada, presente em fragmento de cerâmica. Sítio Arqueológico Menino Jesus, município de Icém, SP.

Foto 40 - Reconstituição do decantador de vinho artesanal

Fotos 41 e 42 - Moeda do Sítio Arqueológico Santa Filomena.

Fotos 43 e 44 - Modelo de moeda do início do século XIX, similar a encontrada no Sítio Santa Filomena. 


\section{LISTA DE TABELAS}

Tabela 1 - Frequência de matérias-primas identificadas no Sítio Barra de 151 Ouro. Paulo de Faria, SP.

Tabela 2 - Categorias de materiais classificados para o Sítio Barra de Ouro, Paulo de Faria, SP.

Tabela 3 - Frequência de suportes identificados no Sítio Barra de Ouro, Paulo de Faria, SP.

Tabela 4 - Classe de Peças Cerâmicas identificados no Sítio Barra de Ouro,

Paulo de Faria, SP.

Tabela 5 - Classe de Peças Cerâmicas identificados no Sítio Porto Velho I,

Orindiúva, SP.

Tabela 6 - Classe de Peças Cerâmicas identificados no Sítio Porto Velho II, Orindiúva, SP.

Tabela 7 - Levantamento florístico na área do sítio Menino Jesus e de seu entorno.

Tabela 8 - Georreferenciamento das Matérias Primas adjacentes ao Sítio

Menino Jesus

Tabela 9 - Frequência das categorias identificadas. Sítio Arqueológico Menino Jesus. Icém - SP.

Tabela 10 - Frequência de matérias-primas identificadas. Sítio Arqueológico Menino Jesus. Icém - SP.

Tabela 11 - Frequência de Suportes identificados. Sítio Arqueológico

Menino Jesus. Icém - SP.

Tabela 12 - Categorias dos fragmentos cerâmicos do Sítio Arqueológico Menino Jesus.

Tabela 13 - Tipos de Antiplástico do Sítio Arqueológico Menino Jesus.

Tabela 14 - Tratamento de superfície dos fragmentos cerâmicos do Sítio Arqueológico Menino Jesus.

Tabela 15 - Características de emissão de moedas nos anos de 1825 a 1829. 


\section{SUMÁRIO}

$\begin{array}{ll}\text { INTRODUÇÃO } & 21\end{array}$

CAPÍTULO 1 26

ARQUEOLOGIA DA PAISAGEM: UMA ABORDAGEM

1.1. Paisagem, paisagens e sua inserção na arqueologia 27

1.2. Arqueologia da Paisagem: definição e linhas de pesquisa 32

1.2.1. História de Formação

1.2.2. Arqueologia dos Assentamentos 34

1.2.3. Arqueologia Processual $\quad 35$

1.2.4. Arqueologia Comportamental 38

1.2.5. Arqueologia Pós Processual 41

1.3. Arqueologia da Paisagem: escalas de trabalho 44

1.3.1. Escala espacial 44

1.3.2. Escala temporal e cenários de paisagem 47

1.3.3. Escala comportamental 49

1.4. Cartografia da paisagem arqueológica $\quad 50$

1.5. Processos deposicionais e pós-deposicionais 51

1.6. Cultura material na perspectiva de habitação

$\begin{array}{ll}\text { 1.6.1. As Cadeias de Atividades } & 60\end{array}$

1.6.2. Identificando a produção e distribuição dos fragmentos de cerâmica 64 no contexto arqueológico

1.6.3. Identificando a produção e distribuição dos líticos lascados e polidos $\quad 68$

CAPÍTULO 2

\section{A OCUPAÇÃO INDÍGENA REGIONAL: ELEMENTOS PARA UMA SÍNTESE HISTÓRICA COMPARATIVA}

2.1. Contexto Arqueológico Extrarregional 73

2.1.1. A Região Centro-Oeste 73

2.1.2. O Vale do Rio Paranaíba e do Rio Grande (margem mineira) 83

2.2. As Áreas Circunjacentes ao CAR no estado de São Paulo 84

2.2.1. Médio-Baixo Tietê

2.2.2. Bacia do Rio Mogi-Guaçu e Pardo 87

2.3. Contexto Arqueológico Regional 93

2.4. Organização socioespacial indígena: trajetórias dos Kayapó 110 Meridional entre os séculos XVIII ao XX

2.4.1. Quem são os Kayapó Meridional? 110

2.4.2. Qual era seu território e em que época histórica foram retratados? 111

2.4.3. Como eram suas aldeias e aldeamentos? 119 
2.4.4. Considerações sobre os aspectos socioespaciais dos Kayapó

Meridional

CAPÍTULO 3

128

\section{O CONTEXTO DOS SÍTIOS ARQUEOLÓGICOS}

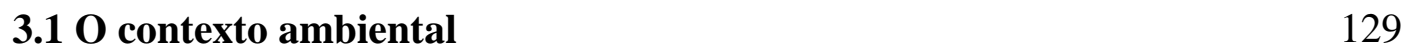

3.1.1. Clima 130

3.1.2 Topografia, geologia e pedologia 131

3.1.3 Vegetação e fauna 132

3.2. Colonização e transformação da paisagem 138

3.2.1. Agricultura de subsistência, a lavoura de algodão e a pecuária 138

3.2.2. O Setor Sucroalcooleiro 140

3.2.3. O Setor Energético (Hidroelétrico) 142

3.3. Programa de Salvamento Arqueológico 143

3.3.1. Resgate arqueológico e resultados da pesquisa 145

3.3.2. O sítio arqueológico Barra de Ouro 146

3.3.2.1. O trabalho de campo 146

3.3.2.2. Quadro geoambiental e pós-deposicional 148

3.3.2.3. Análise da coleção arqueológica 151

3.3.3. O Sítio Arqueológico Porto Velho I 154

3.3.3.1. O trabalho de campo 154

3.3.3.2. Quadro geoambiental e pós-deposicional 157

3.3.3.3. Análise da coleção arqueológica 160

3.3.4. O Sítio Arqueológico Porto Velho II 162

3.3.4.1. O Trabalho de campo 162

3.3.4.2. Quadro geoambiental e pós-deposicional 164

3.3.4.3. Análise da coleção arqueológica 167

3.3.5. O Sítio Arqueológico Menino Jesus 168

3.3.5.1. O Trabalho de campo 168

3.3.5.2. Quadro geoambiental e pós-deposicional 188

3.3.5.3. Análise da coleção arqueológica 193

3.3.5.4. Os materiais arqueológicos e a análise intrassítio 204

3.3.6. O Sítio Arqueológico Santa Filomena 214

3.3.6.1. Os trabalhos de campo $\quad 214$

3.3.6.2. Os relatos orais $\quad 219$

3.3.6.3. Histórico da vila de São Vicente do Talhadão 223

CAPÍTULO 4

SISTEMAS REGIONAIS DE POVOAMENTO IDENTIFICADOS NO CAR

4.1. Sistema de Povoamento Regional Aratu-Sapucaí 229

4.2. Sistema de Povoamento Regional Guarani 235

$\begin{array}{ll}\text { 4.3. Os aldeamentos regionais } & 238\end{array}$

CONSIDERAÇÕES FINAIS 242 
REFERÊNCIAS

ANEXOS 


\section{RESUMO}

Esta pesquisa apresenta alguns resultados do trabalho realizado com enfoque na arqueologia da paisagem em sítios arqueológicos localizados na Bacia Hidrográfica do Rio Turvo-Grande. Os procedimentos de campo foram iniciados no ano de 2011 e finalizados no ano de 2014, permitindo-nos avaliar o tipo e a intensidade de materiais arqueológicos, sua distribuição na paisagem, os aspectos geoambientais relevantes para a ocupação pretérita e os processos de formação atuantes nesses registros.

Os dados colhidos em campo foram compilados em linguagem cartográfica,o que permitiu gerar informações espaciais dos sítios arqueológicos, bem como compreender sua possível relação com os geoindicadores locais. Os materiais arqueológicos recolhidos foram analisados em laboratório, levantando questões importantes sobre a sua produção, o seu uso e a sua espacialidade intrassítio.

Os sítios arqueológicos trabalhados no âmbito dessa pesquisa foram correlacionados ao contexto arqueológico regional. A análise multiescalar e multidimensional desse contexto permitiu identificar alguns padrões socioespaciais que auxiliaram na compreensão do processo de habitar e transformar às paisagens do norte do estado de São Paulo.

Palavras-Chave: Arqueologia da paisagem; Contexto arqueológico regional; Bacia do rio Turvo-Grande, Sistema Regional de Povoamento, Norte do estado de São Paulo. 
INTRODUÇÃO 
O delineamento desta pesquisa de doutorado iniciou-se no ano de 2011, quando ocorreu o Projeto de Resgate Arqueológico e o Programa de Educação Patrimonial para a área de cinco sítios arqueológicos - dois no Município de Paulo de Faria, dois no Município de Orindiúva e um no Município de Icém, SP, coordenado pela profa. Dra. Neide Barrocá Faccio (Figura 1).

Figura 1: Localização dos sítios arqueológicos nos Municípios de Paulo de Faria, Orindiúva e Icém.

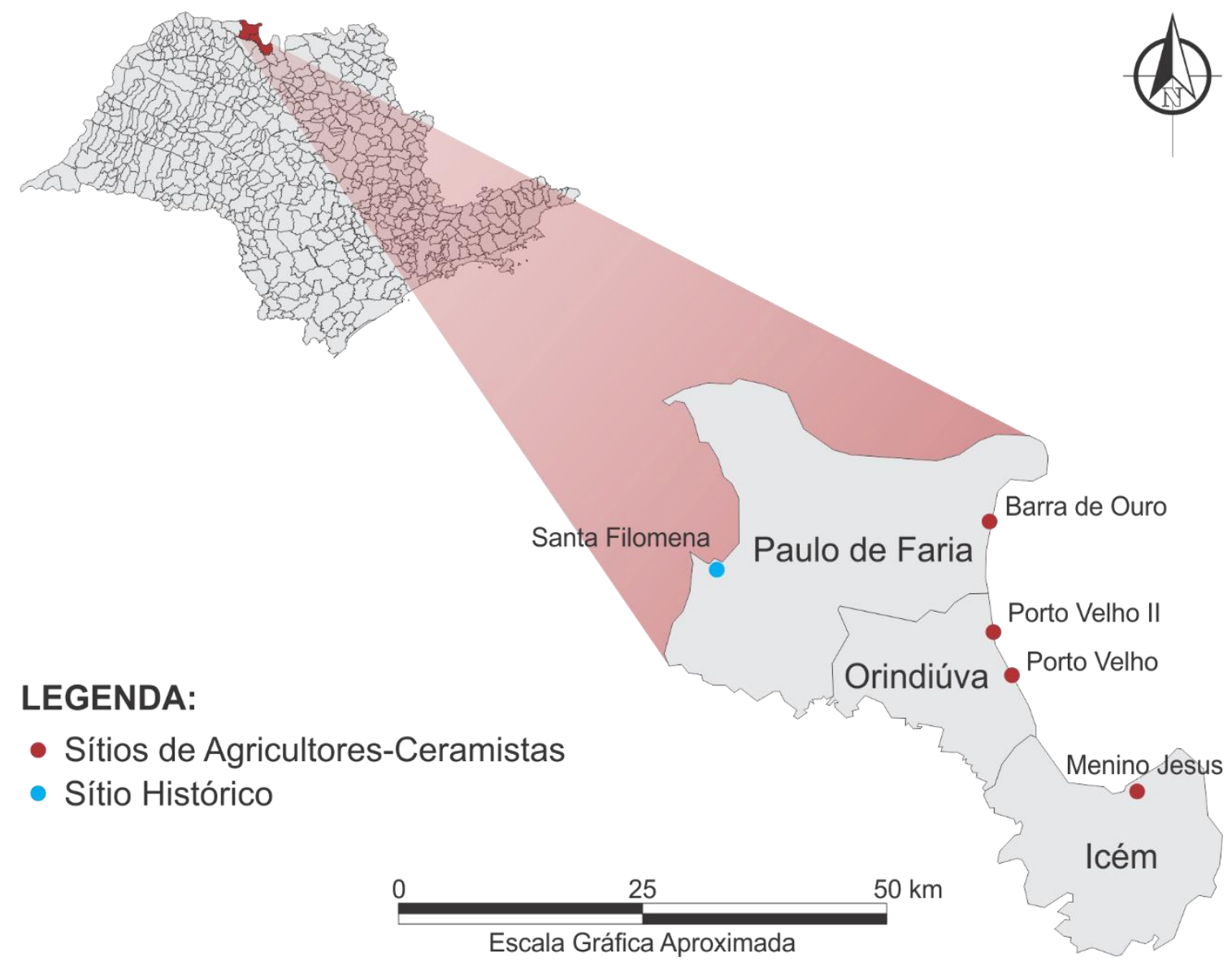

Fonte: adaptado de IBGE (2014).

Durante a realização dos trabalhos de pesquisa, foram avaliadas as áreas de cinco sítios arqueológicos. Os sítios estão relacionados a quatro ocupações indígenas précoloniais e uma histórica. O resgate desses sítios constituiu-se em procedimento de pesquisa necessário à mitigação de possíveis impactos ao patrimônio arqueológico regional, decorrente da implantação do empreendimento em questão.

Os dados primários de campo e laboratório, gerados pelo estudo dos sítios arqueológicos, possibilitaram caracterizar essas ocupações humanas pretéritas e contextualizá-las aos dados arqueológicos e etno-históricos regionais. 
No período entre 2011 e 2013, iniciou-se a revisão da literatura sobre a ocupação humana no norte do estado de São Paulo, bem como sobre as linhas de pesquisas da arqueologia que pudessem trabalhar esses dados de forma coerente e satisfatória. Dividiuse essa trajetória em dois caminhos paralelos que ao final tornaram-se, também, complementares.

Ao concluir o primeiro caminho, propôs-se uma análise que integrasse os dados levantados em campo, laboratório e revisão bibliográfica referente à arqueologia e etnohistória regional com os aspectos da paisagem, sob a ótica da arqueologia da paisagem. Nesse contexto de análise, deu-se ênfase à distribuição de vestígios arqueológicos na paisagem (ARAUJO, 2001), sua relação com o meio físico-biótico, recomposição dos principais traços da paisagem à época das ocupações, enfoques etno-históricos e procedimentos e técnicas de datação para inserção cronológica dessas ocupações humanas no passado (MORAIS, 1999; 1999-2000; 2000).

Como mediadora, a paisagem dentro da ótica da arqueologia da paisagem rompe com o foco de análise sobre o sítio arqueológico, indicando um caminho multiescalar e multidimensional (HOLLENBACK, 2010). Multiescalar, no sentido de uma análise espacial, temporal e comportamental. Trabalhando com as escalas, o arqueólogo pode aplicar diversos níveis de articulação entre esses três fenômenos (BOADO, 1997). Multidimensional, porque permitiu considerar a paisagem como formal, relacional e histórica. A dimensão formal implicou no estudo da relação e uso dos elementos de uma paisagem por uma determinada comunidade. A dimensão relacional considerou a organização e a conexão dos elementos da paisagem por meio do movimento das pessoas e das informações. Finalmente, a dimensão histórica considerou a sequência de ocupações relacionadas a nossa área de pesquisa (HOLLENBACK, 2010).

O segundo caminho possibilitou a delimitação da área de estudo. Nessa área foi levantada uma gama de dados que esboçaram um quadro comparativo e complementar ao levantamento dos sítios arqueológicos no âmbito do projeto de resgate mencionado. Neste primeiro momento da revisão bibliográfica, percebeu-se que havia um número baixo de pesquisas arqueológicas sistemáticas publicadas, sobre a região norte do estado de São Paulo. Os dados oferecidos consideravam esta região como palco de ocupações diferenciadas, refletindo contexto extrarregional com influência da "tradição tupiguarani" e "tradição aratu-sapucaí" (AFONSO; MORAES, 2007; FERNANDES, 2011; RODRIGUES, 2008). 
Essa revisão também levantou relatórios de pesquisas acondicionados no IPHAN-SP. Eles forneceram informações básicas sobre sítios arqueológicos ceramistas como: tipo de material encontrado, localização do sítio, datação absoluta e as suas tradições arqueológicas. Ao final deste trajeto, plotamos estes sítios em mapa e delimitamos nossa área de pesquisa.

O próximo passo foi justificar a relevância do estudo proposto: por que estudar sítios arqueológicos sob a ótica da arqueologia da paisagem? Ponderou-se que um dos pontos positivos desta perspectiva foi o de testar algumas ferramentas de análise sobre a ocupação humana em sua esfera sincrônica e diacrônica em determinada região. Ou seja, executar um estudo que privilegiasse aspectos multiescalares e multidimensionais do processo de habitar e transformar uma paisagem. Um segundo ponto positivo foi que, até meados dos anos de 2014, ainda não haviam sido feitos estudos sistemáticos em arqueologia da paisagem na região norte do estado de São Paulo.

Pensar a justificativa para a construção dessa tese fez com que surgisse um problema de pesquisa basilar para sua fundamentação: como aconteceu o processo de ocupação e habitação do norte do estado de São Paulo, desde o período pré-colonial até as primeiras incursões colonizadoras e como a paisagem foi sendo apropriada e transformada por essas sucessivas ocupações?

A escolha do problema de pesquisa levou em conta estes fatores imprescindíveis:

1- O problema de pesquisa é original?

2- O problema de pesquisa é relevante e interessante para a disciplina arqueológica ou a arqueologia brasileira?

3- Há ferramentas adequadas para executar tal pesquisa?

As respostas confirmariam a necessidade da pesquisa:

1- O problema de pesquisa é original, considerando a região de estudo.

2- Oferece dados importantes para o estudo dos povoamentos regionais.

3- Existe a possibilidade de executar e manejar de forma adequada as ferramentas para essa pesquisa.

A partir dessas conclusões, foi levantada a seguinte hipótese: A arqueologia da paisagem e o uso de suas escalas e dimensões de análise possibilitam a compreensão do processo de ocupação, apropriação e interação entre grupos humanos e a paisagem no transcorrer do tempo.

Assim, a presente tese organizou-se com os seguintes objetivos, que se desdobraram em capítulos específicos de trabalho: 
- Apresentar o conceito de paisagem, esboçando sua interface com a arqueologia da paisagem, expondo suas linhas de pesquisa e desvelando seus pontos tangenciais para uma análise arqueológica em âmbito regional (Capítulo 1);

- Investigar na bibliografia disponível os documentos que reportaram aos sítios arqueológicos regionais, extrarregionais, bem como localizar nos documentos históricos as características socioespaciais dos grupos humanos que habitaram nossa área de pesquisa e áreas adjacentes no período colonial (Capítulo 2);

- Apresentar a execução do trabalho de campo na área dos sítios arqueológicos, a análise das coleções de materiais arqueológicos resgatadas e o mapeamento georreferenciado desses materiais (Capítulo 3);

- Conectar as linhas de pesquisas, as informações regionais sobre arqueologia / etno-história e os dados levantados sobre os sítios arqueológicos resgatados no âmbito desta tese, estabelecendo um modelo de ocupação regional para o norte do estado de São Paulo (Capítulo 4).

Nas considerações finais, apresento a síntese acerca do conhecimento produzido nesta etapa de trabalho acadêmico. 
CAPÍTULO 1 ARQUEOLOGIA DA PAISAGEM: UMA ABORDAGEM 


\subsection{Paisagem, paisagens e sua inserção na arqueologia}

A origem da palavra "paisagem" parece remeter a duas perspectivas originais que ao longo do tempo foram se diversificando em conteúdos e significados. A primeira perspectiva seria estético-fenomenológica, correspondendo à representação pictórica. A segunda, a partir de uma perspectiva geopolítica, designa uma unidade territorial (VITTE, 2007).

Consta nos dicionários de língua francesa do século XVI e XVII que o termo "paisagem" foi aplicado aos quadros que representassem uma região, uma pintura sobre tela ou uma reprodução pictórica de uma vista, normalmente como fundo de um quadro ${ }^{1}$. Em síntese, nessa época a paisagem foi considerada como um produto da arte de representar, em um enquadramento, uma dada realidade geográfica (ALVES, 2001).

A pintura da paisagem desenvolveu-se por toda a Europa, desde Flandres no século XV, passando por Holanda, Inglaterra, até a França no século XIX. A partir do século XX, houve mudanças na percepção e representação da paisagem, que começaram com o movimento impressionista, as representações abstratas, atingindo um ápice com os surrealistas, Assim, o conceito de paisagem evoluiu de uma representação naturalista do espaço geográfico, para uma metáfora da representação dos mundos da mente, da imaginação e dos ideais. A paisagem gradativamente perde seu caráter exterior, de pano de fundo, de um cenário, passando a ser compreendida na arte como uma experiência e um envolvimento das pessoas com o mundo que as permeia (Ibidem, 2001).

Uma segunda perspectiva do termo "paisagem" é compreendida por sua própria etimologia. O vocábulo paisagem está ligado a pays no francês, remetendo ao sentido de região, território e nação. Na língua inglesa, o termo landscape é derivado de landscip que, no século XVI, representava a organização dos campos. No holandês, landschap significa uma unidade de ocupação humana ou uma jurisdição. Dessa forma, o termo paisagem, em sua essência, encerra uma conotação espacial (pays, land) que abrange uma unidade territorial onde se desenvolve a vida de comunidades humanas (VITTE, 2007).

\footnotetext{
${ }^{1}$ Este ideal de paisagem, como um pano de fundo para a vida social, pode ter ressoado no projeto europeu de colonização das Américas. Como salienta Oliver (2010), o vazio pictográfico da paisagem se revelou como discurso colonial implícito que ajudou a legitimar a apropriação das terras e das florestas. A caricatura que o colonizador fez da natureza intocável causou uma espécie de miopia cultural em relação às práticas sociais dos nativos para com seu meio, resultando nas constantes práticas de usurpação das terras indígenas, transformando-as em propriedades de direito colonial.
} 
Neste aspecto, "paisagem" se aproxima de "cultura", no sentido estrito do termo. Cultura deriva da palavra colo $^{2}$, significando ocupar, trabalhar e cultivar a terra (BOSI, 1993); o que, a meu ver, implica em organização socioespacial, assim como paisagem. Mesmo ilustrada como pano de fundo de um cenário bucólico europeu, o conceito de paisagem já nasce com os pressupostos relacionais entre sociedade e ambiente, onde as relações de poder já são explícitas e ativas na organização da terra.

Em geografia, o objetivo do estudo da paisagem foi o de produzir uma imagem sintética, na qual cultura e natureza formariam um conjunto integrado, articulado e espacialmente diferenciado na superfície do planeta (VITTE, 2007).

No século XIX, Humboldt encontra na paisagem uma forma de articular o que se apresentava de maneira desconexa e contraposta: “[...] números e descrição poética, fisionomia e estética da paisagem; razão e sentimento; empírico e transcendental" [...] "A paisagem lhe permite, desse modo, não só a consideração dos elementos da natureza em plena relação, mas também a do papel criativo do homem na própria construção destes elementos e, sobretudo, na sua representação" (VITTE; SILVEIRA, 2010).

Esta paisagem humboltiana dos primórdios da geografia é facilmente encontrada em seu Quadros de Natureza. Vejamos um exemplo:

Tudo quanto tende a reproduzir a verdade da natureza, dá nova vida à linguagem, quer se trate de descrever a impressão sensível produzida em nós pelo mundo exterior, quer os nossos sentimentos íntimos e as profundidades em que se agita o nosso pensamento.

A investigação constante desta verdade é o fim de toda descrição que tem por objeto a natureza. É preciso manter incessantemente essa tendência - ou para se compenetrar melhor dos fenômenos, ou para escolher, ao pintá-los, a expressão característica. O meio mais apropriado de realizar esse fim consiste em que o observador, aquele que sentiu pessoalmente a impressão, a conte singelamente, e circunscreva e particularize o lugar ou as circunstâncias a que se liga a narração (HUMBOLDT, 1957, p. 260).

Nesta perspectiva de análise, o sujeito e sua representação do ambiente não se escondem em exames frios e quantitativos. Ao contrário, o observador é o ativo na compreensão dos fenômenos e a sua narrativa assume papel central na construção da paisagem.

\footnotetext{
${ }^{2}$ Assim como as palavras "colônia" e "colonização".
} 
Na leitura de Quadros de Natureza, Humboldt foi além da descrição geográfica; por meio de uma narrativa proso - poética procurou harmonizar a subjetividade e a objetividade, literalmente pintou com as palavras verdadeiros quadros de natureza, que longe de serem estáticos, reproduzem um esforço pictórico de desenhar com as palavras um cenário que envolve o homem, a botânica, a geologia e a zoologia.

A paisagem foi capaz de fornecer unidade e identidade à geografia num contexto de afirmação da disciplina. No entanto, a paisagem no decorrer dos anos trouxe novas acepções fundadas em diversas matrizes epistemológicas, apresentando, simultaneamente, as várias dimensões que cada matriz epistemológica privilegia: 1- uma dimensão morfológica, ou seja, das formas criadas pela natureza e pela ação humana, 2uma dimensão funcional, apresentando relações entre as suas diversas partes, 3- uma dimensão histórica, como produto da ação humana ao longo do tempo e 4- uma dimensão simbólica, portadora de significados, valores, mitos, crenças etc. (LOBATO CORRÊA; ROSENDAHL, 2004).

Em 1925, o ilustre geógrafo norte-americano Carl Sauer publica seu ensaio metodológico intitulado Morfologia da Paisagem. Nessa obra, Sauer define o conteúdo de uma paisagem como sendo as qualidades físicas de uma área que são significativas para o homem e suas formas de uso, em termos de seu sustento físico e de fatores da cultura humana (SAUER, 2006).

A paisagem, em seu ponto de vista, poderia ser dividida na paisagem natural, englobando cinco elementos como o clima, a superfície ou a forma do terreno, o solo, a drenagem das águas e as formas minerais, e na paisagem cultural, caracterizada pela transformação da paisagem natural pelo trabalho do homem. A junção entre as duas esferas se daria pela cultura como um agente transformador. Assim, "sob a influência de uma dada cultura, por si só mudando ao longo do tempo, a paisagem se vê sujeita a mudança, passando por fases, a alcançar provavelmente o fim de seu ciclo de desenvolvimento" (SAUER, 2006, p.14). Com a introdução de uma cultura externa, "se estabelece um rejuvenescimento da paisagem cultural, ou uma nova paisagem cultural é sobreposta aos remanescentes da outra anterior" (Ibidem, 2006, p.14).

Sauer (2006) define a paisagem natural como um "habitat complexo", com uma somatória de entidades físicas e biológicas que em combinação diferente resultaria nas diversas formas de uma paisagem. Essa morfologia da paisagem natural era incorporada pela morfologia cultural, onde suas formas são todas obras do homem; são as marcas do homem na paisagem. 
Sauer ([1925] 2006) funda em geografia, as bases dos estudos morfológicos e históricos sobre a paisagem, separando a esfera natural da esfera cultural, enfatizando a ação humana na transformação da paisagem, rompendo, assim, com o paradigma do determinismo ambiental que dominava a geografia norte-americana naquela época (MATHEWSON; SEEMANN, 2008).

A noção dada por Sauer de que a paisagem do presente é resultado da consequência histórica da interação entre o cultural e o ambiental (Ibidem, 2008) iria influenciar anos mais tarde duas vertentes importantes para a compreensão da paisagem em arqueologia: 1- a ecologia histórica e 2- a arqueologia da paisagem.

Em ecologia histórica, o conceito de paisagem desenvolveu-se em termos das "relações históricas dadas entre certos grupos de pessoas e ambientes definidos, através do tempo, frequentemente com um conceito de tempo profundo, ou la longue durée" (BALEE, 2008, p.11).

A paisagem que enfatizava um caráter morfológico na geografia de Sauer, divididas entre duas esferas, a natural e a cultural, passa a ser entendida como uma entidade histórica, com características tanto espaciais como temporais, modificadas por atividade humana, que pode ser percebida por meio do comportamento e padrões de ações, chamadas de cultura (BALEE; ERICKSON, 2006).

Nesta perspectiva, o conceito de "cultura" me parece inerente ao conceito de paisagem e vice e versa. Etimologicamente falando, não há paisagem sem organização cultural, assim como, não há cultura (colo) sem a organização da terra (land). Para explicitar melhor a questão, definimos neste trabalho que cultura resulta no "conjunto das práticas, das técnicas, dos símbolos e dos valores que se devem transmitir às novas gerações para garantir a reprodução de um estado de coexistência social" (BOSI, 1993). A cultura é incorporada à terra, por meio de suas esferas econômicas e simbólicas, acionando mecanismos de memória e transmissão de conhecimentos. Para que a cultura se organize dentro de uma paisagem, é necessário que um conjunto de símbolos ${ }^{3}$ funcionem como sintetizadores da visão de mundo de tal sociedade, formalizando suas crenças e seus valores sobre a materialidade da terra (GEERTZ, 1989).

A paisagem na ecologia histórica torna-se uma unidade multiescalar, diacrônica e holística de estudo e análise, onde a cultura é fisicamente incorporada e inscrita na

\footnotetext{
${ }^{3}$ Símbolos que podem ser expressos por meio de códigos visuais, práticas discursivas ou nos elementos da paisagem (BONNEMAISON, 2002; GEERTZ, 1989).
} 
paisagem como padrões não aleatórios, muitas vezes, um palimpsesto de habitação contínua e descontínua por povos passados e presentes (Ibidem, 2006).

Nessa mesma perspectiva, a arqueologia da paisagem começou a entender "paisagem" como um fenômeno em constantes mudanças, um contínuo de processos de aquisição e perda de elementos e significados. Assim, torna-se vital entender o processo de formação e história de vida de paisagens. O fenômeno arqueológico de uma paisagem (objetos, estruturas, sítios etc.) torna-se parte da paisagem presente e influencia o comportamento e as atividades de pessoas em tempos posteriores. Assim, a arqueologia da paisagem procura entender esse contexto em suas várias escalas de estudo e de suas dimensões de análise (HOLLENBACK, 2010).

Nota-se que a distinção básica entre paisagens culturais e naturais, implícita muitas vezes nos estudos de paisagem após os trabalhos de Sauer, foi reduzida nos estudos de ecologia histórica e arqueologia da paisagem. Isso porque as paisagens naturais que eram equiparadas a ambientes não adulterados, ou cujas propriedades eram minimamente impactadas pelas atividades humanas, paulatinamente foram sendo deslustradas. Reconheceu-se o envolvimento intenso de atividades humanas praticamente em todos os lugares onde as pessoas habitaram. Por sua vez, as paisagens culturais estão sendo interpretadas como incorporações dentro de redes ecológicas complexas, que envolvem interações de muitos componentes bióticos e abióticos culturalmente mediados (HEILEN, 2005).

Sauer (2004) procurava compreender a paisagem cultural como "as marcas do homem na paisagem", não se preocupando com "os costumes e crenças do homem" (SAUER, 2004, p.57). No entanto, nos últimos anos, os estudos de paisagem adquiriram um caráter associativo, pela virtude de integrar poder religioso, artístico e cultural ao seu elemento natural, na qual a evidência material nem sempre é o fator mais significante (HEAD, 2010).

Cosgrove (2004) tem particularmente direcionado a sua atenção para o entendimento do simbolismo da paisagem representado por uma visão de mundo que se instala da sociedade ao espaço e do espaço à sociedade. Acrescenta que todas as paisagens possuem significados simbólicos porque são produto da apropriação e transformação do meio pelo homem. Para o autor, a compreensão das expressões impressas por uma cultura na paisagem necessita de um conhecimento da "linguagem" empregada, ou seja, dos símbolos e de seus significados em determinada cultura. 
A apropriação simbólica do mundo, ou em outra escala, da paisagem, por determinada cultura, fortalece o grupo social em sua identidade, trazendo sua carga simbólica e humanizando a paisagem e seus elementos. Tornam rochedos, bosques, caminhos, rios etc em verdadeiros "geossímbolos", ou seja, são as expressões terrestres de mitos, fontes de poderes cósmicos e os fundamentos geográficos de sua organização social (BONNEMAISON, 2002).

As linhas escritas sobre a paisagem, ou melhor dizendo - as paisagens procuraram de forma geral delinear o caminho que esse conceito percorreu no tempo e nas suas dimensões de análise. Em um primeiro momento, dentro de um movimento romântico alemão, a paisagem de Humboldt nos impulsionava a entendê-la por uma narrativa proso - poética, onde o observador transcendeu sua posição de sujeito, incorporando à paisagem seu valor estético e fenomenológico.

Em Sauer, a paisagem é dicotomizada em duas esferas - a natural, como um habitat; e a cultural, como a intervenção humana nesse habitat. Essa relação entre as duas esferas estabelecidas pela cultura interagia no decorrer do tempo, formando uma história de vida. Essa concepção histórica da paisagem foi apropriada pela ecologia histórica e a arqueologia da paisagem que, em seus esforços, procuraram atenuar as disjunções entre o natural e o cultural, como apresentado por Sauer. Nos últimos anos, o estudo da paisagem morfológica, funcional e histórica vem sendo complementado por uma análise fundada no simbolismo, para o qual decodificar seu significado vem se tornando uma tarefa transdisciplinar.

A inserção da paisagem na arqueologia, nas últimas décadas, indica o desenvolvimento das pesquisas em arqueologia da paisagem em diversas direções e na proliferação de suas perspectivas. A seguir, apresentaremos uma síntese de como a arqueologia da paisagem foi sendo construída teoricamente, apontando suas dimensões e escalas de análise.

\subsection{Arqueologia da Paisagem: definição e linhas de pesquisa}

A arqueologia da paisagem possui raízes e bases nas várias dimensões de análise da paisagem. Por conta desta característica, seu entendimento também não é único e seus métodos de pesquisa são bastante ramificados. A própria síntese da arqueologia da paisagem só pode ser confeccionada a partir do exame de sua construção teórica, explorando sua história de formação, suas linhas de pesquisa, suas escalas de trabalho e 
dimensões de análise. Intentamos ao final deste percurso formular uma base teóricometodológica sólida, para captar e analisar as características da paisagem arqueológica em estudo.

\subsubsection{História de Formação}

Estudiosos do tema esclarecem que a arqueologia da paisagem não tem uma longa história de vida. Seu conceito foi formalizado pela primeira vez nos trabalhos acadêmicos, em meados da década de 1970. No ano de 1978, uma das principais revistas especializadas na temática arqueológica, a World Archaeology, dedica uma edição inteira ao tema Landscape Archaeology, focando suas análises nas dinâmicas socioambientais (DAVID; THOMAZ, 2008).

Os artigos, capítulos de livros e livros inteiros compilados nesta época eram dedicados à distribuição de artefatos/sítios em diferentes contextos ambientais, nas estratégias econômicas e suas dinâmicas inter-regionais, nas determinações econômicas do padrão de assentamento, na limitação ou expansão da produção agrícola, nos processos demográficos e na complexidade da organização social em configurações regionais particulares (Ibidem, 2008).

O novo conceito foi formulado para criar uma ligação entre o campo da arqueologia e o estudo da história da paisagem. Neste período, arqueólogos focaram nas relações entre humanos e ambientes do passado. As estratégias de levantamento de campo começaram a deslocar-se do sítio arqueológico para o off-site ou non-site, que seriam as áreas entre sítios com fundamental importância para a organização territorial dos sistemas culturais pretéritos. A grande revolução da arqueologia da paisagem, na década de 1970 e meados de 1980, foi o rompimento do foco no sítio, visando um caminho multiescalar (DAVID; THOMAZ, 2008; FLEMING, 2006; HOLLENBACK, 2010).

Por conta dos refinamentos metodológicos de campo, bem como das análises estatísticas que contemplaram as distribuições de materiais e sítios arqueológicos na paisagem, houve uma crescente aplicação e desenvolvimento de metodologias de pesquisas como a simulação e modelagem preditiva, tafonomia, geoarqueologia, bioarqueologia e paleoecologia (DAVID; THOMAZ, 2008).

Nesse contexto, as pesquisas arqueológicas procuraram sistematicamente acessar a padronização espacial do passado, por meio da distribuição de assentamentos e objetos 
culturais na paisagem. A arqueologia anglo-americana dos assentamentos ofereceu uma chave interpretativa para a incipiente arqueologia da paisagem (PARSONS, 1972).

Os conceitos norteadores para a arqueologia da paisagem eram o de "padrão de assentamento", que resumia as relações geográficas e fisiográficas de um grupo contemporâneo de sítios de uma só cultura. Enquanto o conceito de "sistema de assentamento" sintetizava as relações funcionais entre um grupo contemporâneo de sítios dentro de uma cultura e dentro de um padrão de assentamento (Ibidem, 1972).

A manipulação de dados quantitativos sobre a variabilidade do material arqueológico permitiu aos pesquisadores reconstruir locais multifuncionais e cenários de ocupação regional. Padrões e sistemas de assentamento foram conceitos que forneceram à arqueologia da paisagem informações valiosas sobre a dinâmica de grupos humanos pretéritos, bem como, a maneira pela qual essas sociedades utilizavam diferentes áreas de terra e distribuíam suas atividades na paisagem (LANE, 2008).

\subsubsection{Arqueologia dos Assentamentos}

A arqueologia dos assentamentos tem suas estruturas implantadas no funcionalismo. Tendo se desenvolvido na década de 1950, considerou os padrões arqueológicos inseridos nos assentamentos como um ponto de partida para a interpretação funcional de culturas arqueológicas (TRIGGER, 1992).

Segundo as ideias de Willey (1953), um dos pais da arqueologia de assentamentos, a necessidade destes estudos parte da crença de que a arqueologia poderia melhor colocarse na posição de contributa na interpretação dos aspectos organizacionais das sociedades pretéritas. Para tal empreendimento, eram necessários estudos de habitação e tipos de assentamentos focados em requisitos essenciais como cronologias dos sítios arqueológicas e mapeamento de suas distribuições espaciais.

Willey (1953) definiu o termo "padrão de assentamento" como a maneira pela qual o homem se dispõe sobre a paisagem em que vive. Refere-se, assim, às habitações, o seu arranjo e a disposição de outras construções relacionadas com a vida da comunidade. $\mathrm{O}$ estudo desses padrões refletiria no entendimento do ambiente natural, no "nível" de tecnologia em que os construtores operavam e nas instituições sociais e de controle que a cultura pretérita mantinha.

O autor ainda traçou os objetivos do estudo dos padrões de assentamento: 1descrever uma série de sítios pretéritos com referência à posição geográfica e cronológica; 
2- traçar uma reconstrução do desenvolvimento desses assentamentos com relação à função; 3- reconstruir as instituições culturais, na medida em que estas podem ser refletidas em configurações de assentamento e; 4- comparar a história do assentamento com outras regiões (WILLEY, 1953).

No contexto da arqueologia dos assentamentos fundada por Willey, os sítios passaram a ser vistos como redes, onde desempenhavam papéis distintos, embora complementares. Buscavam nos dados arqueológicos o acesso às relações sociais, como o funcionamento dos direitos econômicos, políticos e relacionamentos afetivos (TRIGGER, 1967).

Trigger (1967) formulou uma hierarquia de níveis básicos de análise dos assentamentos. Em um primeiro nível, estaria a estrutura individual; no segundo, o assentamento; e no terceiro, a distribuição dos assentamentos. As estruturas individuais refletiam as organizações familiares e, por meio de seu desenho e uso, poderia se apreender o tamanho das famílias, se nucleares ou extensas, bem como se haveria divisão de classes e especialização, dentro da estrutura de habitação e da comunidade. A distribuição espacial dessas comunidades poderia indicar hierarquias de governo, locais religiosos, comércio, defesa regional e setores administrativos.

Em síntese, a importância da investigação de padrão de assentamento para os arqueólogos foi sistematizar comportamentos sociais em níveis básicos de análise, dentro de uma perspectiva regional. Pontuam-se quatro objetivos inaugurados nessa proposta: 1a hierarquia de assentamentos e suas relações espaciais; 2- a estrutura social inferida por meio da hierarquia de assentamentos; 3- a relação dos assentamentos com as características geográficas, tais como a utilização topográfica, uso do solo, aproveitamento dos tipos de vegetação etc.; e 4- as mudanças através do tempo com vistas a providenciar e analisar materiais para generalização sobre o processo cultural (PARSONS, 1972).

A definição de padrões de assentamento forneceu aos arqueólogos uma ampla oportunidade de prosseguir nos estudos em questão. As relações entre pessoas, sociedades e as configurações ecológicas fundamentaram uma base epistemológica centrada no assentamento regional, refletindo o espírito científico da época, tendo a arqueologia se apropriado do positivismo lógico e de modelos econômicos neoclássicos (PATTERSON, 2008).

\subsubsection{Arqueologia Processual}


Enquanto os padrões de assentamento estariam centrados no estudo das relações geográficas entre os sítios e o ambiente envoltório; na década de 1970, o estudo de assentamento voltou-se para as relações funcionais dos sítios, intentando inferir sobre a tipologia de sítios e as atividades realizadas nestes locais (TRIGGER, 1992).

Nesta finalidade, foi determinante a análise dos artefatos e o papel desempenhado por eles nos sistemas sociais. O objetivo arqueológico na década de 1970, com o nascimento da Nova Arqueologia ou Arqueologia Processualista, foi reconstruir sistemas culturais com base nos aspectos técnico-econômicos, sociotécnicos e ideológicos dos artefatos (BINFORD, 1991).

A habilidade do arqueólogo à época era manipular quantitativamente dados para a reconstrução dos sistemas de assentamento. Acreditava-se que a variabilidade de atividades em diferentes sítios poderia ser compreendida por meio da análise da variabilidade estilística dos objetos arqueológicos em contexto intrassítio. Assim, uma distribuição diferencial de tipos de cerâmica, a exemplo, dentro de um sítio era fonte sugestiva para inferências sobre as funções ali executadas, padronizando e mapeando os locais multifuncionais de um determinado sítio e entre os sítios dispostos em uma região (PARSONS, 1972).

As distribuições dos materiais arqueológicos na paisagem eram reunidas em conjuntos (assemblages). Estes conjuntos eram definidos em termos de objetos recorrentes em um determinado tempo e lugar e que representavam a soma de atividades humanas e processos de transformação (REFREW; BAHN, 2008).

Com base no estudo do conjunto dos artefatos intrassítio e sua relação com outros conjuntos disponíveis na paisagem, Winters (1967) ponderou que dentro deste sistema de assentamento, o pesquisador deve possuir a habilidade de inferir a época do ano durante os quais diferentes tipos de sítios foram ocupados e as atividades que foram realizadas nestes locais. Em suma, a distribuição diferencial dos tipos de materiais arqueológicos dentro de um sítio sugeriria as funções ali executadas, possibilitando uma padronização geral de locais funcionais, multifuncionais e suas especificidades ambientais.

Binford (1982) estava interessado em entender a relação organizacional entre os lugares que, para ele, foram usados de formas diferentes durante a operação de um sistema passado. O "lugar", neste contexto, relacionava-se à topografia e servia de base para o homem do passado executar suas ações. A preocupação da arqueologia de Binford fixa- 
se no entendimento do padrão de sítio, tanto em frequência de ocupação em diferentes lugares, quanto entre os materiais arqueológicos inseridos nestes lugares.

Combinando análises intrassítio e inter-sítio, Binford (1982) oferece uma arqueologia voltada para o retrato sistemático e objetivo de culturas extintas. Compreende as ações humanas como "estratégias adaptativas" sobre a paisagem, o que pode ser entendido como uma tática social que gera variabilidade no registro arqueológico e que cria estabilidade dentro do sistema.

As estratégias adaptativas sobre a paisagem poderiam ser compreendidas em termos de "mobilidade", ou seja, a maneira como zonas econômicas ao redor dos campos residenciais são ajustadas em relação à distribuição de recursos. Esse fenômeno caracteriza-se pela interação entre as características de cada zona econômica e o grau da característica da mobilidade residencial dos grupos em estudo. Os grupos tendem a mover seus campos residenciais para lugares específicos pré-concebidos, com ótima congruência entre obtenção de comida, combustível e água (BINFORD, 1982).

Desenvolve-se assim, o entendimento da paisagem como uma região de subsistência sazonal, onde ocorre a mobilidade dos grupos em um ciclo anual, sendo construídos e ocupados diferentes tipos de sítios focados em atividades econômicas distintas e/ou complementares, que por sua vez, resultariam em um padrão de ocupação, bem como em uma sistematização de suas funções (Ibidem, 1982).

$\mathrm{O}$ estudo da paisagem por meio dos conceitos e temas desenvolvidos pela arqueologia processual possibilitou criar tipologias dos sítios arqueológicos. Desta forma, sítios arqueológicos que apresentam baixa densidade e variabilidade de material arqueológico, em alguns contextos, podem não se tratar de antigas habitações, mas, possivelmente, de locais de atividades específicas, como acampamentos sazonais, acampamentos noturnos, atividades de roça ou locais de caça e/ou coleta (BINFORD, 1982; FACCIO, 1998; NOELLI, 1993; WUST, 1990).

Por outro lado, sítios-habitações devem representar, por meio de sua densidade e variabilidade de artefatos, atividades múltiplas desenvolvidas no local, sempre em confluência com a paisagem em que se insere e que o circula. O modelo de ocupação seria baseado num padrão organizacional entre a paisagem, como fonte de recursos, e o sistema cultural vigente. Com base nesta equação, os locais de atividades específicas inserem-se dentro de um raio logístico de exploração ampla de recursos, que se conecta ou entrelaça-se entre eles e com o sítio-habitação, que assume caráter central nesta 
configuração. Este modelo se adequa melhor às estratégias de subsistência de grupos agricultores estabelecidos em aldeias (BINFORD, 1983; WUST, 1990).

Esquematicamente, a proposta de estudos regionais sobre sistemas de assentamento privilegia quatro camadas interdependentes, a saber: 1- os aspectos físicos e geográficos, 2- os aspectos sócio-culturais, 3- os aspectos funcionais e 4- os aspectos simbólicos.

Padrões e sistemas de assentamento, bem como suas configurações ambientais, foram um foco importante no desenvolvimento da arqueologia da paisagem, caracterizando o raciocínio lógico por detrás das estratégias de investigação das respostas humanas para suas necessidades biológicas, em configurações ambientais particulares (DAVID; THOMAZ, 2008).

\subsubsection{Arqueologia Comportamental}

A arqueologia comportamental começou a tomar forma na Universidade do Arizona, Estados Unidos, durante o apogeu do processualismo, na década de 1970. Esta abordagem procurou entender a relação entre o comportamento humano e a cultura material, no decorrer do tempo e do espaço e como essa relação se desdobrou na formação do registro arqueológico. Assim, os processos de formação do registro arqueológico tornaram-se o pilar dessa arqueologia (SCHIFFER, 2010).

A aproximação da arqueologia comportamental para o estudo da paisagem trouxe a essa esfera um quadro explícito para investigar o processo de formação do registro arqueológico no nível das interações entre pessoas e lugares, paisagens e territórios (HOLLENBACK, 2010).

O estudo de paisagens arqueológicas vistas pela ótica comportamental abrange abordagens que tratam da história de vida de uma paisagem, de seu contexto arqueológico e seu contexto sistêmico ${ }^{4}$, bem como do processo de formação do registro arqueológico (HEILEN, 2005; HOLLENBACK, 2010).

\footnotetext{
${ }^{4}$ Contexto sistêmico é a simplificação de uma série de atividades que um sistema cultural produz durante seu processo de atuação. O contexto arqueológico seria o resultado do processo de formação de um depósito remanescente deste sistema cultural pretérito (SCHIFFER, 2010). As teorias de médio alcance desenvolvidas pela arqueologia processual consistem em fazer inferências sobre o passado a partir de fatos contemporâneos, ou seja, como interpretamos fatos estáticos do passado (contexto arqueológico) tomando observações de processos dinâmicos (contexto sistêmico) (BINFORD, 1991).
} 
A história de vida de uma paisagem enfatiza questões como estabelecimento, manutenção e transformação destas manifestações espaciais. Tanto Heilen (2005) quanto Zedeño (1997) empregam esta abordagem de história de vida, argumentando tratar-se do estudo das páginas da história da terra e do uso de seus recursos, nas quais estes processos podem ser documentados por meio de sua escala espacial e temporal, como veremos adiante.

Cabe salientar que os processos envolvidos na formação de uma paisagem e sua história de vida não assumem uma estrutura linear, mas cíclica, onde os processos de estabelecimento e manutenção estão interligados. A fissão de um assentamento, por exemplo, pode gerar a exploração de novas paisagens, que por sua vez iniciará um processo de colonização, assentamento, expansão, consolidação e fissão. Esse processo pode ocorrer em áreas novas, nunca antes exploradas, colonizadas ou assentadas, ou pode ocorrer em áreas que nunca foram totalmente abandonadas, como terras ancestrais, aldeias e locais rituais (ZEDEÑO, 1997).

Estas terras podem ser reocupadas e/ou ressignificadas e são consideradas como lugares persistentes dentro de um território amplo. Antigas aldeias são reocupadas, locais ancestrais são visitados, ocupados temporariamente, santuários são mantidos limpos e cuidados etc. (Ibidem, 1997).

O processo cíclico de reocupação traz fortes implicações na configuração dos assentamentos e habitações. Traduzidos muitas vezes na expansão e contração das aldeias indígenas, este processo demonstra que a disposição das habitações está, em alguns casos, em lenta e contínua movimentação, gerando mudanças consideráveis no registro arqueológico que incorpora esses movimentos, misturando-se evidências materiais de tempos diferenciados (MOI, 2007; MORALES, 2007; SCHIFFER, 2010). O resultado desse processo sistêmico é o "superdimensionamento de área e população de um sítio, mascarando os padrões de organização espacial e de utilização interna dos assentamentos" (MORALES, 2007, p. 85).

Assim, em certas circunstâncias pode ocorrer um adensamento de vestígios arqueológicos, uniforme em alguns locais, e aleatório, em outros, refletindo em dois conjuntos de processos de formação distintos, em relação ao tempo e ao processo de expansão ou contração da aldeia (CARR, 1984). Por exemplo, aldeias pré-coloniais de 
grandes dimensões, apresentando numerosos núcleos de solos antropogênicos ${ }^{5}$ de tamanhos diferenciados e com distribuição espacial variada, podem ter sido produto de diversas ocupações cronologicamente distintas.

No entanto, outro processo pode entrar em voga na transformação de um assentamento, ou em outra escala, de uma paisagem. É o que Zedeño (1997) denominou "recuperação". O processo refere-se à reciclagem, aquisição, ou mesmo usurpação de um território anteriormente ocupado por outro grupo. Ocorre, assim, a posterior reutilização das modificações da paisagem deixadas por antigos ocupantes, ou seja, o processo de recuperação envolve o início da formação do território de uma sociedade onde outra sociedade residia anteriormente.

O processo de formação do registro arqueológico engloba diversos fatores que podem nos ajudar a entender o comportamento humano passado. Como visto nas linhas anteriores, a história de vida de uma paisagem tem uma relação de complementaridade entre processos arqueológicos e históricos (HEILEN, 2005; HOLLENBACK, 2010; SCHIFFER, 2010; ZEDEÑO, 1997).

A formação do registro arqueológico engloba uma constante confecção, utilização e reutilização de seus materiais, que sobreviveram e foram transformados de estado para estado, dentro do contexto sistêmico. Essa gama de objetos remanescentes do contexto sistêmico para o contexto arqueológico é chamada de deposição cultural. Essa família de processos diretamente responsáveis pelo depósito de materiais no ambiente é capaz de fornecer informações sobre o comportamento humano passado (SCHIFFER, 2010).

O comportamento humano do passado aconteceu em locais de atividades externos e internos ao assentamento e geraram materiais que foram deixados em locais, sem terem passado por atividade de descarte (refugo de fato), que foram depositados no mesmo contexto de sua utilização (refugo primário), transportados para lugares específicos de descarte (refugo secundário) ou transportados e usados em outras áreas de atividades ou assentamentos (conjunto de curadoria). Em princípio, os itens de refugo e curadoria devem somar um inventário completo sistêmico, mas deve-se considerar que, em alguns casos, artefatos são perdidos ao longo do caminho ou depositados em trilhas ou estradas formando o refugo de trânsito (Ibidem, 2010).

\footnotetext{
${ }^{5}$ É um tipo de macro-assinatura dos povos indígenas pré-coloniais, corrente nos sítios agricultores. Caracteriza-se por ser um corpo sedimentar remanescente de antigos solos de habitação e seu cinturão envoltório, depósitos de lixo, áreas de cocção de alimentos etc. (MORAIS, 2006, p.203)
} 
A arqueologia comportamental trouxe importantes avanços ao entendimento de paisagens e depósitos culturais em termos de análise de unidade de escala, modelo de história de vida e processo de formação. Fez a discriminação entre o contexto sistêmico no qual artefatos participam da cultura viva e o contexto arqueológico que se forma após o descarte e no qual os arqueólogos atualmente os encontram (JOYCE; POLLARD, 2010).

\subsubsection{Arqueologia Pós Processual}

O estudo da organização funcional da paisagem, originado na arqueologia dos assentamentos e aprimorado pela arqueologia processual e comportamental, utilizou uma abordagem baseada no método hipotético-dedutivo de raciocino ${ }^{6}$. Este processo de investigação dentro do campo arqueológico por meio de estudo de ocorrências visa alcançar o plano das generalizações, em lugar de uma investigação focada apenas nas características contextuais de cada sítio arqueológico. Assim, foram se confeccionando procedimentos, testes rigorosos e formulações de hipóteses prontas para orientar as pesquisas arqueológicas. A estandardização da cultura material em relação ao seu ambiente gerou explanações espaciais padronizadas, que muitas vezes sonegaram questões sociais e simbólicas sobre a paisagem (SHANKS; TILLEY, 1987; WHITELAW, 2004).

Os detalhes negligenciados pela arqueologia dos assentamentos e arqueologia processual/comportamental são agora tratados por outras correntes de pensamento arqueológico que começaram a surgir na década de 1980, portanto após a criação e desenvolvimento da arqueologia processualista.

Essas novas formas de pensar e analisar o objeto arqueológico enfatizam dimensões sócio simbólicas da paisagem, pela sua virtude de ser percebida, experienciada e contextualizada por pessoas. Para além das divisões clássicas entre ambiente e sociedade, as novas formas de análise da paisagem estão preocupadas em entender como a visão de mundo, cosmologia e a história social se materializam e são expressas nos planos de construções, assentamentos e na paisagem arqueológica em si (ASHMORE; KNAPP, 1999; LANE, 2008; PATTERSON, 2008).

\footnotetext{
${ }^{6}$ Este tipo de investigação foi desenvolvido por Popper dentro daquilo que ele chamou de racionalismo crítico. Nesta linha positivista de pensamento, Popper defende o caráter hipotético de todo conhecimento científico onde só se admite a prova empírica e tão somente após ela ter sido formulada. Busca-se uma unidade metodológica para a investigação de dados naturais e sociais, ambos sendo regidos por leis invariáveis (TRIVIÑOS, 1987).
} 
Para Hodder (1982), a concepção social, fundamentada neste tipo de análise arqueológica, destaca as dimensões simbólicas de práticas sociais, enfatizando os significados culturalmente específicos e variáveis da cultura material. Esta abordagem rompe com os padrões culturais reducionistas atribuídos a arqueologia processual.

Em escala mais ampla, a crítica destes autores à arqueologia da paisagem processualista é que a última considera a paisagem em termos utilitarista e funcional, como uma expressão impessoal de forças demográficas e econômicas, ignorando assim as múltiplas camadas de significado simbólico ou representação cultural que nela são depositadas (COSGROVE, 2004; INGOLD, 1993).

As discussões levantam a questão da construção e interpretação das paisagens em termos da visão de mundo e das atividades desenvolvidas por determinada sociedade. Nesse viés, paisagem foi sendo compreendida como o espaço habitado e arena para rituais, cerimônias, forças sociais, político-econômicas e ideológicas que projetam diferentes configurações sobre ela (ASHMORE; KNAPP, 1999). Atentaremos neste subitem às questões elevadas por esta arqueologia social em relação à cultura material, ao registro e à paisagem arqueológica.

Arqueólogos pós-processualistas preocupam-se menos com a funcionalidade da cultura material e mais com as relações sociais que elas podem informar dentro e entre suas comunidades. Nesta perspectiva, os estudos dos "estilos" de uma cultura material se tornaram populares e discorreram sobre a "maneira de se fazer" algo, incluindo as atividades de pensar, sentir e ser, como pondera Hodder (1990). O estilo está fortemente imbricado no contexto social de cada evento histórico. Mas, no entanto, esta característica não exclui o caráter relacional com outros eventos que recordam e recriam similaridade e/ou diferença na sua forma de se fazer.

Para Wiessner (1990), o estilo não se desvincula da função e tecnologia de um objeto, ao contrário, estas categorias estão relacionadas e contidas em todo o comportamento humano. Torna-se uma particularidade da cultura material que transmite informação sobre identidade pessoal e social, atuando tanto no fortalecimento desta identidade, quanto nos processos de intercâmbio de conhecimentos.

A cultura material nesta perspectiva estabelece-se sobre a identidade social de um grupo de indivíduos que fazem suas escolhas de maneira consciente e/ou inconsciente. A nosso ver, mais amplo que o próprio conceito de "estilo" é o conceito de habitus, que em sua própria construção teórica envolve temas como cultura, tarefa e hábito. Sendo globalizante, habitus integra experiências passadas, funcionando como matriz de 
percepções, apreciações e ações, tornando possível a realização de diferentes tarefas, por meio de esquemas prévios e correções incessantes dos resultados obtidos (BOURDIEU, 1983).

Considerando que a cultura material é mais social e relacional do que funcional, existe o interesse em decodificar o depósito cultural e seu simbolismo espacial. Esses significados geralmente estão entrelaçados nas formas e padrões preservados no registro arqueológico. Suas correlações com trabalhos etnográficos e etnoarqueológicos podem auxiliar na reconstrução destas relações contextuais (WHITELAW, 2004).

Estes estudos podem dirigir sua abordagem para a diferenciação dos refugos e sua configuração dentro do espaço habitado. Indo além das designações de refugo de fato, primário, secundário e de trânsito, todas orientadas por requisitos funcionais, Lane (2006) avalia que estas práticas de deposição também podem estar associadas a uma ordem social mais ampla. Assim, diferentes categorias de refugo carregam um número de associações simbólicas que relatam, em particular, os valores associados aos papéis dos homens e das mulheres dentro de determinada sociedade. A carga simbólica de cada categoria de refugo, os locais onde se acumularam e a divisão de gênero com o qual estes locais foram associados atuaram como auxiliares de organização e memória para a ordem cultural mais ampla.

Como nos atentam Pearson e Richards (2005), o depósito arqueológico nada mais é do que reminiscência de antigos espaços habitados. Estes espaços, como nos mostram inúmeras pesquisas etnográficas, possivelmente foram transformados na imagem do mundo, por meio de projeções e rituais baseados em ações paradigmáticas dos mitos.

Estudos etnográficos e etno-históricos, desde que contextualizados na área de pesquisa, oferecem um corpus bibliográfico de interesse para a interpretação do registro arqueológico. Desta forma, refugos e depósitos culturais estão amplamente associados às práticas de vida e interação social que estruturam e são estruturadas pela paisagem. Nesta perspectiva, conceitos amplos como "lugar" e "paisagem" possuem significados únicos e contextuais e estão imbuídos de história humana, construções e identidades sociais (ZENEEDO, HOLLENBACK, GRINNELL, 2009).

Talvez o grande avanço da arqueologia social foi o esforço em compreender as complexas camadas de significados que abordam processos sociais e cognitivos da paisagem, apontando realidades passadas híbridas constituídas por redes históricas de representações e práticas entre pessoas e materialidade (WHITRIDGE, 2004). 
Este, então, é o cerne da arqueologia da paisagem: trata-se não só do ambiente físico, mas também do significado locacional em que as comunidades viveram. Isto inclui não apenas a paisagem construída, mas também elementos como as rochas, as jazidas de argila, as correntes de água, as corredeiras, as florestas, as estrelas, não somente como objetos abstratos, mas como coisas significativas e experimentadas pelas pessoas e suas práticas sociais.

Adequando a dimensão social à dimensão geoambiental, a paisagem arqueológica pode expressar mais do que preocupações econômicas, funcionais e ambientais gerais; ela pode nos dizer algo sobre a singularidade dos lugares habitados, uma preocupação centrada na prática humana em todas as suas dimensões.

\subsection{Arqueologia da Paisagem: escalas de trabalho}

Procurou-se nos subitens anteriores discorrer sobre as linhas de pesquisa que abrangem a arqueologia da paisagem. Para tanto, no objetivo de analisar nossa área de pesquisa, não bastam apenas os pressupostos teóricos, os modelos e os conceitos delineados pelas linhas de pesquisa da arqueologia da paisagem. É necessário que haja instrumentos adequados para organizar as informações, inclusive quando estas abrangem diferentes esferas de análise. Nesse intuito, apresentaremos as escalas de trabalho que norteiam nossa pesquisa e possibilitam, hora, focar em determinados aspectos, hora, confrontá-los de forma adequada.

O estudo da paisagem arqueológica aborda o tema de sua "história de vida" (HEILEN, 2005), englobando o contexto sistêmico, arqueológico, ambiental e social, bem como os processos de formação/transformação de seus registros. Essas abordagens são fundamentadas por escalas de análises denominadas "espacial", "temporal" e "comportamental", que contribuem para a construção de cenários históricos (BERTRAND; BERTRAND, 2007; HOLLENBACK, 2010).

\subsubsection{Escala espacial}

Na escala espacial podemos manejar duas variáveis extremas, sendo elas a extensa e a reduzida. Na escala espacial extensa, considera-se o tamanho absoluto da área onde estão inseridos os registros arqueológicos/históricos que estamos pesquisando. $\mathrm{Na}$ escala espacial reduzida, considera-se o tamanho absoluto da menor unidade espacial. Esse tipo 
de análise oferece uma maneira simples de quantificar as escalas como uma medida combinada de textura (menor unidade espacial de análise) e extensão (paisagem que reúne essas texturas) (HEILEN, 2005).

Entre as escalas espaciais, extensa e reduzida, ocorrem múltiplos níveis de articulação entre elas. A articulação das escalas espaciais pode abarcar o nível individual, o nível doméstico/áreas de atividades, o nível da comunidade, o nível do entorno natural etc., onde se pode aplicar um mecanismo de zoom, realizando o cruzamento desses dados por meio de um olhar transversal sobre todos esses níveis (CRIADO BOADO, 1999; HEILEN, 2005; HOLLENBACK, 2010).

Dentro da perspectiva de escalas espaciais, podemos iniciar com a descrição do zoom extenso, informando sobre as características gerais da área de estudo ${ }^{7}$, cartografando as características geoambientais de interesse ao assentamento/atividade humana e, em uma segunda etapa, associando os sítios arqueológicos entre si nesta área. Espera-se, como resultado, a definição dos padrões de distribuição dos vestígios arqueológicos sobre a paisagem (ARAÚJO, 2001; CRIADO BOADO; 1999; MORAIS, 1999).

O zoom intermediário definiria marcadores locacionais que indiquem lugares onde interações e atividades pretéritas ocorreram (HOLLENBACK, 2010). A atenção especial está na articulação interna do espaço de um sítio arqueológico com sua paisagem de entorno. Associar o sítio arqueológico a sua matriz sedimentar, definir compartimentos topomorfológicos e mapear geoindicadores ${ }^{8}$ locais (MORAIS, 1999; 2006) são elementos de análise que podem resultar em uma aproximação das estratégias de construção e manutenção de uma paisagem cultural.

Em termos de elementos geoambientais na escala do sítio arqueológico e entorno, o zoom intermediário atua como um mecanismo de articulação entre as informações geomorfológicas e os insumos biológicos que propiciam definir um quadro de variabilidade paisagística para a ocupação humana pretérita (BUTZER, 2006).

A matriz topográfica tem uma estrutura e uma dinâmica traduzidas nos detalhes dos tipos de solos, distribuição da biota, possibilitando a confecção de um primeiro

\footnotetext{
${ }^{7}$ Atenta-se para esse nível de análise a descrição dos agentes físicos e biológicos, como o clima, geologia, geomorfologia, pedologia, vegetação e fauna e para o agente antrópico, como a sociedade e sua ocupação topográfica (SCHIFFER, et. al. 2010).

8 São os elementos do meio físico-biótico dotados de alguma expressão locacional para os sistemas regionais de povoamento, indicando locais de assentamentos antigos (MORAIS, 2006).
} 
quadro ambiental local. A análise pode ser conduzida no âmbito das microformas da paisagem, na escala do metro quadrado, como a forma de um fundo de vale, característica de uma vertente, cabeceiras de nascentes etc. A observação e a descrição desses atributos ambientais servem como referência para abordagem arqueológica, pois indicam a potencialidade da área para a captação de recursos alimentares e de matéria-prima indispensáveis ao estabelecimento humano pretérito (BUTZER, 2006; MORAIS, 1999; KASHIMOTO, 1997).

Em termos dos processos regidos pelos agentes físicos, biológicos e antrópicos, a unidade de análise elegida para essa escala é a vertente. Como unidade de análise, a vertente possibilita o entendimento espaço-temporal dos mecanismos morfodinâmicos atuais e passados. Dentre os processos atuantes em superfície e subsuperfície da vertente, destacam-se os efeitos denudacionais ${ }^{9}$, movimentação de massa, água de escoamento, apropriação e transformação do relevo pelo homem, o que resulta na formação e redistribuição dos vestígios culturais e nos processos pós-deposicionais do registro arqueológico (CASSETI, 1991; MORAIS, 2006; RUBIN; CARBONERA, 2011).

O zoom reduzido é a menor unidade espacial de análise (HOLLENBACK, 2010). Geralmente, em pesquisas arqueológicas realizadas nas terras baixas sul-americanas, o foco está sobre os objetos manufaturados, como o material lítico e cerâmico. Acrescentase a essa análise, a disposição dos objetos manufaturados e sua articulação com o sítio arqueológico (GALLAY, 1986). Em termos de recuperação e interpretação dos objetos manufaturados inseridos no sítio arqueológico, prospecções e escavações arqueológicas podem propiciar a visão contextual do sítio e de suas estruturas, possibilitando análises acuradas das relações intrassítio (MORAIS, 1999).

Os níveis de articulação espacial intrassítio devem obedecer a um minucioso registro dos objetos plotados em mapas de distribuição. A partir da geração desse mapa, complementado dos registros de campo, pode-se fazer correlações desses objetos com possíveis estruturas ${ }^{10}$ (ARAÚJO, 2001).

Em termos de elementos ambientais locais associados aos conjuntos e áreas de deposição arqueológica, o zoom reduzido ou microescala atua como a menor unidade geográfica de análise discernível no terreno, envolvendo particularidades que apenas esse nível de análise pode captar (BERTRAND; BERTRAND, 2007; CARR, 1984).

\footnotetext{
${ }^{9}$ Em termos gerais, denudação é o desbastamento das diversas rochas da superfície do globo, pelo efeito conjugado dos diferentes agentes erosivos (GUERRA, 1993).

${ }^{10}$ A exemplo, estruturas de lascamento, estruturas funerárias, estruturas de combustão etc.
} 
Envolve particularidades ambientais em questão de micro feições geomorfológicas, pedológicas, hidrográficas, climáticas e ecológicas. Esses elementos ambientais locais influenciam na seleção inicial dos sítios, nas atividades ali ocorridas e nos processos de formação (BERTRAND; BERTRAND, 2007, BUTZER, 2006).

Atentamos que registro arqueológico ou o arranjo dos objetos não refletem inteiramente os processos comportamentais pretéritos, mas sim, processos pósdeposicionais de origem ambiental e/ou humana. Transporte e erosão fluvial e pluvial ${ }^{11}$, atividade de roedores e agricultura contemporânea são exemplos de tais processos (CARR, 1984).

Em última instância, descrever os efeitos dos processos pós-deposicionais nos vestígios arqueológicos, como mudanças físicas e químicas em suas propriedades: cor, textura, composição, dureza, fragmentação etc. (SCHIFFER, et. al. 2010) consiste em análise apropriada em termos de microescala e processos de formação.

\subsubsection{Escala temporal e cenários de paisagem}

A análise da escala temporal precisa ser complementar à análise da escala espacial. Deve-se compreender, no âmbito da escala temporal, a extensão do tempo absoluto (HEILEN, 2005; HOLLENBACK, 2010) no qual eventos culturais e naturais ${ }^{12}$ relevantes vêm configurando e reconfigurando a paisagem em análise. Essa perspectiva temporal analisa a paisagem arqueológica como palimpsesto, ou seja, verifica no cenário atual uma grande quantidade de mudanças em diversas escalas na configuração da paisagem histórica (ANSCHUETZ et. Al. 2001; HOLLENBACK, 2010).

A confecção de cenários visa materializar de forma esquemática os ritmos de paisagem. Esses ritmos implicam em movimentos sociais sobre o meio, ocasionando a

\footnotetext{
${ }^{11}$ Esse processo ocorre com maior frequência na fase de resistasia de uma vertente, o que determina a turbidez das águas superficiais, particularizada pelo desaparecimento da cobertura vegetal. Nessa etapa, a morfogênese domina a dinâmica da paisagem, resultando na retirada do material intemperizado, reduzindo paulatinamente a camada de solo e, consequentemente, assoreando os vales (CASSETI, 2006).

${ }^{12}$ Estes eventos e transformações foram sistematizados por Schiffer como $c$-transforms ou transformações culturais, descrevendo os processos de formação cultural do registro arqueológico. Estes processos relacionam variáveis pertencentes às propriedades socioculturais e organizacionais de um sistema sociocultural com variáveis descrevendo aspectos da produção arqueológica nesse sistema. Os processos de formação não cultural são chamadas de $n$-transforms ou transformações naturais. $N$-transforms especificam a interação entre materiais culturalmente depositados e variáveis ambientais nas quais tais materiais foram depositados. Juntas, $n$-transforms e $c$-transforms, providenciam maneiras de modelar os processos por meio dos quais o sítio arqueológico adquiriu específicos atributos formais, quantitativos, relativos e espaciais (SCHIFFER, 1975).
} 
transformação das paisagens em eixos transversais. Seguindo esses eixos diacrônicos podemos percorrer a história de vida de uma paisagem, descrevendo seus diversos estados sincrônicos que já se estabeleceram (BERTRAND; BERTRAND, 2007; HOLLENBACK, 2010).

Esses cenários são articulados por unidades de ação, tempo e lugar. Em unidade de ação situa-se o funcionamento do sistema de produção material e cultural. Em unidade de tempo, estabelece-se o período estável do sistema de produção vigente e na unidade de lugar, delimita-se o espaço material onde se desenvolveu o sistema de produção (BERTRAND; BERTRAND, 2007). Nota-se que o cenário se constrói por meio de unidades que por sua vez são orientadas por escalas de análise.

$\mathrm{O}$ processo de transformação antrópico da paisagem sempre esteve ligado à organização de um determinado grupo e a uma relação de produção influenciada por uma determinada técnica. A "transformação da vertente pelo homem, que se intensifica no tempo e no espaço, não acontece simplesmente pela necessidade inata de ocupação, mas sobretudo dentro de uma lógica determinada pelas relações de produção" (CASSETI, 1991, p.86).

Dentro das relações de produção, a ação do homem (trabalho), por meio de determinados instrumentos que lhe permitem dispor de uma força (energia) sobre as diversas características do ambiente, impulsionam as transformações da paisagem e criam uma história de vida particular. A dialética entre esses três fatores internos determina o ritmo e o funcionamento do sistema de produção, que por sua vez desenha o conteúdo material e cultural de uma paisagem (LUMBRERAS, 1974).

A proposta é a confecção de cenários socioespaciais equivalentes ao número de sistemas regionais de povoamento ${ }^{13}$ identificados. O método possibilita a reconstituição contínua da paisagem por meio de combinações socioecológicas complexas. Essa reconstituição deve apresentar um sistema de cenários articulados e dependentes uns dos outros, ao mesmo tempo no espaço social e no tempo. A elaboração de cenários históricos permite analisar, por meio de suas categorias sociais e ecológicas, as formações, transformações e rupturas na paisagem (BERTRAND; BERTRAND, 2007; CASSETI, 1991).

Cientes de que o fenômeno paisagem apresenta-se em um estado de contínua transformação, que não depende somente dos agentes e processos que o provocam, mas

\footnotetext{
${ }^{13}$ Termo cunhado por José Luiz de Morais (1999-2000), que será explicado no item1.4.
} 
também de suas fases anteriores; a paisagem arqueológica, objeto de nosso estudo, desdobra-se em diversos cenários, cujos eixos históricos e espaciais formam um organograma que nos permite identificar as causas e os efeitos no contexto arqueológico analisado. No eixo histórico, partiremos do cenário pré-colonial, quando houve a ocupação e deposição arqueológica, até o cenário atual. No eixo espacial, as combinações socioespaciais permitirão avaliar ou projetar o uso do solo, a cobertura vegetal, a dinâmica da vertente, a relação de produção e outras características dentro de cada cenário progressivo (BERTRAND; BERTRAND, 2007; BUTZER, 2006; CASSETI, 1991).

Dentro da extensão absoluta de tempo e de seus cenários, existe a escala temporal do intervalo, ou o lapso de tempo que durou um fenômeno arqueológico. Os intervalos podem ser avaliados por meio das datações absolutas, que permitem inserir os sítios arqueológicos em faixa (s) cronológica (s) especifica (s) e também pelo detalhamento de informações históricas que narram os eventos ocorridos em determinada região (HEILEN, 2005; HOLLENBACK, 2010).

\subsubsection{Escala comportamental}

A última escala de análise é a comportamental, sendo composta por três níveis: 1nível de interação, 2- nível de atividade e 3- sistema comportamental (HOLLENBACK, 2010).

O nível de interação é a menor escala comportamental e refere-se a como as relações mecânicas, químicas, termais, acústicas ou visuais interagem entre pessoas, artefatos e ambiente (HOLLENBACK, 2010; SCHIFFER, 2010).

O nível de atividade implica nas interações de atividades exercidas pelo indivíduo, pela família ou pelo grupo. Cada atividade exercida é composta de interações ou conjunto de interações relacionadas, ocorrendo em um lugar particular. Para a atividade acontecer, ela deve proceder de um nível de interação para outro, incluindo fonte de energia, como pessoas, animais, fogo, corrente de água, luz solar, entre outros (SCHIFFER, 2010).

Schiffer (2010) afirma que toda atividade envolve a relação de humanos com artefatos em determinado lugar. Assim, podemos associar o nível de atividade com a organização dos artefatos numa perspectiva de sistema de assentamentos, estudando cada sítio por meio de seu desempenho de interações e atividades. Estratégias de aquisição de matéria-prima, confecção, organização, uso e reuso dos artefatos (BINFORD, 1979) são unidades de análise do nível de atividade. 
O sistema comportamental é um conjunto de padrões que articulam os grupos humanos com seu ambiente de entorno e com outros sistemas comportamentais independentes. O sistema comportamental inclui pessoas e elementos do mundo material, no qual ocorrem interações e atividades. Essas redes de atividades ocorrem e modificam a paisagem e são compostas por um ou mais sistemas comportamentais interligados. Essa definição não se relaciona com o território de um grupo particular, ou uma área cultural construída em larga escala. A paisagem formada por sistemas comportamentais são redes de relações, padrões e atividades humanas (HEILEN, 2005).

Um ponto importante a ser considerado é que a paisagem arqueológica não pode ser tomada por paisagem sistêmica. "Objetivamente, sítios não são ipso facto lugares ou rotas" (HEILEN, 2005, p. 22). Em nível básico, os sítios são concentrações de materiais arqueológicos definidos por meio de um esquema metodológico. Em termos de sistema comportamental, sítios arqueológicos são incorporados a lugares de atividades que podem ser interligados em uma ou mais redes de paisagens. Paisagens sistêmicas colocam maior foco em artefatos e suas associações, que permitem inferir relações funcionais e padrões de atividades (Ibidem, 2005).

\subsection{Cartografia da paisagem arqueológica}

O presente capítulo de tese tem por objetivo confeccionar um corpus teóricometodológico adequado para a análise dos sítios arqueológicos resgatados nesta pesquisa em relação a seu contexto arqueológico regional.

Nesta perspectiva, nortearam nossa pesquisa questões como os grupos humanos pretéritos se relacionavam com a paisagem em termos de organização e uso dos recursos naturais, de organização socioespacial e cognitiva e com outros grupos filiados a distintos sistemas regionais de povoamento.

Nossa estratégia para responder estas questões e avançar nos estudos de arqueologia da paisagem foi o de explorar os conceitos delineados pelas linhas de pesquisa descritas acima, vinculando-os a uma rede integrada de análise cartográfica da paisagem.

Iniciamos o debate delimitando uma área de atuação, focando no que está dentro dessa fronteira arbitrária. Isso não exclui relacionar os dados aqui descritos e analisados com os dados de outras regiões. Nossa proposta é debater amplamente nossos dados 
regionais com outras áreas de estudos, tanto no âmbito arqueológico quanto no de história de ocupação regional.

Nossa área de atuação engloba quatro bacias hidrográficas contíguas: São José dos Dourados, Turvo-Grande, Baixo Pardo-Grande e Sapucaí-Grande, todas localizadas na região norte do estado de São Paulo. Delimitadas as quatro bacias, elas serviram de base para o primeiro nível de informação cartográfica, especificado por suas características geoambientais, como: topografia, hidrografia e geomorfologia, almejando integrar estes aspectos básicos.

Em um segundo nível de informação cartográfica, foram demarcados os sítios arqueológicos que dão textura à paisagem regional. O objetivo é iniciar a descrição das relações entre estes sítios na escala de tempo e espaço.

Em um terceiro nível de informação cartográfica, procurou-se aliar informações arqueológicas e históricas para delimitar sistemas de povoamento pré-colonial e aqueles observados já em fase de desmembramento durante os séculos de colonização. Neste nível é que se fez uma relação mais profunda entre escala espacial e escala temporal, adicionando informações cronológicas, por meio de datações absolutas, quando se tratou de sítios arqueológicos; ou relativas, quando se referiu às informações históricas primárias e secundárias.

Destacamos que os três níveis de informação cartográfica nos possibilitaram identificar parte da dimensão relacional e histórica da área em estudo, com contribuição dos estudos de arqueologia da paisagem para o norte de São Paulo.

\subsection{Processos deposicionais e pós-deposicionais}

O processo de formação do registro arqueológico engloba diversos fatores que podem nos ajudar a entender o comportamento humano passado (HEILEN, 2005; HOLLENBACK, 2010). O registro arqueológico não é formado por um único processo de uso e ocupação, e sim na constante reutilização e reocupação de seus objetos e de seu espaço (ZEDEÑO, 1997).

A reutilização dos objetos arqueológicos remanescentes ocorre por uma mudança em seu uso, no usuário, ou em sua forma, depois de ter servido a uma função específica em uma determinada atividade (SCHIFFER et. al., 2010). Para fins 
arqueológicos, Schiffer et. al. (2010) definiu quatro tipos de processos de reutilização: ciclismo lateral, reciclagem, uso secundário e processos de conservação ${ }^{14}$.

Essa gama de objetos reutilizados junto a outras transformações de artefatos do contexto sistêmico para o contexto arqueológico é chamada de deposição cultural. Esse conjunto de processos diretamente responsáveis pelo depósito de materiais no ambiente é capaz de fornecer informações sobre o comportamento humano passado (Ibidem, 2010).

Cabe salientar também que os processos envolvidos na formação do contexto arqueológico não assumem uma dinâmica linear, mas cíclica, em que os processos de ocupação e reocupação da paisagem estão interligados. A fissão de um assentamento, por exemplo, pode gerar a exploração de novos territórios, que por sua vez iniciará um novo processo de colonização, assentamento, expansão, consolidação e fissão. Esse processo pode ocorrer em áreas novas, nunca antes exploradas, colonizadas ou assentadas, ou pode ocorrer em áreas que nunca foram totalmente abandonadas, como terras ancestrais, aldeias e locais rituais. Essas terras podem ser reocupadas e/ou ressignificadas e são consideradas como lugares persistentes dentro de um território amplo. Antigas aldeias são reocupadas, locais ancestrais são visitados, ocupados temporariamente, santuários são mantidos limpos e cuidados etc. (ZEDEÑO, 1997).

O processo cíclico de reocupação traz fortes implicações na configuração dos assentamentos e habitações. Traduzido muitas vezes na expansão e contração das aldeias indígenas, esse processo demonstra que a disposição das habitações está, em alguns casos, em lenta e contínua movimentação, gerando mudanças consideráveis no registro arqueológico, que incorpora esses movimentos, misturando-se evidências materiais de tempos diferenciados (MOI, 2007; MORALES, 2007; SCHIFFER et. al., 2010). O resultado desse processo sistêmico é o "superdimensionamento de área e população de um sítio, mascarando os padrões de organização espacial e de utilização interna dos assentamentos” (MORALES, 2007, p. 85).

\footnotetext{
${ }^{14}$ Ciclismo lateral envolve a mudança somente no usuário do artefato ou no uso da unidade social. A transferência do uso do artefato de indivíduo para indivíduo e de grupo social para grupo social constitui ciclismo lateral contanto que a forma do artefato e o uso não sejam alterados. Constitui-se em um processo de muita dificuldade para a inferência arqueológica, pois, em si, não há mudança em sua propriedade formal. Reciclagem é o processo pelo qual o artefato, depois de um período de uso, é submetido a um novo processo de manufaturamento, resultando em uma mudança na forma do artefato e possivelmente em seu uso. O uso secundário é uma alteração no uso do objeto, mas não em sua forma. Bens de sepultamento são importantes exemplos arqueológicos de uso secundário. Artefatos empregados em atividades do cotidiano são muitas vezes secundariamente usados em rituais mortuários e depositados com o falecido. Finalmente, processo de conservação é um conjunto de grande variedade de usos secundários, que pode resultar na preservação em longo prazo (SCHIFFER et. al., 2010).
} 
Assim, em certas circunstâncias, pode ocorrer um adensamento de vestígios arqueológicos uniforme, em alguns locais, ou aleatório, em outros, refletindo em dois conjuntos de processos de formação distintos, em relação ao tempo e ao processo de expansão ou contração da aldeia (CARR, 1984).

No entanto, outro processo pode entrar em voga na transformação de um assentamento, ou em outra escala, de um território. É o que Zedeño (1997) denominou recuperação. O processo refere-se à reciclagem, aquisição, ou mesmo usurpação de um território anteriormente ocupado por outro grupo. Ocorre, assim, a posterior reutilização das modificações da paisagem deixadas por antigos ocupantes, ou seja, o processo de recuperação envolve o início da formação do território de uma sociedade onde outra relacionada residia.

A teoria pós-deposicional de Clarke (1973) demonstra que as transformações ocasionadas no registro arqueológico ocorrem de duas formas complementares ${ }^{15}$. As transformações culturais que se relacionam com as variáveis pertencentes às propriedades socioculturais e as transformações naturais que especificam as interações entre materiais culturalmente depositados junto às variáveis ambientais que interferem nesse processo. Articuladas, essas transformações modelam os processos que o sítio arqueológico adquiriu no momento de sua observação e intervenção (SCHIFFER, 1975).

A análise aplicada aos processos de formação de sítios arqueológicos e paisagem respalda-se nos processos ocorridos na história de vida de uma vertente, ocasionando deslocamento, movimentação, enterramento, que reorganizam espacialmente os artefatos inseridos em um depósito arqueológico (RUBIN; SILVA, 2004).

Em sentido amplo, a vertente constitui elemento dominante de uma paisagem, pois é a síntese da dialética entre forças endógenas e exógenas da Terra, resultantes de processos rítmicos espaços-temporais. Em termos morfológicos, a vertente possui planos de declives variados, agrupando três tipos de formas: côncava, convexa e plana. As

\footnotetext{
15 Transformações são modeladas através do uso de dois tipos de leis arqueológicas. O primeiro, $c$ transforms ou transformação cultural, descreve os processos de formação cultural do registro arqueológico. Essas leis relacionam variáveis pertencentes às propriedades socioculturais e organizacionais de um sistema sociocultural, com variáveis descrevendo aspectos da produção arqueológica nesse sistema. As leis de formação não cultural são chamadas de $n$-transforms ou transformação natural. $N$-transforms especificam a interação entre materiais culturalmente depositados e variáveis ambientais, nas quais tais materiais foram depositados. Juntas, $n$-transforms e $c$-transforms providenciam maneiras de modelar os processos por meio dos quais o sítio arqueológico adquiriu específicos atributos formais, quantitativos, relativos e espaciais (SCHIFFER, 1975).
} 
formas das vertentes são modeladas por processos de denudação ${ }^{16}$ e representam a conexão dinâmica entre o interflúvio e o fundo de vale (CASSETI, 1992; CHRISTOFOLETTI, 1980; GUERRA, 1993).

Assim como a vertente está sujeita aos processos morfológicos, sítios arqueológicos inseridos em determinados pacotes sedimentares sofrem esses efeitos denudacionais. Pensando de forma conjunta, o depósito arqueológico não deixa de ser um elemento agregado aos processos de formação da vertente e sobre ele resultam historicamente duas forças componenciais: (1) o componente perpendicular, caracterizado pela infiltração da água no solo, responsável pela intemperização das rochas, que possibilita a formação do solo e de material para eventual transporte, e o componente paralelo, responsável pelo processo denudacional (morfogênese), ou seja, pelo transporte do material coluvial ${ }^{17}$ (CASSETI, 1992).

Em regiões intertropicais a chuva caracteriza-se como processo de maior importância denudacional, implicando fluxo por terra (escoamento), que responde pela redução do material coluvial. Ainda como exemplo de componente paralelo, incluem-se os fenômenos de solifluxão (movimento de massa da ordem de alguns decímetros/mês ou ano, evidenciado, sobretudo, nas regiões periglaciais); rastejamento ou creeping (movimento de massa da ordem de centímetros/ano, constatado nas regiões tropicais); e deslizamento de massa ou escorregamentos (movimentos rápidos), constatados com frequência nos períodos de grandes intensidades pluviométricas (CASSETTI, 1992; CHRISTOFOLETTI, 1980).

O processo pluvial é procedido pela erosão, que tem por função desagregar e remover partículas de solos ou fragmentos de rochas. Esse processo de transporte é entendido como escoamento pluvial e aparece em maior quantidade, quando a água precipitada é maior que a velocidade de infiltração ${ }^{18}$. De grande importância aos processos pós-deposicionais arqueológicos, o escoamento pluvial pode se dar de forma difusa e de forma concentrada, causando o transporte de sedimentos, rochas e materiais

\footnotetext{
${ }^{16}$ Em termos gerais, denudação é o desbastamento das diversas rochas da superfície do globo, pelo efeito conjugado dos diferentes agentes erosivos (GUERRA, 1993).

17 O colúvio constitui-se de material transportado de um local para outro, principalmente por efeito da gravidade. O material coluvial só aparece no sopé de vertentes ou em lugares pouco afastados de declives que lhe estão acima (GUERRA, 1993).

${ }^{18}$ Esse processo ocorre com maior frequência na fase de resistasia de uma vertente, o que determina a turbidez das águas superficiais, particularizada pelo desaparecimento da cobertura vegetal. Nessa etapa, a morfogênese domina a dinâmica da paisagem, resultando na retirada do material intemperizado, reduzindo paulatinamente a camada de solo e, consequentemente, assoreando os vales (CASSETI, 2006).
} 
arqueológicos para a jusante, em direção aos fundos de vales (CHRISTOFOLETTI, 1980; RUBIN; SILVA, 2004).

A natureza do transporte pluvial se dá pela equação velocidade das águas rugosidade da superfície. A erosão laminar ocasiona a suspensão e transporte de partículas e sedimentos finos, expondo as partículas mais grosseiras. A formação de uma superfície irregular propicia à formação de fluxo concentrado, cujas correntes ascensionais deslocam os grãos maiores por saltação, sempre carreados em direção à jusante. Sítios arqueológicos inseridos em locais inclinados da vertente tendem a sofrer processos erosivos que deslocam camadas sedimentares de sua matriz, em um primeiro momento, e posteriormente, por meio de sulcos, calhas e ravinas $^{19}$, formadas pelo escoamento pluvial, transportam seus vestígios arqueológicos em direção à jusante (CHRISTOFOLETTI, 1980; RUBIN; SILVA, 2004).

Assim, é importante verificar a rede de feições erosivas de pequeno e médio porte que ocorrem na área de um sítio arqueológico e seu entorno, com o propósito de detectar a retirada e o direcionamento do deslocamento dos vestígios de seu local de origem ao seu depósito em outros contextos (RUBIN; SILVA, 2004).

Vale salientar que a erosão e a deposição são processos conjuntos e interdependentes, mas que não acontecem necessariamente no mesmo local. Erosão é predominante em algumas áreas e, como mencionado, compõe arranjos de formas específicas e generalizadas na superfície da vertente. Deposição, por outro lado, forma um registro sedimentar que pode se acumular em pontos à jusante, como as nascentes, áreas com rupturas de declives, fundos de vale e corpos de água de várias ordens. Em geral, a análise dos sistemas erosivos e deposicionais, relevantes ao sítio arqueológico, deve ser feita nas diferentes unidades da vertente (BUTZER, 2006).

Genericamente, a vertente possui unidades definidas em função da forma e dos processos morfogenéticos dominantes e normalmente atuantes sobre ela. Para este trabalho, foram adotadas três unidades hipotéticas que apresentam o modelo de Dalrymple, Blong e Conacher (1968 apud CHRISTOFOLETTI, 1980, p. 41) de forma resumida.

\footnotetext{
${ }^{19}$ Feições erosivas de pequeno porte como sulcos (largura de $10-30 \mathrm{~cm}$ e profundidade de $5-15 \mathrm{~cm}$ ) e calhas (largura de 1-10 m e profundidade de $5-30 \mathrm{~cm}$ ) provocam o desprendimento e o transporte de partículas na superfície do solo, podendo ser carreados os materiais arqueológicos de menor massa. Feições erosivas de médio e grande porte como as ravinas (largura superior a $1 \mathrm{~m}$ e profundidade superior a $0,5 \mathrm{~m}$ ) podem desprender, transportar e movimentar grandes quantidades de colúvio e, consequentemente, vestígios materiais contidos em pacotes sedimentares (RUBIN; SILVA, 2004).
} 
Primeiramente temos a unidade do interflúvio ou topo de morro. Essa unidade caracteriza-se por apresentar processos pedogenéticos associados ao movimento vertical da água superficial. Por estar associada à parte mais alta da vertente, essa unidade sofre transformações ocorridas pela descida de materiais do horizonte de solo superior, processo denominado "eluviação". Outros processos como deslizamentos e desmoronamentos podem ocorrer formando terracetes nessa unidade. A segunda unidade é a de declive coluvial ou alta, média e baixa vertente. Nessa unidade, ocorre o intemperismo químico, bioquímico e físico responsável pela formação de depósitos de colúvio e elúvio ${ }^{20}$. Ocorre o transporte de material pelos movimentos coletivos do solo, normalmente ocasionados pela ação da água superficial e subsuperficial. A última unidade da vertente é a do fundo de vale, que pode ser dividida em declive aluvial ${ }^{21}$, onde ocorre a deposição aluvial oriunda do movimento das águas fluviais; margem de curso de água, onde ocorrem a erosão eólica, deslizamento e desmoronamento ocasionados pelo retrabalhamento das águas fluviais; e leito do curso de água, responsável pelo transporte de material para jusante pela ação da água superficial (CHRISTOFOLETTI, 1980; GUERRA, 1993).

Conforme se considerou anteriormente, a paisagem, ou mais especificamente a vertente, resulta da ação de processos naturais e antrópicos ao longo do tempo, sendo sua aparência ou forma atual resultante de diferentes componentes que integram essas relações. Em nossa área de estudo, os agrupamentos humanos, concernentes à história do processo de apropriação e transformação da paisagem, provocaram o agravamento de fatores processuais e que intensificaram os processos exógenos. Como resultante das transformações antrópicas, ocorreram e ainda ocorrem alterações no processo erosivo, que resultam numa ação mais agressiva dos processos morfogenéticos, com consequente degradação ambiental (CASSETI, 1992).

A degradação ambiental das vertentes provoca uma variabilidade de distúrbios nos sítios arqueológicos. Como resultado, ocorrem mudanças na inclinação, orientação e posição vertical e horizontal, que distorcem ou eliminam as relações tridimensionais desses sítios. Movimentação vertical pode expor os materiais arqueológicos aos diversos processos exógenos, como intemperismo físico, químico e bioquímico, erosão em

\footnotetext{
${ }^{20}$ Depósito detrítico ou simples capa de detritos resultantes da desintegração da rocha matriz permanecendo in situ. O termo elúvio é o oposto do material transportado pelas águas dos rios, isto é, alúvio (GUERRA, 1993).

${ }^{21}$ Depósito fluvial detrítico de idade bem recente (Quaternário), que pode ser litificado com o tempo, transformando-se em rocha aluvial (SUGUIO, 1998).
} 
diversos níveis, exposição ao sol, além das ações antrópicas de grande impacto. Movimentação horizontal pode gerar dispersão parcial e carreamento dos vestígios para as redes erosivas ou fundos de vales e corpos de água (BUTZER, 2006).

Cabe salientar que degradações ambientais provocadas por processos antrópicos são interdependentes dos processos naturais, que em conjunto impactam de forma intensiva a dinâmica da vertente.

\subsection{Cultura material na perspectiva de habitação}

Em arqueologia, o conceito de "cultura material" é comumente utilizado como fonte ou documento através dos quais se abordam as sociedades do passado (PESEZ, 1998). Para Shanks e Tilley (1992), cultura material expressa a "objetificação do ser social", onde matéria bruta é transformada pelas práticas sociais e trabalho produtivo em um objeto cultural, seja ele um produto para consumo imediato, uma ferramenta ou um trabalho de arte. O importante a reter nessa consideração é a consequência inevitável da transformação da matéria bruta num objeto cultural, por meio do trabalho que se realiza dentro de um campo social simbolicamente construído.

Julian Thomaz (2007) faz a ressalva de que o conceito de cultura material traz em si a dicotomia inerente entre aquilo que é mental e aquilo que é material ${ }^{22}$. Explica o autor que o conceito é limitado, uma vez que não há formas de cultura que não possuam uma materialidade: linguagem, relações de parentesco, sistemas jurídicos, crenças religiosas etc, são incorporados em instituições, situações sociais concretas, ou seja, elas não flutuam num éter puro.

Essa dicotomia, inerente ao conceito apresentado, leva-nos, por um lado, a ver cultura material repousando sobre a distinção entre um mundo interior e outro exterior, na qual as ideias são emitidas para fora da mente e, posteriormente, dão forma à matéria bruta e, por outro, e nesse mesmo processo, a matéria bruta formada deixa a esfera da natureza e entra na esfera de cultura (THOMAZ, 2007).

Bezerra de Meneses (2000) alerta-nos sobre a inconveniência de acentuar a polaridade entre aquilo que é material e aquilo que é imaterial. Pondera que o material

\footnotetext{
${ }^{22}$ Em um ensaio sobre Cultura Material e História Cultural, Dolores Newton (1986, p.15) citando Bohannan (1973, p.364) sublinha "a cultura material como único fenômeno cultural codificado duas vezes: uma vez na mente do artesão e a outra na forma física do objeto. Essa dupla codificação permite comparar os três fenômenos culturais, ou seja, o artefato, bem como seus aspectos cognitivos e comportamentais".
} 
tem sua dimensão imaterial de significado e valor, enquanto que o imaterial tem sua dimensão material que lhe permite realizar-se. E complementa: "as diferenças não são ontológicas, de natureza, mas basicamente operacionais" (BEZERRA DE MENESES, 2000, p.31).

Se "imaterialidade só pode se expressar por intermédio da materialidade" (Ibidem, 2010, p.31), Bezerra de Meneses adverte que, a exemplo, o "saber-fazer" como conhecimento abstrato, conceitual, imaterial é também um conhecimento corporificado, uma memória-hábito ou memória corporificada.

É importante sublinhar e apreender a consideração levantada por Bezerra de Meneses (2010), sobre o risco de cairmos no erro de considerarmos a cultura material como objeto ou conjunto de objetos consumados, oferecendo a nós apenas suas superfícies externas, fixas e imutáveis. A imaterialidade expressa pela materialidade por sua vez não é algo estável, mas sim, um conjunto de relações, de acontecimentos entrelaçados, ou seja, sua imaterialidade transborda de sua materialidade permitindo-nos seguir os seus fluxos vitais (INGOLD, 2012).

Uma mudança de paradigma básica que temos que nos esforçar a fazer é entender cultura material, não como captura e contenção de significados, mas como escoamento e fluxo de significados. É necessário compreender que a matéria está em constante movimento e variação, onde suas superfícies externas não encapsulam, mas relacionamse e trocam continuamente materiais e energia (INGOLD, 2012). Se, por um lado, o saber fazer é memória-hábito corporificada no material, por outro, o material está em constante relação com os indivíduos, suas práticas sociais e a paisagem, cambiando fluxos relacionais.

Nesse ponto da explanação é apropriado invocar o conceito original de cultura para enfatizar o que estamos expondo. Alfredo Bosi (1993) recupera a etimologia das palavras "cultura", "culto" e "colonização" e nos oferece um importante caminho. Ambas as palavras originam-se do verbo latino colo que significa "eu moro, eu ocupo a terra e, por extensão, eu trabalho e cultivo o campo".

Semelhantemente a Bosi (1993), Bezerra de Meneses (2010) atenta-se no significado das palavras como um importante campo de entendimento. Assim, o verbo latino colo pode ser complementado pelo verbo latino habeo, que significa possuir, manter relações com alguma coisa, apropriar-se dela e, adicionado a partícula $i t$, que indica reforço, o verbo hábito expressa a noção de constância e continuidade, pertencimento e identidade que nos situa no espaço. "Essa relação entre alguém e a coisa 
é existencial, pressupondo tempos dilatados ("morar", "moradia" são palavras que também explicitam esse conteúdo de extensão temporal do habitar)" (BEZERRA DE MENESES, 2010, p. 27).

O morar, ocupar, pertencer e continuar na terra são a essência das palavras cultura e hábito. Cultura e hábito estão tanto enraizados na terra quanto na memória daqueles que habitam a terra dando um caráter cumulativo, uma densidade e vivacidade a essa terra (BOSI, 1993). Esse demorar-se é o que dá experiência do permanecer e é o traço fundamental do homem como ser indivíduo e ser social (HEIDEGGER,1995).

A cultura incorporada à terra não se refere apenas ao seu trato, mas também o culto aos mortos, culminando na relação do enterro sagrado e o amanho do solo, a terra que alimenta os vivos e abriga os mortos, gerando em ambas as esferas a memória dos antepassados (BOSI, 1993). Se pudéssemos sintetizar a riqueza da essência do conceito de cultura seria "o conjunto das práticas, das técnicas, dos símbolos e dos valores, que se devem transmitir às novas gerações, para garantir a reprodução de um estado de coexistência social (Ibidem, 1993, p.16).

Recuperamos os conceitos de cultura e hábito para enfatizar que o que chamamos de cultura material nada mais é que o processo contínuo de construção do habitar. Como disse Heidegger (1995, p.1) "parece que só é possível habitar o que se constrói. Este, o construir, tem aquele, o habitar, como meta". Mais uma vez, caímos no significado das palavras, onde a palavra construir - 'buan' - do antigo alemão, também significa habitar, permanecer e morar. Construir, nesta perspectiva, significa que o homem é à medida que habita, significando ao mesmo tempo proteger, cultivar e edificar. Construir (buan) expressa o sentido de ser e estar sobre a terra, permanece imanente a experiência cotidiana do homem, aquilo que desde sempre é, ou aquilo que é "habitual" (Ibidem, 1995).

Após esta explanação, fica difícil desassociar a obra dos homens do seu habitar. Assim, nossa perspectiva de cultura material, ou dos materiais arqueológicos, assume a perspectiva da habitação segundo a qual "a paisagem é constituída como um registro permanente de vida e obras de gerações passadas que a habitaram e deixaram algo de si mesmas" (INGOLD, 2000, p.189, tradução nossa).

O termo construir (buan) implica em prática, técnica, trabalho (cultus, habeo) que, para Ingold (2000), pode ser equivalente a "tarefa". Tarefa é definida como qualquer operação prática, realizada por um agente especializado em um ambiente, como parte de suas atividades habituais de vida. Em outras palavras, as tarefas são os atos constitutivos da habitação. "Cada tarefa toma sentido da sua posição dentro de um conjunto de tarefas, 
realizadas em série ou paralelo e, normalmente, por muitas pessoas que trabalham em conjunto" (Ibidem, 2000, p.195, tradução nossa).

Tomando ainda o pensamento de Ingold (2000) como premissa, uma das principais características das práticas técnicas humanas reside na sua inserção na corrente de sociabilidade. Trata-se de todo o conjunto de tarefas, em seu entrelaçamento mútuo, a que o autor se refere pelo conceito de taskscape. Assim, como a paisagem é uma série de recursos relacionados, por analogia, a taskscape é um conjunto de tarefas relacionadas.

Nesse ponto, existe a congruência entre o processo de habitar, construir e sociabilizar, considerando a paisagem como campo de múltiplas relações sociais. Essas relações sociais são estabelecidas por uma identidade social que predispõe cada grupo, consciente e / ou inconscientemente, a fazer suas escolhas.

A evidência das ações humanas passadas não está contida dentro da cultura material, ou dos artefatos, mas se mostra pela reunião de relações que o entendimento das palavras cultura, hábito e construir podem nos revelar dentro do processo de habitar. Assim, o limite de cultura material não é onde suas superfícies a encerram, mas onde alguma coisa dá início a sua essência, ela é a própria relação entre o lugar e o homem que nele habita e faz das "coisas ${ }^{23 ", ~ a ~ e s s e ̂ n c i a ~ d e ~ s e u s ~ l u g a r e s ~(H E I D E G G E R, ~ 1995 ; ~}$ INGOLD, 2012).

\subsubsection{As Cadeias de Atividades}

Construir algo e usá-lo, cambiá-lo, abandoná-lo, reciclá-lo ou destruí-lo consiste em habitar o mundo. Essa corrente de tarefas sociabilizadas foi de certa forma abordada pela escola francesa de arqueologia e antropologia (BALFET, 1991; DESROSIERS, 1991; LEMONNIER, 2010; LEROI-GOURHAN, 1987) e arqueologia comportamental (SCHIFFER; SKIBO, 1997; 2008; WALKER, 2010).

Por meio da sobreposição de conceitos como escolhas técnicas, cadeia operatória, cadeia comportamental e sistemas técnicos, estas duas escolas abordam

\footnotetext{
${ }^{23}$ Cultura material ou artefatos que atingem o reconhecimento desta forma são 'coisas', no sentido de reunir redes de pessoas, práticas e materiais, e eles formam pontos de entrada a partir da qual estas redes podem ser interceptadas. Podemos dizer que tal coisa se abre e revela um mundo. Mas o mundo não está contido dentro da coisa: ele faz o seu trabalho, levando-nos a um nexo relacional (THOMAZ, 2007).

O conceito de "coisa" sugere a reunião integradora. A palavra coisa deriva de sua raiz thing na língua alemã, ou o lugar onde as pessoas se reúnem para resolver suas questões. A coisa assim concebida acarretaria num parlamento de relações (HEIDEGGER, 1995).
} 
grupos sociais que, através de uma série de tarefas, fabricam, usam, trocam, descartam e reciclam materiais que os relacionam com a paisagem e com outros grupos sociais.

Primeiramente, "escolhas técnicas" compreende a interação de gestos de um artesão, relacionadas a uma cadeia de atividades que produzem um objeto (SCHIFFER; SKIBO, 1997). Sabe-se que as escolhas que indivíduos de uma determinada sociedade fazem ao adotar, rejeitar ou modificar um componente técnico nem sempre sugerem uma escolha puramente material (ou puramente técnica, utilitarista etc.). Ela pode estar relacionada a diversas esferas de representações, como religião, poder social, gênero, estética etc., que pesam fortemente sobre a maneira em que um objeto é pensado ou produzido e sobre o destino daqueles que o usam (LEMONNIER, 2010; WALKER, 2010).

Em segundo lugar, escolhas técnicas, compreendidas como gestos em ação na produção de um objeto, implicam numa sequência operacional. Essa sequência ou cadeia operatória é instituída como o processo geral que conduz um dado estado de matéria para outro estado transformado. Tomado como um recorte de uma tarefa que se interliga a outras, normalmente, não há como indicar onde uma sequência começa ou termina (LEMONNIER, 2010).

A cadeia operatória se apresenta como um encadeamento de ações, gestos e instrumentos constituintes de um processo técnico em suas grandes etapas de produção e uso. O conjunto dessas operações que um grupo social organiza e efetua, de acordo com os meios de que dispõe, resulta na satisfação de uma necessidade socialmente reconhecida (BALFET, 1991).

Atenta-se nesse processo a três detalhes importantes:

1- nem sempre a matéria a ser transformada pelas ações, gestos e instrumentos é uma matéria-prima ou bruta, assim como nem sempre a matéria transformada é um produto acabado, pronto para o consumo. Esse detalhe faz pensarmos no encadeamento das ações dentro de um grupo social e para além, na sua interação com outros grupos sociais numa rede de sociabilidade (BALFET, 1991; BOURDIEU, 1983; INGOLD, 2000);

2- o material transformado é assim realizado por meio do conhecimento técnico de um indivíduo relacionado a seu grupo social e;

3- existem sequências operatórias apreendidas ou integradas como práticas muito frequentes no grupo social, enquanto outras são raras ou excepcionais e demandam uma 
maior mobilização técnica por meio da memória - hábito e transmissão (BALFET, 1991; LEROI-GOURHAN, 1987).

Numa escala mais ampla, Lemonnier (2010) chamou de "sistema técnico" uma unidade de estudo que comporta várias cadeias operatórias articuladas, mostrando a relação das técnicas com outros fenômenos sociais.

O sistema técnico engloba três tipos de fenômenos e três tipos de níveis de interação. Os três tipos de fenômenos são: 1- do processo de confecção do objeto em curso, pelo qual ocorre a ação técnica sobre a matéria; 2- dos processos subdivididos em cadeias operatórias que reagrupam as sequências gestuais e 3- dos conhecimentos, exprimível por seus atores. Sobre os níveis de interação temos: 1- as interações entre os elementos envolvidos numa determinada tecnologia, 2- entre as várias técnicas desenvolvidas por uma dada sociedade que juntas constituem o sistema técnico real e 3entre o sistema técnico e outros componentes da organização social (Ibidem, 2010).

Assim, um sistema técnico é a combinação de vários processos, que se articulam uns aos outros, com dependências e ajustamentos recíprocos, de acordo com sua singularidade ou convergência. Este sistema prioriza a análise das relações sociais que se estabelecem no momento do controle e da utilização das forças produtivas, os efeitos diretos de certos processos técnicos sobre a organização social dos grupos que os implementam e das condições técnicas e sociais que determinam a produtividade do trabalho (Ibidem, 2010).

Rastrear sistemas técnicos no registro arqueológico não é tarefa de fácil alcance para a arqueologia. O registro arqueológico, além de colmatar diversas fases de ocupação humana, também deixa impresso na sua fisicalidade, os processos de formação que mesclam atividades antrópicas às forças naturais. Esses processos não são abordados diretamente dentro dos conceitos de cadeia operatória e sistemas técnicos, deixando para trás uma lacuna inferencial.

Nesse ponto, seria benéfico trazer à planície de discussão, o conceito de cadeia comportamental que muito tem em comum com o conceito de cadeia operatória. No entanto, cadeia comportamental, ao contrário de cadeia operatória, não se restringe aos processos de manufatura, debruçando-se também sobre as interações entre o uso, manutenção, reutilização, deposição e processos pós deposicionais (SCHIFFER; SKIBO, 2008).

Dentro do conceito de cadeia comportamental, está embutido o conceito de história de vida do artefato, que consiste em ferramenta versátil para redes de 
monitoramento de interações entre pessoas e artefatos, outras pessoas, com a paisagem, com o grupo social e entre indivíduos de grupos sociais distintos. Esse conjunto de relações, em vários níveis de escala comportamental e espacial, forma uma "cadeia" (WALKER, 2010).

Esse engajamento do conceito de cadeia comportamental, com o registro arqueológico e suas variadas escalas de análise, pode fornecer elementos complementares para uma compreensão adequada das práticas sociais pretéritas e seus campos de atuação, de desempenho, de relacionamento, sempre focando na cultura material e o que ela representa (Ibidem, 2010).

O conceito de "cadeia" para a arqueologia comportamental pode variar em número e níveis de interação entre pessoas e artefatos ao longo de sua história de vida. Ou seja, o conceito enfatiza que relações sociais existem concomitantemente com as relações materiais, sendo esses materiais carregados de significados para aqueles que o fazem, usam, trocam, reciclam etc. (SCHIFFER; SKIBO, 2008; WALKER, 2010).

Para Walker (2010), cadeia varia ao longo de duas dimensões analíticas: 1tamanho e 2- heterogeneidade. Por tamanho, o autor enfatiza que uma cadeia pode variar de uma pessoa interagindo com uns poucos artefatos até milhares de pessoas e artefatos participando de uma história de vida social. Por heterogeneidade, explica que cadeias exibem diversidade social tanto na sua corrente de atividades, quanto na composição de um grupo social.

Essa manifestação material de relações sociais heterogêneas interage e comunica o papel que elas manifestam na identidade social do grupo, tanto das pessoas pertencentes a determinado grupo, quanto das pessoas que pertencem a grupo(s) distinto(s). Importante salientar o que Walker (2010) chamou de "poder social” e como ele se exerce no grupo, impedindo ou habilitando atividades de outros grupos, os níveis de interação e os artefatos a serem interagidos. Tudo isso expresso em tipos de relações intergrupos em cadeias.

Ao evocar conceitos clássicos para a arqueologia como escolhas técnicas, cadeia operatória, sistema técnico e cadeia comportamental, mostramos que existe uma ampla gama de relações técnicas e materiais no e entre grupos sociais que permitem, por meio do estudo do registro arqueológico, compreender em parte aquilo que Schiffer e Skibo (2008) e Walker (2010) chamaram de "cadeias" ou Ingold (2000) chamou de "taskscape" e que podem ser sintetizadas como redes de tarefas sociabilizadas que hoje se manifestam pelos materiais arqueológicos. 
1.6.2 Identificando a produção e distribuição dos fragmentos de cerâmica no contexto arqueológico

Informações geográficas sobre os materiais arqueológicos, tais como o local de manufatura, as circunstâncias em que foram processados, as matérias-primas constituintes e a sua distribuição ou transporte, exigem uma gama de técnicas analíticas.

Em primeiro lugar, é necessário definir os conjuntos de artefatos (assemblages) que são encontrados num mesmo contexto (JOYCE; POLLARD, 2010). Essas unidades empíricas variam em termos de situação de recuperação ${ }^{24}$, das suas condições físicas ${ }^{25}$, de sua escala espacial ${ }^{26}$ e da duração estimada de sua formação (GRAVES, 2001). Atentase sobre os efeitos das variáveis de processos de formação cultural e natural que atuam sobre as assemblages, incluindo períodos de ocupação e reocupação, intensidades dessas ocupações e das atividades ali exercidas, processos de abandono e eventos pósdeposicionais (BUTZER, 2006).

Assim, consideramos assemblages como um grupo de objetos recorrentes em um determinado tempo e lugar e que representam a soma de atividades humanas e processos de transformação (REFREW; BAHN, 2008). É intrínseco ao conceito, sua associação com a cultura material, as características geográficas dos locais de recuperação e da faixa cronológica onde o domínio comportamental atuou.

A organização intrassítio das assemblages pode se dar pelas diferenças, semelhanças e sobreposição dos conjuntos deposicionais. Usando como base a teoria dos conjuntos Carr (1984) formulou uma organização com base em quatro conceitos: 1conjuntos como grupos de entidades; 2- membros ou elementos dos conjuntos (entidades agrupadas); 3- atributos (estados característicos que as entidades possuem); 4- e a lista de atributos que as entidades de um conjunto devem compartilhar, em parte ou totalmente, para pertencer ao conjunto.

Esses conceitos realizam a permutação entre os domínios comportamentais e arqueológicos, objetivando descrever a organização das atividades e as transformações em sua organização. Assim, um sítio pode ser constituído por conjunto (s) de depósito (s) arqueológico (s) com vários membros que, por sua vez, possuem tipos de artefatos formados por uma gama de atributos. Alguns conjuntos podem estar próximos ou até

\footnotetext{
${ }^{24}$ Se foram recuperadas por meio de escavação de subsuperfície, coletadas em superfície, em áreas aradas etc.

${ }^{25}$ Se altamente fragmentadas, parcialmente fragmentadas, parcialmente reconstituíveis, reconstituíveis ou inteiras.

${ }^{26} \mathrm{Se}$ formam vários componentes de um sítio, um único sítio ou múltiplos sítios.
} 
sobrepostos, mas não compartilham atributos comuns de seus artefatos. Quando isso ocorre, diz-se que não estão associados na dimensão comportamental. Quando conjuntos distintos estão próximos ou sobrepostos e compartilham de alguns atributos de seus artefatos, eles podem estar associados por meio do comportamento e envolver áreas de atividades, refugos secundários, setores domésticos etc. (CARR, 1984).

Assim, uma maneira de estudar a produção e distribuição dos fragmentos de cerâmica, a exemplo, seria pela identificação e comparação de seus atributos. Cerâmicas pintadas e sem pintura, encontradas em assemblage $(s)$ poderiam realçar as diferenças na produção das classes funcionalmente distintas de vasos, sejam aquelas utilizadas para cozinhar ou armazenar (funcionais) ou aquelas usadas para servir, exibir ou participar de rituais, apelando para o desempenho visual (GRAVES, 2001; SCHIFER; SKIBO, 2008).

Além das questões de desempenho funcionais, visuais ou simbólicos, os diferentes atributos obtidos por meio das classes cerâmicas podem evidenciar aspectos de sua manufatura que nos permitem inferir se a produção foi local ou não. Os melhores resultados ocorrem quando há o cruzamento das características morfológicas, tecnológicas e de desempenho das cerâmicas.

O enfoque a ser dado na análise dos fragmentos permeia o conceito de cadeia operatória e comportamental, definindo as áreas de aquisição e coleta de matéria-prima para confecção dos vasos, os possíveis lugares de confecção, a preparação da matériaprima, ocorrendo ou não a inserção de tempero, a forma dada aos vasos, o acabamento superficial com ou sem decoração, uso, intercâmbio e processos pós-deposicionais (GRACE, 1996; SCHIFFER; SKIBO, 2008).

Nesse enfoque, os fragmentos cerâmicos coletados foram, primeiramente, analisados à luz da metodologia desenvolvida por Robrahn (1991) e por Faccio (1992). Partindo para a classificação dos atributos tecno-estilístico-morfológicos dos fragmentos recuperados na área da pesquisa, intentamos obter as seguintes informações:

1- Número da peça em estudo e o setor ou a localização da coleta do material. Essa informação é imprescindível para mapear a distribuição intrassítio dos fragmentos;

2- A primeira classe de atributos refere-se ao tipo da peça. Essa análise permite averiguar qual parte fragmentada do antigo vaso foi recuperada;

3- A segunda classe de atributos considera os tipos de antiplásticos associados aos fragmentos cerâmicos. Para Faccio (1998, p.134), o antiplástico foi utilizado para "neutralizar a plasticidade da argila, dar condições para boa secagem e queima, aumentar 
ou diminuir a resistência do choque térmico ou mecânico, diminuir ou aumentar a porosidade ou permeabilidade".

Utilizando a definição de Faccio (1998) como premissa, acrescentamos que quando ocorre a inserção de material não plástico na massa de argila, essa ação implica em intencionalidade de produção, pressupondo um estágio tecnológico avançado, onde os artesãos preveem o comportamento da cerâmica a partir da avaliação da matéria-prima (GOULART, 2004). Todo material adicionado intencionalmente à argila para lhe dar mais resistência e durabilidade durante e após a queima foi nesta tese chamado de “tempero".

Inserir em quantidade ideal tempero na argila consiste em escolha técnica com efeitos concretos sobre as propriedades formais do vaso, implicando em desempenho nas atividades subsequentes (SKIBO; SCHIFFER; 1997). Por exemplo, vasos que apresentam antiplástico mineral de quartzo caracterizam-se por serem mais porosos e leves em relação aos vasos com tempero de caco moído. Isto porque o "quartzo sofre uma grande variação de tamanho devido à expansão térmica durante a queima" (JACOME, 2006, p.124). “As cerâmicas feitas de quartzo apresentam fragilidade para o cozimento, sendo reservadas ao armazenamento de líquidos" (Ibidem, p.125) ou, então, para servir bebidas e alimentos.

A inserção de tempero implica em desempenho utilitário que está diretamente relacionado à atividade específica do vaso. Para se ter alta resistência ao choque térmico ou para não rachar no fogo, a panela deve ter uma adição de tempero como opção técnica para o uso repetido do fogo, como aquelas destinadas a cozinhar alimentos (SKIBO; SCHIFFER, 2008).

O estudo do antiplástico e da inserção do tempero não implica somente em questões funcionais, mas também, na identificação geográfica de sua coleta, o que é de suma importância para inferir se a captação de matéria-prima e a produção foram locais ou externas. Estudos etnoarqueológicos feitos por Silva (2008) mostram que entre os Assurini do Xingu, as escolhas das melhores jazidas de argila eram aquelas que envolviam uma argila com aspectos mineralógicos e granulométricos ideais para a produção de sua cerâmica. Nem sempre essas fontes estão disponíveis próximas às aldeias. Pode ser que incursões a rios e córregos, com distâncias variáveis da aldeia, ocorressem para a captação de matéria-prima. No entanto, muitas vezes a disponibilidade de um bom suprimento de barro pode ser um fator condicionante da escolha do lugar para a instalação do assentamento (LIMA, 1997). 
Torna-se de importância vital o mapeamento de fontes de argila nas proximidades dos sítios arqueológicos, com o propósito de comparar a composição mineralógica entre os fragmentos de cerâmica e as possíveis áreas de captação de matéria-prima. Por meio dessa abordagem poderemos determinar a área geográfica de produção de algumas cerâmicas e, possivelmente, excluir outras dessa localidade (GRAVES, 2001).

Cerâmicas com antiplásticos ou adição de temperos não encontrados na localidade podem refletir duas circunstâncias:

1- $\quad$ as fontes de argila ou tempero eram captadas em áreas relativamente distantes da antiga aldeia ou

2- 2- existiam interações sociais pretéritas que possibilitavam o intercâmbio desses produtos. Ponderamos que essas análises devem ser realizadas com técnicas arqueométricas para que os resultados dessas inferências sejam satisfatórios.

4- A terceira classe refere-se ao tamanho e à forma do antiplástico ou tempero. A proposta de análise considerou apenas o antiplástico ou tempero de maior tamanho.

5- A quarta classe refere-se à espessura da peça. Julgamos oportuno nessa etapa o cruzamento dos dados, relacionando a quantidade de antiplástico ou tempero disposto na argila com a espessura das paredes dos fragmentos.

Com base nos estudos de Brochado e La Salvia (1989), classificamos a pasta em três tipos: 1- plástica, na qual existiu o predomínio da argila sobre o antiplástico ou tempero; 2- intermediária, que apresentou certa equivalência entre o antiplástico ou tempero e a argila; 3- dura, quando houve o predomínio do antiplástico ou tempero em relação à argila. A análise da relação entre a quantidade de antiplástico e argila foi feita a partir da quebra de parte dos fragmentos cerâmicos em pedaços de aproximadamente 1 $\mathrm{cm}$, sendo feita a visualização espacial da presença de argila em relação ao antiplástico ou tempero.

O entendimento da relação entre tipo de pasta e espessura da parede pode nos mostrar as preferências de confecção das vasilhas por parte do grupo que as criou, em uma primeira etapa, podendo evoluir para um melhor entendimento da relação do projeto de confecção de uma vasilha com seu desempenho funcional.

6- A quinta classe aborda o tratamento de superfície do lado interno e externo dos fragmentos cerâmicos. Nessa categoria, foram observadas e descritas as seguintes variáveis: alisado interno/externo, alisado interno/engobo externo, engobo interno/externo, engobo interno/pintura externa, pintura interna/engobo externo, alisado 
interno/pintura externa, pintura interna/alisado externo, pintura interna/externa, alisado interno/inciso externo, inciso interno/alisado externo (FACCIO, 1992).

Nota-se, como veremos em outra seção, que o uso de engobo e pintura não é característico da tradição aratu-sapucaí. Algumas ocorrências de fragmentos com essas características podem trazer à tona algumas questões: 1- as cerâmicas engobadas e/ou pintadas podem ser atribuídas a outra região de produção? 2- se não foram produzidas pelos habitantes do antigo assentamento, por quais meios sociais elas foram parar lá? 3existe a possibilidade de uma reocupação desse sítio por outro grupo que produzia diferentemente a cerâmica?

7- A sexta classe considera e examina a forma das bordas. Foram identificadas as seguintes formas de bordas para os sítios estudados: borda direta, extrovertida, contraída, cambada, carenada e introvertida.

8- A sétima classe analisa a forma e a possível função das antigas vasilhas. É nessa etapa que ocorrem as reconstituições de bordas dos recipientes cerâmicos, utilizando o método gráfico a partir dos fragmentos mensuráveis.

Dentro desse contexto, o estudo do material cerâmico toma como "unidade básica, o recipiente cerâmico enquanto artefato, fonte de informação que conduz o olhar do pesquisador às atividades cotidianas do grupo indígena pretérito" (ROBRAHN, 1996, p.78). A ideia é reconstituir as bordas a dimensões apropriadas, aliando-se isto à leitura de seus atributos tecnológicos, morfológicos e estilísticos.

Os aspectos morfológicos das vasilhas foram obtidos pelas reconstruções gráficas das bordas. Vale ressaltar que essas reconstruções servem para indicar algumas possibilidades de forma e dimensões dentro de cada categoria, não sugerindo a exatidão da forma que as vasilhas teriam tido (BROCHADO; MONTICELLI, 1994), o que, segundo os autores, não prejudica esse tipo de classificação, pois a preocupação é "com a reconstrução da funcionalidade das vasilhas" (Ibidem, 1994, p.109).

A metodologia de análise tradicional dos fragmentos cerâmicos apresentada acima deve ser complementada por técnicas arqueométricas, contribuindo com o entendimento dos processos relacionados ao beneficiamento da argila, dos procedimentos técnicos adotados pelos artesãos a correlação das pastas cerâmicas com as jazidas de argila prospectadas em campo, os minerais utilizados para a confecção da pasta e para o seu revestimento externo, no contexto da produção dos vasos cerâmicos.

\subsubsection{Identificando a produção e distribuição dos líticos lascados e polidos}


A análise dos materiais líticos focou nas informações geográficas a respeito dos locais de aquisição de matéria-prima, locais de preparo da matéria-prima, preparação e manufatura da matéria-prima e áreas de atividades/funcionais intrassítio.

A aquisição da matéria- prima para a confecção de ferramentas líticas está associada à capacidade de aquisição e transporte dos materiais. Dimensões e quantidade, peso e distância, boa fratura e dureza suficiente para percussão lítica foram ponderados durante a coleta desses materiais e serão objeto de análise (FACCIO, 1998; LUZ, 2010; SCHIFFER; SKIBO, 1997).

Uma vez coletada a matéria-prima, a espacialidade dos processos de produção, ou seja, dos locais específicos para cada processo de confecção dos instrumentos, deve ser rastreada. Esses locais podem ser traduzidos como áreas de atividades e comportamentos que caracterizam o papel desempenhado por determinado sítio (BINFORD, 1983). Nessa etapa, a característica da distribuição dos artefatos intrassítio deve ser verificada.

A manufatura do material lítico envolve uma sequência gestual que deve ser verificada durante a análise do material. Nesta etapa, é necessário compreender se a rocha sofreu lascamento, polimento e/ou picoteamento. Também é necessário compreender se se trata de um núcleo onde está sendo efetuada a debitagem ou se trata de lascas, estilhas e outros que foram debitados (GRACE, 1996).

Dividiremos a tecnologia de manufatura do material lítico lascado em: 1redução primária; 2- redução secundária e 3- tipologia. Redução primária está relacionada à redução dos nódulos e núcleos. O tipo de planos de percussão e as características dos negativos preservados permitirão visualizar parte da tecnologia envolvida. A redução secundária relaciona-se com a produção de lascas iniciais, a partir de núcleos "e incluem tais aspectos como tecnologia de lâminas e de lascas" (GRACE,1996, p. 9). Nessa etapa serão analisados os dados métricos, morfologia das peças e características do talão. A tipologia está relacionada à produção de ferramentas e às técnicas de retoque. As etapas de análise de redução secundária serão aplicadas à tipologia, que será complementada com a descrição da façonnage ${ }^{27}$ e dos retoques (GRACE 1996; LUZ, 2010).

Trata-se de modificar e criar relações tridimensionais (orientação de planos, simetria ou oposição entre formas e volumes etc). Esse trabalho deve culminar na obtenção de um objeto que responda aos conceitos preexistentes que determinam a relação entre forma, funcionamento e função, para cada categoria de utensílio. Durante o trabalho de façonnage, cada nova retirada estabelece novas relações volumétricas entre 
Os líticos polidos geralmente resultam de um processo de lascamento, picoteamento e polimento. "Como partir para o polimento diretamente tornaria o trabalho excessivo, utilizava-se o picoteamento para ajudar a formatar as peças, mesmo correndo o risco de perdê-las pela quebra" (SOUZA, 2008, p.113).

As "marcas" desse processo de fabrico podem ser distinguidas durante a análise do material. Assim, objetos polidos "constituem, na maior parte dos casos, duas fases de fabricação de um utensílio, o qual apresentará, portanto, partes bem polidas e outras nas quais o picoteamento é ainda visível (LAMING-EMPERAIRE, 1967, p.121).”

A análise das etapas de confecção desse grupo de material lítico deve reuniras seguintes categorias: 1- morfologia; 2- croqui no plano principal e os dois cortes; 3forma, atentando-se para as pequenas ações de confecção do objeto; 4- descrição das superfícies e dos bordos diferenciados e 5- a quantidade de córtex (em porcentagem) ainda existente no instrumento (LAMING-EMPERAIRE, 1967).

Concomitante à análise laboratorial, a abordagem sobre função deve conectar as características gerais dos objetos arqueológicos manufaturados com sua distribuição intrassítio. A função do sítio só pode ser parcialmente inferida quando se descobre o uso específico das ferramentas, que possibilitarão identificar locais de atividades e interpretar o tipo do sítio.

No caso do material lítico, a tecnologia de redução primária, redução secundária e tipologia, assim como as características do lítico polido, permitirão fazer inferências a respeito do uso desse material. Aliado ao uso, quando mapeado nos locais de escavação, os mesmo nos permitirão inferir sobre as áreas de atividades (BINFORD, 1983).

todas as partes do artefato. Na literatura europeia, a aplicação do termo façonnage (e portanto, o reconhecimento dessa etapa no interior de um método de lascamento) tendeu a restringir-se aos objetos que apresentam mais de uma face trabalhada (FOGAÇA, 2003, p. 13). 
CAPÍTULO 2

A OCUPAÇÃO INDÍGENA REGIONAL: ELEMENTOS PARA UMA SÍNTESE HISTÓRICA COMPARATIVA 
Estudos arqueológicos realizados na bacia hidrográfica do rio Grande e Alto Paraná, sobretudo aqueles concernentes às bacias do Turvo-Grande, Baixo Pardo-Grande, Pardo-Grande, Sapucaí-Grande e São José dos Dourados, ambas localizadas na região norte do Estado de São Paulo, vêm apresentando um quadro importante e instigante sobre a relação mantida entre grupos agricultores que confeccionavam a cerâmica.

Estas cinco bacias hidrográficas formam o nosso Contexto Arqueológico Regional de estudo, que se apresentará no decorrer desta tese com a sigla CAR. O CAR forma um extenso território limitado ao norte pelo rio Grande, ao oeste pelo rio Paraná, a leste pelo rio Sapucaí e ao sul pelo rio São José dos Dourados e pela nascente do rio Turvo.

Tradicionalmente, os grupos pré-coloniais que habitaram o CAR foram correlacionados a diferentes tradições ceramistas ${ }^{28}$, sendo elas a tupiguarani, aratu e uru, apontando alguns limites físicos do estado de São Paulo, como áreas de fronteira e/ou interação cultural entre essas tradições (ROBRAHN-GONZÁLEZ, 2000). Marcos geográficos, dispersão de fragmentos cerâmicos e cronologia vêm auxiliando na compreensão da ocupação das diferentes tradições arqueológicas em nossa região de estudo.

Alguns arqueólogos que atuaram e atuam em pesquisas posteriores ao PRONAPA ${ }^{29}$, ponderaram que o termo "tradição arqueológica", formulado pelo programa nas décadas de 1960 e 1970, apresentou algumas limitações para as pesquisas arqueológicas contemporâneas, entre elas: o tratamento da cultura de povos pretéritos de uma maneira artificial, ignorando informações históricas e etnográficas (NOELLI, 19992000); a separação entre materiais arqueológicos e grupos linguísticos (MORAIS, 19992000) e a rotulagem de um passado rico e dinâmico para um termo fixo e englobante (LIMA, 2011).

Nesta tese, não descartaremos a reflexão destes autores sobre as limitações do termo adotado nas pesquisas arqueológicas brasileiras. No entanto, a leitura aqui presente visa resgatar o que já foi produzido na região, e o termo tradição é empregado na maioria dessas pesquisas. Como bem salientou Moraes (2008, p.98), "somos herdeiros destas

\footnotetext{
${ }^{28}$ O termo tradição foi formulado pelo Programa Nacional de Pesquisas Arqueológicas (PRONAPA), sobretudo nas décadas de 1960 e 1970, para atender a preocupação em criar grandes complexos culturais arqueológicos, dissociados dos dados de natureza etnológica, com o objetivo central de traçar sequências cronológicas e montar quadros de difusão cultural. Essas tradições regionais eram constituídas por números variados de fases, estas definidas pela sequência seriada (método Ford), caracterizada por tipos específicos de artefatos líticos, cerâmicos, padrões de povoamento e de sepultamento (BROCHADO et. al., 1968).

${ }^{29}$ PRONAPA (Programa Nacional de Pesquisas Arqueológicas).
} 
classificações e certamente temos que estabelecer com elas um diálogo". Uma discussão sobre os Sistemas de Povoamentos Regionais inseridos no CAR foi realizada no capítulo 4.

Para a confecção de um quadro arqueológico regional de referência, selecionamos trabalhos de arqueologia acadêmica e preventiva que detalharam atividades de campo e laboratoriais nas cidades de Ouroeste, Olímpia, Barretos, Guaíra, Guaraci, Paulo de Faria, Icém, Cardoso, Monte Alto e Meridiano, estado de São Paulo. Em suma, a descrição desses sítios arqueológicos representa o registro de atividades e ocupação humana em uma diversidade de ambientes, cujo traço que os une é o de tratar-se de antigas comunidades ceramistas que habitaram e se construíram relações na região da Bacia do Rio Grande e Alto Paraná, em tempos pretéritos.

Até o momento, os dados arqueológicos oferecidos para os sítios cerâmicos localizados nesta área consideram essa região como palco de ocupações diferenciadas, refletindo contexto extrarregional com influência da tradição tupiguarani, tradição aratu e tradição uru (AFONSO; MORAES, 2007; FERNANDES, 2011; MORAIS, 1999-2000; ROBRAHN GONZÁLEZ, 2000; RODRIGUES, 2008).

\subsection{Contexto Arqueológico Extrarregional}

\subsubsection{A Região Centro-Oeste}

De um modo geral, é possível associar boa parte dos sítios arqueológicos instalados no norte do estado de São Paulo aos grupos ceramistas que ocuparam a região Centro-Oeste brasileira. Estes grupos foram extensamente estudados por Wust (1983; 1991) e Robrahn-González (1996) e serão aqui suscintamente descritos. Neste item, confeccionaremos um quadro informativo para apresentar a 1- cronologia destas ocupações, 2- suas características materiais e espaciais e 3- sua área de ocorrência espacial $^{30}$.

Em sua dissertação de mestrado intitulada “Aspectos da ocupação pré-colonial em uma área do Mato Grosso de Goiás - tentativa de análise espacial”, publicada no ano de 1983, a arqueóloga Irmhild Wust realiza estudos de sítios arqueológicos filiados à tradição aratu (fase Mossâmedes). Recolhendo informações sobre cronologia em Schmitz

\footnotetext{
${ }^{30}$ Enfatizando suas movimentações territoriais e suas interações com outras tradições arqueológicas.
} 
(1976, p.7-8,) estes sítios apresentaram datações por C14 numa faixa cronológica que se estende de 895 +- 90 A.P até 1.140 +-90 A.P, situando esta tradição dentro de um universo cronológico que vai do século IX ao XI D.C.

A área de ocorrência desta tradição no Centro-Oeste do país se estende desde o rio Corumbá, afluente do Paranaíba, até os cursos médios e altos do rio Claro e rio Caiapó, afluentes do Araguaia. Representa uma extensão Leste-Oeste de aproximadamente 350 km. A maior parte destes sítios está situada na microrregião do "Mato Grosso de Goiás" caracterizada por apresentar cobertura de matas tropicais subcaducifólias e solos férteis (WUST, 1983).

As características cerâmicas dessa tradição abrangem jarros cônicos, recipientes globulares e semiglobulares com borda direta, e com menor frequência os recipientes conjugados. Na maior parte dos casos apresentam tratamento liso, podendo ocorrer decoração plástica, geralmente representada por linhas incisas paralelas à borda. Apresenta, predominantemente, antiplástico de origem mineral.

As características espaciais dos sítios arqueológicos classificados como tradição aratu, fase Mossâmedes, foram descritos com base em sua implantação no relevo e aspectos morfológicos. Os sítios-habitação estão instalados preferencialmente em relevo ondulado, sobre meia encosta de colina, havendo certa tendência a ocupar também o topo de colina, coincidindo com um ótimo campo de visão ${ }^{31}$. A orientação da vertente principal dos sítios está situada, predominantemente, do lado norte, sendo menos frequentes aquelas ocupações das vertentes sul e leste. Quanto à proximidade das diversas categorias dos cursos de água, Wust $(1983 ; 1991)$ não observou nenhuma tendência dos sítios habitações, podendo eles situarem-se nas proximidades de cursos de água e graus de piscosidade de maior ou menor volume.

Quanto aos aspectos morfológicos dos sítios, as plantas de sete sítios evidenciaram deposição em forma de um único anel, composto por concentrações cerâmicas, mantendo espaços intervalares entre si e que circunscrevem um grande espaço interno, em geral não apresentando evidências arqueológicas em superfície. Alguns sítios apresentaram deposição por dois anéis concêntricos. As dimensões dos sítios com deposição anular variam de 155 x 136m (GO-RV-31) a 560 x 420m (GO-RV-61),

\footnotetext{
${ }^{31}$ Salienta Wust (1991) que alguns destes sítios instalados em topo de morro situam-se no divisor de águas entre as bacias do Araguaia e Paranaíba, o que pode representar uma possível conotação defensiva destes sítios, pois esta região é descrita como área de fronteira cultural entre grupos portadores de tradições ceramistas diferentes.
} 
apresentando a distribuição predominante dos sítios um diâmetro máximo de 300 a 400m. "Para os sítios que forneceram plantas completas das evidências de superfície, o número de concentrações cerâmicas varia de 11 a 93" (WUST, 1991, p. 106), sendo as ocupações formadas por duas a cinco concentrações cerâmicas, aleatoriamente dispostas no relevo, classificadas como sítios de atividades específicas.

Wust (1991), ao escavar algumas áreas de concentrações cerâmicas, avaliou que as mesmas correspondiam a unidades habitacionais. A autora partiu do pressuposto de que o refugo evidenciado remeteu a atividades diversificadas e associadas a artefatos utilizados para as tarefas do cotidiano como cozinhar e consumir alimentos. Ponderou que, em alguns casos, a dimensão destas concentrações cerâmicas se assemelharia à dimensão de unidades habitacionais plurifamiliares de grupos indígenas do Brasil Central.

Ao final de seu extenso estudo sobre sítios arqueológicos inseridos na região do Mato Grosso de Goiás, Wust $(1983 ;$ 1991) formula uma série de hipóteses referentes à história de vida destes assentamentos. Entre as principais, elencamos:

1- No período inicial de ocupação $\operatorname{aratu}^{32}$, o tamanho dos sítios, bem como a ausência de sítios pequenos, indicam certa estabilidade dos contingentes populacionais e ausência de pressões externas;

2- Em níveis temporais posteriores ${ }^{33}$, registraram-se grande diversidade no tamanho dos sítios e maior frequência de sítios que somente apresentam um segundo anel iniciado. Para os sítios menores, sugere-se que os deslocamentos poderiam ter sido acompanhados por cisões ou reagrupamentos de comunidades. A presença de anéis concêntricos iniciados e a pouca profundidade da camada arqueológica remetem a um menor grau de permanência. Neste período, há a ocorrência de sítios com conotação defensiva, sugerindo uma mudança no comportamento espacial, eventualmente associada a pressões de outros grupos, instalados, sobretudo, no limite oeste da área de estudo.

3- O último período para esta tradição na área de estudo de $\mathrm{Wust}^{34}$ (1983) coincide parcialmente com as primeiras penetrações do elemento colonizador, mostrando uma acentuada nucleação dos sítios no sudoeste da área-piloto, bem como redução sensível no tamanho de alguns sítios. Para Wust (1991), estes dados permitem levantar a hipótese de uma redução demográfica por conta do contato interétnico.

\footnotetext{
${ }^{32}$ Níveis temporais 1 e 2 estabelecido por Wust (1983).

${ }^{33}$ Níveis temporais 3 e 4 estabelecido por Wust (1983).

${ }^{34}$ Nível temporal 5 estabelecido por Wust (1983).
} 
Os níveis temporais estabelecidos por Wust (1983) baseiam-se na ocorrência similar do antiplástico que formam os conjuntos cerâmicos. Neste caso, os cinco primeiros níveis temporais pertencem a uma mesma tradição arqueológica associada aos Aratu. Já o nível 6 pertence a outra tradição, associada aos Uru, e será descrito em separado. Ressaltamos que os artefatos do nível 6 aparecem de forma intrusiva também nos níveis 2, 3 e 4, indicando interação e contemporaneidade entre estes grupos (SOARES, 2012; WUST, 1983).

A Figura 2 apresenta todos os sítios trabalhados por Wüst (1983) plotados em seus níveis de temporalidade relativa.

Figura 2 - Localização dos sítios arqueológicos segundo nível temporal

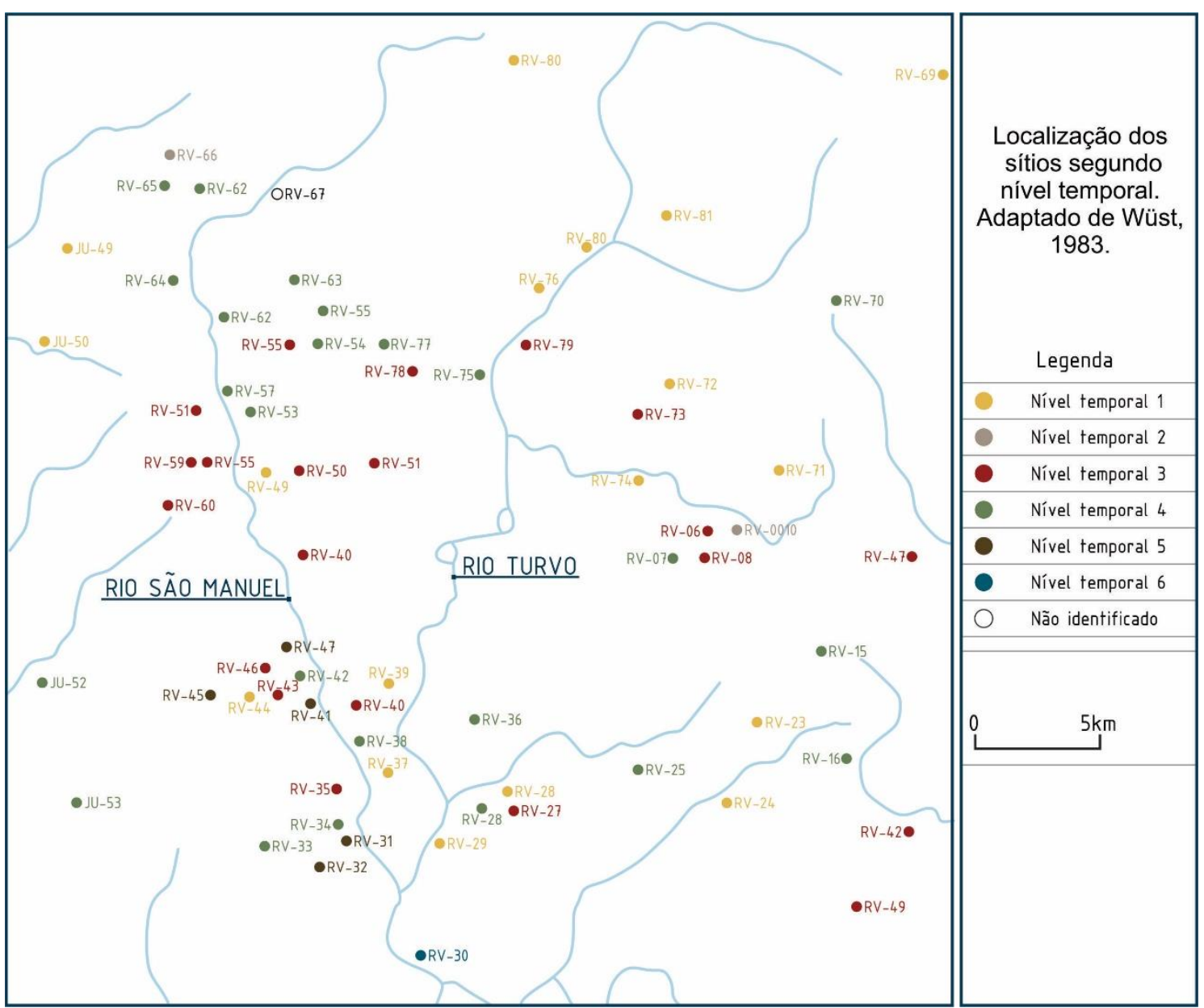

Fonte: Wust (1983, p.219) adaptado por Soares (2012, p.51). Confecção: Maria Frizarin.

Complementando os dados geoambientais e arqueológicos de Wust para a região de Mato Grosso de Goiás, Juliana Soares (2012; 2013) realiza importante discussão sobre a tradição aratu e seu padrão de assentamento associado a zonas de tensão ecológica. 
Apesar de sua dissertação inicialmente propor uma discussão para a tradição aratu abrangendo diversas regiões do Brasil, iremos enfatizar apenas aquela referente ao estado de Goiás, que é de maior interesse para nossa pesquisa.

O estado de Goiás apresenta as datações mais antigas, bem como, os sítios arqueológicos de maior complexidade dentro do universo da tradição aratu. Segundo a autora, as características diferenciadas colocam a região como uma zona central de consolidação da tradição, onde se percebe maior antiguidade das ocupações e um maior desenvolvimento cultural. De maneira geral, as áreas periféricas não conformam as grandes aldeias circulares observadas em Goiás e, quando o fazem, aparecem estas de maneira isolada.

Os estudos de Soares culminaram na construção de um modelo de subsistência para esta tradição e demonstrou que as áreas de "mata eram procuradas por apresentar solos férteis que deveriam garantir a manutenção dos cultivos agrícolas, enquanto o cerrado, no sentido estrito, devia servir como importante zona de coleta e caça" (SOARES, 2013, p.74).

Com base neste dado, a autora explicita que a maior desenvoltura desta tradição para a região centro-sul de Goiás se explica, em parte, pela densa mata atlântica de interior ou o Mato Grosso de Goiás, que garantiu abundância de recursos de maneira permanente. Por sua vez, as zonas periféricas, em meio ao cerrado, não garantiram abundância em cobertura florestal, "fazendo com que o grupo tenha que se fragmentar, a fim de dominar os capões de mata dispersos, sobretudo as Matas de Galeria, gerando assim ocupações mais rarefeitas, com menor densidade populacional” (Ibidem, 2013, p. 75).

Outra importante tradição arqueológica que se manifesta no Centro-Sul do país é a tradição uru. Robrahn-González (1996), recolhendo informações sobre cronologia em Schmitz (1982) e Wust (1990), pondera que os sítios filiados a esta tradição apresentaram datações por C14 numa faixa cronológica que se estende de 895 +- 65 d.C. a 1260+-70 d.C., situando esta tradição dentro de um universo cronológico que vai do século IX ao XIII de nossa era.

A área de ocorrência desta tradição situa-se no Centro-Oeste do país e os sítios estão localizados na bacia do rio Araguaia, sobretudo na sua margem esquerda, e na bacia do Rio São Lourenço, localizado mais a oeste.

Para Robrahn-Gonzalez (1996), a distribuição de sítios arqueológicos filiados à tradição uru apresenta uma divisão geoambiental importante, podendo ser divididos em duas áreas. A primeira, reúne sítios do alto Araguaia e do médio/alto São Lourenço, 
pertencentes a unidade de relevo do Planalto da Bacia Sedimentar do Paraná, apresentando vegetação de cerrado e solos com fertilidade baixa a fortemente limitada. A segunda área reúne sítios da margem direita do rio Araguaia, onde predominam a Planície do Bananal e a Depressão do Araguaia-Tocantins, apresentando vegetação formada por manchas que mesclam o cerrado e áreas de tensão ecológica. Segundo a autora, as duas áreas se diferenciam por uma maior diversidade geomorfológica e vegetal para os sítios à direita do Araguaia, enquanto os sítios à sua esquerda contariam com um ambiente mais homogêneo.

Genericamente, a produção cerâmica para esta tradição caracteriza-se por apresentar vasilhas simples, algumas vezes com banho vermelho e entalhes no lábio. Suas características mais marcantes são o emprego do antiplástico cariapé, formas de tigelas e pratos com base plana, algumas apresentando ângulo de $90^{\circ}$ e bordas acasteladas (WUST, 1983).

Uma análise pormenorizada de Robrahn-González (1996) sobre a cerâmica uru indica um largo predomínio de grandes vasilhames infletidos, cujas características permitem supor uso cotidiano e doméstico, vinculado ao armazenamento e/ou estocagem de conteúdos de considerável peso e proporção. Constituem, ainda, as peças que se mostram menos permeáveis à introdução de elementos externos.

Variações entre os treze sítios reunidos nesta tradição permitiram que a autora os dividisse em dois grupos, segundo sua distribuição geográfica: os localizados no vale do Araguaia apresentam coleções cerâmicas diversificadas, além da presença mais expressiva de elementos que remetem a contatos com grupos externos (portadores de cerâmica tupiguarani); já os sítios localizados a oeste, no vale do São Lourenco, apresentam menores índices de variação e de elementos externos, sugerindo tratarem- se de sítios mais "puros” (ROBRAHN-GONZÁLEZ, 1996).

Com base nos dados cronológicos, características cerâmicas e aspectos geoambientais de implantação dos sítios, Robrahn-Gonzalez considera que a ocupação mais antiga da Tradição Uru teria sido processada primeiramente na porção oeste do Centro-Oeste brasileiro, expandindo-se, posteriormente, para a porção leste da supracitada região. Neste processo, contatos e interações interculturais poderiam ter gerado a emergência de novos grupos culturais, como veremos adiante.

De maneira geral, os sítios arqueológicos caracterizados como pertencentes à tradição uru encontram-se em planícies baixas, próximos a lagos, distando destes de 0 a $211 \mathrm{~m}$ ou estão instalados sobre suaves declives com uma distância de 70 a 140 m do 
córrego mais próximo. Indicam morfologia anular com um, dois ou até três anéis concêntricos, tendo uma média de 41 concentrações de materiais arqueológicos. Para esta tradição também foi registrada deposição arqueológica configurada de maneira linear simples ou às vezes em fila dupla, podendo alcançar uma extensão de até $934 \mathrm{~m}$ (ROBRAHN-GONZÁLEZ, 1996; WUST, 1983).

Sítios arqueológicos apresentando deposição linear foram estudados por Wust (1983) e serão detalhados aqui, pelo fato de apresentarem configuração semelhante ao sítio arqueológico Menino Jesus, alvo de nossas pesquisas.

Desta forma, seis sítios apresentaram concentrações cerâmicas simples em número de uma, duas ou mesmo seis, sendo neste caso dispostas linearmente. No sítio GO-RV-77, as maiores distâncias entre concentrações de material são de 264 e $602 \mathrm{~m}$, atingindo o sítio um comprimento de $934 \mathrm{~m}$ e uma largura de $119 \mathrm{~m}$ na sua parte central, onde se encontram algumas concentrações agrupadas. Os sítios GO-RV-54 e GO-RV-77 apresentaram ocorrência de poucos fragmentos cerâmicos e de artefatos líticos isolados, na vertente oposta. Sugere-se para estes sítios uma ordenação linear de concentrações cerâmicas, paralela a ambas as margens de um curso de água.

Para a autora, estas estruturas singulares ou alinhadas ao longo de um curso d'água podem ser interpretadas como sítios de atividade limitada. Assim:

Os seguintes vestígios arqueológicos: o reduzido tamanho das concentrações, a pequena quantidade de artefatos e suas características, a ausência de modificação na coloração do solo e a pequena espessura do refugo indicam que estes sítios foram ocupados por segmentos de uma comunidade maior, que ali executaram atividades específicas por um tempo não muito prolongado [...] trata de sítios de atividade limitada, a partir dos quais somente poucos recursos são aproveitados [...] localizados muito próximos a um curso d'água, na parte baixa ou média baixa de uma vertente nas imediações da faixa da mata ciliar, onde os solos apresentam uma alta fertilidade natural [...] Poder-se-ia interpretar o padrão alinhado das concentrações como resultado da ocupação subsequente por um mesmo segmento da comunidade ou da presença simultânea de dois ou mais, separados por distâncias que em um caso (GO-RV-77) alcançam até $602 \mathrm{~m}$ [...] devem ser considerados como espaços articulados a sítios-habitação. (WUST, 1983, p. 266-267268).

Apresentadas as características que julgamos serem essenciais para estas duas tradições, iremos discorrer brevemente sobre a hipótese de Robrahn-González (1996) 
quanto a uma possível fusão entre a tradição aratu e uru por volta do século XI da Era Cristã.

Pondera a autora que neste período os grupos de leste, detentores da cerâmica aratu, mantiveram contato com os grupos de oeste, detentores da cerâmica uru. Este contato envolveria a circulação de informações e de pessoas, materializadas nas pesquisas arqueológicas, como mudanças nas escolhas técnicas da confecção cerâmica, no primeiro caso, e concentração de material uru, próximos e/ou no interior das aldeias caracterizadas como aratu, para o segundo caso. Neste último caso, sugere a autora, trata-se de uma forma mais complexa de contato cultural, onde a manutenção da forma tradicional de se fazer cerâmica entre dois grupos poderia resultar num marcador de etnicidade.

Este processo de contato entre dois grupos ceramistas distintos pode ter ocorrido, primeiramente, numa área de interação cultural que abrangeu o vale do Araguaia e o alto Tocantins:

Estes dados sugerem que os contatos mantidos com ceramistas Uru teriam levado, em um primeiro momento e ao menos nos sítios mais próximos ao Araguaia, a profundos re-arranjos internos e, num segundo momento, a fusão dos grupos. A interação evidenciada pela cerâmica (embora não necessariamente originada por ela) parece ter constituído um fator significativo em processos de mudança cultural. (ROBRAHNGONZÁLEZ, 1996, p.104).

Em suma, a partir do século X / XI, os grupos Uru passam a ocupar mais densamente o vale do Araguaia, adentrando no território originalmente ocupado pelos grupos Aratu. Este fenômeno pode ser observado arqueologicamente na mudança do padrão de implantação dos sítios Aratu nesta bacia, passando a ocupar, também, topos de morros, numa estratégia notadamente defensiva, bem como, em algumas escolhas técnicas feitas por ceramistas aratus de elementos característicos da cerâmica uru, mostrando interação e contemporaneidade entre estes grupos. Posteriormente, o contato contínuo entre estas tradições teria levado à fusão dos grupos, emergindo uma nova unidade cultural, que vai se estender por todo o centro-sul de Goiás (ROBRAHNGONZALEZ, 1996; WUST, 1983).

A ocupação de grupos tupiguaranis na região Centro-Oeste brasileira se processou em porcentagem muito inferior, se comparada aos da tradição Aratu e Uru: 
[...] em paralelo a este complexo quadro de ocupações, temos os grupos portadores de cerâmica Tupiguarani. São os que apresentam menor quantidade de sítios dentro do Brasil Central $(7,8 \%$, em relação aos $25,8 \%$ da tradição Uru e $21,8 \%$ da Aratu), bem como características menos homogêneas, e sempre relacionadas a contatos com grupos externos. Por outro lado, ao longo de toda a ocupação Tupiguarani na região (séculos IX até ao menos o XV-XVI), seus integrantes teriam tido acesso generalizado à maioria dos demais assentamentos ceramistas da região, através da circulação de artefatos e de certos elementos tecnológicos, morfológicos e estilísticos de suas indústrias. Indicaria uma rede de relações e uma possibilidade de acesso não observada para qualquer outro grupo cultural da época. Mesmo que as demais ocupações ceramistas tenham mantido diferentes formas de contato entre si, não alcançaram uma distribuição com a amplitude da Tupiguarani. (ROBRAHN-GONZÁLEZ et. Al. 1998, p.71).

Os autores ainda ponderam que os grupos portadores de cerâmica Tupiguarani 1- apresentaram assentamentos com características bastante heterogêneas, muitas vezes classificados como sítios intra-componenciais; 2- constituíram os grupos ceramistas que por maior tempo estiveram presentes na região, pela qual estenderam uma complexa rede de contatos extra culturais e 3- esta influência poderia ser explicada por sua forte ocupação nas áreas circunjacentes, como o norte de São Paulo, que apresentam grande número de sítios relacionados a esta tradição.

A complexidade da ocupação tupiguarani no Centro-Oeste pode ser suscintamente caracterizada por uma elevada permeabilidade à adoção de elementos externos, relacionados às indústrias Uru e Aratu. Estes elementos, pondera RobrahnGonzález (1996), parecem ter-se dado a partir de fluxos de informações e/ou pessoas, enquanto os elementos Tupiguarani introduzidos na cerâmica uru e aratu estaria parcialmente relacionado a artefatos prontos, mostrando uma forma distinta de contato cultural.

A indústria cerâmica descrita por Robrahn-González (1996, p.94) para esta tradição no Centro-Oeste caracteriza-se por apresentar:

[...] porcentagens semelhantes de vasilhames diretos $(38,1 \%)$ e infletidos $(37,6 \%)$, seguidos pelos de contorno complexo $(12,8 \%)$, constituindo seus artefatos característicos. Apenas dois sítios têm peças cônicas $(10,6 \%)$ e pratos $(0,7 \%)$, indicando uma presença fortuita e possivelmente relacionada a fenômenos locais.

Os vasilhames diretos são as peças de maior peso, solidez e resistência da indústria, sugerindo um uso preferencial em atividades domesticas e 
quotidianas. São geralmente decorados com motivos plásticos. Os vasos infletidos e os de contorno complexo apresentam maiores volumes que os diretos, embora com menor peso, solidez e resistência. São preferencialmente decorados com pintura e engobo. Sem dúvida a decoração e um elemento mais expressivo neste Conjunto do que nos demais analisados, uma vez que está associado a um número bem mais elevado de artefatos $(38,7 \%)$ e tem maior variação de motivos. Isto poderia retratar uma maior diversidade funcional, tanto entre vasilhames de um mesmo contorno, como dos diferentes contornos entre si.

Nesta breve caracterização das tradições arqueológicas do Centro-Oeste brasileiro notou-se, nas pesquisas aqui descritas, o relato sobre intensos contatos mantidos entre grupos ceramistas de oeste (Uru), sudeste (Tupiguarani) e leste (Aratu), que podem ter gerado novas unidade (s) cultural (is). Estas apresentaram uma indústria cerâmica que se caracteriza por reunir atributos mistos, originalmente associados a cada uma das tradições arqueológicas em que teriam surgido.

Figura 3 - Localização dos grupos ceramistas no Brasil Central

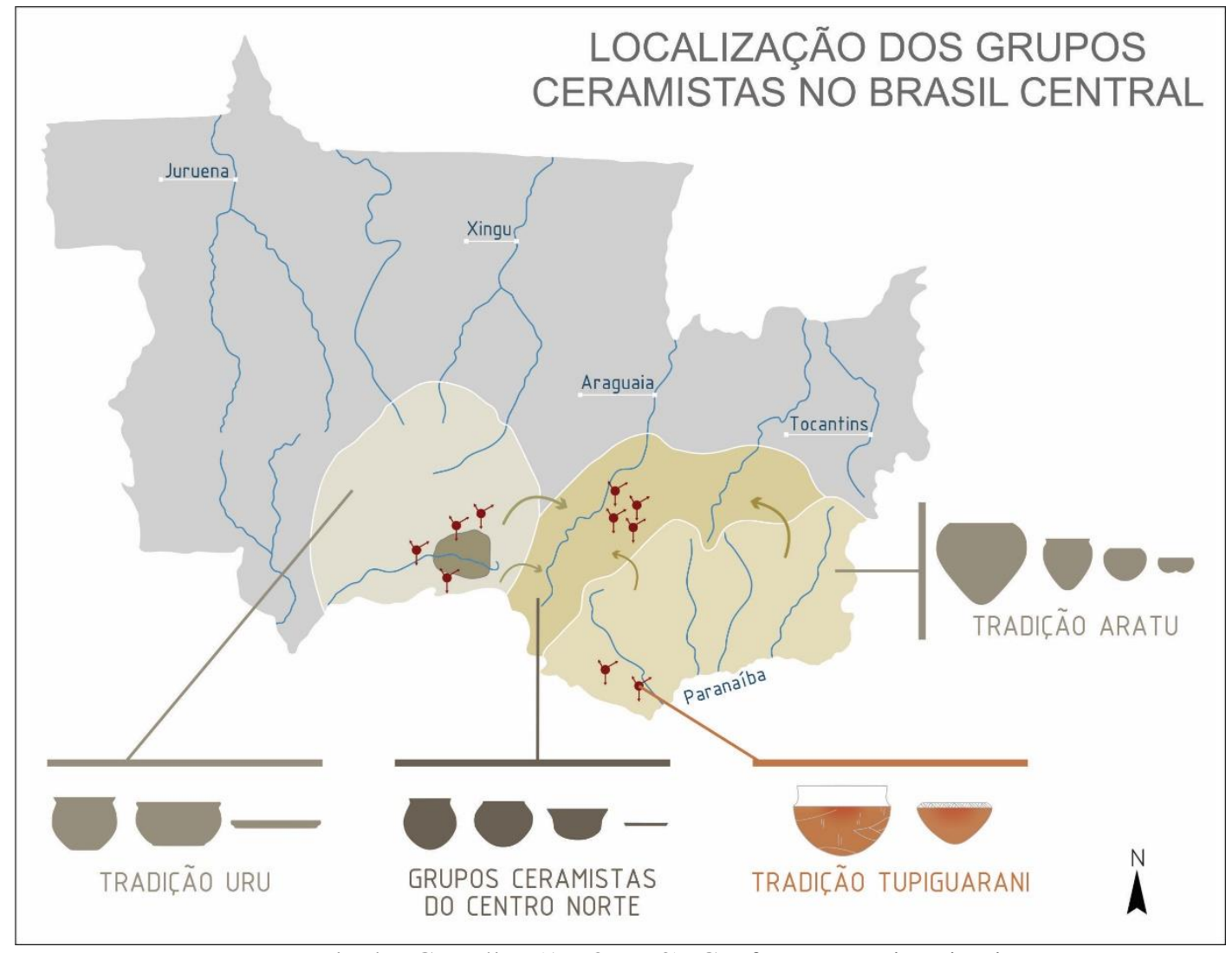

Fonte: Robrahn-González (1998, p.70). Confecção: Maria Frizarin. 


\subsubsection{O Vale do Rio Paranaíba e do Rio Grande (margem mineira)}

Uma síntese sobre a tradição sapucaí pode ser apreciada no livro Arqueologia Brasileira, de André Prous (1992). Neste trabalho, o autor afirma que esta tradição caracteriza-se por ser uma simples variedade dentro da tradição aratu. Sua área de ocorrência estende-se desde o centro de Minas Gerais até o Mato Grosso, passando pelo norte de São Paulo. No entanto, foi nos vales dos rios Grande e Verde que o Instituto de Arqueologia Brasileira encontrou o material com que foi criada esta tradição.

Sobre a instalação dos sítios, informa-nos Prous (1992, p.350) que:

[...] são instalados em regiões colinares, perto de rios, indistintamente grandes ou pequenos. Estendendo-se em amplas superfícies, com diâmetro maior de até 500 metros, ocupam as meias encostas das elevações suaves ou os baixos terraços; estes últimos, hoje frequentemente cobertos pelas aguas das represas, ficam a descoberto, às vezes, quando suas aguas baixam, mostrando imensos campos de cacos erodidos que a ausência de vegetação torna imediatamente perceptíveis.

Com base nas pesquisas realizadas por Ondemar Dias Jr. (1971;1974) no sul de Minas Gerais, sobretudo na bacia do Rio Grande, margem mineira, foi possível classificar o material cerâmico como, predominantemente, do tipo simples e 5\% do total das peças classificadas como decoradas. As variedades de decoração são: engobo vermelho, engobo branco, pintura sem engobo, banda vermelha, inciso, estriado, digitado, corrugado. Os antiplásticos identificados são: quartzo, feldspato, mica, hematita e argila. Com relação à morfologia dos vasilhames predominam as formas globulares. Para o material lítico, foram registrados polidor fixo, lascas de quartzo, lascas de calcedônia e calcário, enxó de diabásio, quebra-coco de granito, batedor de granito, lâminas de machado polido com talão picoteado e algumas com marcas de encabamento.

Para a caracterização arqueológica do vale do rio Paranaíba, margem mineira, expomos suscintamente alguns aspectos do "Projeto Quebra-Anzol”, desenvolvido desde a década de 1980 pela arqueóloga Marcia Angelina Alves (2009). Os trabalhos foram executados no alto curso da bacia deste rio, por meio de escavações intensivas, concentrados em sítios a céu aberto instalados nos afluentes e subafluentes do rio QuebraAnzol. O projeto resultou na detecção de três sítios arqueológicos classificados como agricultores ceramistas, a saber: sítio Prado, Menezes e Rodrigues Furtado. 
A cronologia destes sítios do vale do Paranaíba vai de $400 \pm 50$ anos AP (FATEC/SP) para o sítio Prado até $573 \pm 80$ anos AP (TL - FATEC/SP) para o sítio Menezes. O sítio Rodrigues Furtado encontra-se entre esta faixa cronológica, datando de $500 \pm 50$ anos AP (TL - FATEC/SP). Comenta Alves (2009) que estas datações absolutas colocam tais sítios numa situação de contemporaneidade ocupacional, todos correspondendo a uma única cultura ceramista pré-colonial caracterizada pela morfologia dos artefatos cerâmicos, líticos e emprego social dos vestígios de cultura material.

Os sítios arqueológicos em apreço situam-se no município de Perdizes, que é marcado por um quadro natural formado por uma topografia ondulada que apresenta altitudes de $900 \mathrm{~m}$ a $1100 \mathrm{~m}$. A vegetação primária, antes do desmatamento da região, era o cerradão, que corresponde ao cerrado fechado e à mata galeria junto às margens dos rios e ribeirões (ALVES, 2009).

Pondera a autora que estes sítios apresentam padrões de assentamentos e artefatos cerâmicos indicadores da tradição aratu-sapucaí, como as rodelas de fuso, que indicam tecelagem e os vasos duplos ou geminados que, segundo Alves (2009), possivelmente representavam vetores sociais de polaridades pertencentes a um universo simbólico de grupos indígenas do tronco macro-jê.

\subsection{As Áreas Circunjacentes ao CAR no estado de São Paulo}

As áreas que circunjazem o CAR são: bacia do médio-baixo Tietê, bacia do rio Mogi Guaçu e Pardo. Alguns trabalhos de referência abordam o contexto arqueológico destas áreas, tais como Afonso (2009; 2016); Afonso, Sallum e Lopes (2009); Afonso e Moraes (2007); Faccio (2017); Maranca, Da Silva e Scabello (1994), Moraes (2007); Morais (1999-2000; 2007), Robrahn-González (2000) e Scatamacchia (2006). A leitura destes trabalhos nos informa que as bacias hidrográficas supracitadas caracterizam-se por serem áreas de assentamentos pré-coloniais que apresentam fenômenos de interação socioespacial entre tradições distintas, como veremos adiante.

\subsubsection{Médio-Baixo Tietê}

Sítios arqueológicos que apresentam materiais cerâmicos relacionados à tradição tupiguarani se espalham, extensivamente, por grande parte do território brasileiro. Esta ocupação se torna singular no estado de São Paulo, por apresentar características que 
permitem diversos autores (BROCHADO, 1991; CHMYZ, 2002; SCATAMACCHIA, 2006; ROBRAH-GONZÁLEZ, 2000) afirmarem tratar-se, este estado, de um divisor territorial entre os grupos vindos do sul, denominados Guarani, e grupos vindos do norte, caracterizados pela ocupação Tupi.

Para Moraes (2007), os sítios arqueológicos localizados nos vales dos rios Itararé, Paranapanema e Paraná estariam associados à subtradição guarani, enquanto os sítios localizados no médio Tietê e Mogi-Guaçu, à subtradição tupinambá.

Se, por um lado, Chmyz (2002, p. 92) estabelece que a fronteira que divide os Tupi ao norte e os Guarani ao sul da faixa litorânea brasileira está situada na Baía de Paranaguá; por outro lado, Scatamacchia (2006, p. 124) parece concordar que esse limite para o interior do Brasil estaria situado ao norte do vale do Paranapanema, área considerada de ocupação guarani, em sua margem paranaense e paulista. Ressalta a autora que a ausência de conhecimento de uma ampla região, que se estende entre a calha do Paranapanema e a do Tietê, impede que o Paranapanema seja indicado, com segurança, como o limite norte da subtradição guarani.

Após Faccio (2017) cartografar no oeste paulista, os sítios trabalhados por ela e equipe durante anos de pesquisa, a autora afirma que os grupos guaranis:

[...] localizam-se em uma vasta área a partir do Rio Paranapanema até o Rio São José dos Dourados, passando pelos Rios Santo Anastácio, Aguapeí, Peixe e Tietê. No atual estágio das pesquisas [...] não é possível afirmar qual porção desse território possuiu uma ocupação guarani mais densa. Para isso, seria necessária a realização de pesquisas sistemáticas, o que ainda não ocorreu no Oeste Paulista como um todo. (Ibidem, 2017, p. 101).

Sabe-se que as pesquisas arqueológicas no vale do baixo Tietê iniciaram-se na década de 1970, em decorrência da construção da Usina Hidroelétrica de Ilha Solteira no Rio Paraná:

Neste período, foram prospectados oito aldeamentos pré-históricos litocerâmicos. Quatro aldeamentos foram datados pela termoluminescência de 2200 a 1040 AP. Nas coletas de superfície e nas sondagens foi obtida uma grande quantidade de material lítico e cerâmico. $\mathrm{O}$ estudo do material coletado evidenciou uma grande homogeneidade entre estes sítios, seja do ponto de vista das dimensões, que variam de 150 a $200 \mathrm{~m}$, quanto do material. Esta constatação nos levou a concluir que grupos pertencentes a uma mesma tradição cerâmica, a denominada tradição tupi-guarani, ocuparam a área 
estudada no período indicado pelas datações obtidas. (MARANCA; SILVA; SCABELLO, 1994, p. 223).

Complementam os autores que estes sítios localizados no baixo Tietê e no São José dos Dourados apresentam grande homogeneidade, no que concerne as características do material lítico e cerâmico. A datação por TL de quatro sítios arqueológicos classificados como tupiguarani, nos municípios de Pereira Barreto e Itapura, mostramnos uma ocupação contemporânea que se estende de 1040 A.P. até 1400 A.P.

Para o médio vale do Tietê, temos a descrição de trabalhos pontuais no Município de Brotas e na região de Rio Claro. Em Brotas, foi pesquisado o sítio Gramado, filiado à tradição tupiguarani, datado de $190 \pm 20$ anos A.P. por TL. Afonso (2009, p.143) afirma que este sítio "precisa ser melhor investigado porque o vale do Tietê tem sido considerado, por alguns autores, como o limite das subdivisões da tradição tupiguarani, com tupi ao norte e guarani ao sul".

No município de Rio Claro, foram detectados seis sítios arqueológicos tupiguaranis, sendo que cinco deles localizam-se no bairro Vila Paulista e um no bairro Prema. Somados a estes sítios arqueológicos foram recuperados, na cidade, três urnas fragmentadas. Estes sítios foram estudados por Altenfelder Silva, na década de 1960, e apresentaram um predomínio das decorações pintadas (MORAES, 2007).

Posteriormente, na década de 1990, os trabalhos de arqueologia realizados no trecho Paulínia/rio Paraná do Gasoduto Bolívia - Brasil (Gasbol) detectaram um sítio arqueológico, denominado Corumbataí, na cidade de Rio Claro, que foi associado à tradição tupiguarani (Ibidem, 2007).

Recentemente, Araújo (2014) realizou prospecção e resgate arqueológico do sítio Prema, durante a implantação de loteamento no município de Rio Claro. Segundo o autor, as características das peças analisadas atestam para a filiação cultural tupiguarani.

Cidades próximas a Rio Claro, como Tupã e Braúna/SP, inseridas no médio Tietê, apresentaram sítios arqueológicos filiados à tradição Itararé e foram descritos por Miller Jr. (1972).

Os sítios que apresentaram cerâmica na região de Rio Claro foram atribuídos a dois grupos distintos: 1- um grupo filiado à tradição tupiguarani, apresentando cerâmica com decoração pintada/plástica com antiplástico de caco moído (ALTENFELDER SILVA, 1967; DE BLASIS, 1998; ARAÚJO, 2014) e 2- outros sítios filiados à tradição 
Itararé, apresentando cerâmica pouco espessa, escura, com antiplástico mineral (MILLER JR, 1972).

Sobre esta última tradição cerâmica, é possível afirmar que os sítios presentes na região de Rio Claro estariam entre os mais setentrionais já encontrados para o estado de São Paulo, "sugerindo uma continuidade espacial entre os sítios tradicionalmente conhecidos no sul do Brasil e a região central do país” (ARAÚJO, 2001, p.135).

\subsubsection{Bacia do Rio Mogi-Guaçu e Pardo}

Neste subitem, foram apresentadas algumas das pesquisas que, ano a ano, procuram estabelecer um quadro mais completo da ocupação ceramista no estado de São Paulo, em sua região nordeste, delimitado pelas bacias dos rios Pardo e Mogi-Guaçu, ambos afluentes do Rio Grande.

Para a bacia do Rio Pardo ${ }^{35}$, foram localizados o sítio Tamanduazinho, município de São Simão, o sítio Água Branca, município de Casa Branca e o sítio Lagoa Preta I e II, munícipio de Serra Azul. Trata-se de quatro sítios arqueológicos que apresentam características de ocupação complexa, sobre as quais discorremos sucintamente (AFONSO, 2009).

O sítio Tamanduazinho foi datado por termoluminescência em $990 \pm 70$ anos antes do presente e, segundo Afonso (1987), apresentou cerâmica diferente da tradição tupiguarani. Estudos posteriores, sobretudo no sítio Água Branca, mostraram que a ocupação ceramista pré-colonial na bacia do rio Pardo estava associada à ocupação Jê, permitindo, segundo Afonso (2016, p.36), uma maior "reflexão sobre influências dos grupos do Brasil Central no território paulista, além de questões sobre deslocamentos geográficos e interação cultural”.

A constatação acima mencionada pela autora baseia-se nas características tecnomorfológicas da cerâmica evidenciada no sítio Água Branca, bem como da morfologia deste assentamento:

[...] sua cerâmica possui características das chamadas Tradições AratuSapucaí (cariapé, formas duplas, apêndices, brunidura), Tupiguarani (caco moído, ombros indicando vasos de formas complexas) e Uru (cariapé, bases planas com ângulos de $90^{\circ}$ ). A planta do sítio, com a

\footnotetext{
${ }^{35}$ A bacia do Baixo Pardo foi considerada como parte de nossa região de estudo e será apresentada posteriormente.
} 
indicação das áreas de maior concentração de cerâmica, revelou uma estrutura elíptica de 200 metros por 140 metros, tendo sido coletadas quase 1500 peças com estação total (Afonso e Moraes 2005/2006). As características da cerâmica, a datação recente $(205 \pm 20$ anos BP por termoluminescência para um fragmento cerâmico), a morfologia aproximadamente circular da aldeia e os dados levantados pela pesquisa etnohistórica indicam que o grupo que ocupou o sítio Água Branca está associado à ocupação Jê da região. (IBIDEM, 2016, p.36).

O sítio Lagoa Preta I e II, localizado próximo ao sítio Água Branca, apresentou cariapé como tempero de sua cerâmica, bases planas, ausência de decoração e uma datação contemporânea ao sítio Água Branca (280 anos AP), vindo a reforçar a hipótese da bacia do Rio Pardo ter sido ocupada por uma mesma tradição arqueológica, durante os séculos que precederam/procederam a colonização ocidental (AFONSO; MORAES, 2007).

As pesquisas arqueológicas na região do alto-médio rio Mogi-Guaçu iniciaramse nos anos de 1979-80 e foram coordenadas por Luciana Pallestrini. Conta-nos Morais (1995) que ao construir sua casa, o Sr. José Franco de Godoy deparou-se com algumas vasilhas de cerâmica indígena. Após os trabalhos de arqueologia nesta área, foram “evidenciadas estruturas habitacionais, funerárias e de combustão. Todas foram mapeadas, constituindo-se o plano parcial de uma aldeia pré-histórica, cujas estruturas de combustão (carvões de antigas fogueiras) foram datadas em 1.550 anos antes do presente pelo método do Carbono 14" (MORAIS, 1995, p. 79). Esta área de deposição arqueológica apresentou uma extensão de $45.000 \mathrm{~m}^{2}$ e foi denominada como sítio "Franco de Godoy".

No ano de 1992 houve uma segunda etapa de escavação para este sítio, coordenada por José Luiz de Morais, quando se ampliou o levantamento arqueológico, evidenciando outras concentrações de fragmentos cerâmicos, nova estrutura habitacional e o mapeamento das posições originais de urnas funerárias anteriormente recuperadas pelo Sr. Franco de Godoy.

A cerâmica coletada neste contexto apontou para técnicas decorativas, plástica e pintada, constatando-se o predomínio do tratamento de superfície lisa, seguido pela decoração plástica e posteriormente os pintados. Nas cerâmicas pintadas, notou-se a presença de engobo branco (predominante) e engobo vermelho com pintura vermelha, preta e branca (Ibidem, 1995). 
Vale destacar que no âmbito desta pesquisa foram identificados mais dois sítios na área arqueológica da Cachoeira de Cima, município de Mogi-Guaçu, sendo eles: o sítio Barragem e o sítio Franco de Campos. O primeiro teve sua extensão avaliada em $35.000 \mathrm{~m}^{2}$ e o segundo, ainda não mapeado na sua totalidade, apresentou uma distribuição máxima de seus vestígios em superfície ao redor de $15.000 \mathrm{~m}^{2}$. O sítio Franco de Campos situa-se em frente ao sítio Franco de Godoy, sendo separados pelo rio, e apresentando situação topomorfológica diferente.

Enquanto a aldeia FGD se implantou no flanco suave de uma colina (com seus remanescentes soterrados por coluvios) a outra, FCP, assentou-se praticamente junto ao Moji-Guacu, em um amplo terraço, hoje artificialmente transformado em "ilha", pelo canal da usina velha. (Ibidem, 1995, p. 89).

Assim, o sítio Franco de Campos situa-se entre as cotas 588 e 594 m, sendo inferior ao Franco de Godoy, situado na margem direita do rio, entre as cotas 596 e 610. Ressalta-se, ainda, que nas campanhas arqueológicas foram detectadas duas estruturas habitacionais para o primeiro sítio.

Quanto ao sítio Barragem, as pesquisas detectaram evidências arqueológicas que estavam parcialmente comprometidas pelos movimentos de terra e outros fatores pósdeposicionais. No entanto, parte do sítio apresentou evidências de cinco estruturas habitacionais "representadas por maior densidade de fragmentos de cerâmica associados a solos antropogênicos" (Ibidem, 1994, p.91).

Pondera o autor, ao final de seu artigo, que o "povoamento indígena de produtores de cerâmica da tradição tupiguarani foi denso e antigo no vale do Moji-Guaçu" (Ibidem, 1994, p. 97) salientando que a datação de 1.500 anos antes do presente, para o sítio Franco de Godoy, coloca esta ocupação como uma das mais antigas para o estado de São Paulo.

Outra área de grande interesse arqueológico no vale do rio Mogi-Guaçu é o que foi denominado por Moraes (2007) como "Complexo Cachoeira de Emas", localizado no munícipio de Pirassununga.

Comenta a autora que a análise da Coleção Manuel Pereira de Godoy coletada em Cachoeira de Emas, 
[...] aponta para uma densa ocupação dessa área por grupos associados à tradição Tupiguarani e a localização dos vestígios nas proximidades de uma área de uma cachoeira mostra o mesmo padrão de estabelecimento verificado na área de Cachoeira de Cima, município de Mogi Guaçu. (Ibidem, 2007, p. 90).

Moraes (2007) comenta que os sítios Cachoeira de Emas 1 e 2 localizam-se na margem direita do rio Mogi-Guaçu e apresentam um quadro arqueológico interessante.

Enquanto o sítio Cachoeira de Emas 2 apresentou material associado à tradição Tupiguarani [...] o sítio Cachoeira de Emas 1 apresentou indústria cerâmica diferenciada, caracterizada por paredes de espessura refinadas, pastas com antiplástico vegetal (cariapé) [...] ausência de decorações. (Ibidem, 2007, p.91).

Para a bacia do Rio Mogi-Guaçu, informa-nos Moraes (2007) que o conjunto de sítios ceramistas estudados não estariam relacionados, nem aos sítios da subtradição guarani, nem à subtradição tupinambá, mas sim, associados ao que a autora denominou de Tupi do Interior.

Apontamos como hipótese que essa região foi ocupada por grupos Tupi do interior, cujas características nos remetem mais a subtradição tupinambá, mas não aceitamos uma relação unívoca com os grupos do litoral conhecidos historicamente, sobretudo, porque os Tupinambá ocupavam densamente a costa e não a região em apreço. A variabilidade formal evidenciada mostra que estamos lidando com ocupações diversificadas daquelas do litoral, mas que pertencem, indubitavelmente, à mesma matriz cultural Tupi. (MORAES, 2007, p. 265).

Sintetizando as informações até agora levantadas para os vales do rio Pardo e Mogi-Guaçu, ambos afluentes do rio Grande, temos o Pardo situado mais ao norte do estado e o Mogi-Guaçu mais ao sul, próximo ao divisor de águas do rio Tietê. Nesta região, houve ocupações de tradições ceramistas distintas, que provavelmente relacionaram-se entre si, numa vasta área de interação cultural.

Afonso (2009), baseada em diversas pesquisas realizadas nestas bacias, infere que sítios com cerâmicas relacionadas às tradições tupiguarani e aratu/uru, datados em período contemporâneo, apontam para o intercâmbio de informações, objetos e/ou pessoas nestes assentamentos. 
O primeiro estudo de caso referiu-se ao médio vale do rio Pardo, onde foram localizados os sítios arqueológicos Lambari II (Afonso 2005; Moraes 2007), de tradição Tupiguarani, e Água Branca (Afonso e Moraes 2005/2006), com componentes das tradições Aratu e Uru, distantes $1 \mathrm{~km}$ entre si, no município de Casa Branca. O segundo estudo foi desenvolvido na área de Cachoeira de Emas (rio Mogi-Guaçu), município de Pirassununga (Zanettini Arqueologia 2006; Moraes 2007) onde foram localizados o sítio Cachoeira de Emas 1 apresentando material com características Aratu/Uru, semelhante ao material resgatado no sítio Água Branca, e o sítio Cachoeira de Emas 2 (tradição Tupiguarani) nas imediações do sítio Cachoeira de Emas 1 (Ibidem, 2009, p.37)

Desta feita, as pesquisas arqueológicas mencionadas apontam, na bacia do rio Mogi-Guaçu, um predomínio de sítios arqueológicos filiados à tradição tupiguarani, como também o é a bacia do rio Tietê, localizada ao sul da bacia supracitada. Já para a bacia do rio Pardo, ocorre o predomínio de sítios arqueológicos filiados a grupos Jê vindos do Centro-Oeste, com as suas cerâmicas possuindo características tanto da tradição aratusapucaí, quanto da tradição uru. Até agora o que foi apurado aponta um domínio tupiguarani nas bacias do rio Tietê/Mogi-Guaçu, apresentando cronologia mais antiga e, também, contemporânea às tradições associadas a grupos Jê que dominavam as bacias do Rio Grande/Pardo.

Figura 4 - Distribuição das tradições ceramistas do estado de São Paulo

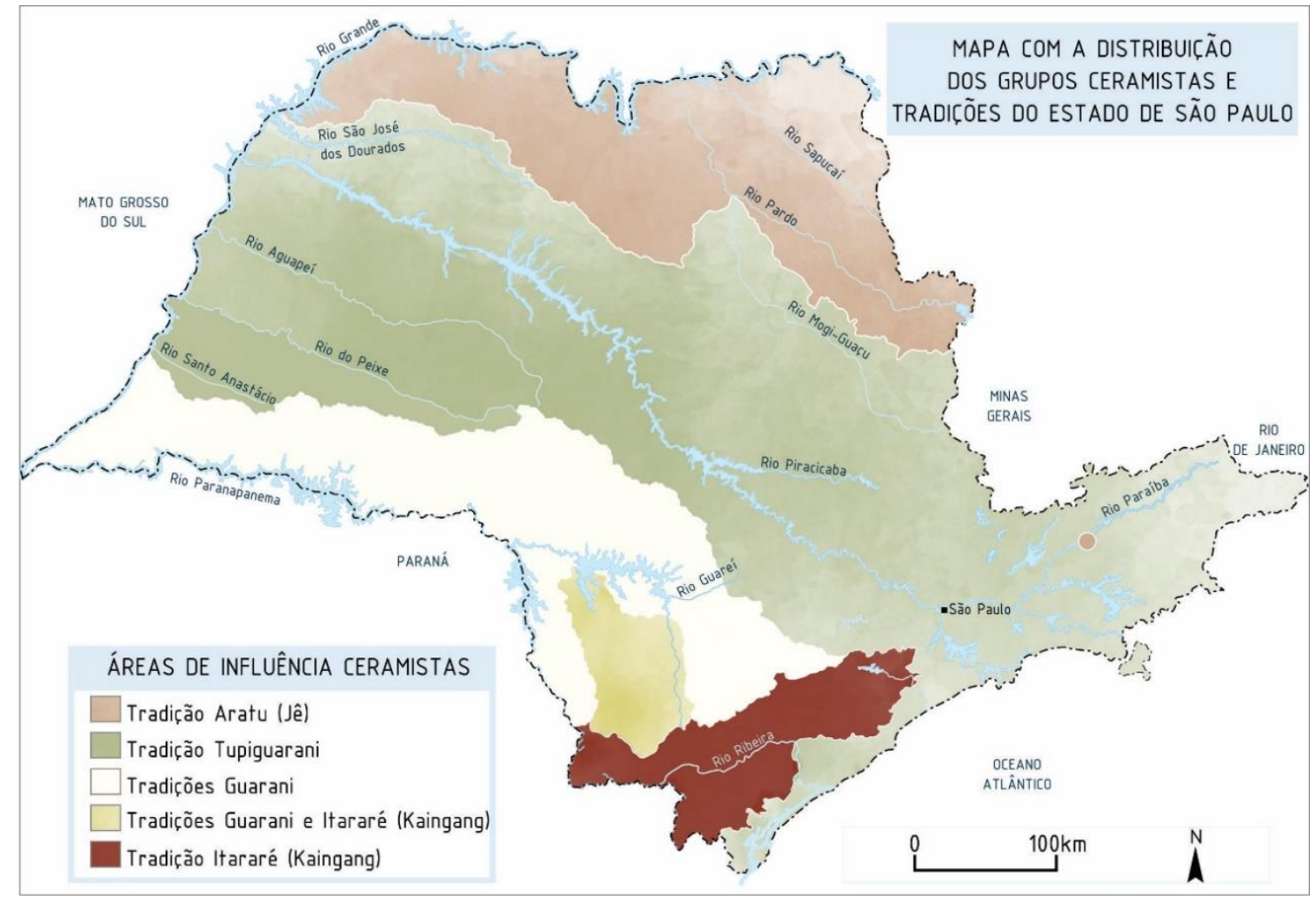

Fonte: Afonso (2010, p.12) adaptado de Morais (2005). Confecção: Maria Frizarin. 


\subsection{Contexto Arqueológico Regional (CAR)}

Como já mencionado, o contexto arqueológico ceramista pré-colonial mostra-se intrigante para nossa região de pesquisa. Isso porque a descrição dos sítios localizados nas regiões circunjacentes mostrou uma complexidade de ocupação e interação entre diversas tradições arqueológicas. Estes grupos que produziram cerâmica diferenciada deslocaram-se de diversos pontos do país e, consequentemente, apresentaram contextos culturais e ambientais diferenciados. Ao se instalarem nas bacias hidrográficas que serão aqui analisadas, ocuparam diferentes tipos de relevo, apresentaram alterações tecnológicas nas suas formas tradicionais de produzir a cerâmica e implementaram, em alguns casos, intercâmbios culturais materializados pela troca de artigos cerâmicos.

O objetivo deste subitem é ordenar as informações já obtidas para os sítios arqueológicos regionais dentro de uma escala temporal e espacial ${ }^{36}$. O material cartográfico confeccionado articula estas informações, produzindo ao final uma análise multiescalar.

O Mapa 1 mostra o conjunto de 31 sítios arqueológicos levantados no CAR e suas inserções nas bacias hidrográficas.

O Mapa 2 mostra a cota altimétrica destes sítios

\footnotetext{
${ }^{36}$ No Anexo 1 pode-se consultar as características arqueológicas, geoambientais e cronológicas dos 31 sítios analisados neste subitem.
} 
Figura 5 - Localização dos sítios arqueológicos nas bacias hidrográficas do CAR.

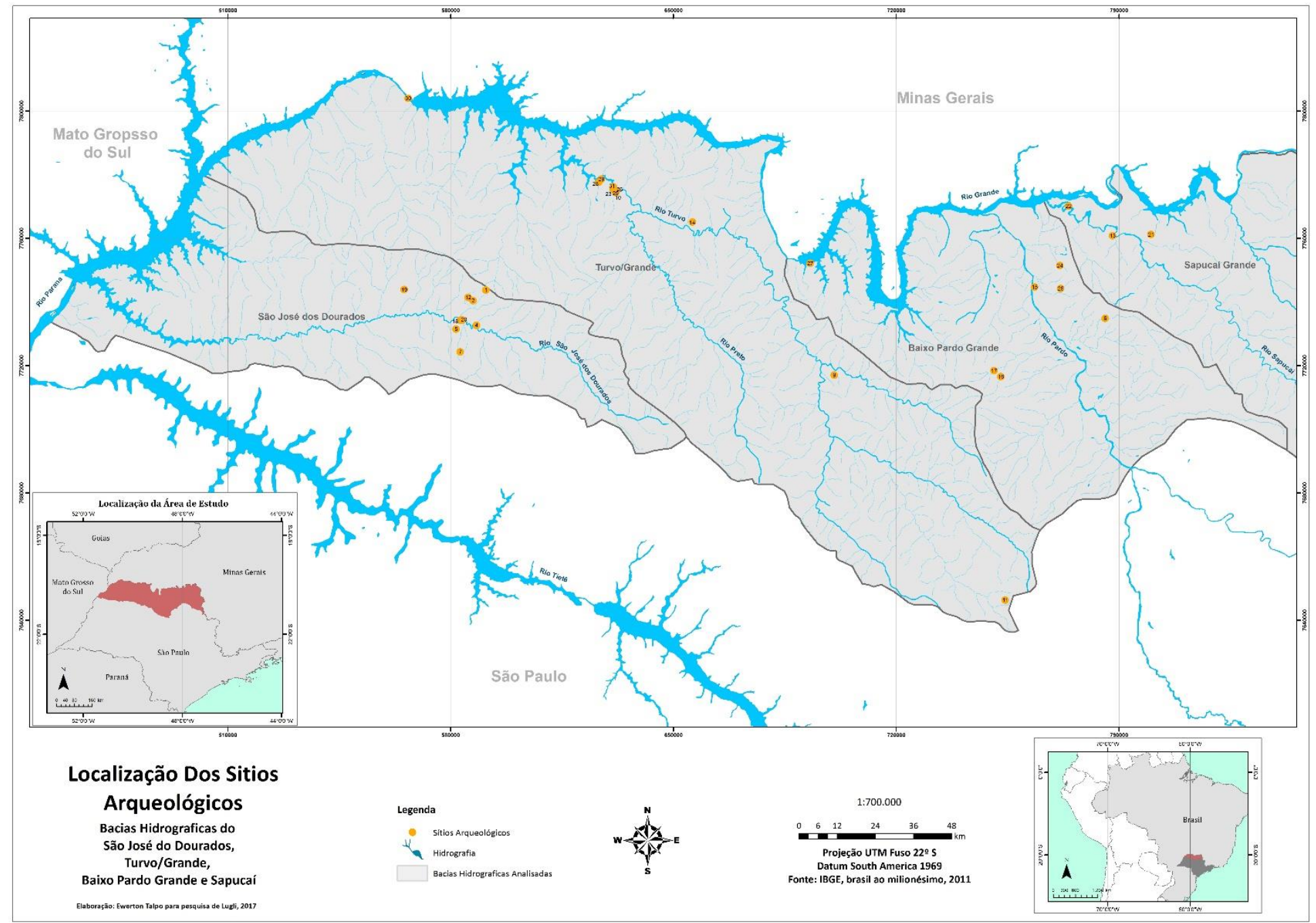

Fonte: IBGE (2011). Elaboração: Ewerton Talpo e David Pereira. 
Figura 6 - Hipsometria dos sítios arqueológicos localizados no CAR

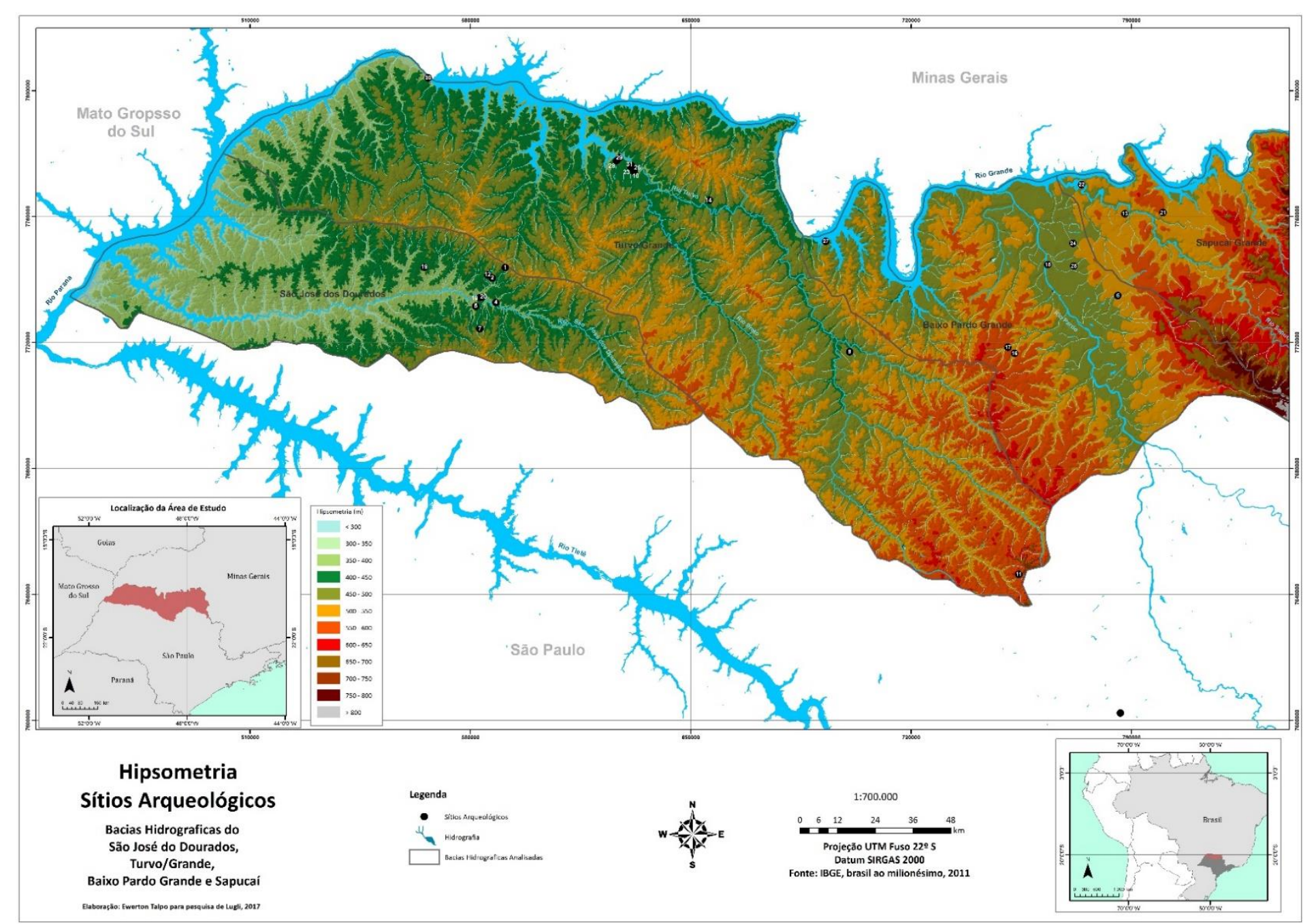

Fonte: IBGE (2011). Elaboração: Ewerton Talpo e David Pereira 
Todos os sítios aqui mencionados foram datados, por meio de diferentes técnicas como a termoluminescência e o radiocarbono, sendo divididos em cenários temporais arbitrários:

1- O primeiro cenário temporal abrange o período inicial de ocupação de grupos ceramistas na região e se deu entre os anos de 1524 A.P. até 701 A.P.

2- O segundo cenário abrangeu uma faixa cronológica de 700 A.P. até 496 A.P.

3- O terceiro cenário cobre uma faixa cronológica de 495 A.P. até 361 A.P,

4- E o quarto e último cenário abarca uma faixa cronológica de 360 A.P. até 175 A.P. Neste último cenário de ocupação, ocorreu a territorialização colonial luso-brasileira sobre as bacias hidrográficas mencionadas, marcando profundamente a ocupação indígena nesta região.

O primeiro cenário envolve quatro sítios arqueológicos, a saber: o sítio Água Limpa, classificado como o sítio mais antigo para a região, datando de $375 \pm 40$ A.P. a $1524 \pm 212$ A.P. (ALVES, 2004), o sítio Água Vermelha, datando de $700 \pm 70$ A.P. a $1010 \pm 50$ A.P (ROBRAHN-GONZALEZ, 1998), o sítio Turvo IV, datando de $740 \pm 95$ A.P. e o sítio Menino Jesus, datando de $715 \pm 55$ A.P a $600 \pm 70$ A.P $\left(\right.$ FACCIO, 2015) ${ }^{37}$

O sítio arqueológico Água Limpa localiza-se na cidade de Monte Alto/SP e está instalado na bacia do rio Turvo-Grande ${ }^{38}$. A cidade de Monte Alto está situada numa cota altimétrica média de $735 \mathrm{~m}$, na vertente da Serra do Jaboticabal, apresentando características geomorfológicas que possibilitam o encontro de redes hidrográficas importantes, sendo área de confluência tanto de córregos das bacias do Rio Tietê quanto do Rio Grande (ALVES, 2009; FERNANDES, 2001).

Alves (2009) informa-nos que a vegetação primária do município de Monte Alto era a do cerrado. Com o advento da colonização ocidental destas terras e a prática agrícola que a ela é associada, a paisagem atual apresenta uma cobertura vegetal secundária, com características do domínio da floresta estacional semidecidual. No entanto, a Serra do Jaboticabal ainda preserva remanescentes da vegetação primária do cerrado.

Apesar de o sítio não ter sido classificado por Alves (2009) em nenhuma tradição arqueológica, a autora afirma em sua tese de livre-docência que tanto os sítios estudados por ela no vale do Paranaíba, quanto o sítio Água Limpa, apresentam “artefatos-fósseis

\footnotetext{
${ }^{37}$ O sítio Menino Jesus foi objeto desta pesquisa e será detalhado no Capítulo 3. No Anexo 2 encontra-se o Laudo de datação por TL e LOE de alguns fragmentos de cerâmica deste sítio.

${ }^{38}$ É dentro da municipalidade de Monte Alto que se encontra a cabeceira de nascente do Rio Turvo.
} 
cerâmicos da tradição aratu-sapucaí” (Ibidem, 2009, p. 4-5). Esta informação mostra que o sítio em apreço possui algumas características em sua cerâmica que podem ser associadas aos grupos do Centro-Oeste.

O sítio Água Limpa está instalado num interflúvio entre os córregos Água Limpa e Santa Luzia e contornado, parcialmente, pela Serra de Jaboticabal. O sítio é extenso e abrange uma área aproximada de $12000 \mathrm{~m}^{2}$, dividida em três zonas de escavação:

- Zona 1 = $1200 \mathrm{~m}^{2}$ - pesquisada em 1993/94;

- Zona $2=5865 \mathrm{~m}^{2}$ - pesquisada desde 1994, foram desenvolvidas cinco campanhas de escavação (1995/96/2000 e 2006) e continua em processo de pesquisa;

- Zona $3=5000 \mathrm{~m}^{2}$ - ainda não escavada.

A primeira campanha de escavação iniciou-se no ano de 1993 e foi responsável pela detecção de duas manchas escuras correspondentes a antigas estruturas habitacionais, uma área de sepultamentos primários, contendo oito esqueletos, apresentando alguns acompanhamentos funerários próximos à Mancha 1 e um sepultamento secundário em urna meia esférica lisa, com tampa idêntica. Esta campanha produziu informações importantes como: "inúmeros fragmentos ósseos e conchíferos, cerâmica lisa e pintada monocromaticamente (apenas na cor vermelha), por peças líticas lascadas e por uma dimensão espacial, em torno de 10.000 m" (ALVES, 2009, p. 48).

Deste período inicial até 2009 foram desenvolvidas seis campanhas de escavação: 1993/94/95/96, 2000/06 (Ibidem, 2009).

As diversas datações absolutas conferidas para este sítio mostraram que a Zona 1 possui as datas mais antigas para a ocupação. Nela foram evidenciadas duas manchas escuras que apresentaram restos alimentares associados a vasilhames fraturados de cerâmica utilitária, lascas, raspadores, facas, fragmentos de cerâmica pintados na cor vermelha (sem engobo) e fragmentos com incisões (com e sem pintura). Na mancha 1 da Zona 1 foi evidenciada uma fogueira submetida a datação absoluta, que resultou na data mais antiga para o sítio de $1424 \pm 212$ anos A.P (Ibidem, 2009).

Para a Zona 2, as datações se apresentaram menos antigas se relacionadas a Zona 1, situando este setor no século XVII de nossa era, apresentando maior densidade demográfica e ocupando uma grande mancha de formato retangular com estrato entre 20 a $60 \mathrm{~cm}$.

A grande mancha da Zona 2 que se estende, continuamente, do metro 12,00 ao metro 53,40 do quadriculamento geral, só foi detectada em sua totalidade, com a execução do perfil estratigráfico (nos anos de 1995/96 
cujas dimensões foram: 41,40 de extensão, $2 \mathrm{~m}$ de largura na superfície e no fundo $1,70 \mathrm{~m}$ e $2,20 \mathrm{~m}$ de profundidade); o qual evidenciou a extensão e a espessura do estrato lito-cerâmico (Ibidem, 2009, p. 72).

O material arqueológico coletado durante a terceira, quarta e quinta campanha arqueológica foi analisado por Belo (2007). A quantidade de material foi dividida em três tipos: 111 peças líticas lascadas, 37 peças líticas polidas e 5.341 fragmentos de cerâmica. Quanto aos fragmentos de cerâmica, estes se apresentaram com tratamento de superfície predominantemente liso em 86,72\% dos casos, pintado em 11,43\% dos casos, e apresentando engobo em $1,85 \%$ dos casos.

O sítio Água Limpa apresenta elementos diagnósticos da tradição aratu/sapucaí como rodelas de fuso e vasos conjugados, mas, no entanto, outros elementos como alto índice de fragmentos cerâmicos pintados e sepultamentos primários não se encaixam nos padrões desta tradição, sugerindo características locais ainda pouco conhecidas.

O sítio arqueológico Água Vermelha localiza-se na cidade de Ouroeste/SP e está instalado a jusante do eixo da Usina Hidrelétrica de Água Vermelha, no baixo rio Grande, limite dos estados de São Paulo e Minas Gerais. Encontra-se em antiga planície fluvial, hoje parcialmente submersa pela represa da UHE (ROBRAHN-GONZÁLEZ et. al., 1998).

O material cartográfico produzido pela Comissão Geográphica e Geológica do Estado de S. Paulo, "Exploração do Rio Grande e de seus afluentes" (1913), mostra que a área inundada pela represa sobrepôs-se à Cachoeira da Água Vermelha. Este detalhe se mostra importante porque em Robrahn-González et. al. (1998, p.2) afirma-se que o sítio está implantado na "antiga planície fluvial da Cachoeira dos Índios”. Segundo o mesmo material cartográfico, a Cachoeira dos Índios localizava-se a leste, próximo à confluência do Rio Turvo com o Grande a, aproximadamente, $50 \mathrm{~km}$ de distância de Água Vermelha.

Os trabalhos arqueológicos no sítio Água Vermelha iniciaram-se em 1997, sendo possível, à época, detectar parte da extensão total do sítio, estipulada num eixo máximo de 60 x 40 metros. Ressaltam Robrahn-González et. al. (1998) que parte do sítio está inundada pelas águas da represa em seu setor sul, sudeste e noroeste.

Neste assentamento, foram recuperados 431 fragmentos cerâmicos, 15.142 peças líticas lascadas, oito peças líticas polidas, duas peças em ossos, uma peça em madeira e 15 sepultamentos. O material cerâmico apresentou tempero cariapé e cacomoído e antiplástico mineral, não sendo informado as suas respectivas porcentagens. $\mathrm{O}$ tratamento de superfície foi descrito como $100 \%$ liso sem decoração. 
Segundo os autores, a cerâmica do sítio em apreço apresenta:

[...] características da denominada tradição tupiguarani, tanto em termos morfológicos (vasilhas com contorno complexo) como tecnológicos (antiplástico caco moído). Ao mesmo tempo, o emprego sistemático de antiplástico cariapé remete a um contexto geograficamente distante: os grupos portadores de cerâmica uru, que se instalaram principalmente do vale do Araguaia para oeste, no atual estado do Mato Grosso. (Ibidem, 1998, p. 68)

As características apresentadas pela cerâmica, bem como a coleta de uma lâmina de machado em forma de meia lua, levaram os autores a remeterem esta ocupação a um contexto a oeste do Araguaia, considerando-a "relacionada aos grupos portadores de cerâmica Uru" (Ibidem, 1998, p. 71).

A hipótese lançada neste trabalho é de que o sítio Água Vermelha insere-se num contexto de diversificação cultural que a região central do país sofreu durante os séculos IX-X, advinda de intensos contatos mantidos entre os grupos de oeste, ou os Uru, e os de sudeste, ou os Tupiguarani. A partir deste fenômeno, emergiu uma indústria cerâmica que reuniria atributos mistos, originalmente associados a cada uma das unidades culturais.

É importante salientar que nas proximidades do sítio Água Vermelha encontraram-se mais três ocupações pré-coloniais, sendo uma delas, o sítio Água Vermelha 2, que se caracteriza como uma "extensa aldeia com abundante cerâmica, que remete indiscutivelmente à indústria aratu (contendo, inclusive, as formas duplas que lhe são marca característica) (Ibidem, 1998, p. 72).

Dois pontos cruciais marcam esta informação: 1- grandes saltos ou cachoeiras como geoindicador importante para ocupação humana pretérita e 2- a presença de tradições distintas, ocupando áreas contíguas, embora, ressaltem os autores, que a ocupação aratu para o Água Vermelha 2 seja, provavelmente ${ }^{39}$, mais antiga que a de Agua Vermelha 1.

\footnotetext{
${ }^{39}$ No trabalho em apreço não foi apresentada datação absoluta para o sítio Água Vermelha 2. No entanto, seguindo a hipótese de trabalho de Robrahn-González (1996), os autores afirmam ser "bastante difícil contarmos com uma ocupação concomitante de dois grupos ceramistas tão distintos na área, principalmente se levarmos em conta que os ocupantes de Água Vermelha teriam originado do declínio de grupos detentores de cerâmica aratu. Dentro deste contexto, poderíamos supor que o sítio Água Vermelha 2 teria sido ocupado em período anterior a Água Vermelha - sendo, portanto, mais antigo do que o século IX" (ROBRAHN-GONZÁLEZ et. Al., 1998, p. 72).
} 
O sítio arqueológico Turvo IV localiza-se na margem esquerda do córrego da Onça ${ }^{40}$, baixo curso do Rio Turvo, em baixa vertente, distante 300 metros de outra antiga ocupação humana pré-colonial, denominada sítio Turvo III. Todos os vestígios foram localizados em antigas áreas de pastagem e hoje de cultivo de monocultura, onde o uso do arado e do subsolador é frequente, promovendo a desorganização das estruturas arqueológicas dos sítios (NERY; FACCIO, 2010).

O sítio apresentou área aproximada de 150 x 100 metros, contendo neste perímetro 6.452 fragmentos cerâmicos e 311 peças líticas lascadas. Os fragmentos cerâmicos apresentaram $100 \%$ de antiplástico mineral e 99,04\% de alisamento nas duas faces.

O sítio arqueológico Menino Jesus localiza-se na cidade de Icém/SP e situa-se numa faixa de depleção da represa da UHE-Marimbondo. Os vestígios arqueológicos deste sítio estão dispersos paralelamente nas duas margens do córrego Menino Jesus, desde sua cabeceira de drenagem até a margem do Rio Grande, lado paulista (PEREIRA, 2015).

O material cartográfico produzido pela Comissão Geográphica e Geológica do Estado de S. Paulo "Exploração do Rio Grande e de seus afluentes" (1913) mostra que o sítio em tela situa-se próximo ao Salto dos Patos e à Cachoeira de Marimbondo, ambas submersas hoje pela represa da UHE-Marimbondo. A localização do sítio obedeceu a um ordenamento socioespacial estratégico, possibilitando o acesso à agua doce disponível no córrego Menino Jesus e suas diversas nascentes, acesso a jazidas de argila e a uma área extensa de cascalheira, sendo ambas aproveitadas para a confecção de utensílios, acesso a corredeiras para obtenção de peixes, acesso a uma ilha fluvial que se formava no canal do Rio Grande apresentando disponibilidade de fauna e vegetação circunscrita a este local. Possivelmente, em época de estiagem, a característica hidrográfica deste trecho do rio Grande possibilitaria a sua travessia para a outra margem, hoje estado de Minas Gerais. Nas diversas etapas de trabalho de campo foram identificados, georreferenciados e coletados 171 peças líticas lascadas, 13 peças líticas polidas e 3130 fragmentos de cerâmica. Estes materiais estavam distribuídos pelas duas margens do córrego Menino Jesus, apresentando características intrassítio que serão abordadas a posteriori.

O material cerâmico apresentou antiplástico mineral associado a hematita em $74,50 \%$ dos casos, mineral em $22,73 \%$ dos casos, mineral associado a hematita e caulinita

\footnotetext{
${ }^{40}$ Tributário da margem esquerda do Rio Turvo.
} 
em $2,46 \%$ dos casos e mineral associado ao carvão em $0,31 \%$ dos casos. $O$ tratamento de superfície se apresentou alisado em 96,89\% dos casos, com engobo em 1,46\% dos casos, com decoração plástica em $1,07 \%$ dos casos e pintura em $0,3 \%$ dos casos.

As características gerais da cerâmica analisada no sítio Menino Jesus foram associadas à tradição aratu-sapucaí. No entanto, a ocorrência de fragmentos cerâmicos apresentando parede angular e pintura sobre engobo são característicos da tradição tupiguarani. Pondera-se, também, que a rara presença de cariapé como tempero e a configuração linear do sítio remetem às características de sítios filiados à tradição uru.

Os quatro sítios que caracterizam este nível temporal mais antigo para a nossa área de estudo são marcados por algumas semelhanças e diferenças. Em primeiro lugar, tanto o sítio Água Limpa como o Água Vermelha apresentam substancial número de enterramentos dentro de seu contexto de ocupação, sendo os mesmos dispostos de maneira primária e secundária no solo.

As cerâmicas dos sítios Agua Limpa, Água Vermelha e Menino Jesus apresentam atributos mistos de tradições distintas: aratu-sapucaí e tupiguarani; uru e tupiguarani e aratu-sapucaí e tupiguarani, respectivamente. Estas ocupações provavelmente remetem a processos culturais complexos ocorridos no Centro-Oeste do país, como já mencionados. A comparação entre a morfologia dos sítios não foi possível devido ao fato de o sítio Agua Vermelha encontrar-se parcialmente inundado, não se apresentando integralmente. Por outro lado, a inserção topográfica destes sítios se apresentou distinta. Enquanto para Água Limpa, os elementos geoambientais preponderantes são as cabeceiras de nascentes dos cursos de água próximos, bem como, a Serra de Jaboticabal, para o sítio Água Vermelha e Menino Jesus destaca-se a sua inserção numa planície fluvial adjacente ao curso do Rio Grande e a Cachoeira de Água Vermelha, para o primeiro sítio, e a Cachoeira de Marimbondo, para o segundo sítio.

O segundo cenário abrange seis sítios arqueológicos, a saber: o sítio Água Limpa, o sítio Água Vermelha e o sítio Menino Jesus, mencionados no cenário temporal anterior e os sítios Turvo Vb, datando de $600 \pm 100$ A.P., Turvo I, datando de $610 \pm 80$ A.P. e o Turvo II, datando de $610 \pm 90$ A.P (FACCIO, 2014).

Os sítios arqueológicos Turvos estão localizados nos municípios de Cardoso e Pontes Gestal, na área do baixo curso do Rio Turvo, que pertence à bacia hidrográfica do Turvo/Grande. Apresentaram em suas áreas, tanto materiais cerâmicos quanto materiais líticos. As análises destes sítios foram realizadas por alunos do curso de geografia da 
FCT-UNESP, sob orientação da Profa. Dra. Neide Barrocá Faccio (NERY; FACCIO, 2010).

O sítio Turvo Vb situa-se na margem esquerda do Córrego do Anil, distante cerca de 800 metros do seu encontro com o Rio Turvo. Está instalado numa colina ampla de vertente levemente acentuada e topo aplainado e fica localizado na baixa vertente. Este sítio apresentou em sua área nove peças líticas lascadas e 32095 fragmentos de cerâmica, mostrando uma intensa atividade oleira neste local. A cerâmica caracteriza-se por apresentar $100 \%$ de antiplástico mineral e $99,53 \%$ de tratamento de superfície liso. A decoração plástica predominante é o inciso e aparece em apenas $0,43 \%$ das ocorrências (FACCIO, 2014).

O sítio Turvo I está situado na confluência do córrego do Paiol e do rio Turvo, em média vertente, distante aproximadamente 200 metros da água. A área de dispersão de materiais arqueológicos se apresentou no perímetro de 300 x 80 metros, sendo identificados e coletados 61 peças líticas lascadas e 5988 fragmentos de cerâmica. A cerâmica se caracteriza por apresentar $64 \%$ de antiplástico mineral, associado ao cacomoído e $36 \%$ de antiplástico mineral. O tratamento de superfície se apresentou em 99,89\% dos casos apenas alisados (Ibdem, 2014).

O sítio Turvo II está localizado a cerca de $1 \mathrm{~km}$ de distância do sítio Turvo I apresentando características socioespaciais e cronológicas semelhantes. A área de dispersão de materiais arqueológicos se apresentou no perímetro de 250 x 80 metros, sendo identificadas e coletadas 130 peças líticas lascadas, 16 peças líticas polidas e 2631 fragmentos de cerâmica. A cerâmica se caracteriza por apresentar 100\% de antiplástico mineral e tratamento de superfície 100\% alisados (Ibdem, 2014).

Os sítios Turvos descritos neste cenário apresentaram ocupação espacial, cronologia e característica de materiais muito semelhantes, numa área bastante circunscrita. Estas características mostram uma possível rede de interações entre locais de assentamento e atividades de um mesmo grupo cultural que habitou o baixo Rio Turvo, próximo a sua confluência com o Rio Grande, durante o século XV da Era Cristã.

O terceiro cenário abrange dezesseis sítios arqueológicos, período que caracteriza a maior quantidade e a maior dispersão de sítios arqueológicos pelas bacias hidrográficas em análise. Os sítios que compõem este cenário são: Olímpia VII (associado à tradição aratu/uru), Turvo $\mathrm{V}$ (associado à tradição aratu), Água Limpa (sem classificação), Meridiano (associado à tradição tupiguarani), Cervo (associado à tradição aratu), Bela Vista do Jacaré (associado à tradição aratu), Colina I (associado à tradição 
tupiguarani), Ribeirão das Pitangueiras (associado à tradição aratu/uru), Três Jatobás (sem classificação), Bambu (sem classificação), Dourados (tupiguarani), Capão Escuro (sem classificação), Água Azul II (associado à tradição aratu), Turvo III (associado à tradição aratu), Balsamina (associado à tradição aratu) e Santo Antônio do Lajeado (associado à tradição aratu).

Do total de dezesseis sítios arqueológicos, quatro sítios estão localizados na bacia do Rio Turvo-Grande, quatro na bacia do Rio São José dos Dourados, dois na bacia do Baixo Pardo-Grande, três na bacia do Pardo-Grande e três na bacia do Sapucaí MirimGrande. Para este cenário, nota-se que grupos culturais distintos aglomeraram-se em lados opostos, tendo a bacia do Rio Turvo-Grande e Baixo Pardo-Grande como área central de convergência cultural. A oeste do CAR, os grupos filiados à tradição tupiguarani

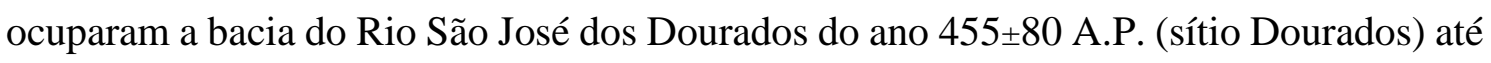
o ano 380 75 A.P. (sítio Meridiano) (FACCIO, 2011) a leste da área de estudo, os grupos filiados à tradição aratu/sapucaí ocuparam a bacia do Rio Sapucaí Mirim-Grande e PardoGrande, do ano 495 65 A.P. (Santo Antônio do Lajeado - Quem datou - é preciso citar) até o ano 395 \pm 40 A.P. (sítio Cervo) (FACCIO, 2011). Na área central de confluência cultural (Turvo-Grande e Baixo Pardo-Grande) têm-se sítios associados a mais de uma tradição, como é o caso do Olímpia VII (360 \pm 80 A.P. e $490 \pm 110$ A.P.), Colina I (420 \pm 40 A.P.) e Ribeirão das Pitangueiras (430 \pm 80 A.P.) (ZANETTINI; MORAES, 2008).

Destacamos neste cenário, o sítio Olímpia VII que está implantado em meia encosta e apresentou orientações das concentrações de material arqueológico, em paralelo a um córrego sem nome (ZANETTINI; MORAES, 2008). Esta característica assemelhase à implantação de sítios Uru do Brasil Central e ao sítio Menino Jesus, aqui já mencionados. A área de dispersão aproximada de materiais arqueológicos foi de $250 \mathrm{x}$ 100 metros, sendo identificados e coletados vinte peças líticas lascadas, dois líticos polidos e 1600 fragmentos de cerâmica.

Outro sítio que destacamos neste cenário é o Bela Vista do Jacaré (420 \pm 50 A.P., FACCIO, 2012a). Este sítio localiza-se na média vertente de uma colina aplainada, possuindo suave inclinação, onde fluem em suas imediações, o rio Pardo e o córrego do Jacaré. Este sítio apresentou área aproximada de 830 x 220 metros, sendo identificados e coletados em seu perímetro 807 peças líticas lascadas, cinco líticos polidos e 17.249 fragmentos de cerâmica, mostrando tratar-se de uma antiga aldeia indígena datada de meados do século XVII. 
O quarto cenário de ocupação retrata o último período de ocupação indígena na área de estudo e a colonização sistemática destes territórios por lusitanos e brasileiros. São apresentados neste cenário, oito sítios arqueológicos, em sua maior parte sítios filiados à tradição tupiguarani, localizados na bacia do Rio São José dos Dourados.

Destaca-se neste período, o sítio histórico Santa Filomena, localizado no município de Paulo de Faria, caracterizado como antigo cemitério abandonado, apresentando estrutura de pedra seca em formato quadrangular e cruzeiro central construído com tronco de aroeira. Este sítio está localizado em área de média vertente, próximo ao córrego do Talhadão e a $1 \mathrm{~km}$ do Rio Turvo (FACCIO, 2015). Este sítio será descrito em capítulo posterior por ter sido estudado pelo programa de arqueologia em apreço e por ser um remanescente do processo colonial da região norte do estado. 
Figura 7 - Distribuição dos sítios arqueológicos filiados a tradições arqueológicas no CAR.

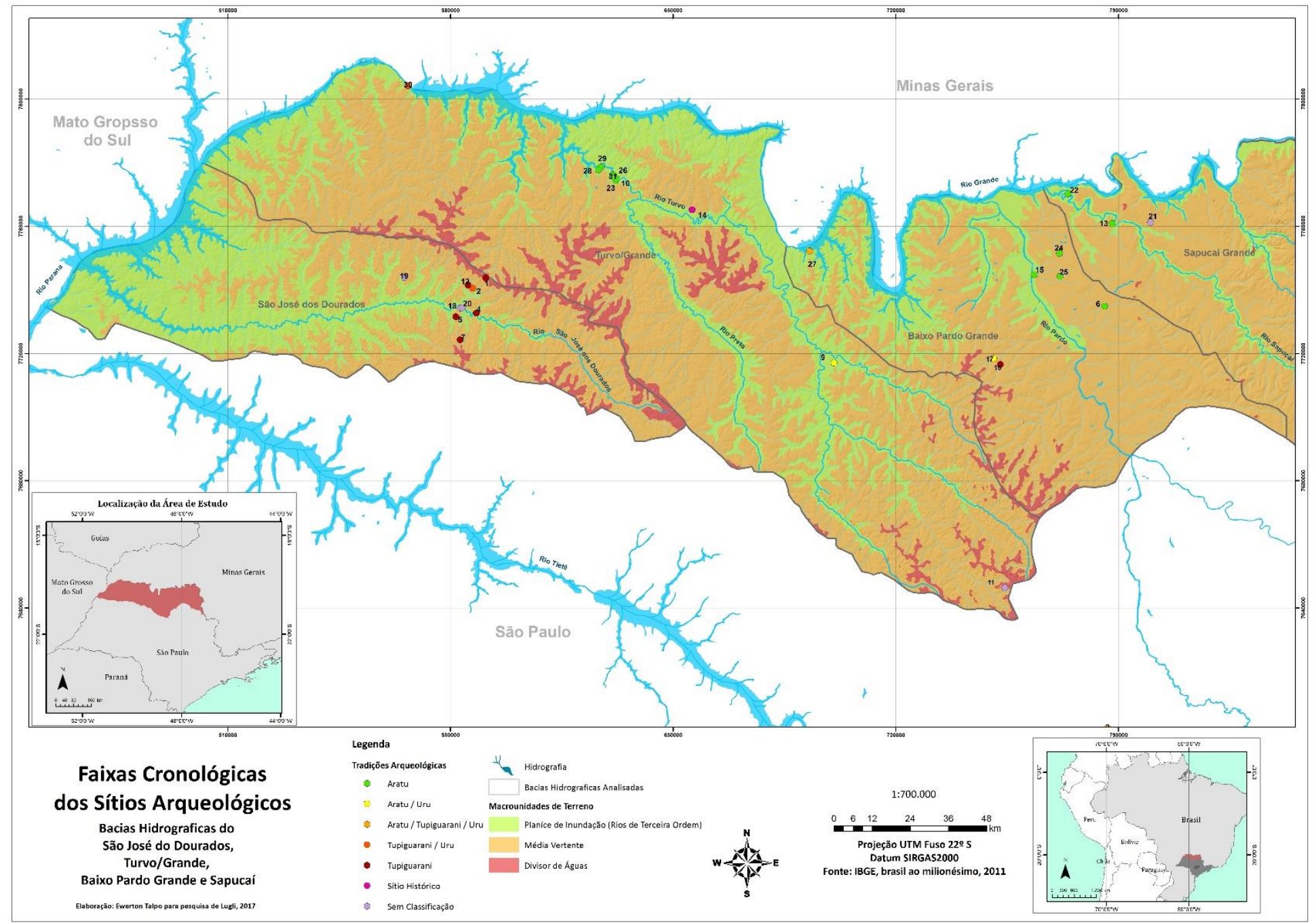

Fonte: IBGE (2011). Elaboração: Ewerton Talpo e David Pereira. 
Figura 8 - Distribuição dos sítios arqueológicos no primeiro cenário de ocupação agricultora ceramista no CAR.

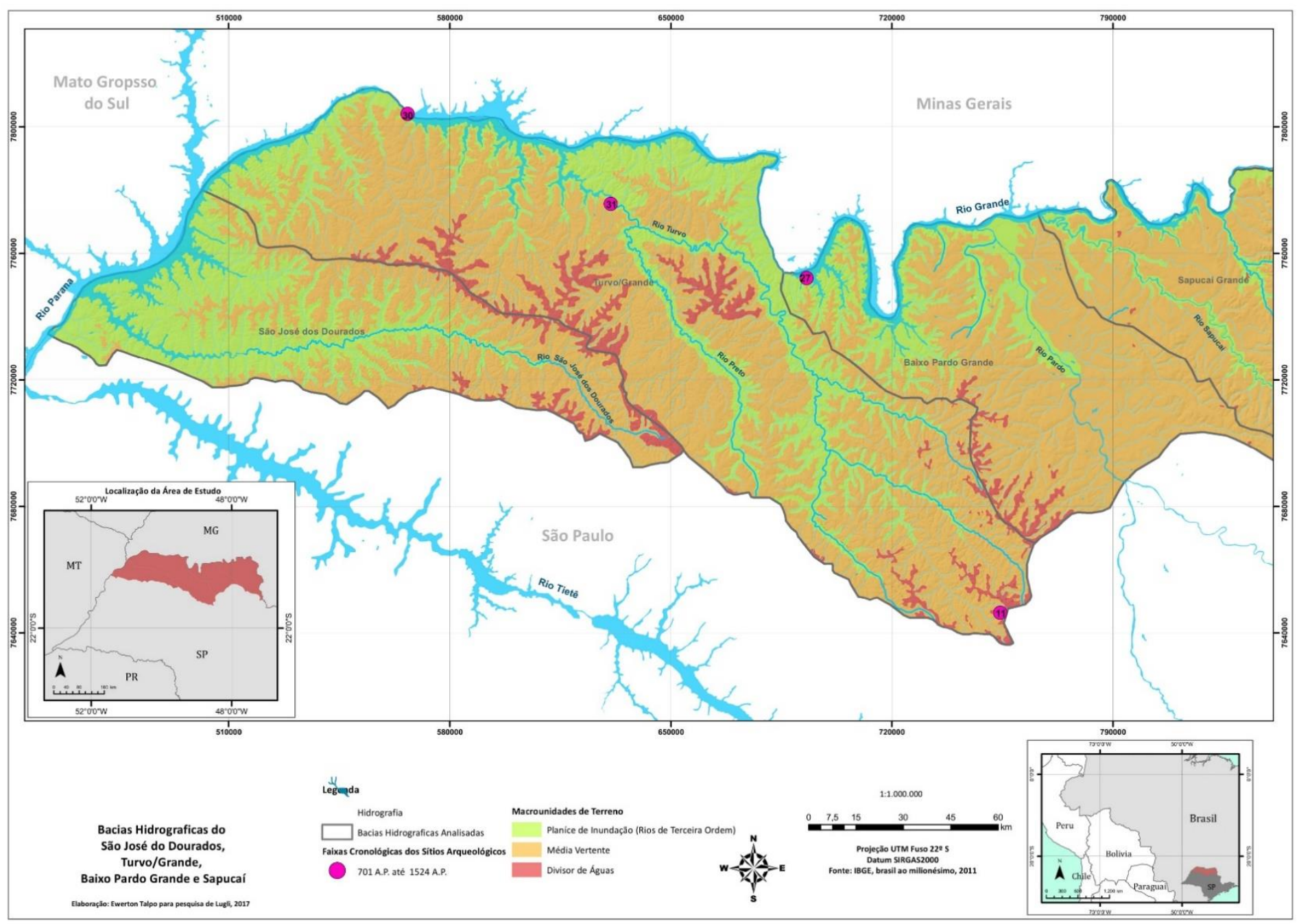

Fonte: IBGE (2011). Elaboração: Ewerton Talpo e David Pereira. 
Figura 9 - Distribuição dos sítios arqueológicos no segundo cenário de ocupação agricultora ceramista no CAR.

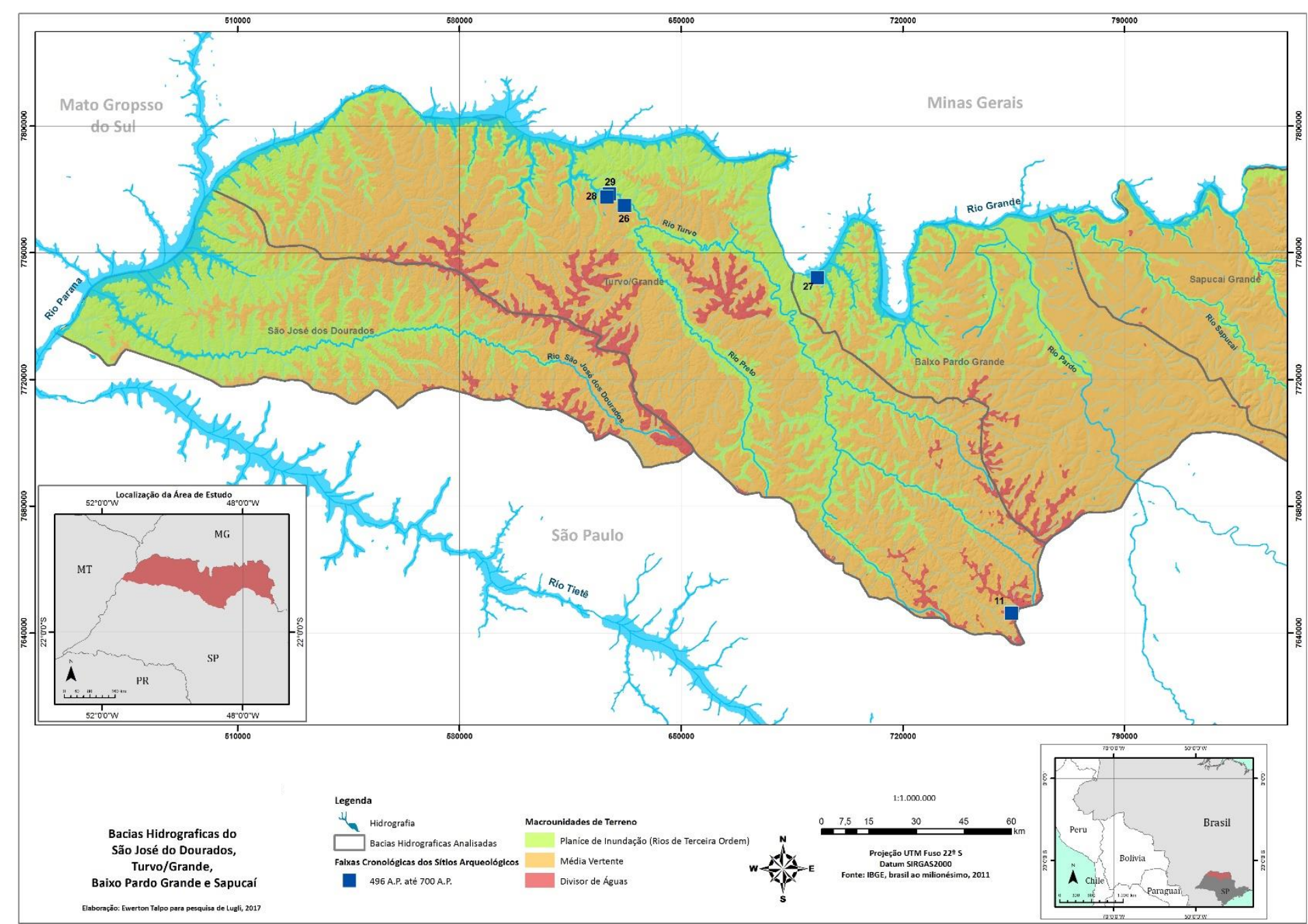

Fonte: IBGE (2011). Elaboração: Ewerton Talpo e David Pereira. 
Figura 10 - Distribuição dos sítios arqueológicos no terceiro cenário de ocupação agricultora ceramista no CAR.

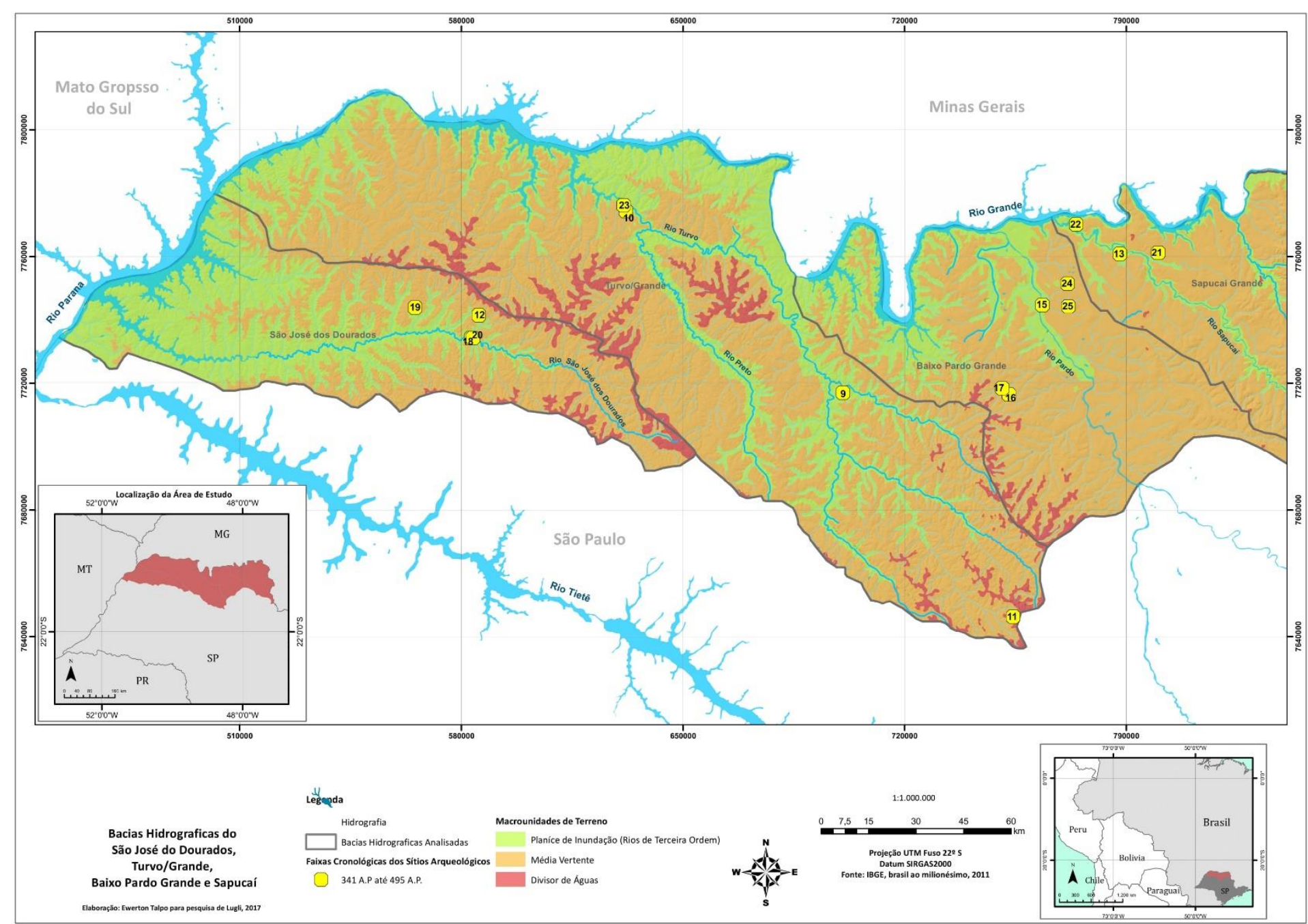

Fonte: IBGE (2011). Elaboração: Ewerton Talpo e David Pereira. 
Figura 11- Distribuição dos sítios arqueológicos no quarto cenário de ocupação no CAR.

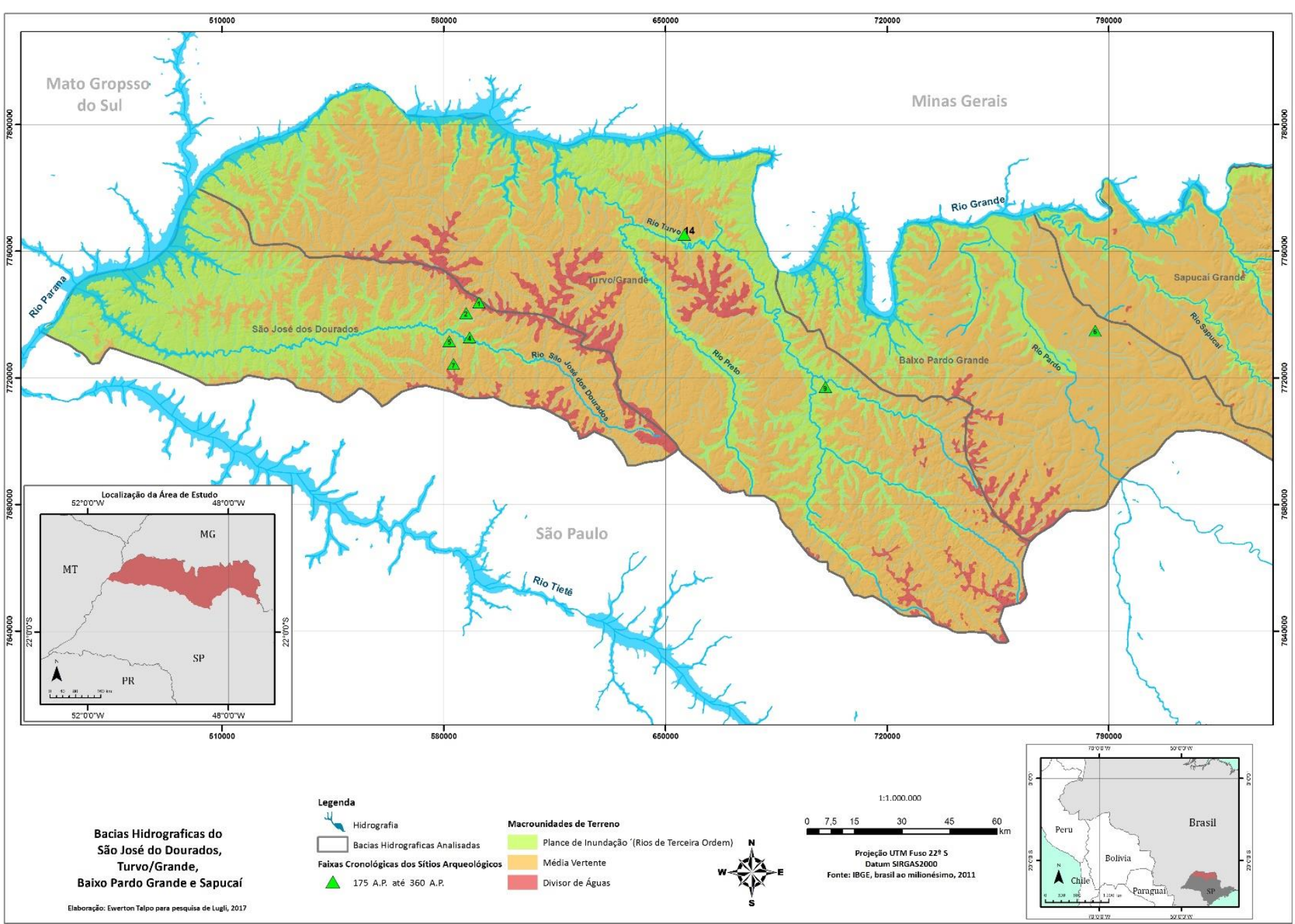

Fonte: IBGE (2011). Elaboração: Ewerton Talpo e David Pereira. Imprimir em A3 
Figura 12 - Distribuição dos sítios arqueológicos por cenários de ocupação no CAR

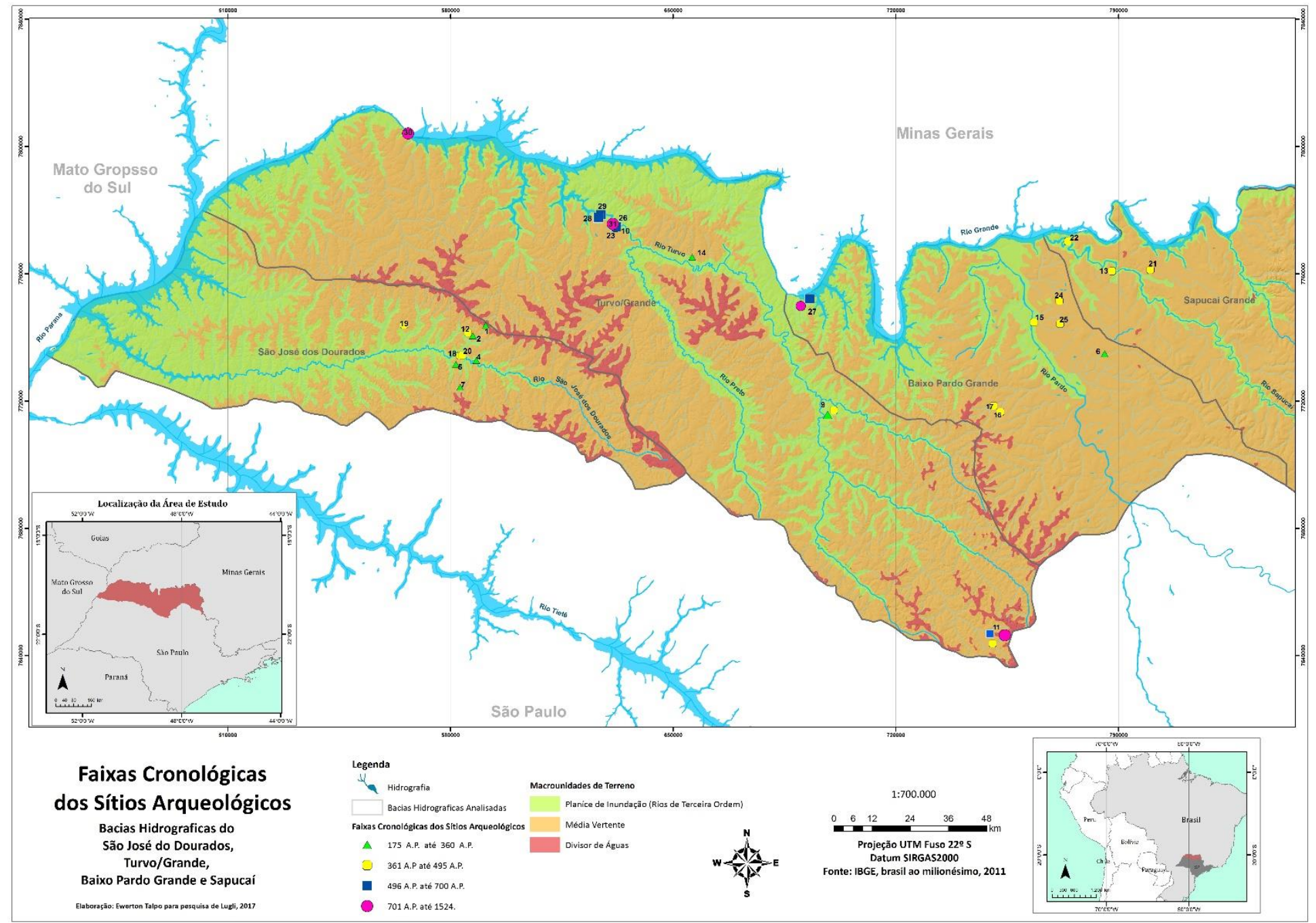

Fonte: IBGE (2011). Elaboração: Ewerton Talpo e David Pereira 


\subsection{Organização socioespacial indígena: trajetórias dos Kayapó Meridional entre os séculos XVIII e XX}

Foram produzidos dezenas de documentos a respeito dos séculos de invasão luso-brasileira ao território hoje compreendido como norte do estado de São Paulo e suas áreas circunvizinhas, como o Triângulo Mineiro, sudeste de Goiás e sudoeste de Mato Grosso do Sul. Alguns deles foram localizados/consultados por nossa pesquisa, formando um cabedal de informações sobre os elementos espaciais, sociais e culturais da ocupação indígena nesta região.

Este subitem aprofundou-se sobre as questões referentes ao território dos Kayapó Meridional ${ }^{41}$. O objetivo foi o de analisar e demonstrar suas estratégias de organização socioespacial durante o período de colonização e pós-colonização de seu território. Este período histórico iniciou-se no ano de 1722, com as primeiras expedições de Anhanguera à província de Goiás, e finalizou-se no ano de 1913, com as últimas notas históricas sobre os Kayapó Meridional no Triângulo Mineiro e norte paulista.

\subsubsection{Quem são os Kayapó Meridional?}

A família linguística Jê apresenta uma grande distribuição geográfica, exclusivamente brasileira, ocupando, sobretudo, a região central do país em áreas de campos cerrados. A família Jê subdivide-se nos seguintes grupos: Timbira, Kayapó, Akwén e Kaingang, ressaltando que as línguas dos Suyá, Kren-akarôre (Panará) e dos Tapayúna estão aparentadas mais estreitamente com o grupo Kayapó (Rodrigues, 1994; Vasconcelos, 2013).

Dentro do grupo Kayapó, existe uma distinção entre grupos do Sul e do Norte, proposta pela primeira vez por Ehrenreich, no final do século XIX. Entre os Kayapó do Norte, estão os Xikrin, Gradaú, Gavião, Apinajé, Krahô e Timbira e entre os Kayapó do Sul, incluiu-se os Panará (Giraldin, 1997).

Segundo Giraldin (1997), Vasconcelos (2013) e Mano (2010), a designação Kayapó Meridional ou Cayapó do Sul refere-se aos antepassados dos Panará. Esse grupo historicamente habitou desde o sul de Goiás (margem direita do Paranaíba e formadores

\footnotetext{
${ }^{41}$ Explicaremos a utilização do termo Kayapó Meridional em detrimento de Cayapó do Sul num posterior segmento do texto. Fazemos a ressaltava que o termo Cayapó irá aparecer no corpo do texto, mas o mesmo fará referência a citações diretas ou indiretas de outros autores.
} 
do Araguaia), sudeste do Mato Grosso (afluentes da margem direita do Paraná até o Alto Taquari e Piqueri), noroeste de São Paulo e Triângulo Mineiro.

Tanto Giraldin (1997) quanto Vasconcelos (2013) utilizam o termo Cayapó com "C" e não com "K", como é convencional, no sentido de distinguir entre os grupos "do Norte" com "K” e os grupos "do Sul” com “C”. Ressalta Giraldin (1997) que a adoção do termo Cayapó atende a grafia da época em que foram retratados.

Sublinhamos que os povos Jê, entre os quais predomina a designação genérica Kayapó ou Cayapó, não corresponde a uma etnotaxonomia social, mas aponta para uma alcunha criada pelos próprios colonizadores e grupos indígenas inimigos, frente a uma gama de dialetos e subgrupos filiados a este termo (Mano, 2010; Rasteiro, 2015).

A exemplo de Rasteiro (2015), o nome que usaremos para designar este grupo indígena será Kayapó com a letra "K”, segundo a convenção assinada em 1953, na primeira Reunião Brasileira de Antropologia. Kayapó Meridional (ou do Sul) será a denominação usada por nós, no que tange à diferenciação do grupo kayapó setentrional (ou do Norte), os quais, embora aparentados, são claramente diferentes e não podem ser considerados como derivados um do outro (Giraldin, 1997, Nimuendaju, 1952). A alcunha Caiapó ou Cayapó será usada neste texto apenas nos casos de citações diretas ou indiretas de outros autores.

\subsubsection{Qual era seu território e em que época histórica foram retratados?}

O conceito de território e seus desdobramentos socioespaciais são fundamentais para o entendimento da organização/reorganização do espaço pelos grupos kayapós meridionais, ocorrida entre o século XVIII e início do XX.

Para iniciarmos o entendimento do conceito de território, é necessário entendermos que o mesmo possui duas características que se complementam: a de ser 1funcional e 2- simbólico, pois grupos humanos exercem o "domínio do espaço tanto para realizar funções quanto para produzir significados” (HAESBAERT, 2005, p. 6776).

Território relaciona-se a poder e este poder pode ser entendido como dominação e apropriação. Dominação está vinculado ao fato concreto; aquilo que é funcional e vinculado ao valor de troca. Enquanto apropriação assume, na visão de Haesbaert (2005), um caráter mais simbólico, carregando as marcas do vivido e de seu valor de uso. Desta feita, o território vai "da dominação político-econômica mais concreta e funcional à apropriação mais subjetiva ou cultural-simbólica” (IBIDEM, 2005, p. 6775). 
O território dos Kayapó Meridional, descrito por 190 anos, sofreu uma mudança no peso da balança entre estas duas características do território: funcional/valor de troca x simbólica/valor de uso. A empresa do colonialismo e pós-colonialismo fez com que a primeira sobrepujasse a segunda, sufocando as possibilidades de uma efetiva reapropriação dos espaços, que então foram, paulatinamente, sendo dominados pelo Império Português e transformados em mercadoria, neste caso, numa área de exploração aurífera e ocupação colonial.

As delimitações territoriais historicamente, fixadas por meio das estratégias de poder e controle político do Estado, se diferem da ideia de território indígena, cuja imagem principal parece ser um tecido espacial/cultural regido por movimento e fluidez (BONNEMAISON, 2002; CAVALCANTE, 2013).

O território indígena é uma terra tradicionalmente habitada por um grupo cultural. Terra essa, muitas vezes, caracterizada com fartura de nomes êmicos, que além de conceituarem a paisagem, também idealizam um conjunto de lugares hierarquizados e conectados a uma rede de itinerários (BONNEMAISON, 2002; FERGUSON \& CHANTHAPHONH, 2006).

Neste aspecto, a territorialidade se situa na junção entre a fixação dos lugares e a mobilidade, ou seja, os itinerários. Interessante notar a compreensão do conceito de territorialidade do geógrafo cultural Bonnemaison (2002, p.107):

\footnotetext{
A territorialidade é a expressão de um comportamento vivido: ela engloba, ao mesmo tempo, a relação com o território e, a partir dela, a relação com o espaço "estrangeiro". Ela inclui aquilo que fixa o homem aos lugares que são seus e aquilo que o impele para fora do território [...] toda a análise de territorialidade se apoia sobre uma relação interna e sobre uma relação externa: a territorialidade é uma oscilação contínua entre o fixo e o móvel.
}

O autor considera ainda que é por meio da territorialidade que um grupo "exprime sua concepção de mundo, sua organização, suas hierarquias e funções sociais" (BONNEMAISON, 2002, p.124).

Para podermos operacionalizar o conceito de território e territorialidade aplicado aos grupos kayapó meridionais, partiremos da formulação de Zedeño (1997). A autora define território como um espaço delimitado por uma sociedade, onde interações entre homens e terra acontecem através do tempo. Existem, assim, três elementos materiais centrais: a terra, os recursos naturais e as construções humanas. Estes elementos 
culminam em três dimensões essenciais de um território: as interações homem e terra, a escala espacial dessas interações e os processos históricos do uso da terra.

Para Zedeño (1997) a história de vida de um território inicia-se com o estabelecimento de um grupo de pessoas em uma área particular. Três processos associados a este acontecimento podem ser delimitados: exploração, colonização e assentamento.

Por exploração, a autora entende o reconhecimento das áreas de recursos potenciais e a sua utilização limitada. Alguns desdobramentos dessas atividades são a marcação de locais específicos para uso futuro e construção de abrigos. Em suma, áreas de exploração são territórios logísticos e podem ser incorporados dentro do território préexistente, através da exploração exclusiva ou exploração de certos recursos.

Por colonização, entende-se um prolongado período de experimentação, quando um grupo avalia as capacidades de apoio de uma paisagem natural e sua manutenção. Desdobramentos podem incluir o estabelecimento de residências permanentes ou semipermanentes, campos agrícolas, áreas de caça, pesca, coleta e exploração de matérias-primas para ferramentas, construções e outras necessidades.

O último processo é o assentamento, sendo o espaço organizado de forma permanente, com sua partição para a realização de construção e produção. Rituais de longo prazo e outras instalações se desenvolvem junto à construção da aldeia. O processo de assentamento pode incluir a demarcação de uso interno e externo da terra e os limites de propriedade.

O processo de assentamento pode gerar três fenômenos espaciais: sua expansão, sua consolidação e sua físsão.

Por expansão, entende-se quando os territórios são ocupados por várias gerações ou se estão abertos a migrantes ou â assimilação de recém-chegados. Alguns desdobramentos são as mudanças dos limites, aparecimento de comunidades satélites, ajuste do espaço de vida e da utilização dos recursos associados, ajuste do loteamento de campo agrícola e construção de estradas e trilhas que abrem acesso às áreas recémassentadas.

Em consolidação, o grupo desenvolve estratégias integrativas capazes de alcançar equilíbrio entre a produção e a conservação de recursos.

Em fissão ocorre a fragmentação de uma unidade territorial em outros segmentos e podem ser geradas por uma má integração das estratégias organizacionais, conservação do ambiente, guerra civil ou invasão de outros grupos. A expansão de um território 
também pode gerar a divisão de uma unidade territorial, para que outros grupos colonizem terras adjacentes (Ibidem, 1997).

Cabe salientar que os processos envolvidos na formação de uma unidade territorial e sua história de vida não assumem uma estrutura linear, mas cíclica, onde os processos de estabelecimento e manutenção estão interligados. A fissão de um assentamento, por exemplo, pode gerar a exploração de novos territórios, que por sua vez iniciará um novo processo de colonização, assentamento, expansão, consolidação e fissão. Esse processo pode ocorrer em áreas novas, nunca antes exploradas, colonizadas ou assentadas, ou pode ocorrer em áreas que nunca foram totalmente abandonadas, como terras ancestrais, aldeias e locais rituais (Ibidem, 1997).

A perspectiva de território apontada por Zedeño (1997) faz referência, sobretudo, à organização de um conjunto de lugares que vão se estabelecendo e reestabelecendo com o tempo, devido a uma gama de fatores de ordem interna (sociocultural) e externa.

Em nosso caso, os fatores de ordem externa estão fortemente associados ao processo de conquista por colonizadores luso-brasileiros que se organizaram politicamente, apropriaram-se das terras e modificaram os territórios das comunidades locais, impondo nova territorialização (OREJAS, 1998). Caminhos terrestres que conectam as províncias da colônia foram fundados; trajetos fluviais, como as monções, estabeleceram rotas comerciais; a guerra é declarada e a supressão de grupos inimigos implantada e o aldeamento dos remanescentes indígenas torna-se política de Estado. Como disse Alfredo Bosi (1993), o papel do colonizador nesse período foi o de explorar e controlar o território recém-ocupado, bem como, brutalizar e submeter os povos naturais da terra.

É neste terreno, obviamente, que teremos que tecer a trama e o drama dos Kayapó Meridional durante quase 200 anos de colonização e exploração de seu território, bem como, suas características e estratégias socioespaciais.

A caracterização histórica do território ${ }^{42}$ kayapó meridional está fortemente associada ao processo de conquista por colonizadores luso-brasileiros. Neste aspecto, a

\footnotetext{
${ }^{42} \mathrm{O}$ conceito de território indígena se difere das delimitações territoriais fixadas por meio do poder e controle do Estado. O território indígena é uma terra tradicionalmente habitada por um grupo cultural, caracterizada com fartura de nomes êmicos, que além de conceituarem a paisagem, também idealizam um conjunto de lugares hierarquizados e conectados a uma rede de itinerários (BONNEMAISON, 2002; FERGUSON \& CHANTHAPHONH, 2006).
} 
territorialidade kayapó meridional ${ }^{43}$ é melhor compreendida nos documentos históricos, se associada ao processo de territorialização colonial ${ }^{44}$.

A territorialização colonial forçou a uma reorganização territorial kayapó. Assim, num primeiro momento, eles foram desterritorializados, mas, posteriormente, eles se reterritorializaram em outras áreas já previamente conhecidas de seu próprio território que, no entanto, apresentavam outra função para sua organização socioespacial. Ou seja, áreas que antes eram cursadas com o intuito de realizar diversas atividades de subsistência, como coleta e pesca, foram transformadas em áreas de assentamento (CAVALCANTE, 2013; HAESBAERT, 2005).

O objetivo deste item é demonstrar a história de vida ${ }^{45}$ do território dos Kayapó Meridional, acompanhando suas movimentações e a transformação/manutenção de sua organização socioespacial. Iniciaremos a análise do território/territorialidade kayapó meridional com os relatos de Antônio Pires de Campos ([1723] 1862) que, navegando pelos rios Tietê, Paraná e Paranaíba, escreve:

[...] fallando do Rio Grande ${ }^{46}$ (em que mete o Thieté e perde o seu nome) navegando por elle acima, se dá em um rio chamado Pernahiba ${ }^{47}$, e por elle cima habitam o gentio chamado Cayapó. Este gentio é de aldêas, e povoam muita terra por ser mui a gente, cada aldêa com seu cacique, que é o mesmo que governador [...] vivem de suas lavouras, e no que mais se fundam são batatas, milho, e outros legumes, mas os trajes d'estes barbaros é viverem nús. (CAMPOS, 1862, p. 437).

Este pequeno fragmento de texto é suficiente para delimitarmos parte do território kayapó, ou seja: Rio Paraná acima, até seu encontro com o Rio Paranaíba, onde hoje é a divisa dos estados de Goiás, Minas Gerais e São Paulo. O texto também faz referência às aldeias que se espalham por uma faixa de terra considerável, por haver "mui a gente", tendo a organização política gerida por um cacique, cada qual comandando sua aldeia, e, provavelmente, organizando as lavouras onde a batata e o milho parecem ser os cultígenos mais importantes.

\footnotetext{
43 Entendida como estratégias de movimentações socioespaciais dentro e fora de seu território (BONNEMAISON, 2002).

${ }^{44}$ Entendido como um processo de conquista ou organização por parte dos colonizadores, que se apropriam e modificam os territórios das comunidades locais, impondo nova territorialização (OREJAS, 1998).

${ }^{45}$ Para Zedeño (1997) o território indígena assume uma estrutura cíclica que pode ser analisada em três dimensões essenciais: interação homem-terra, escala espacial das interações e processos históricos de uso da terra.

${ }^{46}$ Nesta época o Rio Paraná era chamado de Rio Grande.

${ }^{47}$ Pela descrição do autor refere-se ao Rio Paranaíba.
} 
O território kayapó descrito por Campos ([1723]1862, p.438) se estende, no sentido sul, até onde hoje é o Rio Pardo (MS) e, na direção oeste, até onde hoje é o Rio Taquari (MS). Informa o autor que este vasto território não era, necessariamente, todo ocupado por aldeias kayapós, mas formavam vastas áreas de mobilidade territorial, onde este grupo utilizava os recursos e faziam guerra com outros grupos indígenas e colonizadores luso-brasileiros.

A territorialidade kayapó meridional, bem como, o usufruto da terra e a prática de ataque aos colonizadores dentro de seu território pôde, também, ser apreciada em outra fonte histórica. No ofício de Gomes Jardim ${ }^{48}$, endereçado ao Governo Imperial no ano de $1869^{49}$, comenta o autor sobre a aldeia do Piquiri ${ }^{50}$, localizada à margem do rio homônimo, no estado de Mato Grosso do Sul. Jardim (1869, p. 551) escreve: “os homens entranham-se no sertão durante parte da boa estação do anno á cata de mel e de caça, e presume-se que n'estas excursões elles chegam ás vezes até a estrada de Goyaz, e tem ahi commettido parte dos malefícios".

Se considerarmos que estes homens habitavam a Aldeia do Piquiri, localizada ao norte do Mato Grosso do Sul, e que suas excursões chegariam à estrada de Goiás, a mobilidade sazonal deste grupo era muito extensa e, provavelmente, pontilhada de aldeias e acampamentos, onde faziam paragens.

No ano de 1817, Manuel Aires de Casal, pesquisador português, define o território dos Kayapó Meridional como Caiapônia. Na visão do autor, a Caiapônia, obviamente habitada pela nação Kaiapó Meridional, que a ocupa desde tempos imemoriais, se estendia ao norte até o distrito de Goiás, ao oeste até a Bororonia, da qual é separada pelo Rio Araguaia, e a sudeste os rios Paraná, Paranaíba e Anicuns, que separam, o primeiro da Província de São Paulo e os demais do distrito do Rio das Velhas.

Conforme os anos de colonização do centro-oeste brasileiro transcorriam, novos dados sobre os Kayapó Meridional apareciam. No ano de 1861, Machado de Oliveira (1861, p. 496) escreve que todo o "território dominado por esses índios no seu descobrimento está como encaixilhado pelas Serras Dourada, Santa Martha, e Sellada, e estende-se até à margem septentrional do Paranahiba, um dos mais volumosos braços do Paranã e seu confluente do lado direito". Salienta Machado de Oliveira que nesta época

\footnotetext{
${ }^{48}$ Presidente da Província de Mato Grosso.

${ }^{49}$ Portanto, 146 anos depois dos relatos de Campos.

${ }^{50}$ Apesar de o ofício ter sido dirigido ao Governo Imperial no ano de 1869, o comentário a seguir relata atividades dos Kayapó nessa aldeia, por volta da década de 1830, como se faz entender no documento.
} 
os Kayapó sofriam intenso ataque dos colonos "mamelucos", que nas terras destes indígenas andavam à procura de ouro. Ao que parece, uma estratégia tomada pelos Kayapó foi a de fazerem "parada", a distância destas frentes de exploração aurífera, onde pudessem tomar situação defensável. $\mathrm{O}$ autor informa que estes locais escolhidos foram próximos ao Rio Paraná e Serra de Santa Marta.

Ressaltamos que a região setentrional do Rio Paraná foi um ponto estratégico para os Kayapó, tanto no que se refere à sua economia pesqueira, quanto para fugir das frentes de colonização aurífera.

Campos ([1723] 1862) menciona que um aglomerado de aldeias kayapós localizava-se acima do Rio Paranaíba e que eles realizavam excursões para o Rio Paraná e afluentes (Rios Sucuriú e Verde), enfatizando que nesta área não havia aldeias. Duas questões podem ser levantadas neste ponto: 1- Campos não sabia da existência de aldeias nesta região? 2- Neste período, esta área fazia parte do território kayapó, mas não era utilizada como habitação?

Desta feita, se, em 1723, nenhuma aldeia foi mencionada por Campos ([1723] 1862) no Paraná e afluentes, em anos posteriores, outros viajantes as mencionaram. Este processo de povoamento nesta região, provavelmente, se deu pela expulsão e/ou aldeamento dos Kayapó no caminho de Goiás, sobretudo na região de Vila Boa de Goiás, onde se concentrava a exploração aurífera. Diante da pressão colonizadora, parte dos grupos kayapós assumiram a estratégia de migrar para o Rio Paraná e afluentes, estabelecendo aldeias e formando uma organização socioespacial bem definida.

Alguns relatos históricos ajudam-nos a entender este processo de territorialidade/territorialização kayapó. No ano de 1726, uma descrição do então governador de São Paulo, Rodrigo César de Meneses, transcrita por Afonso Taunay ([1961] 2012), comenta que a tropa seguindo viagem Rio Paraná abaixo foi dormir na barra do Rio Apeú, numa dilatada "praia da parte esquerda, porque da direita anda o gentio, que é de certo o pior que tem estes sertões" (TAUNAY, 2012, p.223).

$\mathrm{O}$ relato em apreço foi realizado numa época contemporânea à de Campos ([1723] 1862). Mesmo não mencionando qual seja o "gentio" desta região, pressupomos que sejam os Kayapó ${ }^{51}$. O fato de o autor dizer "anda", mostra que os mesmos não estavam estabelecidos ali, mas, provavelmente, essa região era alvo de suas excursões, já naquela época temidas pelos aventureiros e colonizadores.

\footnotetext{
${ }^{51}$ O local citado abarca a extensa área descrita por Campos ([1723] 1862) como território Kayapó.
} 
Oitenta e quatro anos depois da viagem de Meneses pela confluência do Rio Tietê - Paraná abaixo, João Ferreira de Oliveira Bueno ${ }^{52}$ realiza o mesmo trajeto fluvial, descrevendo os acontecimentos desta viagem. O primeiro contato com os Kayapó se deu ao retornarem à barra do Rio Tietê, próximo a uma ilha na confluência com o Paraná, com três indígenas que pescavam. Segundo o autor, "nenhum sobressalto tiveram, antes convieram em vir na canôa ao meu quartel, revestindo-se de tanta confiança e candura, que no embarque lançaram na praia seus arcos e frechas [...]" (BUENO, [1810] 1908, p. 144). Após este encontro fortuito, Bueno solicita ao pequeno grupo de indígenas que dissessem aos seus chefes que viessem ao seu encontro.

No dia seguinte, veio ao encontro de Bueno, um grupo maior de indígenas junto aos seus chefes. Em diversos episódios deste encontro fica claro que este grupo kayapó já estava largamente habituado ao convívio junto aos colonizadores ${ }^{53}$. Com base na data de 1810, quando se deu este encontro, acreditamos que parte deste grupo indígena já havia sido aldeado e que sua procedência era a antiga província de Goiás ${ }^{54}$.

Numa conversa amistosa em que Bueno oferece aos chefes dos Kayapó terras e ferramentas, vislumbramos como se dava a distribuição das aldeias naquele território. Comenta Bueno ([1810] 1908, p. 146):

\begin{abstract}
Depois que os chefes me ouviram, responderam que estavam promptos, porém que os seus indios são sabiam navegar por cachoeiras o que para o anno lhes levasse dez canôas grandes para elles virem, e igualmente viveres; e que além dos de suas aldêas, haviam de convidar a gente de duas aldêas, que ficam acima do Salto de Urubupungá, uma grande e outra menor, ambas do seu commando, para os acompanhar; e que além disto, no Rio Sucuriú haviam três aldêas de muita gente, commandadas por outro chefe, a quem também haviam de convidar para o mesmo fim, e que eu lhes não faltasse.
\end{abstract}

Após dezesseis anos da viagem de Bueno, temos os relatos de Hércules Florence (1875 [1826]), que navegou pelos rios Tietê e Paraná. Seu relato remete à presença de grupos kayapós habitando a região da Foz do Tietê até o Salto de Urubupungá. Caminhando por meia légua da margem do rio Paraná ${ }^{55}$, os viajantes chegam a uma aldeia kayapó. A aldeia foi descrita como "composta de dez palhoças e nas quais não havia viva

\footnotetext{
52 Tesoureiro mór de São Paulo.

${ }^{53}$ É evidente no relato de Bueno que os mesmos estavam acostumados ao tipo de alimentos e às ferramentas que a tripulação trazia, bem como, a eles eram totalmente familiares o culto católico.

${ }^{54}$ Numa conversa entre Bueno e um dos chefes dos Kayapó, o mesmo o informa que "o General de Goyaz (um pequenino) não era bom, porque lhes não dava ferramentas, nem vestuário" (BUENO, 1918, p.146).

${ }^{55}$ Estado de Mato Grosso do Sul.
} 
alma por se acharem os índios nas suas plantações à margem do Sucuriú" (FLORENCE, 1875, p. 389). A casa do chefe era maior que as outras e que ali se encontravam troncos de palmeira furados ${ }^{56}$.

Após algumas vistorias na aldeia, os viajantes deixaram-na, voltando para suas canoas e partindo para o Salto de Urubupungá. Descreveu-o Florence (1875 [1826]) como um estrondoso salto de água com uma largura de quatro léguas, com grande número de saliências e reentrâncias. Cita que, na margem esquerda, havia uns ranchos, feitos pelos Kayapó "de construção muito inferior às míseras choupanas de seu aldeamento. Nada mais eram do que folhas de palmeiras apoiadas em forquilhas de paus" (Ibidem, 1875, p. 390). Quanto a estes "ranchos feitos pelos Cayapó", bem poderia ser um acampamento temporário, próximo ao conjunto de cachoeiras, destinado a alguma atividade específica. Sustentamos essa hipótese pelo fato de Florence mencionar o estado provisório de tais construções, que segundo ele eram inferiores às da aldeia.

O relato de Florence (1875) aponta para uma organização socioespacial configurada por uma aldeia Kayapó, próxima à margem esquerda do Rio Paraná, interligada a uma área de roça à beira do Rio Sucuriú, afluente do Paraná, e acampamento(s) localizado(s) no Salto do Urubupungá. Esta configuração mostra uma rede de exploração ambiental bem estabelecida por: habitação, campo agrícola e acampamento, situados próximos ao grande Salto.

Os relatos históricos mencionados apoiam a hipótese de que, num primeiro momento, a região que engloba a foz do Tietê - Paraná, Salto do Urubupungá ao norte e rio Sucuriú ao sul, era cursada pelos Kayapó Meridional, mas, ainda, não apontavam a presença de habitações. As aldeias começaram a serem descritas na região no ano de 1810, com os relatos de Bueno. Bueno ([1810] 1908) indica que estes grupos vieram de Goiás e, provavelmente, já haviam sido aldeados. Sua organização socioespacial parecia estar bem estabelecida à época, havendo nesta região ao menos sete aldeias, de tamanhos variados e comandadas por apenas dois "chefes", demonstrando um poder político bem constituído.

\subsubsection{Como eram suas aldeias e aldeamentos?}

\footnotetext{
56 Segundo Giraldin (1997), provavelmente, seriam troncos usados nas corridas de toras, típicas dos
} Kayapó. 
O início da fundação dos aldeamentos dos Kayapó Meridional ocorreu no final do século XVIII. A história contada por Saint-Hilaire ([1819] 1937) e Pohl ([1817] 1951) inicia-se com a insurgência de grupos Kayapó, que indomáveis, atacavam as caravanas que se dirigiam a São Paulo, mesmo após a guerra do sertanista Pires de Campos ${ }^{57}$. No ano de 1780, inicia-se o processo de redução dos grupos kayapós que, paulatinamente, após se concentrarem em centenas de indivíduos em Vila Boa de Goiás, são direcionados a um aldeamento nas proximidades.

Segundo consta nas fontes históricas pesquisadas, a Aldeia Maria foi o primeiro aldeamento construído para reduzir os grupos kayapó meridionais de Goiás. Construída no ano de 1781, o aldeamento foi edificado à margem do Rio Fartura, sobre uma colina baixa, pela qual se estende a meia légua de distância, uma paisagem serrana, banhada pelo Rio dos Pilões. No auge de sua ocupação, a Aldeia Maria pôde ter acolhido cerca de 600 pessoas que exerciam diversas atividades no local (AIRES DE CASAL, 1817; POHL, 1951).

Emanuel Pohl (1951) visitou a Aldeia Maria no ano de 1818, quando a mesma já havia sido abandonada há seis anos. Descreve a antiga povoação contendo duas casas térreas, construídas de madeira e barro, cobertas de telhas. Próximo a elas, encontrava-se um paiol para guarda de colheitas, pelo qual em seu entorno dispunham as antigas cabanas dos Kayapó Meridional. Estas estavam configuradas em círculo, enfileiradas uma do lado da outra, tendo o paiol no seu centro. Informa-nos o autor que as cabanas eram construídas da madeira e das fibras das palmeiras.

Tanto Pohl, quanto Saint-Hilaire, visitaram a Aldeia Maria, estando essa totalmente abandonada neste período. No entanto, a aldeia São José de Mossâmedes, nos anos das visitas destes naturalistas ${ }^{58}$, encontrava-se habitada e algumas informações de cunho etnográfico pôde ali ser obtida.

Pohl (1951) diz que a aldeia foi erigida em 1755 e no ano de 1780 foi edificada a igreja. No início a ocupação era destinada às tribos dos Acroá, Javaé e Carajá. Com o desaparecimento destes grupos indígenas nesta região, a aldeia de Mossâmedes ficara vaga e como era mais próxima à Vila Boa de Goiás (capital da província à época) do que

\footnotetext{
57 “Um dos grandes óbices opostos ao povoamento de Goiás proveio da hostilidade dos caiapós, nação numerosa e aguerrida a quem acabou destruindo Antônio Pires dos Campos, o famoso Pay Pirá, em diversas jornadas" (TAUNAY, 1951, p. 189)

${ }^{58}$ Ano de 1817 para Pohl e o ano de 1819 para Saint-Hilaire.
} 
a Aldeia Maria, as autoridades julgaram ser mais econômico transferir os Kayapó daquela para esta.

A implantação do aldeamento aconteceu no cume de uma colina, sendo rodeada por morros. Sant-Hilaire (1937) descreve minuciosamente os edifícios, sua disposição e a organização espacial deste complexo construtivo. Cita que parte desta construção era reservada aos Kayapó, mas que naquela época encontrava-se vazia. Sua narrativa evidencia uma informação importante quanto à ocupação kayapó neste local. A de que eles não habitavam o núcleo do aldeamento. Pohl também sustentou esta mesma informação: "preferem habitar cabanas construídas por eles próprios, de palmeiras e cobertas de ervas [...] construíram-nas do lado ocidental da aldeia e também nas plantações denominadas roças, a uma légua de distância (POHL, 1951, p.360).

Se lembrarmos que os Kayapó da Aldeia Maria habitavam as cabanas construídas de madeira e fibra de palmeira, em formato circular ${ }^{59}$, notaremos que ao serem transferidos para a Aldeia Mossâmedes, eles resistiram em habitar as casas previamente construídas. Este comportamento é registrado por Hilaire: "acostumados, nas florestas, a dormir sob choças, onde não era possível entrar sem abaixar-se, os índios acharam muito frias as casas altas e cobertas de telhas em que queriam alojá-los, e eles próprios construíram outras muito baixas, a pouco passos da aldeia" (SAINT-HILAIRE, 1937, p.107).

A distribuição das casas construídas pelos Kayapó se deu em dois núcleos: O primeiro, próximo ao aldeamento, contendo número de oito a dez casas, e outro, localizado a uma légua, nas suas plantações, tendo esta a maior parte das habitações. Suas plantações ficavam de frente à Serra Dourada e as habitações estavam dispersas entre as árvores. Em seu interior localizam-se "pedras que servem de fogão, cestas de uma forma particular, chamadas jucunús, e, às vezes, giraus, que têm apenas a largura do corpo: nisto consiste o mobiliário de tais choupanas" (Ibidem, 1937, p.111).

Importante salientar que estes dois naturalistas, além de descreverem fisicamente a aldeia Mossâmedes, também trazem importantes anotações sobre a organização social e cultura material deste grupo indígena.

Pohl se ocupa em oferecer relatos sobre o modo de vida dos Kayapó "em estado selvagem", registrando que seus assentamentos se localizam nas extensas matas situadas

\footnotetext{
${ }^{59}$ Como veremos adiante, uma continuidade cultural de quando viviam em suas próprias aldeias.
} 
a sudoeste da aldeia Mossâmedes ${ }^{60}$. Comenta que "ali vagueiam, vivendo da caça, da pesca, de raízes, de mel silvestre etc. Cultivam um pouco de milho de grão negro e azul, que preferem a qualquer outra variedade como o mais rico em farinha [...] em estado selvagem, vivem em poligamia [...] (POHL, 1951, p.363). O autor ainda registra que suas ocupações prediletas consistem em caçar e pescar na mata. "Quando apanham uma peça de caça, o que não é trabalhoso, dada a abundância dela na mata virgem, descansam o dia inteiro; deitam-se e entregam-se à ociosidade" (Ibidem, 1951, p.364). Hilaire vai complementar estas informações básicas, anotando que os Kayapó que vivem na floresta estão "submetidos a um cacique geral que tem sob suas ordens vários capitães: na aldeia os portugueses deram títulos de coronel, capitão, alferes, aos indivíduos mais considerados pelos seus compatriotas [...] (SAINT-HILAIRE, 1937, p.120).

Comenta Saint-Hilaire (1937) que os Kayapó que vivem em estado livre nas matas conhecem apenas a indústria de fazer arcos, flechas e uma espécie de balaio que chamam de juсипú. Salientamos que os mesmos também detinham algum conhecimento no lascamento de cristais de rocha em quartzo. Este fato fica explícito na descrição de Pohl (1951, p.366) de uma atividade que consistia no alívio da dor de cabeça. Quanto ao saber fazer das atividades oleiras, nada conseguimos de informação para este período. $O$ que fica registrado no relato destes viajantes é a descrição de objetos como os jucunús (cestas), bem como, dos itsché (arco) e das caschoné (flechas).

As visitas de Pohl e Saint-Hilaire ocorreram num momento de declínio da ocupação Kayapó no aldeamento de Mossâmedes. Em 1833, boa parte da população havia abandonado Mossâmedes, permanecendo ali, principalmente, os velhos e deficientes. No ano de 1879, o aldeamento de São José de Mossâmedes torna-se oficialmente extinto.

Num segundo momento do processo de aldeamento dos Kayapó Meridional, levantamos informações importantes sobre o estado de Mato Grosso do Sul e Minas Gerais. Segundo os relatos do coronel Ricardo José Gomes Jardim (1869), a povoação que se formou em Santana do Paraíba iniciou-se no ano de 1835 com a vinda de 150 a 160 kayapós, de ambos os sexos, que emigraram das aldeias de Goiás. Segundo as informações obtidas, supomos que neste período estava ocorrendo a emigração de parte dos "fugitivos" de Mossâmedes para esta localidade, situada à margem do Rio Paranaíba, onde hoje é o estado de Mato Grosso do Sul.

\footnotetext{
${ }^{60}$ Estas extensas matas onde se aglomeram os Kayapó coincidem com a região da Serra de Santa Marta e Serra dos Cayapó.
} 
O Aldeamento Santana do Parnaíba recebeu a visita de viajantes no ano de 1857 com o Dr. Kupfer, e em 1882, com o capitão Joaquim Lemos da Silva. Kupfer descreve as casas da vila como construídas de barro e cobertas com folhas de palmeira, existindo a casa dos homens no centro do pátio da aldeia. Na descrição de Lemos, a aldeia é construída na forma tradicional, circular com a casa dos homens no centro do pátio, onde os líderes reuniam-se para deliberar os assuntos da comunidade (GIRALDIN, 1997).

Neste mesmo período, outro aldeamento se formava no mesmo estado. Era a aldeia do Piquiri. Segundo Jardim (1869), a aldeia do Piquiri contava com 300 kayapós, aproximadamente, tendo à frente destas famílias um mesmo chefe a quem elas também obedeciam em Goiás. Pelo relato do autor, este chefe tinha grande poder agregador, pois "tem-se conservado quase todas reunidas" (JARDIM, 1869, p.551). No entanto, estas famílias já haviam abandonado boa parte de sua organização agrícola - "poucos se têm dado aos trabalhos agrícolas" (Ibidem, 1869, p.551) - preferindo os homens da aldeia se embrenharem "no sertão durante parte da boa estação do anno a cata de mel e de caça" (Ibidem, 1869, p.551).

Para os aldeamentos de Minas Gerais, mais especificamente do Triângulo Mineiro, temos a referência do Cônego Antonio José da Silva, que escrevendo de Uberaba, no ano de 1825, afirmava que existiam cerca de mil índios kayapós aldeados a 40 léguas, próximo ao Rio Grande. Alexandre de Sousa Barbosa (1918), agrimensor da região, descrevera que existiam ao menos três aldeamentos no Triângulo Mineiro, entre eles, dois localizavam-se na margem direita do Rio Grande, no Arraial de São Francisco Salles e o aldeamento de Água Vermelha (BARBOSA, 1918; GIRALDIN, 1997).

No ano de 1871, a Diretoria Geral dos Índios de Minas Gerais informava que, no aldeamento de São Francisco Salles, existia um total de 118 índios, que nesse momento a estavam deixando para se mudarem para um local chamado Cachoeira, provavelmente, Cachoeira da Água Vermelha, na margem do Rio Grande (GIRALDIN, 1997).

No ano de 1911, Alexandre de Souza Barbosa encontra na região oeste do Triângulo Mineiro, na confluência dos rios Paranaíba e Grande, um grupo de índios kayapós, oriundos da aldeia Água Vermelha, na época localizada na comarca de Frutal (MG). Salientou o agrimensor que esse grupo kayapó se autodenominava Panará (BARBOSA, 1918). Segundo consta em seu manuscrito, intitulado "Cayapó e panará”, Barbosa (1918) recebe informações de que há cerca de trinta anos ${ }^{61}$ :

\footnotetext{
${ }^{61}$ Portanto, no ano de 1881.
} 
[...] os indios de Agua Vermelha andavam apenas nus.

Nas terras da aldeia poucos plantam, não possuem gado e sua principal alimentação é fornecida pela pesca no rio Grande.

Fazem em suas terras paulistas desabitadas à margem esquerda deste rio pequenas roças para ceva da caça.

[...]. Informaram-nos que havia antigamente no centro da aldeia uma casa maior que as outras e a que chamavam piruá, onde se tomavam de grandes deliberações [...] e se celebravam as festas e os casamentos sob as ordens do capitão, este em tudo, cegamente obedecido. (BARBOSA, 1918, p.10).

Neste período, da década de 1880, a população kayapó-panará em Água Vermelha era de, aproximadamente, 600 habitantes. No entanto, na data do registro de Barbosa (1918), no ano de 1911, esta população estava reduzida a apenas 50 indivíduos.

Posteriormente, informações orais coletadas das cidades próximas de onde se localizava a aldeia Água Vermelha dão conta da presença dos remanescentes das aldeias Kayapó-Panará daquela área, ainda na década de 1960. O relato oral de um marceneiro de Uberaba, coletado pela pesquisadora do arquivo de Uberaba, Sônia Maria Fontoura, conta que em idade de doze anos seu pai o levara para pescar no Rio Grande e que, além do aldeamento Água Vermelha, existiam outras aldeias mais abaixo, num local chamado Canal de São Simão. Na primeira aldeia, as casas estavam dispostas em círculo, mas na última, elas estavam em linha reta (GIRALDIN, 1997).

Um dos últimos relatos que fazem menção aos Kayapó-Panará na região do Triangulo Mineiro foi registrado por engenheiros da Comissão Geográfica e Geológica de São Paulo, que, no ano de 1913, realizaram a exploração cientifica do Rio Grande e de seus afluentes. Contam-nos os engenheiros Guilherme Wendel e Arthur Horta O’Leary (1913) que eles receberam a visita de alguns índios, próximo ao Salto da Água Vermelha (SP). Estes índios os informaram de que tinham sua moradia numa aldeia pouco abaixo do salto, no lado mineiro ${ }^{62}$. Segundo os engenheiros, estes indígenas antigamente "viviam em suas terras entre o porto da Aldêa e a cachoeira dos Índios, já há mais de uma geração mudaram-se para Agua Vermelha" (COMISSÃO GEOGRÁFICA E GEOLÓGICA DO ESTADO DE SÃO PAULO, 1913, p. 14-15).

Estas informações fornecidas pelos engenheiros da Comissão Geográfica e Geológica narram a movimentação dos Kayapó-Panará do aldeamento de São Francisco Salles para o de Água Vermelha. Um marcador de paisagem importante, dentre estas duas

${ }^{62}$ Com base no referencial geográfico e temporal, estes índios, nesta época, ocupavam a Aldeia Água Vermelha. 
antigas ocupações kayapós, era que ambas estavam instaladas na margem mineira do Rio Grande, muito próximas de grandes saltos ou cachoeiras, sendo a de São Francisco Salles chamada de Cachoeira dos Índios e a do aldeamento de Água Vermelha chamado de Salto da Água Vermelha.

\subsubsection{Considerações sobre os aspectos socioespaciais dos Kayapó Meridional}

O produto desta pesquisa bibliográfica se configura como importante fonte documental a respeito dos Kayapó Meridional, demonstrando a complexidade histórica e socioespacial deste grupo. Nas considerações finais elaboramos uma síntese que poderá fornecer um cabedal de informações e desdobramentos para diversas disciplinas sociais.

O território kayapó meridional era vasto, se estendendo ao norte até a Serra Dourada (Goiás), ao oeste pela Serra Santa Marta e dos Caiapós (Goiás) até a cabeceira dos rios Piquiri e Taquari (Mato Grosso do Sul), ao sul até o Rio Pardo, afluente da margem direita do Rio Paraná (Mato Grosso do Sul - São Paulo) e a leste, englobando todo o Triângulo Mineiro até o Rio das Velhas (Minas Gerais).

Figura 13 - Território Kayapó Meridional

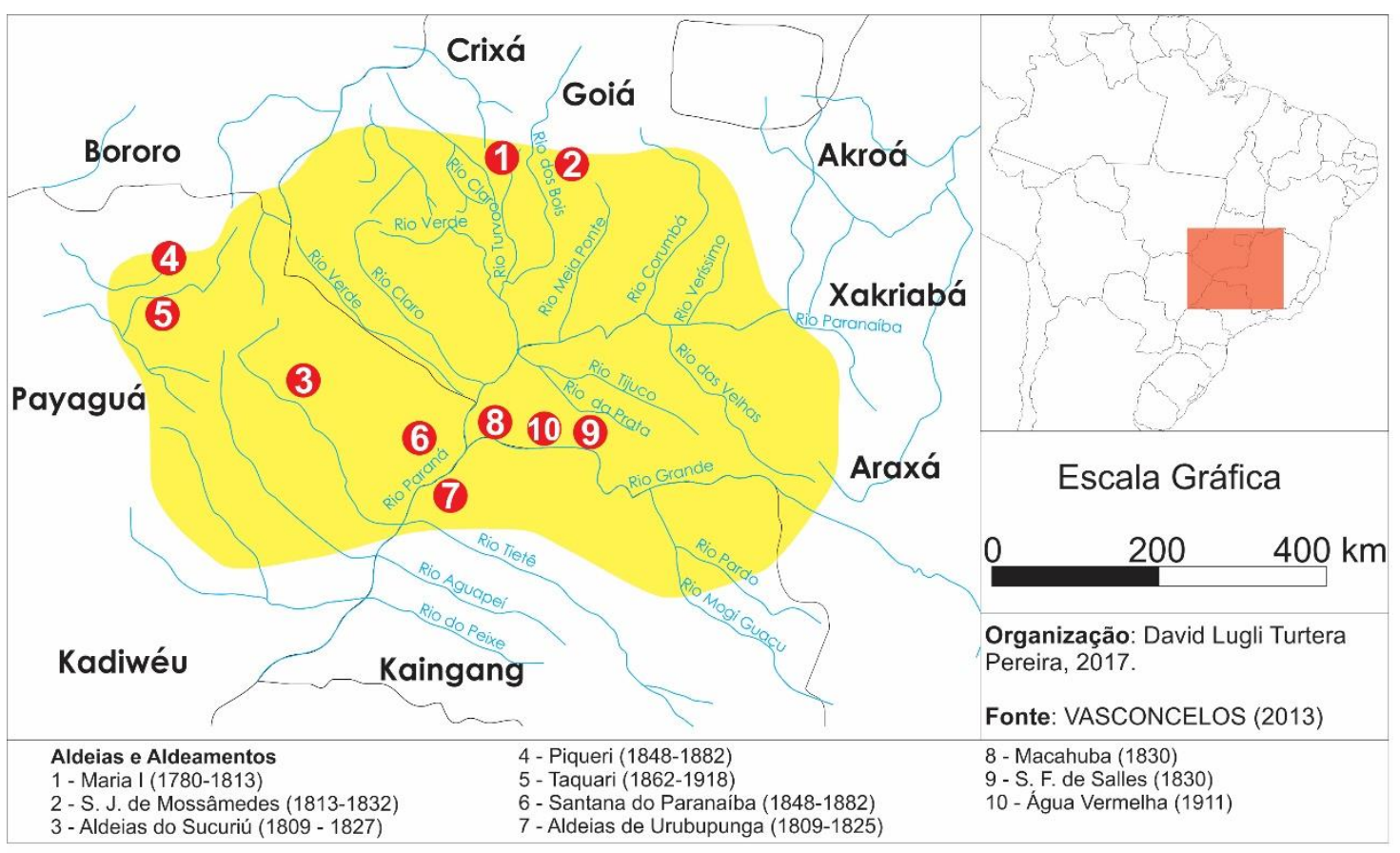

Fonte: Vasconcelos (2013).

Os primeiros relatos dão conta de um grande contingente populacional; diversas aldeias espalhadas pelo território e uma organização política bem estabelecida, tendo em 
alguns casos uma única chefia para várias aldeias. Com a intensificação do empreendimento colonial e a desapropriação de grupos de kayapós de suas terras tradicionais, os mesmos começam a emigrar para outras áreas de seu território, se reorganizando socioespacialmente em algumas décadas.

A movimentação deste grupo por seu território pôde ser observada nos documentos históricos. Neste aspecto, ponderamos algumas estratégias de mobilidade socioespacial: 1- movimentaram-se dentro de seu próprio território para fugir da pressão colonial, defendendo-se topograficamente nas serranias do sudoeste de Goiás ou migrando para o Rio Paraná, na altura do Salto do Urubupungá; 2- a desterritorialização provocada pelo avanço colonial implicou numa reterritorialização kayapó; 3- a reterritorialização kayapó reconfigurou socioespacialmente algumas áreas que tinham uma função dentro do território, passando a ter outra.

É recorrente nos documentos históricos, a descrição dos Kayapó Meridional organizados em aldeias, de tamanhos distintos, tendo cada aldeia seu próprio "chefe", havendo em alguns casos, relatos de lideranças regionais, englobando várias aldeias. A distribuição destas aldeias, geralmente, é caracterizada pela proximidade aos grandes rios e seus afluentes, bem como, aos marcadores de paisagem como cachoeiras (Urubupungá, SP-MS; Salto dos Índios e Vermelha, MG-SP) e serras (Caiapó, Santa Marta e Serra Dourada, GO). Outro padrão observado no assentamento destes grupos foi a formação de uma rede englobando habitação, roças e acampamento.

A configuração das aldeias e aldeamentos aponta algumas características comuns. Estas características são marcadores socioespaciais dos grupos kayapós meridionais. São eles: 1- recepção de embarcações em um "porto" instalado num grande rio (como o rio Paraná ou o Grande), próximo a saltos/cachoeiras, 2- aldeias e aldeamentos ${ }^{63}$ apresentando formato circular, com a casa dos homens no centro (ou piruá), exibindo número de oito a dez casas, 3- população variando entre 150 (Santana do Paranaíba/MS) a 600 (Aldeia Água Vermelha/MG) pessoas por aldeamento ${ }^{64}$, 4- no geral, as casas eram confeccionadas com embira, folhas e fibras de palmeira buriti (Mauritia Vinífera).

Outra característica socioespacial a mencionar é a mobilidade de subsistência kayapó. Neste aspecto, suas roças eram caracterizadas pelo cultivo de milho (grão negro

\footnotetext{
${ }^{63}$ Neste caso pondera-se que algumas áreas dentro dos aldeamentos foram construídas pelos próprios Kayapó. Estas áreas geralmente eram preferidas por eles para morar ou acampar de forma sazonal.

${ }^{64}$ Consta nos documentos históricos apenas referência populacional para os aldeamentos.
} 
e azul), batata e outros cultígenos. Geralmente, as roças ficavam distantes da aldeia. SaintHilaire ([1847] 1937) fala em uma légua de distância. Em outro caso, como mencionado por Barbosa (1918), as roças eram abertas perto da margem de um grande rio (neste caso o Rio Grande no lado paulista) para a ceva da caça. Praticavam atividades de caça (abundância na mata virgem) e coletas (raízes e mel silvestre). Segundo as fontes, as excursões de caça e coleta percorriam extensas áreas de seu território, sendo que elas poderiam durar meses e se estenderem para locais centenas de quilômetros longe da aldeia. A pescaria era tida como atividade de suma importância na bacia dos rios Grande e Paraná. Barbosa (1918) assinala que a principal alimentação de um grupo kayapó era fornecida pela pesca no rio Grande. E Florence (1875) aponta os ranchos instalados a margem do Salto de Urubupungá.

Este levantamento bibliográfico é um primeiro passo para o ordenamento das fontes etno-históricas sobre este grupo que habitou, por pelo menos 200 anos, uma vasta área que englobava parte do centro-sul brasileiro. Informações de sítios arqueológicos estabelecidos nesta extensa área, apresentando datações recentes, podem ser confrontadas aos dados históricos aqui compilados. A ideia é entender como grupos indígenas ordenaram seu território e se organizaram socioespacialmente durante os últimos séculos. 
CAPÍTULO 3

O CONTEXTO DOS SÍTIOS ARQUEOLÓGICOS 
O objetivo de contextualizar a área de pesquisa desta tese respalda-se na caracterização da matriz ambiental (meio físico-biótico) das transformações que esta matriz ambiental sofreu com o processo de ocupação e das características dos sítios arqueológicos trabalhados.

Os dados levantados formam um referencial informativo que embasa nossa pesquisa arqueológica, realizada na bacia hidrográfica do Rio Turvo-Grande. Esta pesquisa enfoca a interface entre arqueologia e geografia e toma a paisagem como unidade geográfica que aproxima os artefatos, sítios e o ambiente (MORAIS, no prelo). Essa aproximação é essencial para a contextualização da pesquisa e para a criação de diversas inferências de dados, incluindo história de ocupação, mudança populacional, sistema de assentamento e subsistência, reconstrução da paisagem e processos ambientais em níveis regionais (MORAIS, no prelo, 1999; SCHIFFER et. al., 2010).

Nessa unidade dimensional, compreendida por centenas de quilômetros quadrados, situam-se os processos de interferência e interação entre o potencial ecológico, a exploração biológica e a ação antrópica. Estes, por sua vez, são dados instáveis que variam, tanto no tempo como no espaço, formando os diversos estágios do desenvolvimento de uma paisagem, a partir de uma série dinâmica (BERTRAND; BERTRAND, 2007; BUTZER, 2006).

\subsection{O contexto ambiental}

Consonante à classificação paisagística de Ab’Saber (1982, 2006), a bacia hidrográfica do Rio Turvo-Grande situa-se em uma faixa de transição entre o domínio ${ }^{65}$ dos Mares de Morros $^{66}$ e o domínio do cerrado ${ }^{67}$. A área mais típica e contínua de um domínio é denominada de área nuclear. Entre as áreas nucleares de determinados domínios, existe sempre um espaço de transição e de contato, que afeta de modo mais sensível os componentes da vegetação, os tipos de solos e sua forma de distribuição e, até

\footnotetext{
${ }^{65}$ Por domínio morfoclimático e fitogeográfico, entende-se um conjunto espacial de certa ordem de grandeza, variando de centenas de milhares a milhões de quilômetros quadrados de área, onde existe uma configuração coesa de feições de relevo, tipos de solos, formas de vegetação e condições climáticas e hidrológicas (AB'SABER, 2006).

${ }^{66} \mathrm{O}$ domínio dos mares de morros florestados apresenta fortíssima e generalizada decomposição de rochas, densas drenagens perenes, planícies meândricas, solos superpostos e florestas tropicais, recobrindo setores serranos mamelonizados dos planaltos do sudeste do Brasil (AB'SABER, 1967; 2003).

${ }^{67} \mathrm{O}$ domínio do Cerrado é marcado por planaltos sedimentares com vertentes em rampas suaves, cobertos por vegetação de cerradões, cerrados e campos nos interflúvios, e de florestas galerias no fundo dos baixos vales. Apresenta cabeceiras de drenagem com anfiteatros pantanosos, pontilhados por buritis e predomínio de latossolos, em geral de fraca fertilidade primária (AB'SABER, 1967, 2003).
} 
certo ponto, as próprias feições de detalhe do relevo regional. Esses setores de transição e contato apresentam combinações morfoclimáticas e fitogeográficas diferentes das áreas nucleares, o que permite visualizar uma singularidade biogeográfica em cada combinação.

Se recortarmos esse setor de transição para o norte do estado de São Paulo, este coincidiria com a região do Planalto Ocidental Paulista, que é constituído por diversas formações geológicas, predominantemente areníticas e com basaltos expostos nos vales dos principais rios. O relevo apresenta-se levemente ondulado, com predomínio de colinas amplas e baixas, com topos aplanados (IPT, 1981b). As formações florestais predominantes no Planalto Ocidental Paulista são delineadas pela relação entre os solos, a posição topográfica e o sistema hídrico local, sendo classificadas como floresta estacional semidecidual, cerrado e cerradões (BORGONOVI; CHIARINI, 1965; KASHIMOTO, 1997; THOMAZ, 2002).

A bacia hidrográfica do Turvo-Grande, inserida nesse contexto, apresenta peculiaridades ambientais que serão abaixo descritas:

\subsubsection{Clima}

O clima é agente fundamental na compreensão da paisagem, tanto fornecendo insumos de energia para a comunidade biótica, quanto como regulador dos processos inerentes. Configurações espaciais determinadas pela topografia do terreno, formação e cobertura do solo, rede de drenagem e escoamento pluvial e hídrico, interagem com os padrões climáticos regionais, que por sua vez resultam na configuração do estágio de desenvolvimento de uma paisagem (SANT'ANNA NETO, 1998).

Em termos gerais, a B. H. do Turvo-Grande apresenta-se como uma das regiões mais quentes do estado de São Paulo, com tipo tropical chuvoso e com inverno seco e frio. O mês mais frio (julho) possui temperatura média superior a $18^{\circ} \mathrm{C}$ e o mês mais seco (agosto) tem precipitação média inferior a $20 \mathrm{~mm}$. Os meses mais quentes possuem temperatura média acima de $25^{\circ} \mathrm{C}$ e o mês mais chuvoso (janeiro) tem precipitação acima de 240 mm (Em: http://www.cepagri.unicamp.br/. Acesso em 12 de Junho 2015).

O clima tropical quente e úmido dessa região caracteriza-se por três meses de baixa pluviosidade (junho, julho e agosto), com média próxima de $20 \mathrm{~mm}$ por mês, e três meses de alta pluviosidade (dezembro, janeiro e fevereiro), com média próxima a 200 mm por mês (CASTRO et. al., 2004). As regiões norte e noroeste do estado de São Paulo 
apresentam grande variabilidade sazonal de chuvas e os menores índices totais pluviais com 1282 mm/ano (NERY et. al., 2004).

\subsubsection{Topografia, geologia e pedologia}

Em síntese, topografia, geologia e pedologia formam uma unidade geográfica que engloba os principais aspectos físicos da litosfera e se relacionam de forma interdependente com o clima e a comunidade biótica. A relação entre geologia e topografia faz predominar, em nossa área de estudo, colinas amplas sobre rochas basálticas e areníticas. Essas colinas amplas apresentam declividades de até 15\%, amplitude altimétrica local inferior a 100 metros, topos extensos e aplainados, vertentes com perfis retilíneos a convexos, drenagem de baixa densidade e vales abertos a fechados, como podemos visualizar na Figura 14 (Disponível em:http://fflorestal.sp.gov.br/files/2012/01/EEPaulodeFaria/EncartesPMEEF/ENCART E3fim1.pdf. Acesso em: 23 Julho de 2015).

No curso médio do Rio Grande, na B. H. Turvo-Grande, seus afluentes esquerdos, como o Rio Turvo, escoam sobre terrenos basálticos oriundos da Formação Serra Geral (K1_beta_sg) e por depósitos de arenitos finos da Formação Adamantina (K2vp). As erupções básicas compreendem um conjunto de derrames de basaltos intercalados por arenitos, com coloração cinza a negra para os basaltos, e arenitos intertrapeanos finos e médios de estratificação cruzada, como podemos visualizar na Figura 15 (Disponível em:http://fflorestal.sp.gov.br/files/2012/01/EEPaulodeFaria/EncartesPMEEF/ENCART E3fim1.pdf. Acesso em: 23 Julho de 2015).

Em função do material geológico de origem, topografia, clima e organismos, são formados os diferentes tipos de solos, com base em processos dos quais decorrem inúmeras modificações no aspecto físico e na composição química dos minerais. Extensas manchas de Latossolo Vermelho localizam-se a nordeste da B. H. Turvo-Grande, sobre as rochas basálticas a areníticas, em colinas amplas e médias, como podemos visualizar no Mapa (LEPSCH, 2002).

O Latossolo Vermelho apresenta argilas predominantemente do tipo caulinita, revestidas por óxidos de ferro, responsáveis por sua coloração avermelhada. Sua textura uniforme é composta de agregados com formato arredondado e tamanho pequeno $(0,5 \mathrm{a}$ $3,0 \mathrm{~mm}$ ), estruturados de modo a deixar uma grande quantidade de macroporos entre eles, o que proporciona uma alta permeabilidade à água, mesmo com elevados teores de argila. 
São pobres em nutrientes vegetais, quando encontrados em regiões quente e permanentemente úmidas, costumam embasar vegetação de densa floresta, com quantidade mínima de nutrientes, reciclados sazonalmente pela vegetação. Em regiões com longa estação seca, desenvolve-se vegetação pouco densa, como Cerrado e Cerradões (LEPSCH, 2002).

\subsubsection{Vegetação e fauna}

Em função dos processos antrópicos causados pelo histórico de ocupação da região em apreço, atualmente os remanescentes de vegetação natural estão praticamente dizimados, cobrindo aproximadamente $4 \%$ da B. H. Turvo-Grande. A distribuição da cobertura vegetal, em seu sentido mais amplo, pode ser denominada de Cerrado, Cerradão e Floresta Estacional Semidecidual, conforme a Figura 16 (STRANGUETTI; RANGA, 1998).

Manchas de Cerrado foram identificadas próximas ao Baixo-Turvo, enquanto o cerradão se fez presente no Médio-Turvo (BORGONOVI; CHIARINI, 1965). O Cerrado (savana) no estado de São Paulo caracteriza-se por apresentar vegetação xeromorfa com árvores e arbustos de aspecto tortuoso, geralmente encontrada em Latossolo Vermelho Amarelo, fase arenosa, ou Latossolo Vermelho - Roxo (eutroférricos) de baixa fertilidade.

No caso do Cerradão (savana florestada), refere-se à cobertura vegetal que se caracteriza por uma razoável série de espécies vegetais com porte em torno de 10 metros de altura. Sua estrutura básica é composta de um andar de árvores esparsas que podem alcançar 15m, abaixo vêm arbustos com o máximo de 3m, mais denso, e, posteriormente, as gramíneas. Essa cobertura vegetal recobre os mesmos solos mencionados para o Cerrado (BORGONOVI; CHIARINI, 1965; LEPSCH, 2002).

A Floresta Estacional Semidecidual encontra-se em melhor estado de preservação e concentração na Estação Ecológica de Paulo de Faria - SP. Esse tipo de cobertura vegetal desenvolve-se em ambientes menos úmidos do que aqueles onde cresce a Floresta Ombrófila Densa. Ocupam ambientes que transitam entre uma zona úmida e o ambiente semiárido. Seu porte de aproximadamente 20 metros apresenta uma razoável perda de folhas no período seco, notadamente no estrato arbóreo. Na época chuvosa, sua fisionomia confunde-se com a Floresta Ombrófila. Geralmente cobrem os Argissolos e 
Latossolos, ambos Vermelho - Amarelos, com baixa fertilidade natural (BORGONOVI; CHIARINI, 1965).

No levantamento florístico de algumas espécies da Floresta Estacional Semidecidual, localizada no perímetro da Estação Ecológica de Paulo de Faria - SP, realizado por Stranguetti e Ranga (1998), foram detectados tipos de árvores da família Annonaceae (ex. Araticum), Apocynaceae (ex. Peroba), Anacardiaceae (ex. Aroeira), Bignoniaceae (ex. Ipê Branco), Bombacaceae (ex. Paineira), Lauraceae (ex. Canela de folha grande), Lecythidaceae (ex. Jequitibá), Leguminosae Caesalpinoideae (ex. Pata de vaca, Copaíba e Jatobá), Mimosoideae (ex. Monjoleiro, Farinha seca, Angico vermelho, Ingá), Meliaceae (ex. Cedro e Catiguá), Moraceae (ex. Figueira), muitas delas oferecendo matéria prima para alimentação humana e de animais, lenha e madeira, bem como, resinas.

O levantamento faunístico realizado pela CESP, no ano de 1978, à época das obras para a construção da Represa Água Vermelha nos municípios de Indiaporã, Mira Estrela, Macedônia, Cardoso, Riolândia e Paulo de Faria, no estado de São Paulo, identificou a existência de cachorro do mato, caititu, capivara, cervo, cotia, mico, paca, quati, queixada, tatu-bola, tatu-canastra, veado. Da avifauna foi identificada a presença de anu, araçuá, araponga, azulona, codorna, garça, jaburu, jacu, jaó, macuquinho, martim pescador, mutum, papagaio, perdiz, pato, periquito, siriema. Da fauna aquática, foram levantadas as seguintes espécies: bagre-branco, bagre-ourubim, barbudinho, cascudo, corimbatá, dourado, lambari, pacu, piaba, piapara, traíra, traíra-açu (Disponívelem:http://fflorestal.sp.gov.br/files/2012/01/EEPaulodeFaria/EncartesPMEE F/ENCARTE3fim1.pdf. Acesso em: 23 Julho de 2015).

A primeira aproximação de um quadro ambiental da Bacia Hidrográfica do TurvoGrande foi delineada nos parágrafos antecedentes. Essa abordagem permite esboçar de forma genérica as características dos aspectos bióticos e abióticos responsáveis por influenciar, contribuir e relacionar os processos de ocupação e modificação humana na paisagem ao longo da história. 
Figura 14 - Distribuição dos Sítios Arqueológicos e Áreas de Ocorrência nas classes geomorfológicas
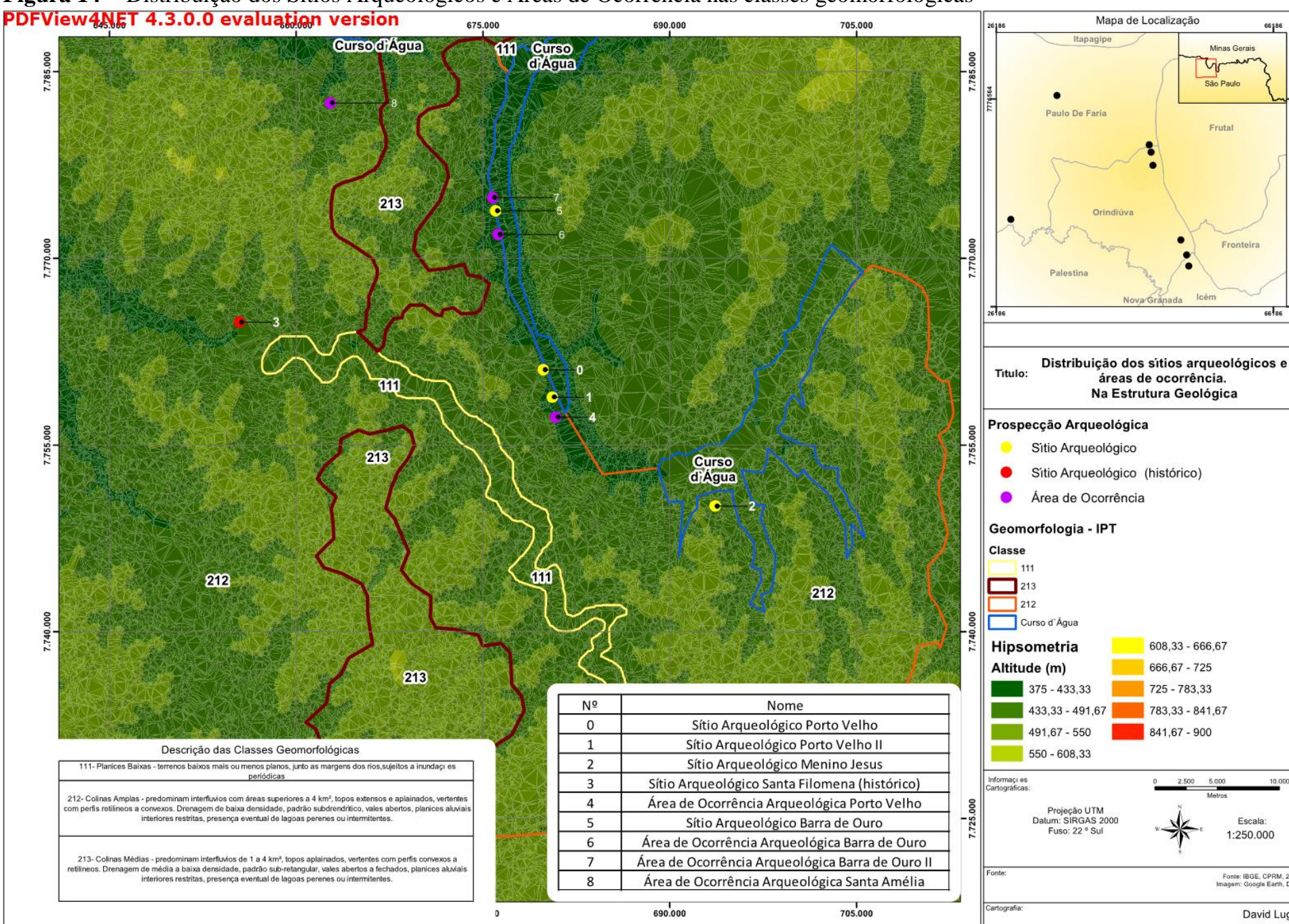

Titulo: Distribuição dos sitios arqueológicos e áreas de ocorrência.
Na Estrutura Geológica

Prospecção Arqueológica

Sitio Arqueológico

- Sitio Arqueológico (histórico)

- Área de Ocorrência

Geomorfologia - IPT

Classe

$\square_{213}^{113}$

$\Longrightarrow$ Curso o'Aagua

Hipsometria $\quad 608,33-666,67$

\begin{tabular}{l|l}
\hline Altitude $(m)$ & $666,67-725$ \\
\hline
\end{tabular}

$\begin{array}{ll}375-433,33 & 725-783,33\end{array}$

\begin{tabular}{|c|c|c|}
\hline $375-433,33$ & $725-783,33$ \\
\hline $433,33-491,67$ & $783,33-841,67$
\end{tabular}

491,67-550 $841,67-900$

] $550-608,33$

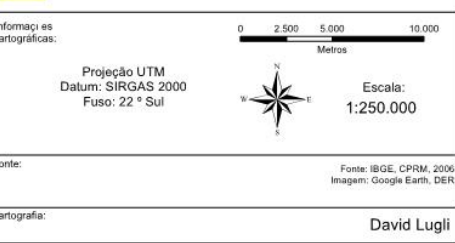

Fonte: IBGE; CPRM, 2006. Imagem Google Earth DER. Confecção: Tadeu Gasparetto e David Pereira. 
Figura 15 - Distribuição dos Sítios Arqueológicos e Áreas de Ocorrência nas estruturas geológicas

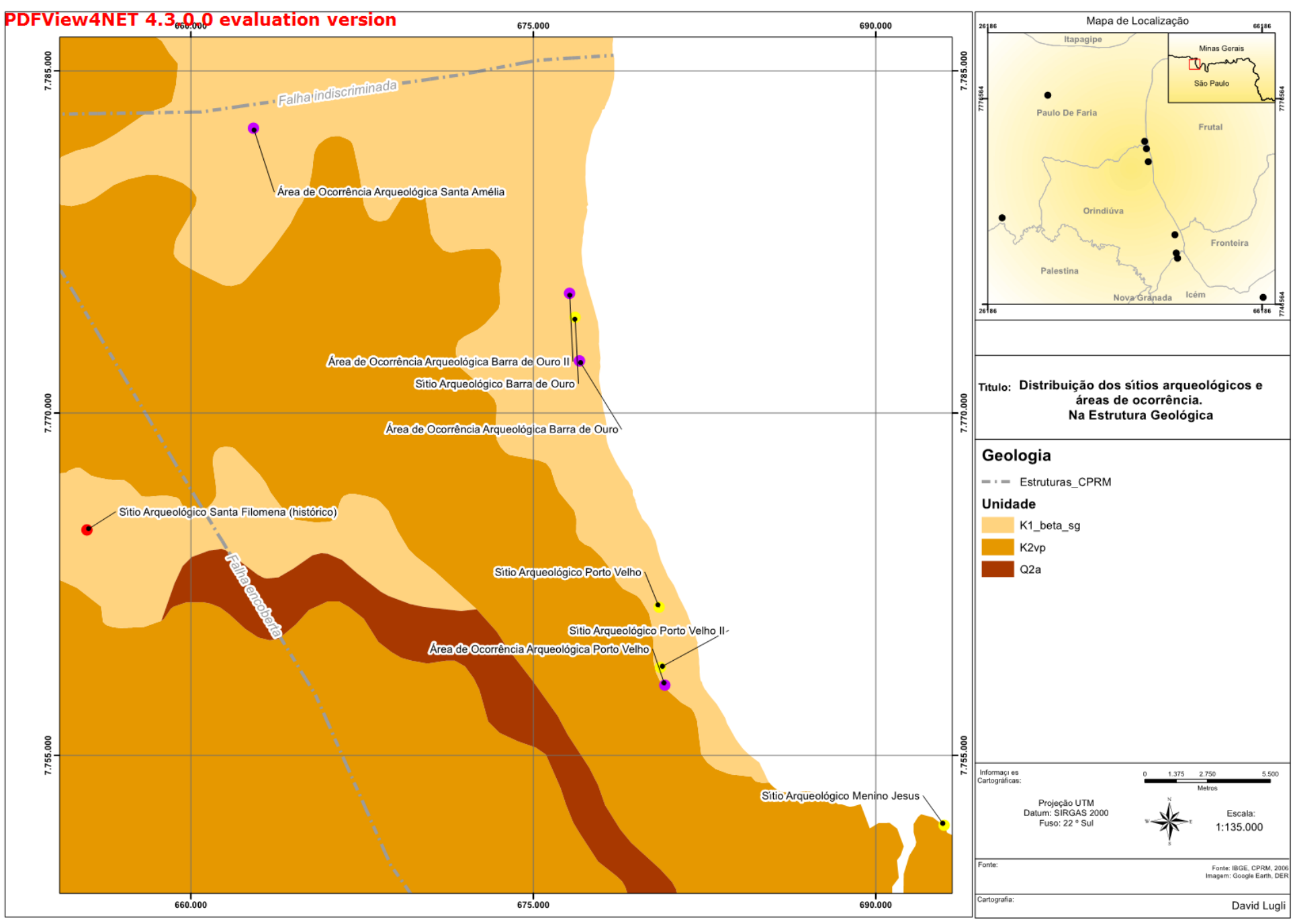

Fonte: IBGE; CPRM, 2006. Imagem Google Earth DER. Confecção: Tadeu Gasparetto e David Pereira. 
Figura 16 - Distribuição dos Sítios Arqueológicos e Áreas de Ocorrência na cobertura pedológica

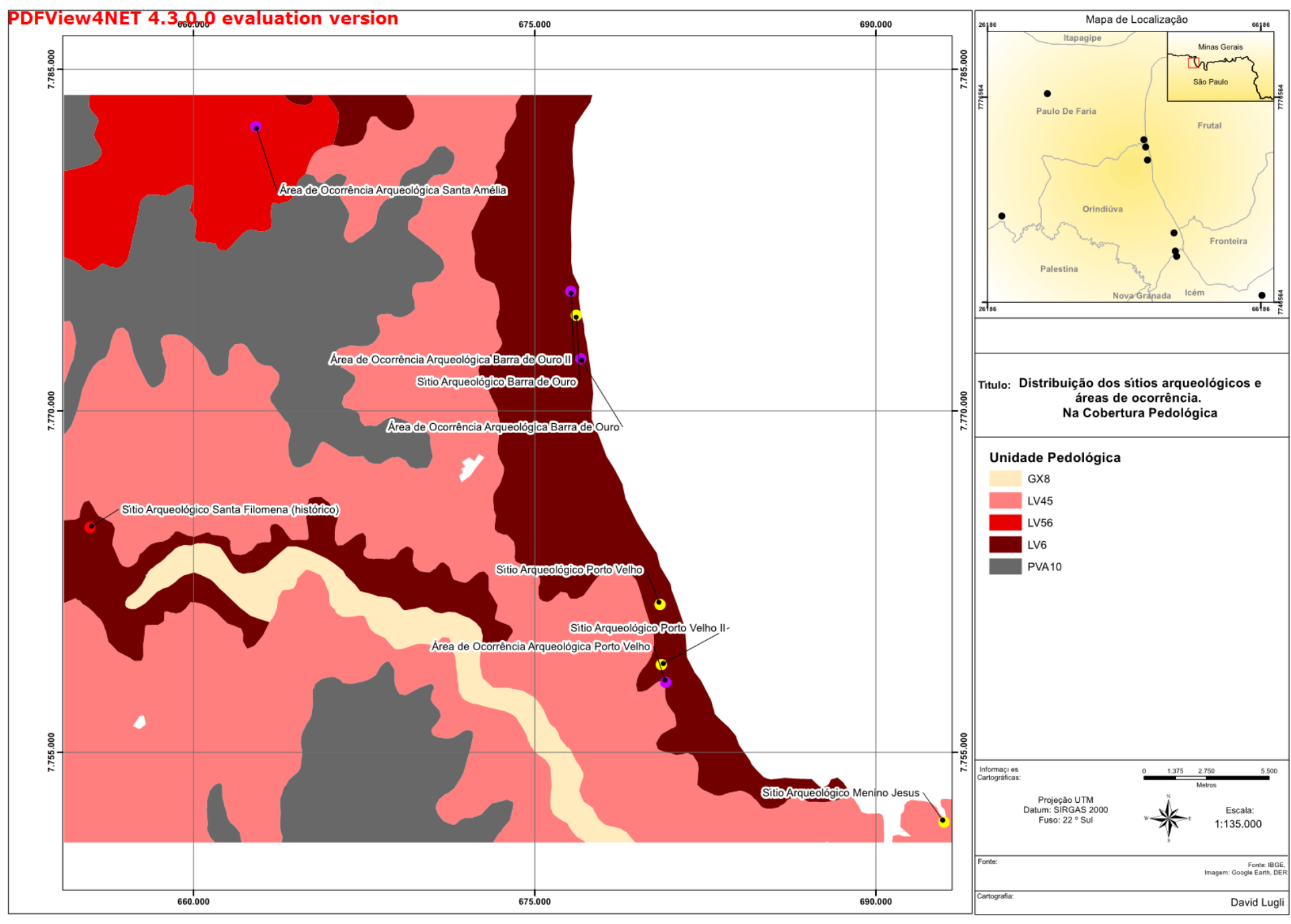

Fonte: IBGE; CPRM, 2006. Imagem Google Earth DER. Confecção: Tadeu Gasparetto e David Pereira. 
Figura 17 - Distribuição dos Sítios Arqueológicos e Áreas de Ocorrência na cobertura vegetal

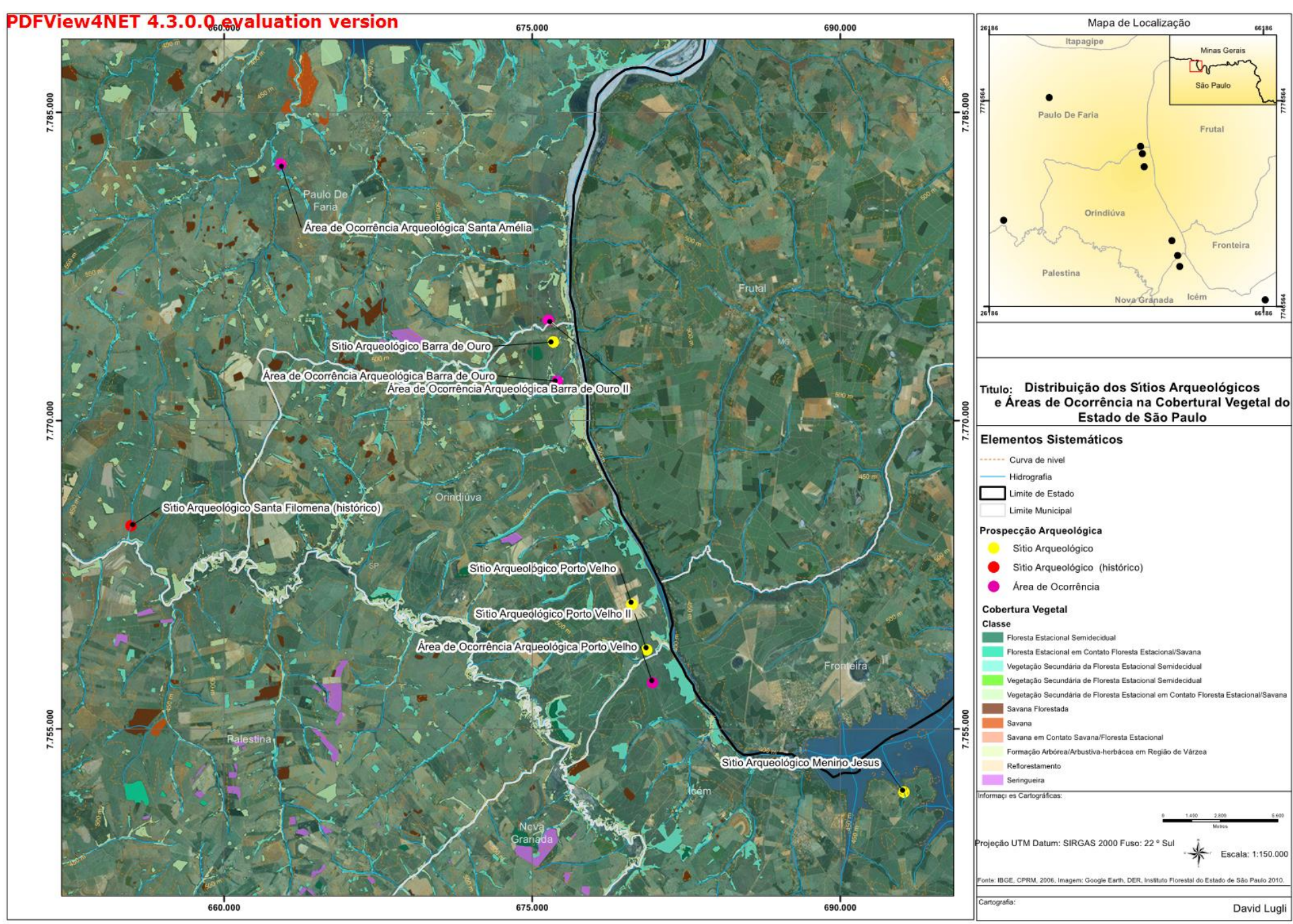

Fonte: IBGE; CPRM, 2006. Imagem Google Earth DER. Confecção: Tadeu Gasparetto e David Pereira. 


\subsection{Colonização e transformação da paisagem}

Segundo consta nos trabalhos de Monbeig (1984), grupos indígenas denominados Kayapó, no fim do século XIX e início do XX, dominavam parte do Planalto Ocidental Paulista, entre o Rio Grande e o Tietê. $\mathrm{O}$ autor ressalta que devido às matanças, epidemias e ao avanço da colonização e ocupação dessas terras, esses grupos foram aniquilados. Serviços de proteção, organizados pelo General Rondon e pelo governo do estado, reagruparam as raras famílias sobreviventes em alguns postos, sendo os mais numerosos ao longo da ferrovia noroeste.

Inaugurava-se, nesse período, a marcha pioneira que marcou a ofensiva contínua nas florestas e territórios indígenas dos "sertões" de São Paulo, implantando uma cultura devastadora, que em curto período modificou as paisagens e reestruturou todo o sistema econômico dessa região. A nova marcha pioneira desdobrava-se de Minas Gerais em direção a São Paulo, projetada pela crise econômica acarretada pela decadência da mineração. A migração se deu primeiramente nas áreas onde os cafezais começavam a notabilizar-se em grandes contingentes, primeiramente no sopé dos contrafortes da Mantiqueira, depois mais ao norte, nas cidades de Franca e Barretos (MONBEIG, 1984). A migração e o povoamento reforçaram o princípio básico do domínio sobre a natureza, onde novas terras e novos bens abrem-se à pretensão dos colonizadores (BOSI, 1993).

De fato, as maiores levas migratórias fixaram-se nos municípios onde a lavoura de café estava estabilizada, mas houve aqueles que procuravam as terras mais longínquas, onde poderiam instalar suas criações em grandes espaços. Assim, no ano de 1852, assentaram-se as primeiras cabanas pioneiras, onde hoje é São José do Rio Preto e nas regiões vizinhas. Em 1870, estradas uniam o vilarejo de Rio Preto ao Triângulo Mineiro e Mato Grosso, tendo na época toda a margem esquerda do Rio Grande recebido forte contingente de mineiros (MONBEIG, 1984). Os criadores de gado e porcos da região de Rio Preto fundaram diversos núcleos de povoamento, estabelecidos nas manchas de campos e cerrados, penetrando nas matas apenas quando houve a possibilidade da cultura do café se estabilizar na região, com a aproximação da estrada de ferro (Ibidem, 1984).

\subsubsection{Agricultura de subsistência, a lavoura de algodão e a pecuária}

A tríade agricultura de subsistência, lavoura de algodão e pecuária intensificaramse no norte/noroeste Paulista após a quebra das bolsas de valores de 1929, instalando uma 
crise econômica mundial que se refletiu na economia e na sociedade paulista, materializada na diminuição da importância da cultura do café no estado. A substituição da cultura de café nessa região paulista levou à reestruturação das propriedades rurais, resultando em seu parcelamento. A título de exemplo, até 1950, no sertão de Rio Preto, havia uma dúzia de glebas que variavam de 15.000 a 208.000 alqueires (www.fflorestal.sp.gov.br).

Essas imensas glebas eram na verdade enormes extensões de terras florestadas, pouco cultivadas, que a partir da especulação de 1950, foi conduzida a uma divisão sucessiva, gerando dois tipos distintos de propriedades: a fazenda e o loteamento para o pequeno proprietário. O fracionamento das glebas, ocasionado pelo afluxo de pioneiros, por sua vez, auxiliados pela construção do trecho da estrada de ferro Noroeste Brasil (ver Figura x), fez com que fazendeiros de café, criadores de gado e sitiantes, paulatinamente, ocupassem essas terras. O traçado dos lotes fracionados das glebas permitiu tanto aos fazendeiros, quanto aos sitiantes, o acesso concomitante à água e ao espigão, em terrenos estreitos e compridos (MONBEIG, 1984).

Os lotes fracionados em fazendas ou loteamentos eram então desflorestados, acabando com a cobertura vegetal original de matas e cerrados, onde se implantava o cultivo de algodão ou culturas de subsistência. Depois de alguns anos de cultivo, uma vez queimadas as plantas da última safra (lavoura de algodão), ocorre o plantio de espécies forrageiras que resultarão em pasto. Em seguida, os animais são introduzidos nas pastagens. A renovação das gramíneas ocorre com o manuseio do fogo, visando uniformizar os campos, onde os tufos de capim deverão ter a mesma altura. A velocidade do processo antrópico e a destruição da floresta ocorrem em ritmo rápido, sendo, a exemplo, uma propriedade de 220 alqueires desbravada em um ano, reduzida a 70 alqueires de floresta, enquanto o restante é transformado em roças. Em quatro anos, tanto a floresta remanescente, quanto as roças, são transformadas em pastagem, num processo de devastação que varreu o noroeste paulista (Ibidem, 1984).

Os implementos agrícolas utilizados à época das primeiras lavouras eram em grande parte manuais, constituídos, sobretudo, pelo uso da enxada. A partir de alguns anos, quando os juncos dos escombros da floresta são removidos, era possível lavrar a terra com o arado leve sem roda e de manuseio fácil. A carpideira com três ferros dispostos em triângulo poderia cavar três sulcos ao mesmo tempo. Nas fazendas, sobretudo nos cafezais remanescentes, ocasionalmente ocorria o serviço do arado com 
ferro mais profundo e complementado por um tombador de terra, conduzido por apenas um animal, seja ele uma mula ou um burro (Ibidem, 1984).

Este período econômico e de uso da terra foi o motor para as transformações brutais das paisagens do noroeste paulista, principalmente no que se refere à magnitude dos impactos da interferência humana no ambiente, ocasionado pela fragmentação das glebas, processos de desflorestamento, queimadas, agricultura intensiva e pastagens. A ruptura do equilíbrio ambiental em grande escala ocasionou os primeiros processos erosivos antrópicos, remanuseando em poucos anos boa parte dos sedimentos e eventuais materiais arqueológicos depositados nessas localidades (CHRISTOFOLETTI, 1980; MIGUEL, 2001).

\subsubsection{O Setor Sucroalcooleiro}

O contexto das áreas de expansão da lavoura de cana de açúcar no estado de São Paulo remete, em tempos mais próximos, ao Proálcool, implantado na década de 1970, e que foi o impulsionador do capital agroindustrial que expropriou populações tradicionais e estimulou a proletarização no campo. O êxodo rural gerou grande mobilidade geográfica de camponeses, remanescentes quilombolas, descendentes de imigrantes, grupos indígenas, entre outros produtores rurais, que foram submetidos a uma inserção precária na vida urbana, deixando para trás as áreas de cultivo, estas transformadas em grandes concentrações de terra e capital, sob o domínio de grupos/empresas (OLIVEIRA, 2009).

O estado de São Paulo é propício à expansão da atividade canavieira devido às suas condições ambientais adequadas ao desenvolvimento da cultura, solo apto à mecanização, logística e amplo mercado consumidor. No caso da região de São José do Rio Preto (engloba a B. H. Turvo-Grande), as pastagens estão sendo substituídas pelo cultivo da cana, desde a década de 1980, e com maior intensidade após o ano 2000, onde levantamento efetuado em 2009 registrou 623 mil hectares de cana plantada (Ibidem, 2009).

A territorialização sucroalcooleira atinge com rapidez grandes extensões de terras próprias e/ou consorciadas num sistema de produção agroexportador, cujo monocultivo está subordinado às unidades processadoras. Seu movimento constante de autoexpansão altera o processo produtivo, de trabalho e de regimento das vertentes (OLIVEIRA, 2009; CASSETI, 1991). 
A apropriação e transformação das vertentes pelo uso do solo agrícola, como as grandes extensões de lavoura de cana de açúcar, oferecem condições à intensificação dos processos exógenos, favorecendo a desagregação mecânica do solo pelas águas pluviais, principalmente nas épocas de fortes chuvas. Esse processo responde pelo aumento do fluxo de água por terra, ocasionando dessolagem, ravinamento, deslizamento de massa, ou seja, o componente erosivo paralelo, fruto do escoamento da água, passa a predominar sobre o perpendicular, ocasionado pela infiltração da água, implicando no desequilíbrio da vertente (CASSETI, 1991) e na reconfiguração do registro arqueológico ali contido.

Processos antrópicos como a lavoura afetam diretamente a retirada da cobertura vegetal, que por sua vez influencia em fatores processuais, como a hidrologia e o intemperismo que geram respostas nas formas erosivas e deposicionais de uma vertente. Como dito, o aumento do fluxo da água por terra gera o aumento do escoamento superficial e subsuperficial, ocasionando erosão laminar, erosão em sulcos ou calhas erosivas, que além de modificar as feições geomorfológicas de uma vertente, desprende e transporta possíveis vestígios arqueológicos de seu depósito de origem (RUBIN; SILVA, 2004).

Os diversos tipos de processos erosivos e feições erosivas, ocasionados pela ocupação antrópica, são agravados pelo avanço da agricultura mecanizada, com o uso do arado e subsolador implicando diretamente na dinâmica das vertentes, incidindo diretamente na dinâmica das vertentes, bem como nos depósitos arqueológicos e tamanho dos artefatos, (FACCIO, 2011). O uso de implementos agrícolas mecânicos vem acontecendo na área de interesse há pelo menos 30 anos (www.bunge.com.br). O arado e o subsolador têm por função romper a camada de solo que existe entre 40 e $50 \mathrm{~cm}$ de profundidade, promovendo o deslocamento de porções de solo e provocando, com suas hastes cortantes, deslocamentos verticais de terra (MORAIS, 1999).

Todo o registro arqueológico detectado, georreferenciado e escavado na B. H. do Turvo-Grande, foi incorporado à recente zona arada pertencente à vasta área cultivada. Isso significa que por longos períodos sazonais de cultivo, o registro arqueológico teve seu contexto deposicional misturado, comprometendo a distribuição de materiais arqueológicos em estratigrafia, redução do tamanho dos materiais e, consequentemente, crescimento da população de material arqueológico, formando novos conjuntos sobre a superfície e subsuperfície (ARAÚJO, 2002; DUNNEL; SIMEK, 1995; FACCIO, 2011).

O processo de ocupação humana das vertentes que as utilizam de modo intensivo, aliado ao desmatamento, monocultura, exposição do solo à erosão e o uso de suplementos 
agrícolas mecânicos, ocasiona uma severa perda do pacote sedimentar, que influencia na "espessura do horizonte do solo, onde estão inseridos os vestígios arqueológicos e na distribuição horizontal e vertical destes vestígios" (RUBIN; SILVA, 2004, p. 184). Dependendo do declive e forma da vertente, tipo de solo, regimento de chuvas, uma área de cultivo pode perder até 30 toneladas de terra por hectare durante um ano (CASSETI, 1991; RUBIN; SILVA, 2004).

\subsubsection{O Setor Energético (Hidroelétrico)}

A Bacia Hidrográfica do Rio Grande (BHRG) abrange um território com mais de 143 mil Km² de área de drenagem e compõe a Bacia do Prata. O Rio Grande nasce na Serra da Mantiqueira, município de Bocaina de Minas - MG, onde, a partir de sua cabeceira, escoa no sentido oeste, onde deságua no Rio Paraná. Em termos de capacidade instalada de geração de energia elétrica, a BHRG responde por $8 \%$ do potencial energético do País, que é distribuído entre treze barragens instaladas, das quais, a mais importante para nossos estudos é a de Marimbondo (www.grande.cbh.gov.br).

A UHE - Marimbondo, localizada entre as cidades de Icém (SP) e Fronteira (MG), teve suas obras iniciadas em 1971 e concluídas em 1975. Em 1977, todas as unidades da usina estavam conectadas ao sistema em amplo funcionamento. Seu reservatório de água apresenta uma área inundada de $438 \mathrm{~km}^{2}$ e possui um volume total de água de 6,150 bilhões $\mathrm{m}^{3}$ (www.furnas.com.br). Importante salientar que o Sítio Arqueológico Menino Jesus localiza-se na faixa de depleção do reservatório citado, onde ocorrem constantes processos morfogenéticos, ocasionados pelo transporte de sedimentos e oscilação do nível de base desse lago artificial (MIGUEL, 2001).

Estudos concernentes à análise de vestígios arqueológicos expostos às zonas de margem de flutuação dos reservatórios já foram realizados no Brasil (CHMYZ, 2004; COLAÇO, 2001; FACCIO, 1998; MIGUEL, 2001; KASHIMOTO, 1997; ROBRAHN GONZÁLEZ; DE BLASIS, 2010) e são fontes importantes para a avaliação das erosões fluvial, pluvial e eólica sobre o registro arqueológico.

Em nível de análise geral, o estudo do impacto dos reservatórios sobre o registro arqueológico concentra-se no "entendimento da disposição dos vestígios, sob a ótica da inserção destes materiais nos processos - produtos geodinâmicos formadores da morfologia atual da represa" (MIGUEL, 2001, p. 43). Nesse aspecto, a pluviosidade é um fator dos mais relevantes, pois condiciona a oscilação do nível da água do reservatório, 
que combinada à característica topográfica e a textura dos solos resulta no fator "condições de suscetibilidade à erosão" (Ibidem, 2001, p. 58). Fator este primordial aos processos pós-deposicionais de um sítio arqueológico.

A dinâmica hidrográfica da área onde se situa o reservatório de Marimbondo é controlada pelo sistema hidrelétrico que proporciona, em épocas de alta pluviosidade, o alargamento do canal principal e de seus afluentes, encobrindo o registro arqueológico e fontes importantes para ocupação humana em escala local, como as jazidas de argilas e nascentes. Quando as águas do reservatório avançam sobre as encostas da vertente, deposita-se considerável sedimento aluvial. Por sua vez, quando as águas se retraem, por conta de períodos de estiagem ou motivos operacionais, ocorre a erosão fluvial, devido ao solapamento de suas margens (COLAÇO, 2001; KASHIMOTO, 1997).

A conservação dos sítios arqueológicos inseridos em faixas de variações sazonais de nível de água, como os reservatórios artificiais, estão sujeitas ao processo de retalhamento das margens, ocasionados pelo recuo e avanço das águas, proporcionando o deslocamento dos vestígios arqueológicos, modificando a feição do depósito arqueológico e causando forte intemperismo no material arqueológico, por processo de decomposição química e física, entre outros processos (COLAÇO, 2001; MIGUEL, 1997; CHMYZ, 2004).

\subsection{Programa de Salvamento Arqueológico}

O Programa de Salvamento Arqueológico procurou aliar o levantamento superficial com as intervenções subsuperficiais nos compartimentos ambientais da área dos sítios arqueológicos e de seu entorno. Os procedimentos de campo foram realizados em conformidade com a natureza do terreno, que tem como características primordiais estar em propriedades poligonais, atravessar áreas rurais, superfícies predominantemente permeáveis e diversos compartimentos topográficos.

O desenvolvimento das intervenções de campo foi realizado a partir de mecanismo de multiestágios, inicialmente, no reconhecimento geral da área, reunindo dados essenciais a respeito dos compartimentos ambientais significativos ao assentamento arqueológico, além das observações acerca do ambiente físico-biótico e antropizado da paisagem (MORAIS, 1999; REDMAN; WATSON, 1970).

Nessa etapa houve, concomitantemente, o detalhamento da área do sítio arqueológico por meio de caminhamentos sistemáticos, intervenções subsuperficiais com 
profundidades médias de $60 \mathrm{~cm}$, havendo variações em sua profundidade de acordo com as características topográficas, pedológicas e do grau de antropização do terreno. Assim, procurou-se detalhar as características pedológicas do terreno, bem como detectar possíveis distribuições de vestígios arqueológicos em superfície e subsuperfície (FACCIO, 1998; MORAIS, 2006).

O objetivo geral do Programa de Salvamento foi a detecção de vestígios arqueológicos por meio de um modelo relacionado à amostragem por levantamento sistemático de superfície, execução de poços-teste e métodos de escavação como abertura de trincheira e decapagem em níveis estratigráficos artificiais. A configuração do trajeto realizado pelo pesquisador considerou características do terreno como a cobertura vegetal, áreas de lavoura e acessos, que somados à densidade de artefatos arqueológicos determinaram as inferências e interpretações a respeito das ocupações humanas pretéritas (ARAUJO, 2001; CALDARELLI, 2007).

Dessa forma, a intensidade da intervenção arqueológica e a configuração geométrica da área dos sítios arqueológicos foram ponderadas neste trabalho. Por intensidade entendemos os pontos e linhas de observação e coleta, bem como a quantidade de sondagens e escavações executadas no terreno. Neste projeto cada sítio foi considerado um polígono pelo qual foram traçados linhas de caminhamento paralelos onde as diversas equipes realizaram o caminhamento sistemático e a confecção de poçosteste. Em geral a distância das linhas de caminhamento e prospecção foi igual ou próxima a dois metros. Variações ocorreram devido à configuração natural do terreno ou do uso e ocupação do solo (ARAÚJO, 2001).

A intensidade da realização dos poços-teste, trincheira e decapagem relacionouse com o tamanho da área do sítio e dos resultados obtidos na etapa de caminhamento sistemático. O intuito foi realizar um corte no terreno que permitisse o exame e a descrição dos solos em seu ambiente, demonstrando a sucessão de horizontes pedogenéticos e antrópicos contidos nessa seção vertical (MORAIS, no prelo). A descrição desses horizontes pedogenéticos se pautou na sucessão de seu perfil, sentido superfície às camadas mais subsuperficiais, descrevendo os materiais (orgânicos, geológicos ou antrópicos) encontrados, a cor do sedimento, sua textura e compactação.

As intervenções de campo realizadas estiveram em consonância com a agenda do empreendimento sucroalcooleiro. No momento em que os talhões onde estão inseridos os sítios arqueológicos receberam o corte da cana e a preparação da terra para novo cultivo, a equipe de arqueologia foi prontamente solicitada para a realização da etapa de 
salvamento arqueológico. Assim, a alta visibilidade de solo, como as áreas aradas, ruas entre os plantios, carreadores e solo exposto, facilitou o trabalho de identificação ou refutação da presença de materiais arqueológicos em diversos locais.

A metodologia de trabalho para essa etapa foi adaptada das pesquisas de Araújo (1999, 2001) e Dunnell e Simek (1995) estabelecendo a realização de coletas múltiplas de superfície em um mesmo sítio para que se possa caracterizar as distribuições espaciais dos materiais arqueológicos com maior precisão. Essas coletas foram realizadas em condições sazonais semelhantes, todas ocorrendo no mês de Setembro dos anos de 2011, 2013 e 2014, quando da recém-aragem do terreno para o plantio.

\subsubsection{Resgate arqueológico e resultados da pesquisa}

O presente trabalho abordou, sob a ótica da arqueologia da paisagem, parte da região Norte do estado de São Paulo. Os sítios arqueológicos estudados localizam-se na Bacia Hidrográfica do Rio Turvo-Grande, dentro dos Municípios de Orindiúva, Paulo de Faria e Icém (FACCIO et. al., 2012). Nesse contex to geográfico propomos o estudo de quatro sítios arqueológicos pré-coloniais: Barra de Ouro, Porto Velho, Porto Velho II e Menino Jesus e um sítio histórico: Santa Filomena (FACCIO et. al., 2012).

Nesta tese entendemos sítio arqueológico como a menor unidade do espaço passível de investigação, dotada de objetos intencionalmente produzidos ou rearranjados, que testemunham comportamentos das sociedades do passado (MORAIS, 2006, p.207). Para Butzer (2006) sítio arqueológico pode ser definido como registro tangível de um lócus de atividade humana. Os sítios podem variar em escala a partir de um local de atividade simples até um assentamento urbano complexo. Fica claro nas duas definições que os sítios arqueológicos são registros materiais que expressam comportamentos pretéritos em diferentes escalas espaciais, temporais e comportamentais. Para área de ocorrência entendemos como "objeto único ou quantidade ínfima de objetos aparentemente isolados ou desconexos encontrados em um determinado local" (MORAIS, 2006, p. 207).

No ano de 2009 foi realizado levantamento prospectivo nesses sítios e áreas de ocorrências arqueológicas. Em síntese, os sítios arqueológicos localizaram-se nos compartimentos topomorfológicos de média e baixa vertente, geralmente em locais utilizados para o plantio de cana-de-açúcar, como carreadores, área de preservação permanente e faixa de depleção (FACCIO et. al., 2012). 
Os objetos arqueológicos manufaturados constituíram-se de lascas iniciais em matéria-prima de arenito silicificado, quartzo e silexito, percutor sobre seixo, lâmina de machado polida em basalto, além de fragmentos de recipientes cerâmicos. Os fragmentos cerâmicos se apresentaram, predominantemente, como fragmentos de paredes, bordas e bases com tratamento de superfície alisado e fragmentos de bordas com incisões paralelas às bordas.

Nos anos de 2013 e 2014 foram realizadas as seguintes etapas: reavaliação dos sítios arqueológicos, monitoria nas áreas de depleção, mapeamento de flora nativa, mapeamento de geoindicadores (nascentes, fontes de argila e cascalheiras), coleta de argila para testes arqueométricos e resgate arqueológico.

Nesse contexto de pesquisa foram coletados objetos arqueológicos que foram analisados em laboratório ${ }^{68}$. Essa análise, a exemplo dos fragmentos cerâmicos, resumese ao registro, classificação e cruzamento dos atributos tecnomorfológicos e estilísticos. O foco central dessas análises incidiu sobre a confecção da pasta, a inserção do engobo, os fragmentos que apresentaram pintura ou incisão em sua superfície. A reconstituição das formas dos vasos cerâmicos nos possibilitou construir um quadro morfológico que pode ser usado para inferir uso e tamanho dos grupos que os confeccionaram.

\subsubsection{O sítio arqueológico Barra de Ouro}

\subsubsection{O trabalho de campo}

No ano de 2009, durante a etapa de Prospecção Arqueológica, o Sítio Arqueológico Barra de Ouro foi identificado na vertente do Córrego da Mandioca, próximo à vertente do Rio Grande, sendo localizados e coletados dentro de seu perímetro fragmentos cerâmicos, lítico polido e líticos lascados. Salientou-se, na época, que esse conjunto de artefatos arqueológicos sofreu forte intervenção antrópica, por estar estabelecido em área de plantio antigo de cana-de-açúcar, onde o arado, o subsolador e os processos erosivos do solo são permanentes (FACCIO, 2009). A Figura 18 mostra o polígono que delimita a área do Sítio Arqueológico Barra de Ouro.

$\mathrm{Na}$ época, foi considerado que, apesar de os cortes de verificação não terem apresentado material arqueológico, na etapa seguinte, a do resgate arqueológico, se

\footnotetext{
${ }^{68}$ Laboratório de Arqueologia Guarani (FCT - UNESP), coordenado pela Profa. Neide Barrocá Faccio.
} 
efetuasse a limpeza da vegetação, coleta de superfície, acompanhamento sistemático da aragem da terra em épocas de plantio e abertura de trincheira para verificação do subsolo (FACCIO, 2009).

Figura 18 - Localização do Sítio Barra de Ouro

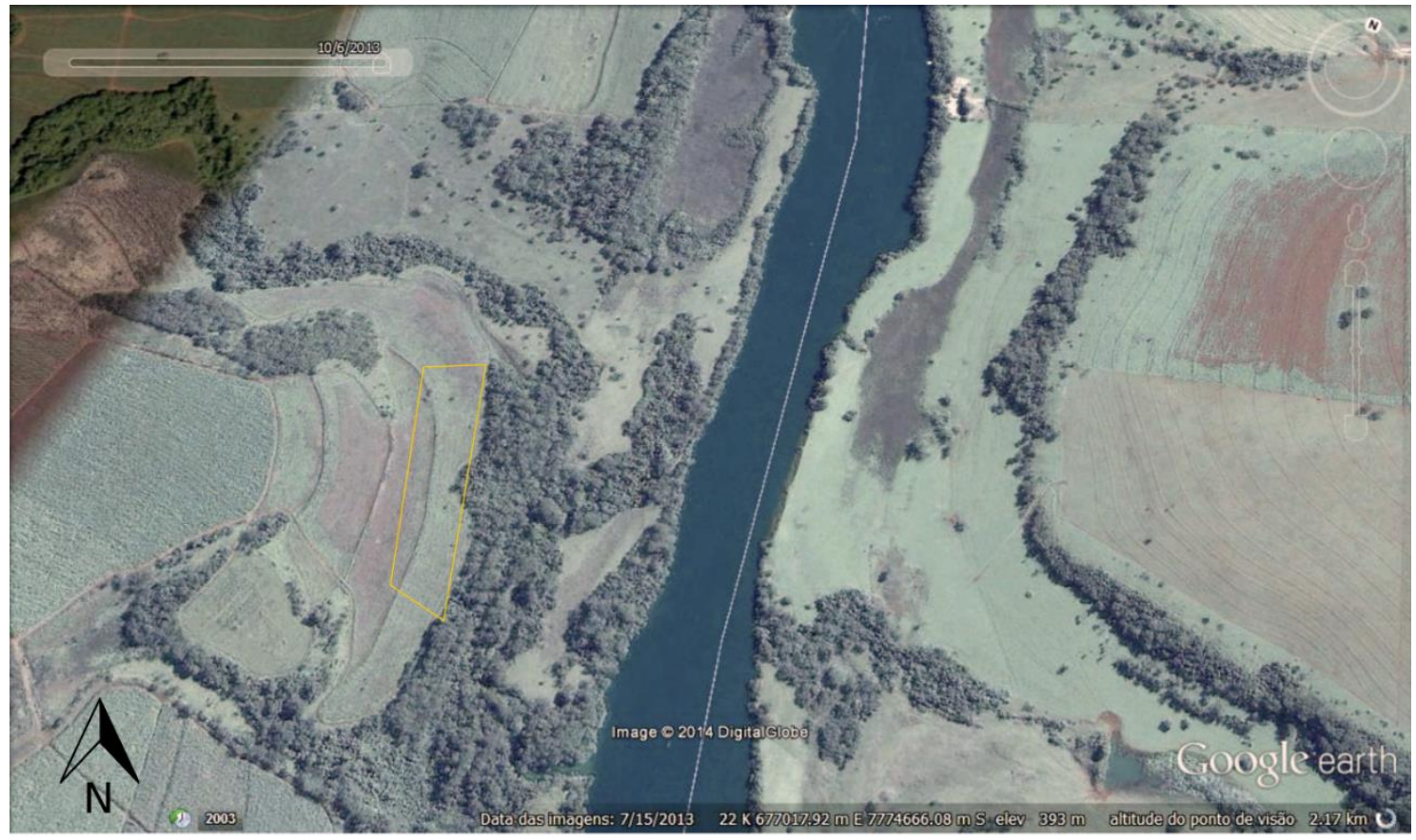

Legenda:

Área do Sítio Barra de Ouro

\section{Escala gráfica aproximada}

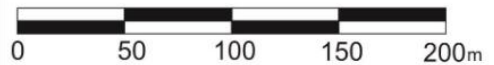

Fonte: Google Earth e Faccio (2009; 2015).

Nos anos de 2011, 2013 e 2014 a equipe de arqueologia realizou a etapa de resgate arqueológico do Sítio Barra de Ouro. Em diversas etapas de trabalho foram realizadas caminhadas sistemáticas de superfície e acompanhamento das áreas recém-aradas que abarcaram parte do sítio. Esses procedimentos objetivaram identificar concentrações e dispersões de materiais arqueológicos, bem como nortear futuras ações e intervenções.

Em suma, as coletas de superfície iniciais foram realizadas durante o ano de 2009, sendo identificados e mapeados 44 pontos. O primeiro acompanhamento do setor agrícola recém-arado ocorreu em Setembro de 2011, sendo identificados 17 pontos de coleta. O segundo acompanhamento aconteceu em Setembro de 2013, identificando quatro pontos, e o terceiro acompanhamento ocorreu em Setembro de 2014, identificando três pontos. O cruzamento dos dados de coletas plotados em mapa permitiu identificar uma área de 
maior concentração de material arqueológico, optando-se, nesse local, realizar uma trincheira de verificação. A trincheira foi confeccionada com $1 \mathrm{~m}$ de largura por $15 \mathrm{~m}$ de comprimento. A proposta foi rastrear possíveis vestígios arqueológicos em subsuperfície e delimitar um perfil estratigráfico do pacote sedimentar local.

O pacote sedimentar apresentado é pouco profundo, atingindo sua base rochosa em média nos $60 \mathrm{~cm}$ de profundidade, apresentando abundância de matéria-prima em quartzo (blocos de quartzo) em profundidade. Quanto à identificação de material arqueológico, coletou-se duas lascas, indicando que o procedimento anterior havia realizado a maior parte da identificação do material naquele local. Com o término da escavação da trincheira o resgate arqueológico nesse sítio se deu por encerrado.

Diante dos resultados do trabalho de campo concluiu-se que se trata de um sítio com distribuição dos vestígios arqueológicos em uma dimensão aproximada de 615 metros de comprimento, na direção NS, por 175 metros de largura na direção LO, com pequena quantidade de materiais arqueológicos. O Sítio Arqueológico Barra de Ouro apresentou em sua coleção: dois fragmentos de cerâmica, 68 líticos lascados e um lítico polido (Figura 19)

\subsubsection{Quadro geoambiental e pós-deposicional}

Unidade de Vertente: Declive Coluvial;

Elevação Topográfica: 393 metros;

Corpos de Água: Distante 50 metros do Córrego da Mandioca e 120 metros do Rio Grande;

Descrição Geomorfológica: Entre Planícies Baixas, próximo as margens dos rios, e Colinas Amplas, com topos extensos e aplainados e vertentes com perfis retilíneos e convexos;

Efeito Climático Local: Meses de Junho, Julho e Agosto com menor precipitação (mínima de 16,1mm) e meses de dezembro e janeiro como os mais chuvosos (máxima de $278,2 \mathrm{~mm})$

Substrato Geológico/Pedológico: Inserido na Formação Serra Geral, apresentou pacote sedimentar pouco profundo (média-baixa vertente) com média de $60 \mathrm{~cm}$ de profundidade, classe Latossolo Vermelho, matiz 2,5YR, com presença de blocos de quartzo e substrato rochoso de basalto pouco consolidado; 
Uso e Ocupação do Solo: Lavoura de Cana-de-açúcar, onde se realizam atividades como o preparo do solo, cultivo e tratos culturais;

Intemperismo e Bioturbação: Decomposição das rochas básicas por meio da percolação de água e sua saturação no horizonte C (material inconsolidado de rocha alterada). Enraizamento das rochas e de possíveis materiais arqueológicos em subsuperfície. Com o tombamento de árvores esses materiais ficaram agregados as raízes das árvores.

Atividades Antrópicas: Preparo do solo implicando subsolagem, gradagem pesada (grades de 20 discos com diâmetros de 30 a 32cm), aração com aveica (inversão de uma camada de 40 a $45 \mathrm{~cm}$ de espessura) e construção de carreadores.

Processos Erosivos/Deposicionais: Ocorre na unidade declive coluvial forte perturbação da superfície e subsuperfície pela retirada da vegetação e atividades agrícolas, provocando durante a época de chuvas, erosão linear com fluxo concentrado de água, confeccionando sulcos nas áreas de carreadores e nos caminhos que levam aos cursos de água. Na área de plantio não foi possível identificar feições erosivas devido as recém aragens efetuadas no local. Observou-se material sedimentar coluvial deslocados pelo escoamento pluvial em direção ao Córrego da Mandioca e pequeno tributário, provocando assoreamento nesses locais;

Vegetação remanescente: Angico (Anadenanthera spp); Figueira (Ficus Citrifolia); Jatobá (Hymenaea Courbaril); Embaúba (Cecropia Pachystachia); Monjoleiro (Senegalia Plyphylla); Macaúba (Acrocomia Aculeata); Bacuri (Attalea Phalerata);

Áreas de Captação de Matéria Prima: Notou-se tanto no declive coluvial, quanto no fundo de vale, a presença de cristais e blocos de quartzo e silexito em superfície. Próximo aos cursos de água foram identificados seixos de quartzo, quartzito e arenito silicificado. Essa matéria prima disponível no entorno imediato do sítio foi provavelmente utilizada para a fabricação de lascas e instrumentos. Fontes de argila foram detectadas em depósito aluvial oriundo de pequeno tributário do Córrego da Mandioca;

Processos pós-deposicionais atuantes sobre o registro arqueológico: Pôde-se notar acúmulo de materiais arqueológicos nas áreas de carreadores e redes erosivas formadas na baixa vertente. A descida de materiais arqueológicos ocorreu devido ao escoamento pluvial que transportou os materiais arqueológicos expostos em superfície e nas camadas menos espessas dos solos arados.

Por outro lado, atividades antrópicas como subsolagem, gradagem e aragem provocaram severos deslocamentos verticais dos vestígios arqueológicos e redução dos mesmos. 
Figura 19 - Dispersão dos materiais arqueológicos do Sítio Barra de Ouro

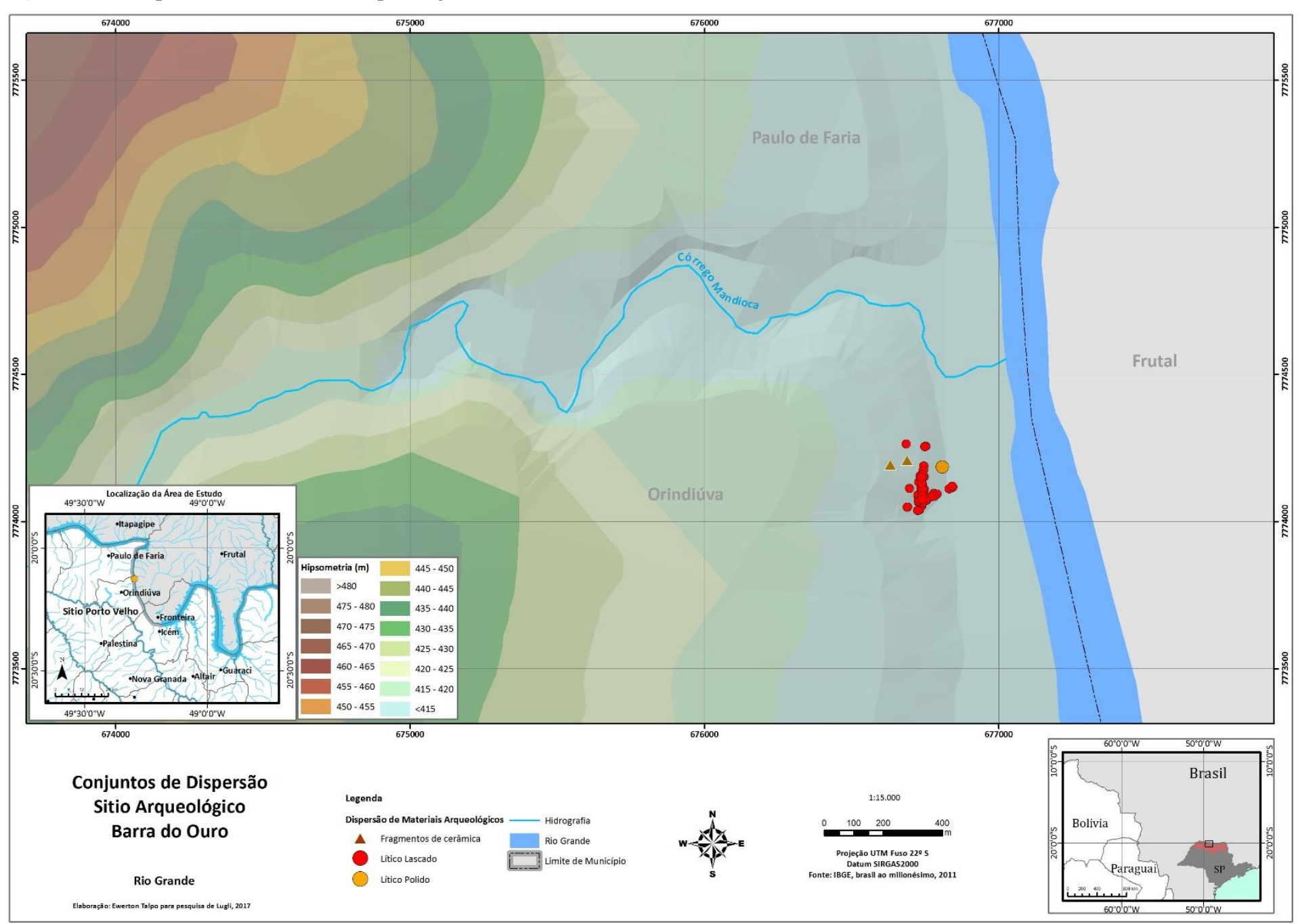

Fonte: IBGE. Confecção: Ewerton Talpo e David Pereira. 


\subsubsection{Análise da coleção arqueológica}

Os líticos lascados

Nessa indústria lítica foram identificados atributos relacionados à classificação dos materiais por categoria, matéria-prima, suporte e também por características referentes à sua produção tecnológica como, por exemplo, tipos de talão, morfologia das lascas, dimensões das peças entre outros atributos. A coleção lítica lascada do Sítio Barra de Ouro é composta por um total de 68 peças. Em relação aos líticos polidos, identificouse apenas um exemplar.

No que diz respeito às matérias-primas identificadas e contabilizadas para a esta coleção, notamos a maior frequência do arenito silicificado, em 29,4\% dos casos, e do silexito, em 26,4\% dos casos, seguidos pelo quartzo, em 20,4\% dos casos. Sabemos que a região geográfica dos sítios estudados apresenta afloramentos desses três tipos de materiais, sendo que todos apresentam potencial para o trabalho do lascamento. Há também o afloramento da matéria-prima basalto, que neste caso, tem maior aptidão para a confecção de materiais polidos. Foi possível identificar também, matérias-primas com sinais de trabalho de lascamento em quartzito, argilito ou siltito e também em materiais onde houve a intrusão de duas matérias-primas, como foi o caso do silexito e quartzo (Tabela 1).

Tabela 1 - Frequência de matérias-primas identificadas no Sítio Barra de Ouro. Paulo de Faria, SP.

\begin{tabular}{ccc}
\hline Matérias-primas & Quantidade de peças & $\mathbf{\%}$ \\
\hline Arenito Silicificado & 20 & $29,4 \%$ \\
\hline Quartzito & 07 & $10,2 \%$ \\
\hline Quartzo & 14 & $20,4 \%$ \\
\hline Silexito & 18 & $26,4 \%$ \\
\hline Silexito/Quartzo & 06 & $8,8 \%$ \\
\hline Siltito & 02 & $2,9 \%$ \\
\hline Siltito/Silexito/Quartzo & 1 & $1,4 \%$ \\
\hline Total & $\mathbf{6 8}$ & $\mathbf{1 0 0}$
\end{tabular}


Com relação às categorias de materiais identificados e classificados para o Sítio Barra de Ouro, a maior frequência apresentada foi a categoria lasca, com 55,8\% dos casos. Também foi identificada a presença de materiais em estado bruto, como foi o caso dos seixos, com 13,2\% dos casos. (Tabela 2).

Tabela 2 - Categorias de materiais classificados para o Sítio Barra de Ouro, Paulo de Faria, SP.

\begin{tabular}{ccc}
\hline Categorias & Quantidade de peças & $\mathbf{\%}$ \\
\hline Lasca & 38 & $55,8 \%$ \\
\hline Lasca Fragmentada & 03 & $4,4 \%$ \\
\hline Fragmento de Lasca & 03 & $4,4 \%$ \\
\hline Instrumento & 01 & $1,4 \%$ \\
\hline Fragmento de & 01 & $1,4 \%$ \\
\hline Instrumento & 01 & $1,4 \%$ \\
\hline Instrumento Fragmentado & 05 & $7,3 \%$ \\
\hline Núcleo & 04 & $5,8 \%$ \\
\hline Resíduo & 09 & $13,2 \%$ \\
\hline Seixo & 02 & $2,9 \%$ \\
\hline Seixo Fragmentado & 01 & $1,4 \%$ \\
\hline Fragmento de Bloco & $\mathbf{6 8}$ & $\mathbf{1 0 0}$ \\
\hline Total & Fonte: Faccio, 2015 &
\end{tabular}

A Tabela 3 apresenta a frequência dos suportes da coleção lítica do Sítio Barra de Ouro. O suporte mais utilizado foi o seixo, com $35,2 \%$ dos casos, seguido pelo bloco, com $11,7 \%$ dos casos, e do cristal, com $8,8 \%$ dos casos. Na maior parte dos materiais, em $36,7 \%$ dos casos, não foi possível identificar o suporte.

Esta informação permite interpretar elementos relacionados à disposição de materiais e seus estados físicos na natureza e os critérios de escolha dos suportes para o seu uso no trabalho de lascamento.

$\mathrm{Na}$ análise de laboratório, notou-se a associação dos suportes em seixo com a matéria-prima quartzo/quartzito, em 11 casos, e em arenito silicificado, em 5 casos. No suporte em bloco a matéria-prima predominante foi o silexito, em 4 casos. Esta relação poderá auxiliar na compreensão dos procedimentos de escolha de cada matéria-prima em suas associações com os estados físicos dos suportes presentes na natureza. 
Tabela 3 - Frequência de suportes identificados no Sítio Barra de Ouro, Paulo de Faria, SP.

\begin{tabular}{ccc}
\hline Suportes & Quantidade de peças & \% \\
\hline Seixo & 24 & $35,2 \%$ \\
\hline Nódulo & 05 & $7,3 \%$ \\
\hline Bloco & 08 & $11,7 \%$ \\
\hline Cristal & 06 & $8,8 \%$ \\
\hline Não Identificado & 25 & $36,7 \%$ \\
\hline Total & $\mathbf{6 8}$ & $\mathbf{1 0 0}$ \\
\hline
\end{tabular}

O lítico polido

Nesse sítio foi encontrada uma lâmina de machado em basalto durante a etapa de prospecção arqueológica (Foto 1).

Foto 1 - Lítico Polido do Sítio Arqueológico Barra de Ouro.

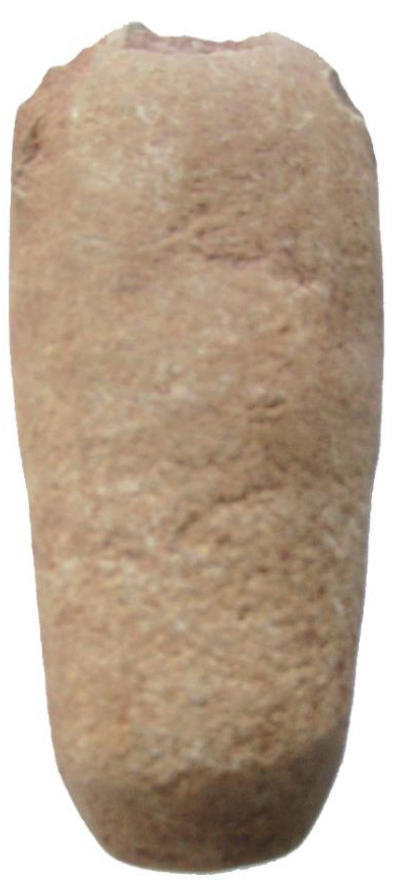

Fonte: Faccio, 2015 
O material cerâmico do Sítio Arqueológico Barra de Ouro é proveniente de coleta de superfície e de cortes de verificação, realizados no momento da prospecção. Pelo fato do Sítio Barra de Ouro não ter apresentado vasilhas cerâmicas inteiras, o primeiro encaminhamento proposto para a análise do material foi o de agrupar os fragmentos de um mesmo vaso em conjuntos. Esse encaminhamento mostrou a ausência de conjuntos. Dessa forma, trabalhou-se com os fragmentos individualmente.

A Tabela 4 mostra as classes de peças evidenciadas no Sítio Arqueológico Barra de Ouro.

Tabela 4 - Classe de Peças Cerâmicas identificados no Sítio Barra de Ouro, Paulo de Faria, SP.

\begin{tabular}{l|l}
\hline Classe & Quantidade de Peças \\
\hline Parede & 10 \\
\hline Borda & 1 \\
\hline Total & $\mathbf{1 1}$ \\
\hline \multicolumn{2}{r}{ Fonte: Faccio, 2015 }
\end{tabular}

Foram identificadas apenas as classes parede e borda, totalizando 11 fragmentos.

O sítio apresentou, em todos os fragmentos, cerâmica lisa. Na relação estabelecida entre o uso barbotina ${ }^{69}$ e o tipo de pasta, predominou a não utilização da barbotina nos três tipos de pasta: plástica, intermediária e dura (indicadas pela quantidade de antiplástico misturado à argila no fabrico das peças).

No Sítio Barra de Ouro foram encontrados materiais líticos lascados, poucos fragmentos de cerâmica e uma lâmina de machado. Pelo fato do sítio não possuir estratigrafia devido ao uso do arado e do subsolador não foi possível saber se esses vestígios são provenientes de uma ou mais ocupações indígenas.

\subsubsection{O Sítio Arqueológico Porto Velho I}

\subsubsection{O Trabalho de campo}

\footnotetext{
${ }^{69}$ Barbotina é um revestimento superficial de argila mais refinada, aplicado à cerâmica antes da queima. Os acabamentos superficiais, por vezes, exigem uma aplicação diversa daquela que a produziu, aguardando uma arte final decorativa: plástica ou pintura. (La Salvia e Brochado, p. 17, 1989)
} 
No ano de 2009, durante a etapa de Prospecção Arqueológica, o Sítio Arqueológico Porto Velho I foi identificado na vertente do Rio Grande, a aproximadamente 100 metros de sua margem. Na época, a maior parte do material arqueológico foi coletado superficialmente na Área de Proteção Permanente (APP), adentrando cerca de 10 metros no plantio de cana-de-açúcar. Foram localizados e coletados dentro de seu perímetro fragmentos de cerâmica, sendo identificadas as classes parede e borda. Das duas bordas identificadas, em nenhum caso foi possível a reconstituição da forma do vaso (FACCIO, 2009). A Figura 20 mostra o polígono que delimita a área do Sítio Porto Velho I.

$\mathrm{Na}$ época, constatou-se que os cortes de verificação não apresentaram material arqueológico em subsuperfície. Para a etapa seguinte, a do resgate arqueológico, foram propostos: limpeza da vegetação rasteira nas áreas de APP., coleta de superfície, acompanhamento sistemático da aragem da terra em épocas de plantio e abertura de poços-teste para verificação do subsolo (FACCIO, 2009).

Figura 20 - Localização do Sítio Porto Velho I.

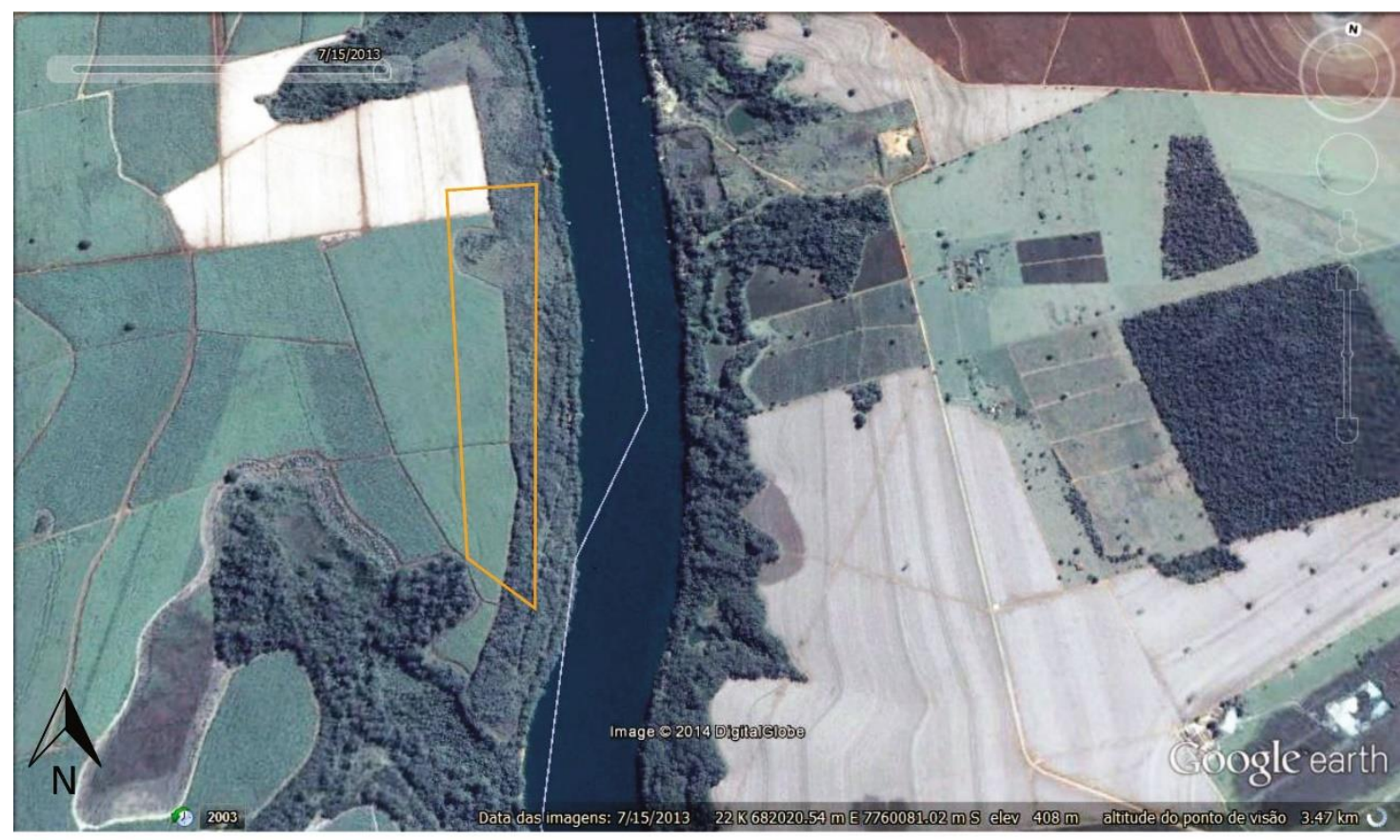

Legenda Área do Sítio Porto Velho

\section{Escala gráfica aproximada}

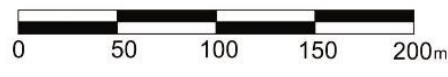

Fonte: Google Earth e Faccio (2009; 2015). 
No ano de 2013 e 2014 a equipe de arqueologia realizou a etapa de resgate arqueológico do Sítio Porto Velho I. Em diversas etapas de trabalho foram realizadas caminhadas sistemáticas de superfície, acompanhamento dos setores de aragens que abarcaram parte do sítio, limpeza da vegetação rasteira nas áreas de proteção permanente e execução de poços testes. Esses procedimentos objetivaram identificar concentrações e dispersões de materiais arqueológicos.

Durante as coletas de superfície iniciais foram identificados e mapeados 26 pontos. O primeiro acompanhamento de setor agrícola recém-arado ocorreu em Setembro de 2011, sendo identificado 6 pontos de coleta. O segundo acompanhamento aconteceu em Setembro de 2013 e não foi detectado material arqueológico.

O parco material coletado nessas etapas de caminhamentos sistemáticos indicava que, possivelmente, tratava-se de uma área de dispersão periférica de materiais arqueológicos. Naquele momento, acreditávamos que a "área nuclear" da ocupação pretérita poderia localizar-se na APP. Como se trata de uma área de preservação ambiental, as intervenções arqueológicas não puderam impactar a população biótica ali instalada. Para essa área adotou-se a técnica de pequenas intervenções (poços de sondagem) com o objetivo de identificar e mapear possíveis vestígios arqueológicos.

Nesta etapa foi selecionada uma área de 50mx50m objetivando realizar as sondagens subsuperficiais. A seleção da área obedeceu aos seguintes critérios: (1) adjacência com o carreador e a área de lavoura onde foram identificados e coletados objetos arqueológicos em etapas anteriores (2009, 2011 e 2013); (2) área de baixa visibilidade que, em etapas anteriores, haviam sido identificados e coletados objetos arqueológicos, mas que, no entanto, deveria receber novas intervenções.

Espécies nativas em estágio de reflorestamento foram cuidadosamente evitadas, para que não fosse gerado nenhum impacto à área de preservação. A limpeza ocorreu em áreas lineares de 50 metros que se entrecruzaram, formando uma única cruz, no sentido Leste-Oeste e Norte-Sul. Após a limpeza dessa área, foram realizadas inspeções superficiais para possíveis detecções de objetos ou vestígios arqueológicos. Nessa etapa nenhum ponto de coleta foi registrado. Após a inspeção, optou-se por confeccionar prospecções subsuperficias com a ferramenta escavadeira manual do tipo "boca de lobo" em profundidade de $60 \mathrm{~cm}$. A distância entre cada sondagem permaneceu em 10 metros. Assim, em forma de cruz foram confeccionadas nove sondagens subsuperficiais. Todo sedimento retirado das sondagens foi peneirado a cada 10 centímetros. Os resultados das sondagens subsuperficiais revelaram a ausência de objetos ou indícios arqueológicos. 
Diante dos resultados do trabalho de campo concluiu-se que se trata de um sítio com distribuição dos vestígios arqueológicos em uma dimensão aproximada de 1330 metros de comprimento, na direção NS, por 255 metros de largura na direção LO, com pequena quantidade de materiais arqueológicos. O Sítio Arqueológico Porto Velho I apresentou em sua coleção: 39 fragmentos de cerâmica, um lítico lascado e um lítico polido (Figura 21)

\subsubsection{Quadro geoambiental e pós-deposicional}

Unidade de Vertente: Declive Coluvial

Elevação Topográfica: 408 metros;

Corpos de Água: Distante 50 metros do Rio Grande;

Descrição Geomorfológica: Entre Planícies Baixas, próximo a margem de rio, Colinas Amplas, com topos extensos e aplainados e vertentes com perfis retilíneos e convexos;

Efeito Climático Local: Meses de Junho, Julho e Agosto com menor precipitação (mínima de 16,1mm) e meses de dezembro e janeiro como os mais chuvosos (máxima de $278,2 \mathrm{~mm})$

Substrato Geológico/Pedológico: Inserido na Formação Serra Geral, apresentou pacote sedimentar profundo (média-baixa vertente) sendo prospectado subsuperficialmente $80 \mathrm{~cm}$ de profundidade sem que se pudesse detectar o embasamento rochoso, classe Latossolo Vermelho, matiz 2,5YR, com afloramento de blocos de rochas básicas próximo ao talvegue do Rio Grande;

Uso e Ocupação do Solo: Lavoura de Cana-de-açúcar, onde se realizam atividades como o preparo do solo, cultivo e tratos culturais;

Intemperismo e Bioturbação: Decomposição das rochas básicas próximas ao talvegue do Rio Grande por meio da meteorização química e bioquímica.

Atividades Antrópicas: Preparo do solo implicando subsolagem, gradagem pesada (grades de 20 discos com diâmetros de 30 a 32cm), aração com aveica (inversão de uma camada de 40 a $45 \mathrm{~cm}$ de espessura) e construção de carreadores;

Processos Erosivos/Deposicionais: Ocorre na unidade declive coluvial forte perturbação da superfície e subsuperfície pela retirada da vegetação e atividades agrícolas, provocando durante a época de chuvas, erosão linear com fluxo concentrado de água, confeccionando sulcos nas áreas de carreadores e nos caminhos que levam aos cursos de 
água. Na área de plantio não foi possível identificar feições erosivas devido as recém aragens efetuadas no local;

Vegetação Remanescente: Angico (Anadenanthera spp); Figueira (Ficus Citrifolia); Jatobá (Hymenaea Courbaril); Embaúba (Cecropia Pachystachia); Monjoleiro (Senegalia Plyphylla); Macaúba (Acrocomia Aculeata); Bacuri (Attalea Phalerata);

Áreas de Captação de Matéria-Prima: Notou-se nas áreas adjacentes aos carreadores seixos de matéria prima diversificada. No entanto, sabe-se que essa matéria prima foi transportada de outra região para pavimentar as áreas mais degradadas desses caminhos. Segundo os trabalhadores esses seixos foram coletados do Rio Grande. Nas proximidades não foi detectada fontes de argila que pudessem ter sido usadas para confecção de recipientes cerâmicos;

Processos pós-deposicionais atuantes sobre o registro arqueológico: Pôde-se notar acúmulo de materiais arqueológicos nas áreas de carreadores e redes erosivas formadas na baixa vertente. A descida de materiais arqueológicos ocorreu devido ao escoamento pluvial que transportou os materiais arqueológicos expostos em superfície e nas camadas menos espessas dos solos arados. Por outro lado, atividades antrópicas como subsolagem, gradagem e aragem provocaram severos deslocamentos verticais dos vestígios arqueológicos e redução dos mesmos. 
Figura 21 - Dispersão dos materiais arqueológicos do Sítio Porto Velho I

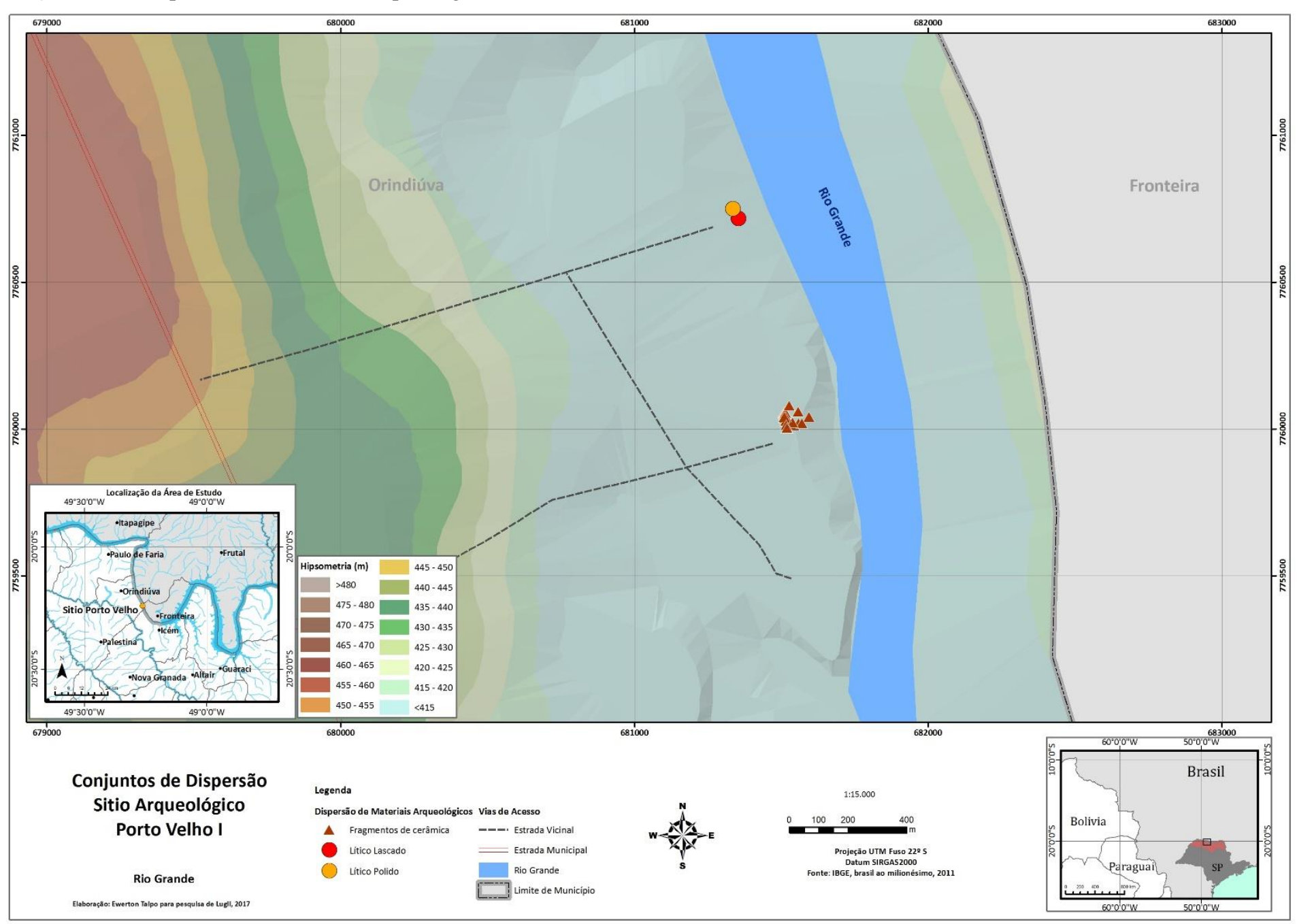

Fonte: IBGE. Confecção: Ewerton Talpo e David Pereira. 


\subsubsection{Análise da coleção arqueológica}

O lítico lascado

O Sítio Arqueológico Porto Velho I apresentou uma lasca de arenito silicificado (Foto 2).

Foto 2 - Lasca de arenito silicificado coletada no Sítio Arqueológico Porto Velho I.

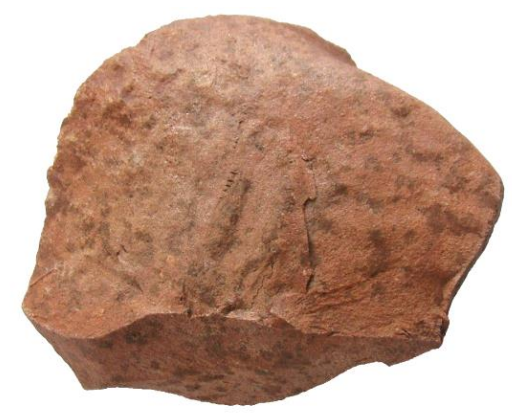

Fonte: Faccio, 2015

\section{O lítico polido}

O Sítio Porto Velho I apresentou um fragmento de pedra polida, provavelmente de uma mão de pilão (Foto 3).

Foto 3 - Fragmento de Pedra Polida coletado no Sítio Porto Velho I.

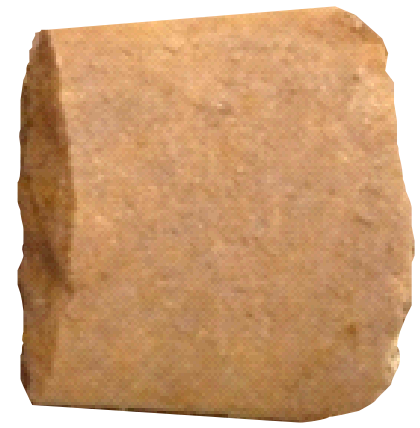

Fonte: Faccio, 2015

Os fragmentos de cerâmica

O material cerâmico do Sítio Arqueológico Porto Velho I é proveniente de coleta de superfície e de cortes de verificação, realizados no momento da prospecção. Pelo fato do Sítio Porto Velho I não ter apresentado vasilhas cerâmicas inteiras, o primeiro 
encaminhamento proposto para a análise do material foi o de agrupar os fragmentos de um mesmo vaso em conjuntos. Esse encaminhamento mostrou a ausência de conjuntos. Dessa forma, trabalhou-se com os fragmentos individualmente.

A Tabela 5 mostra as classes de peças evidenciadas no Sítio Arqueológico Porto Velho I.

Tabela 5 - Classe de Peças Cerâmicas identificados no Sítio Porto Velho I, Orindiúva, SP.

\begin{tabular}{l|l}
\hline Classe & Quantidade de Peças \\
\hline Parede & 29 \\
\hline Borda & 2 \\
\hline Total & $\mathbf{3 1}$ \\
\hline \multicolumn{2}{r}{ Fonte: Faccio, 2015 }
\end{tabular}

Foram identificadas apenas as classes parede e borda, totalizando 31 fragmentos. Foram identificadas 2 bordas, mas em nenhum caso foi possível a reconstituição da forma do vaso. A Foto 4 apresenta um fragmento de borda, provavelmente, pertencente a um vaso conjugado e com engobo preto em ambas faces.

Foto 4 - Fragmento de borda, provavelmente, pertencente a um vaso conjugado. Sítio Porto Velho I.

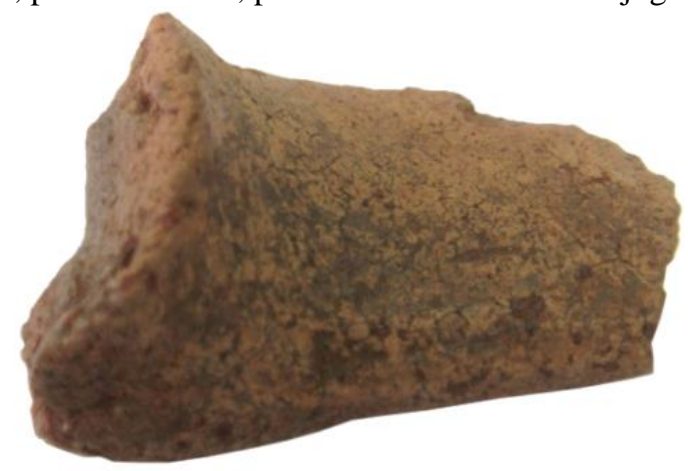

Fonte: Faccio, 2015

Na relação estabelecida entre o uso de barbotina e o tipo de pasta, predominou a não utilização da barbotina em três tipos de pasta: plástica, intermediária e dura (indicadas pela quantidade de antiplástico misturado à argila no fabrico das peças). Associado ao uso da pasta plástica ocorreu um fragmento com uso da barbotina na face externa e interna. Associado ao uso da pasta dura ocorreu um fragmento com uso da barbotina na face externa e interna. 


\subsubsection{O Sítio Arqueológico Porto Velho II}

\subsubsection{O Trabalho de campo}

No ano de 2009, durante a etapa de Prospecção Arqueológica, o Sítio Arqueológico Porto Velho II foi identificado na vertente do Rio Grande, a aproximadamente 120 metros de sua margem (Figura 22). Na época, a maior parte do material arqueológico foi coletado superficialmente na Área de Proteção Permanente (APP), bem como no carreador adjacente. Vestígios arqueológicos em pouca quantidade foram evidenciados a cerca de 10 metros no plantio de cana-de-açúcar. Foram localizados e coletados dentro de seu perímetro 30 fragmentos de cerâmica, sendo identificadas as classes de parede e borda. O sítio apresentou, em todos os fragmentos, cerâmica lisa. Foram identificadas três bordas, mas em nenhum caso foi possível a reconstituição da forma do vaso (FACCIO, 2009).

Figura 22 - Localização do Sítio Porto Velho II

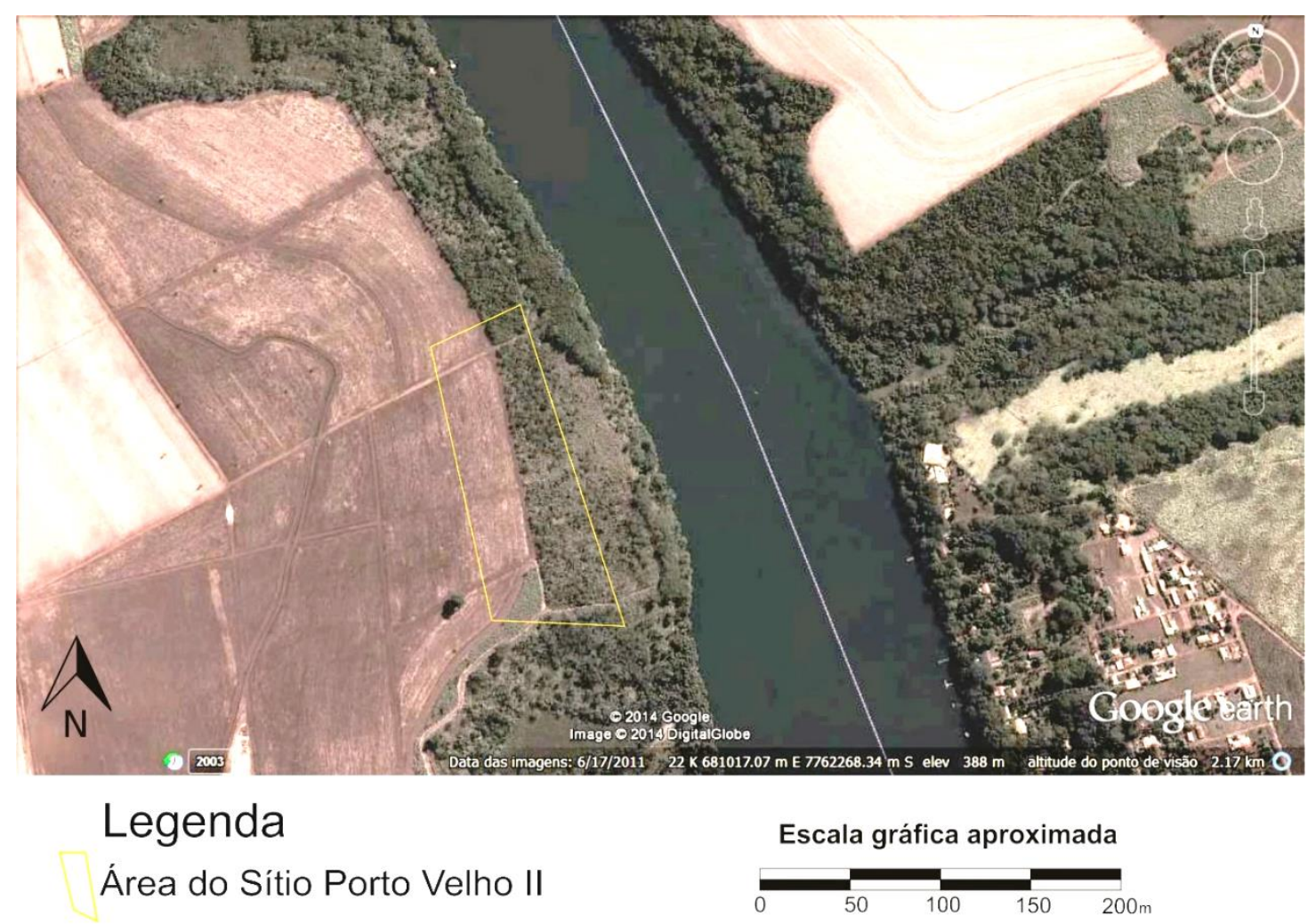

Fonte: Google Earth e Faccio (2009 e 2015). 
$\mathrm{Na}$ época, averiguou-se que os cortes de verificação não apresentaram material arqueológico em subsuperfície. Para a etapa seguinte, a do resgate arqueológico, foram propostos: limpeza da vegetação rasteira nas áreas de APP, coleta de superfície, acompanhamento sistemático da aragem da terra em épocas de plantio e abertura de poços-testes para verificação do subsolo (FACCIO, 2009).

No ano de 2013 e 2014 a equipe de arqueologia realizou a etapa de resgate arqueológico do Sítio Porto Velho II. Em diversas etapas de trabalho foram realizados caminhamentos sistemáticas de superfície, acompanhamento dos setores de aragens que abarcaram parte do sítio, limpeza da vegetação rasteira nas áreas de proteção permanente e execução de poços-testes. Esses procedimentos objetivaram identificar concentrações e dispersões de materiais arqueológicos.

Durante as coletas de superfície iniciais foram identificados e mapeados apenas três pontos. O primeiro acompanhamento de setor agrícola recém-arado ocorreu em Setembro de 2011, não sendo detectado material arqueológico. Optou-se, em Setembro de 2014, por realizar novo acompanhamento no setor agrícola, mas novamente não foi identificado material arqueológico.

O Sítio Porto Velho II dista apenas 1.600 metros do sítio Porto Velho I e sua disposição na paisagem, bem como a característica e a intensidade do material arqueológico foram muito semelhantes. Tendo como base as pesquisas efetuadas na área do Sítio Porto Velho I, adotamos metodologia parecida para o presente sítio, realizando pequenas intervenções subsuperficiais na área de proteção permanente adjacente ao carreador.

Nessa etapa foi selecionada uma área de 50x50 metros para que fossem confeccionadas as sondagens subsuperficiais. A seleção da área obedeceu aos mesmos critérios do Sítio Porto Velho I. A limpeza ocorreu em um quadrilátero de $20 \mathrm{~m}$ no eixo Norte-Sul e de 30m no eixo Leste-Oeste. Após a limpeza dessa área, foram realizadas inspeções superficiais para possíveis detecções de objetos ou vestígios arqueológicos. Nessa etapa foi identificado e coletado um fragmento de cerâmica em superfície. Após a inspeção superficial, optou-se por realizar prospecções subsuperficias com a ferramenta escavadeira manual do tipo "boca de lobo" em profundidade de $80 \mathrm{~cm}$. A distância entre cada sondagem permaneceu em 10 metros. Assim, na área de um quadrilátero foram confeccionados 12 sondagens subsuperficiais, quatro linhas de três sondagens em cada no eixo Norte-Sul e três linhas de três sondagens em cada no eixo Leste-Oeste. Os 
resultados das sondagens subsuperficiais revelaram a ausência de objetos ou indícios arqueológicos.

Diante dos resultados do trabalho de campo concluiu-se que se trata de um sítio com distribuição dos vestígios arqueológicos em uma dimensão aproximada de 260 metros de comprimento, na direção Norte-Sul, por 95 metros de largura na direção LesteOeste, com pequena quantidade de materiais arqueológicos. O Sítio Arqueológico Porto Velho II apresentou em sua coleção 39 fragmentos de cerâmica, um lítico polido e um lítico lascado (Figura 23).

Entendemos que as características apresentadas pelos Sítios Porto Velho I e Porto Velho II excluem a hipótese de tratar-se de uma antiga área de habitação. A baixa densidade de material arqueológico sugere tratar-se de pequenos abrigos próximos aos caminhos ou trilhas e às margens de rios (POSEY, 1979) ou áreas de atividades específicas interconectadas com as áreas de habitação (BINFORD, 1982; MORALES, 2007).

\subsubsection{Quadro geoambiental e pós-deposicional}

Unidade de Vertente: Declive Coluvial;

Elevação Topográfica: 388 metros;

Corpos de Água: Distante 50 metros do Rio Grande;

Descrição Geomorfológica: Entre Planícies Baixas, próximo a margem de rio, e Colinas Amplas, com topos extensos e aplainados e vertentes com perfis retilíneos e convexos;

Efeito Climático Local: Meses de Junho, Julho e Agosto com menor precipitação (mínima de 16,1mm) e meses de dezembro e janeiro como os mais chuvosos (máxima de $278,2 \mathrm{~mm})$;

Substrato Geológico/Pedológico: Inserido na Formação Serra Geral, apresentou pacote sedimentar profundo (média-baixa vertente) sendo prospectado subsuperficialmente $60 \mathrm{~cm}$ de profundidade sem que se pudesse detectar o embasamento rochoso, classe Latossolo Vermelho, matiz 2,5YR, com afloramento de blocos de rochas básicas próximo ao talvegue do Rio Grande;

Uso e Ocupação do Solo: Lavoura de Cana-de-açúcar, onde se realizam atividades como o preparo do solo, cultivo e tratos culturais.

Intemperismo e Bioturbação: Decomposição das rochas básicas próximas ao talvegue do Rio Grande por meio da meteorização química e bioquímica. 
Atividades Antrópicas: Preparo do solo implicando subsolagem, gradagem pesada (grades de 20 discos com diâmetros de 30 a 32cm), aração com aveica (inversão de uma camada de 40 a $45 \mathrm{~cm}$ de espessura) e construção de carreadores.

Processos Erosivos/Deposicionais: Ocorre na unidade declive coluvial forte perturbação da superfície e subsuperfície pela retirada da vegetação e atividades agrícolas, provocando durante a época de chuvas, erosão linear com fluxo concentrado de água, confeccionando sulcos nas áreas de carreadores e nos caminhos que levam aos cursos de água. $\mathrm{Na}$ área de plantio não foi possível identificar feições erosivas devido as recém aragens efetuadas no local.

Vegetação Remanescente: Angico (Anadenanthera spp); Figueira (Ficus Citrifolia); Jatobá (Hymenaea Courbaril); Embaúba (Cecropia Pachystachia); Monjoleiro (Senegalia Plyphylla); Macaúba (Acrocomia Aculeata); Bacuri (Attalea Phalerata);

Áreas de Captação de Matéria Prima: Notou-se nas áreas adjacentes aos carreadores seixos de matéria prima diversificada. No entanto, sabe-se que essa matéria prima foi transportada de outra região para pavimentar as áreas mais degradadas desses caminhos. Segundo os trabalhadores esses seixos foram coletados do Rio Grande. Nas proximidades não foi detectada fontes de argila que pudessem ter sido usadas para confecção de recipientes cerâmicos;

Processos pós-deposicionais atuantes sobre o registro arqueológico: Pôde-se notar acúmulo de materiais arqueológicos nas áreas de carreadores e redes erosivas formadas na baixa vertente. A descida de materiais arqueológicos ocorreu devido ao escoamento pluvial que transportou os materiais arqueológicos expostos em superfície e nas camadas menos espessas dos solos arados. Por outro lado, atividades antrópicas como subsolagem, gradagem e aragem provocaram severos deslocamentos verticais dos vestígios arqueológicos e redução dos mesmos. 
Figura 23 - Dispersão dos materiais arqueológicos no sítio Porto Velho II

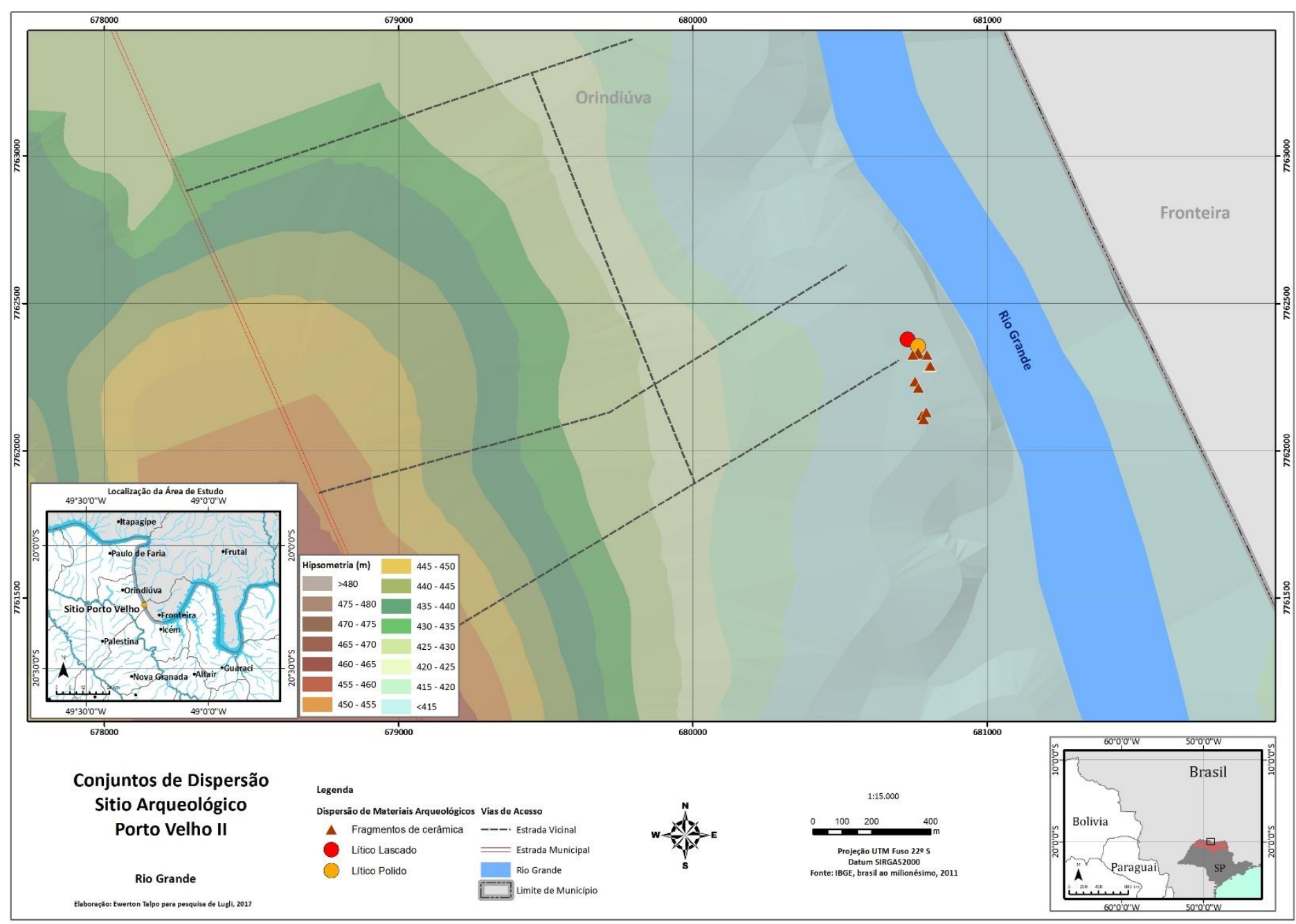

Fonte: IBGE. Confecção: Ewerton Talpo e David Pereira. 


\subsubsection{Análise da coleção arqueológica}

O lítico lascado

No do Sítio Arqueológico Porto Velho II identificou-se uma lasca de arenito silicificado (Foto 5).

Foto 5 - Laca de arenito silicificado coletada no Sítio Arqueológico Porto Velho II.

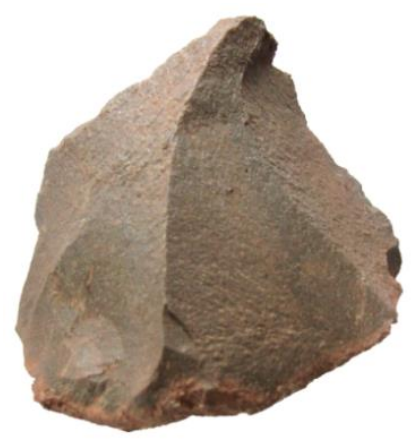

Fonte: Faccio, 2015

Os fragmentos de cerâmica

O material cerâmico do Sítio Arqueológico Porto Velho II é proveniente de coleta de superfície e de cortes de verificação, realizados no momento da prospecção. Pelo fato do Sítio Porto Velho II não ter apresentado vasilhas cerâmicas inteiras, o primeiro encaminhamento proposto para a análise do material foi o de agrupar os fragmentos de um mesmo vaso em conjuntos. Esse encaminhamento mostrou a ausência de conjuntos. Dessa forma, trabalhou-se com os fragmentos individualmente. A Tabela mostra as classes de peças evidenciadas no Sítio Arqueológico Porto Velho II.

Tabela 6 - Classe de Peças Cerâmicas identificados no Sítio Porto Velho II, Orindiúva, SP.

\begin{tabular}{l|l}
\hline Classe & Quantidade de Peças \\
\hline Parede & 27 \\
\hline Borda & 3 \\
\hline Total & 30 \\
\hline
\end{tabular}


Foram identificadas apenas as classes parede e borda, totalizando 30 fragmentos. O sítio apresentou, em todos os fragmentos, cerâmica lisa. Foram identificadas três bordas, mas em nenhum caso foi possível à reconstituição da forma do vaso.

$\mathrm{Na}$ relação estabelecida entre o uso barbotina e o tipo de pasta, predominou a não utilização da barbotina em três tipos de pasta: plástica, intermediária e dura (indicadas pela quantidade de antiplástico misturado à argila no fabrico das peças). Em um fragmento ocorreu o uso da barbotina associado ao uso da pasta plástica e em outro fragmento ocorreu o uso da barbotina na face interna associado ao uso da pasta plástica. Associado ao uso da pasta intermediária ocorreu um fragmento onde com uso da barbotina na face externa e interna e em outros dois fragmentos ocorreu o uso da barbotina somente na face interna. Associado ao uso da pasta dura ocorreu um fragmento com uso da barbotina somente na face interna.

\subsubsection{O Sítio Arqueológico Menino Jesus}

\subsubsection{O Trabalho de campo}

O Sítio Menino Jesus está inserido em área de depleção do Reservatório da UHEMarimbondo, na cidade de Icém, SP. Esse reservatório localiza-se no Rio Grande e é responsável pela inundação do Córrego Menino Jesus onde foi detectado o sítio de nome homônimo.

No ano de 2009, durante a etapa de Prospecção Arqueológica, o Sítio Arqueológico Menino Jesus foi identificado na área de depleção e de proteção permanente do Rio Grande, sendo que no período de chuvas o sítio fica submerso nas águas do lago da UHE - Marimbondo. A primeira detecção de material apresentou fragmentos de cerâmica do Sítio Arqueológico Menino Jesus proveniente de coleta de superfície, realizada no ano de 2009 (FACCIO, 2009).

$\mathrm{Na}$ época, que foi planejado se efetuassem monitoramento e resgate dos materiais arqueológicos nos períodos de menor vazão do Rio Grande. Assim, nos meses de Agosto, Setembro e Novembro de 2013 a equipe de arqueologia retornou a área do Sítio Arqueológico Menino Jesus para realizar a monitoria, coleta de superfície e georreferenciamento dos vestígios arqueológicos e geoindicadores. 
As águas regidas pela UHE - Marimbondo estavam recuadas e durante as caminhadas no entorno do lago foi possível avistar um trecho de terra que apresentou áreas alagadiças, cobertura vegetal ressecada e arbustos secos. Esse trecho foi percorrido integralmente no seu lado direito até a intersecção com o Canal maior do Rio Grande (Foto 6). Notou-se a presença de afloramento de basalto no local, seixos de silexito aptos ao lascamento, material lítico lascado sobre seixo, material lítico polido e alguns possíveis amoladores fixos em basalto, como podemos ver nas Fotos.

Foto 6 - Vista Panorâmica da área do sítio e de seu entorno. A seta laranja indica a faixa de depleção onde foram coletados materiais líticos e afloramentos de basalto. A seta vermelha indica as águas do Córrego Menino Jesus represada. A seta preta indica o canal principal do Rio Grande.

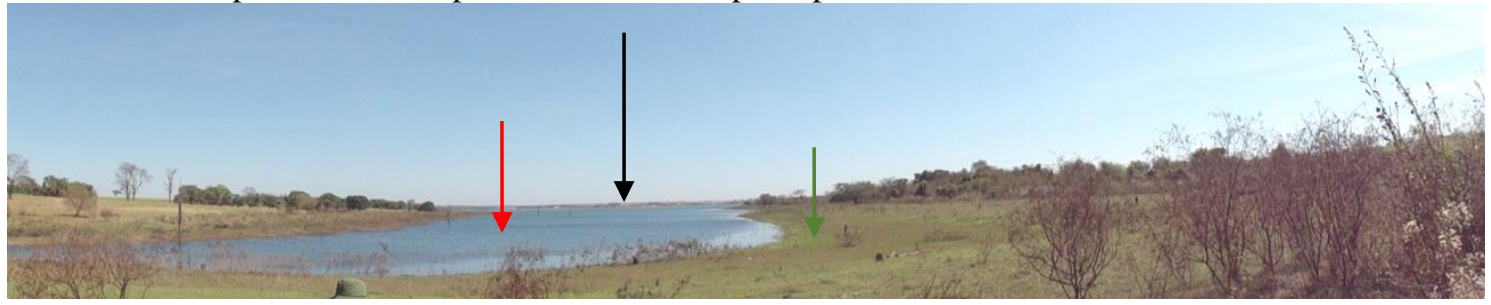

Fonte: Faccio, 2015

Foto 7 - Lítico polido (mão de pilão fragmentada).

Foto 8 - Afloramento de basalto na margem direita do Córrego Menino Jesus.
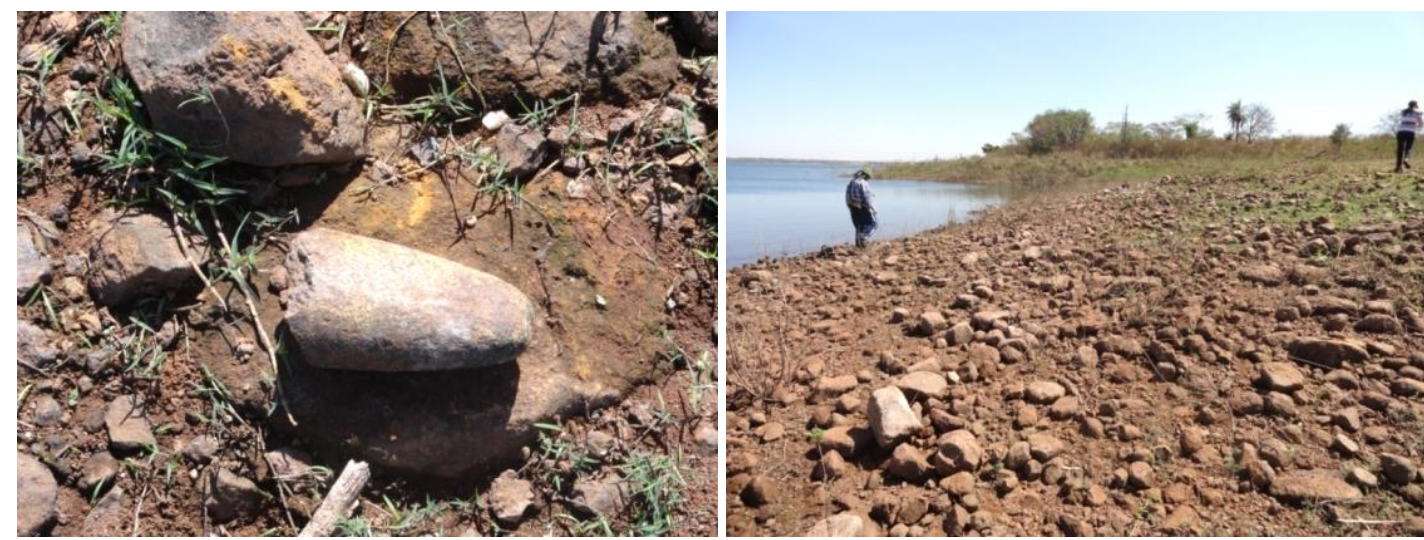

Fonte: Faccio, 2015

Avaliação em Setembro de 2013

No mês de Setembro o sítio recebeu novo monitoramento, sendo que nessa etapa as duas margens foram vistoriadas. Neste monitoramento a equipe dividiu-se em duas partes objetivando cobrir as duas margens do Córrego Menino Jesus, atualmente represado pela UHE-Marimbondo. O caminhamento sistemático nas áreas adjacentes as 
margens não revelaram objetos arqueológicos móveis, provavelmente, porque as águas da represa não estavam recuadas suficientemente para que esses materiais fossem evidenciados, como no ano de 2009.

No entanto, a ênfase do monitoramento foi dada ao georreferenciamento dos blocos de basalto com possíveis marcas de amolador, como apresentados nas Fotos 4 e 5. Essas rochas de tamanhos diferenciados exibiram marcas de possíveis usos com profundidade e forma dos seus sulcos diferenciadas, apresentando-se na margem direita do córrego. Essas possíveis oficinas de polimento podem caracterizar-se como evidências da ação humana resultantes da fricção de rochas móveis durante o processo de confecção de artefatos líticos (HERBERTS et. al. 2006) como os evidenciados neste mesmo sítio.

Foto 09: Bloco de basalto com dois sulcos em Foto 10 - Detalhe no sulco mais profundo. forma de X. Posição UTM: 22K 693026 - 7752216

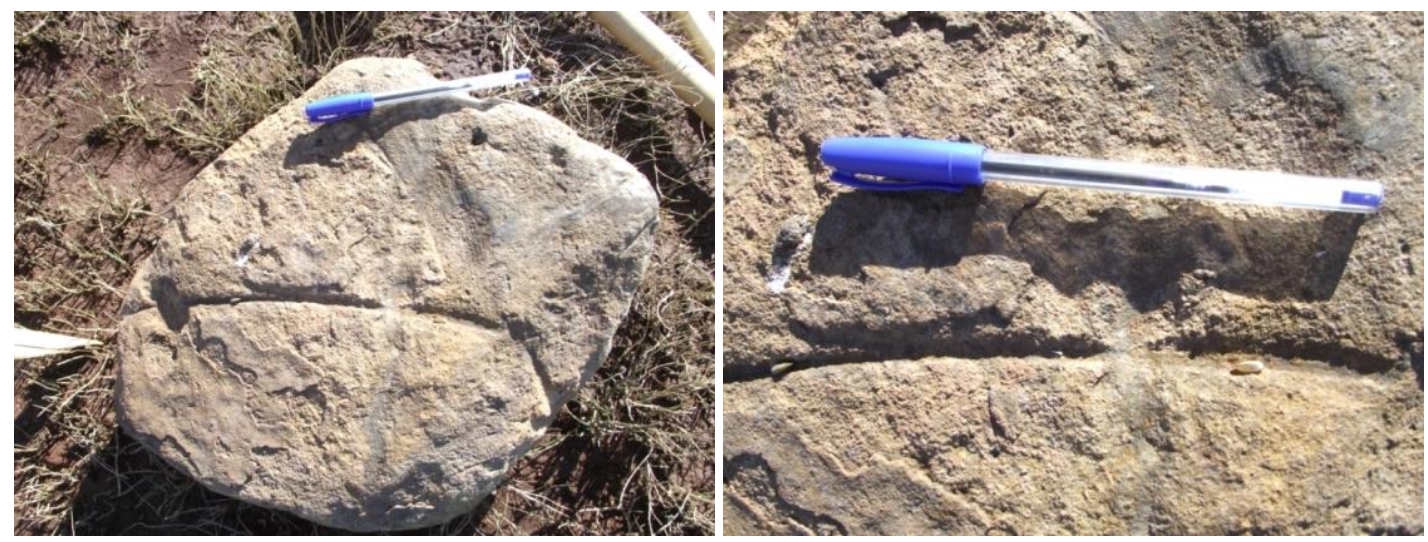

Fonte: Faccio, 2015

Avaliação em 14 de Novembro de 2013

A última etapa de monitoramento arqueológico no Sítio Menino Jesus no ano de 2013 aconteceu no mês de Novembro. O objetivo deste novo monitoramento foi realizar novas caminhadas sistemáticas na margem direita do Córrego Menino Jesus após a informação de que a represa da UHE - Marimbondo havia recuado suas águas devido a dinâmica das turbinas da Usina Hidroelétrica.

Ao chegar na área do sítio notamos que as águas recuaram alguns metros em relação ao mês de Setembro deste mesmo ano. Assim, uma equipe foi formada para a execução dos caminhamentos sistemáticos. Os poucos metros de recuo foram o bastante para que pudessemos evidenciar, georreferenciar e coletar fragmentos de cerâmica e lítico 
lascado dispersos paralelamente ao córrego em uma distância de aproximadamente um quilômetro.

Neste momento foi prospectada a cabeceira de drenagem do córrego em apreço, onde pudemos notar a presença de fontes de argila, ainda submersas pelas águas, que no entanto puderam ser georreferenciadas e descritas como possíveis matérias-primas para a produção de potes de cerâmica, compondo, neste cenário de ocupação, um importante geoindicador.

A estiagem do ano de 2014 e o ressurgimento do Sítio Menino Jesus

O ano de 2014 caracterizou-se pela forte estiagem que se abateu sobre a região sudeste do Brasil. No estado de São Paulo a seca foi uma das mais graves já registradas. Segundo os dados do IAG-USP esta foi a temporada de menor índice pluviométrico desde 1969 (http://www.ccst.inpe.br/).

Observando o gráfico de precipitação apresentada na Figura 24 nota-se que os indíces pluviométricos dos meses de Novembro de 2013 à outubro de 2014 ficaram bem abaixos da média histórica de chuvas, com excessão do mês de julho de 2014. Segundo este gráfico, no mês de Novembro de 2014 as chuvas voltaram a ocorrer com normalidade no estado de São Paulo.

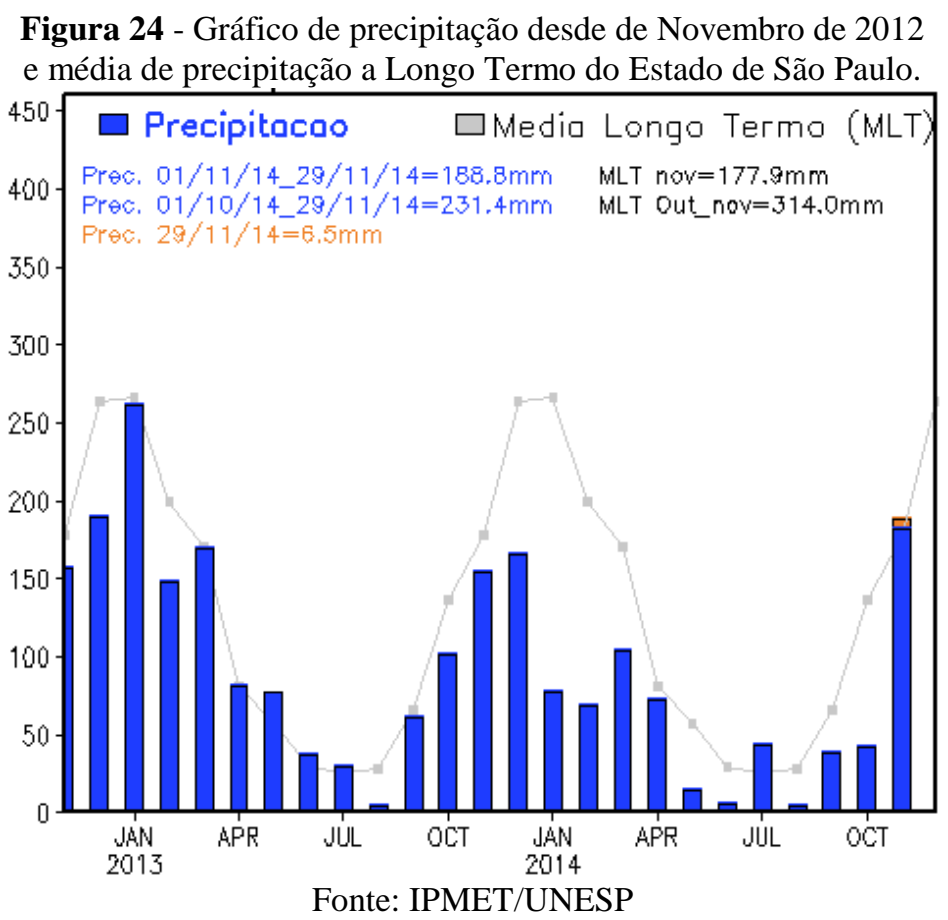


O baixo volume de precipitação nos meses finais de 2013 e nos meses de 2014 alteraram significativamente o regime de vazão natural da UHE-Marimbondo. Segundo o gráfico da Figura 25 os valores de vazão natural começaram a decair consideravelmente, em relação à média de longo termo, a partir de Novembro de 2013, atingindo um cenário extremamente crítico nos meses de janeiro a Outubro de 2014. O déficit hídrico na região atingiu o volume útil da represa que despencou a níveis mínimos nos meses de setembro a outubro de 2014.

No mês de Setembro de 2014 a equipe de arqueologia coordenada pela Profa. Neide Barrocá Faccio, complementada por uma equipe de trabalhadores da Usina Bunge - Moema, mobilizou-se para realizar mais uma etapa de salvamento no Sítio Menino Jesus. O objetivo foi realizar caminhamento sistemático e identificar os vestígios arqueológicos até então submersos pelas águas represadas.

Nesta fase de trabalho constatamos que a represa da UHE - Marimbondo havia reduzido ao fio de água em boa parte do Córrego Menino Jesus (Fotos de 12 a 17). Com a exposição do fundo de vale e da baixa vertente adjacente ao corpo de água foram evidenciados milhares de vestígios arqueológicos em suas margens.

Figura 25 - Gráfico de vazão natural e volume útil da represa UHE-Marimbondo desde Julho de 2012.

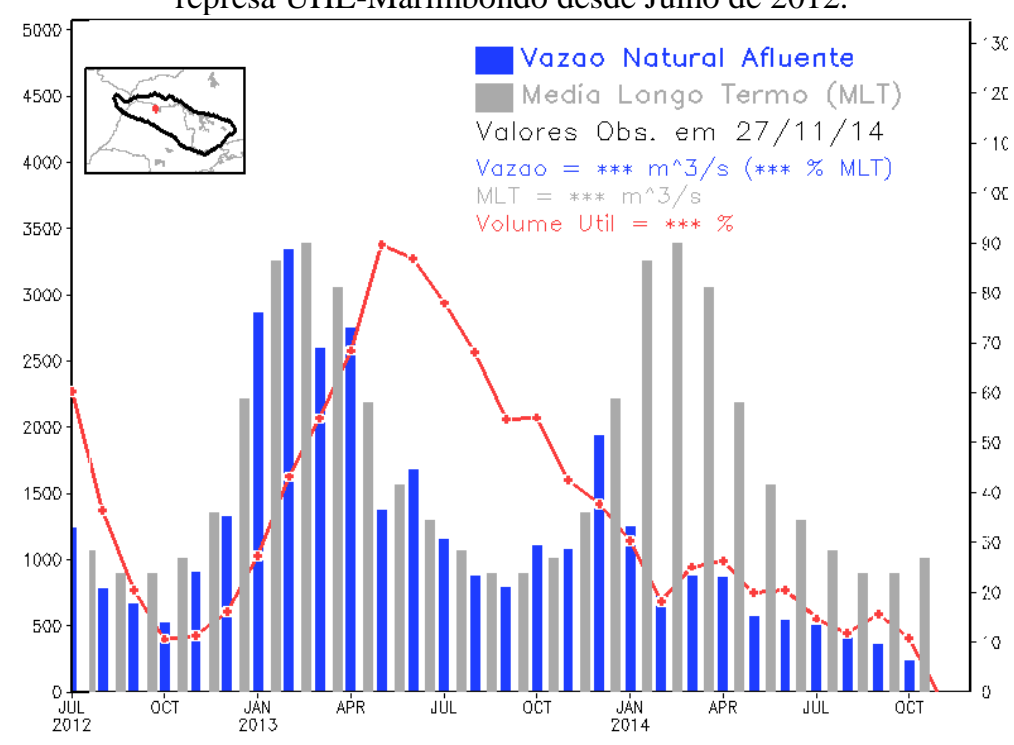

Fonte: IPMET/UNESP

Os trabalhos arqueológicos no mês de Setembro caracterizaram-se pelo: 1levantamento da flora nativa adjacente ao sítio, 2- mapeamento e coleta de argila nas fontes prospectadas, 3- mapeamento das nascentes próximas ao sítio, 4- 
georreferenciamento do trecho a "fio de água" do córrego Menino Jesus, 5- mapeamento e coleta dos vestígios arqueológicos de superfície, 6- delimitação espacial do sítio arqueológico, 7- seleção de uma área para decapagem, 8- abertura de quadras para a escavação, 9- decapagem realizada pelo método de supreção das camadas estratigráficas por níveis artificiais e 10- plotagem dos vestígios arqueológicos em croqui de quadras.

Uma nova paisagem apresentou-se com a delimitação visual do Córrego Menino Jesus, suas dezenas de nascentes e fontes de argila espalhadas por centenas de metros de sua margem esquerda, grande quantidade de materiais arqueológicos dispersos em superfície, formando duas áreas de concentração, sobretudo do lado esquerdo do córrego, afloramento de piso basáltico, entre outras características que ainda não haviam sido detectadas.

Diante dos resultados do trabalho de campo conclui-se que tratava-se de um sítio com distribuição dos vestígios arqueológicos em uma dimensão aproximada de 1320 metros de comprimento, na direção N - S, por 890 metros de largura na direção L - O.

Fotos 11 e 12 - A Foto 11 registra a represa da UHE-Marimbondo no dia nove de setembro de 2013. A Foto 12 registra o forte decréscimo do volume útil chegando ao fio de água do Córrego Menino Jesus no dia quatro de setembro de 2014.
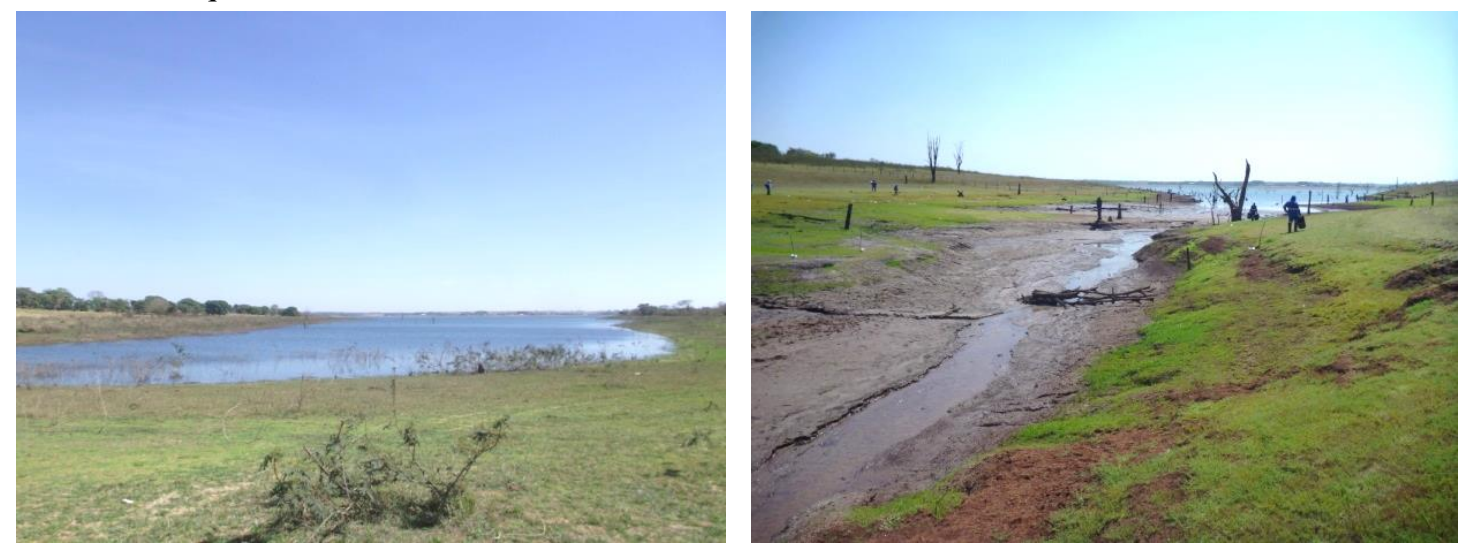

Fonte: Faccio, 2015 
Fotos 13 e 14 - A Foto 13 mostra afloramento de água escoando para o Córrego Menino Jesus em sua margem esquerda. A Foto 14 indica na seta vermelha depósito de argila sendo prospectado e a seta preta indica afloramento de água.
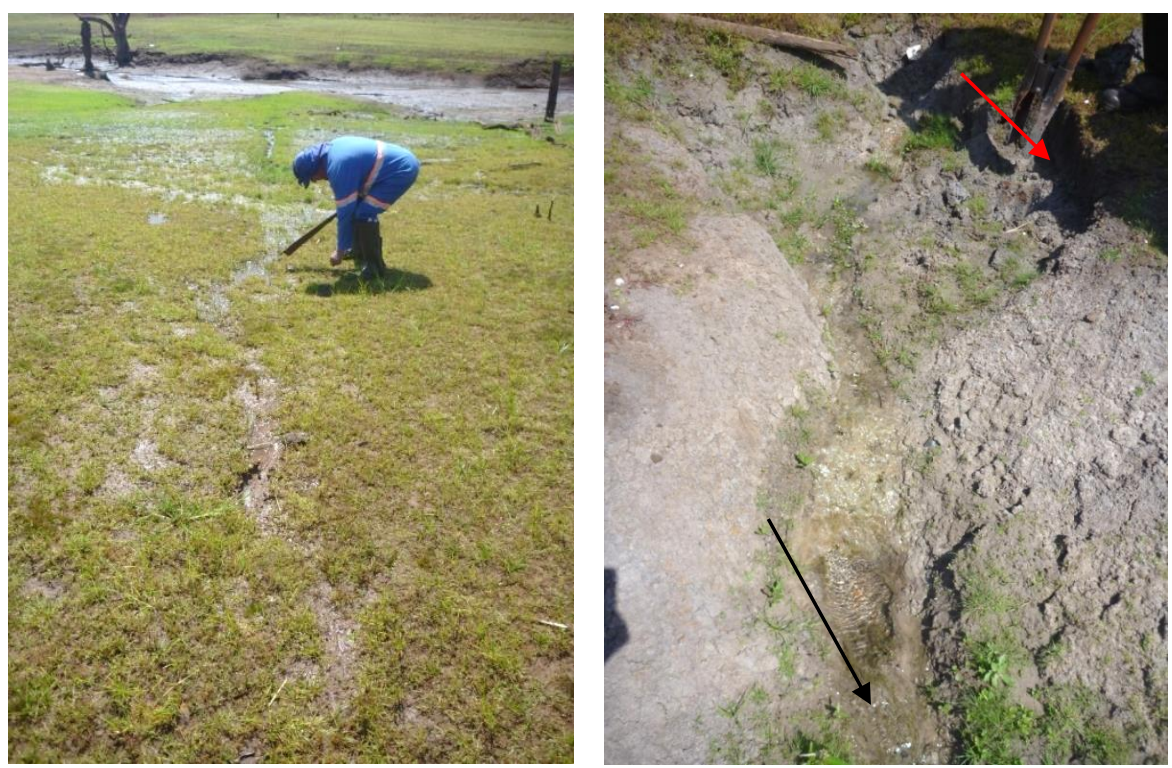

Fonte: Faccio, 2015

Fotos 15 e 16 - A seta preta da Foto 15 indica o afloramento das raízes de duas Macaúbas. O processo ocorreu por meio da erosão da água que carreou o solo e os vestígios arqueológicos para o fundo de vale. A Foto 16 indica em suas circunferências vermelhas as áreas onde foram coletados materiais arqueológicos na margem esquerda. A seta preta indica a área de concentração 1 e a seta azul a área de concentração 2.

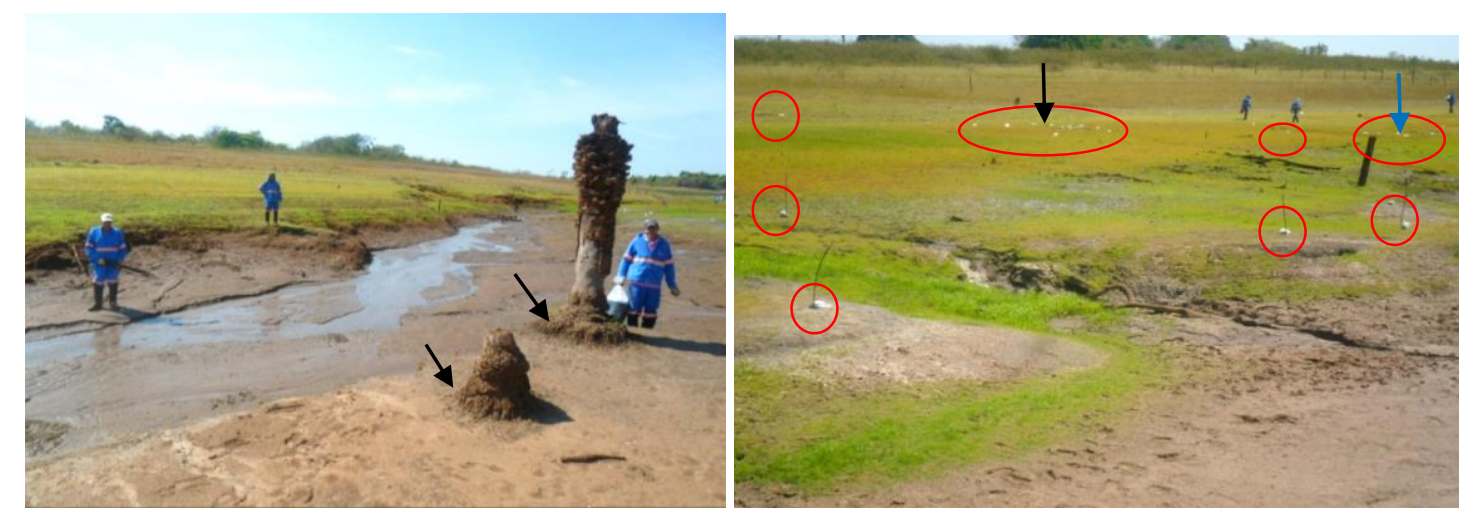

Fonte: Faccio, 2015

\section{Escavação Arqueológica}

Essa etapa de investigação foi determinada pelos resultados das sucessivas coletas sistemáticas que direcionaram os locais para escavação, bem como, as quadras a serem escavadas dentro desses locais escolhidos. Assim, após a delimitação de duas áreas de 
concentração de material arqueológico, inseridas na margem esquerda do córrego, foi possível visualizar com eficácia o contexto arqueológico sobre a paisagem.

Embasado na concentração de vestígios arqueológicos em superfície, correspondentes, espacialmente, a área de concentração 1, decidimos por estabelecer na coordenada UTM 692930.311 E - 7752164.912 N o ponto zero para o quadriculamento da área de decapagem. Nos alinhamentos das quadras de escavação, foram marcados pontos com piquetes de 2 × 2 metros. Após essa etapa, dividiu-se as quadras em A1, A2, B2 e C2, resultando em uma área de escavação de $4 \mathrm{~m}$ (eixo nordeste-sudoeste) por $6 \mathrm{~m}$ (eixo sudeste - noroeste).

Após o quadriculamento da área eleita, foram realizadas limpezas superficiais com enxada, pá de pedreiro e pincel sobre as gramíneas e sedimentos superficiais, evidenciando, assim, os materiais aflorantes. Fragmentos de cerâmica, líticos lascados, seixos, blocos de hematita e coquinhos de Macaúba foram coletados em sacos separados e plotados em croquis de campo.

Com o perímetro das quadras de escavação limpo, deu-se início a decapagem por níveis artificiais suprimindo os estratos em intervalos de $10 \mathrm{~cm}$. Cientes dos processos pós-deposicionais atuantes sobre a paisagem do sítio arqueológico (técnicas agrícolas de aragem antes de 1975, desflorestamento das matas galerias para a construção e represamento das águas no âmbito da UHE-Marimbondo, bem como a dinâmica de áreas de depleção) o objetivo da escavação por níveis artificiais foi buscar uma relação estatística da área decapada com seus níveis estratigráficos, visualizando o lócus horizontal e a quantidade de peças coletadas em cada nível.

Acreditamos que o controle apurado das técnicas de coletas sistemáticas superficiais e de escavação por níveis artificiais resulte em uma série de dados que possibilite a obtenção e acúmulo de informações a respeito do quadro crono-cultural e da dinâmica dos sistemas socioculturais existentes no período pré-colonial nessa região. (ALVES et. al. 2013)

Nessa perspectiva de trabalho, foram suprimidos os estratos até o nível de $30 \mathrm{~cm}$ de profundidade. Os níveis iniciais $(0-15 \mathrm{~cm})$ apresentaram a maior quantidade de materiais arqueológicos (fragmentos de cerâmica, lítico lascado e blocos de hematita ${ }^{70}$ ) e vestígios pós deposicionais (coquinhos de Macaúba, conchas de moluscos, madeira

\footnotetext{
${ }^{70}$ Consideramos os blocos de hematita como parte do contexto arqueológico. A hematita esteve presente em praticamente todas as quadras de escavação e está sendo documentada como tempero predominante nos fragmentos de cerâmica analisados.
} 
decomposta e solo enegrecido). No segundo nível $(10 \mathrm{~cm}-20 \mathrm{~cm})$ da Quadra A1 foi recuperado em quase sua totalidade um pote cerâmico fragmentado. A partir do nível três $(20 \mathrm{~cm}-30 \mathrm{~cm})$ os materiais arqueológicos e os vestígios pós deposicionais foram paulatinamente escasseando até se chegar a uma camada estéril (Figura 5). A continuidade da supressão dos níveis estratigráficos foi interrompida após os $30 \mathrm{~cm}$ de profundidade devido ao afloramento de água.

O mesmo procedimento técnico descrito para a área de escavação 1 ocorreu para a área de escavação 2, situada a 16 metros a Noroeste. O procedimento envolveu a abertura de três quadras de 2 × 2 metros (L4, M3 e M4).

A supressão dos níveis artificiais nesse contexto de escavação se deu até os centímetros iniciais. Por apresentar-se como área próxima as águas represadas, a partir do dia 18 de Setembro e, sobretudo, no dia 19 de Setembro ocorreu o avanço da represa em direção as suas margens. Com a elevação do reservatório as nascentes adjacentes deixaram de drenar suas águas provocando o encharcamento dessas quadras de escavação, interrompendo-se assim os trabalhos.

Os materiais identificados no Sítio Arqueológico Menino Jesus dividem-se em três classes diferentes, a saber, líticos lascados, líticos polidos e material cerâmico. A dispersão dos pontos de coletas do ano de 2013 e 2014 podem ser vistas na Figura 26.

As Fotos de 17 a 29 mostram cenas do trabalho de escavação do Sítio Menino Jesus.

Foto 17 - Abertura das quadras A1, A2, B2 e C2 na área de concentração 1.

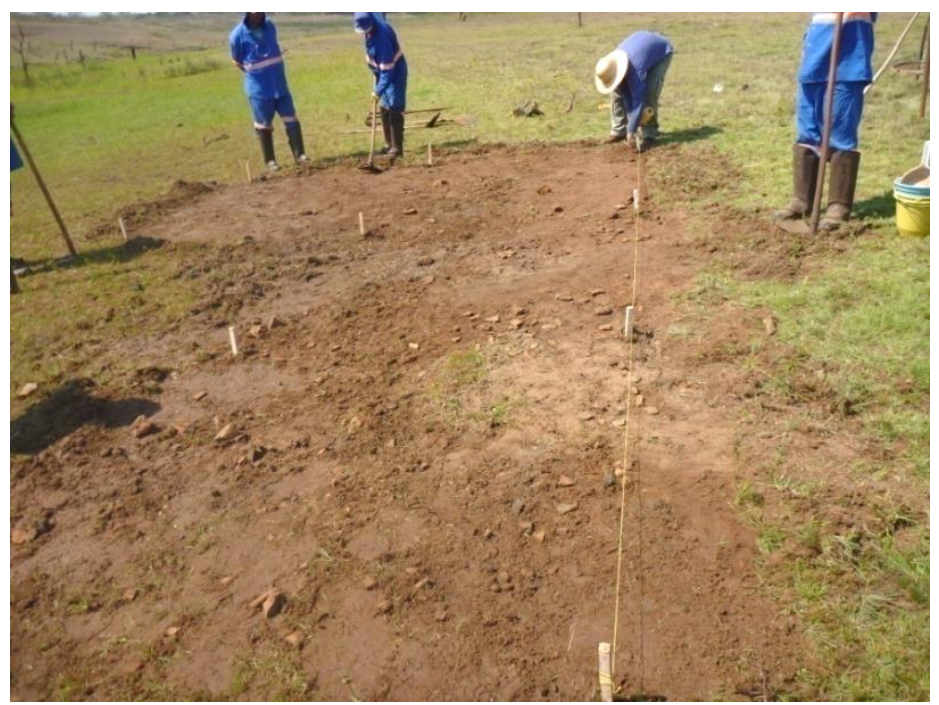

Fonte: Faccio, 2015 
Fotos 18, 19 e 20: Sequência de imagens que identifica, da esquerda para a direita, a coleta de superfície das quadras C2, B2, A2 e A1.
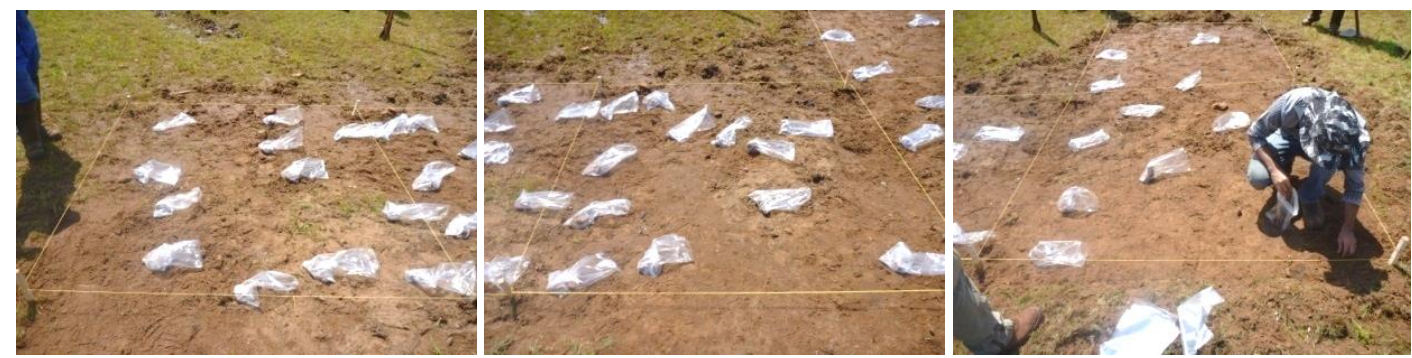

Fonte: Faccio, 2015

Foto 21 - Escavação do Nível 1 da Quadra 1. A seta preta indica um fragmento de parede, a seta amarela um coquinho de Macaúba e a seta vermelha um fragmento de base. Nota-se o encharcamento do solo devido a proximidade das nascentes de água.

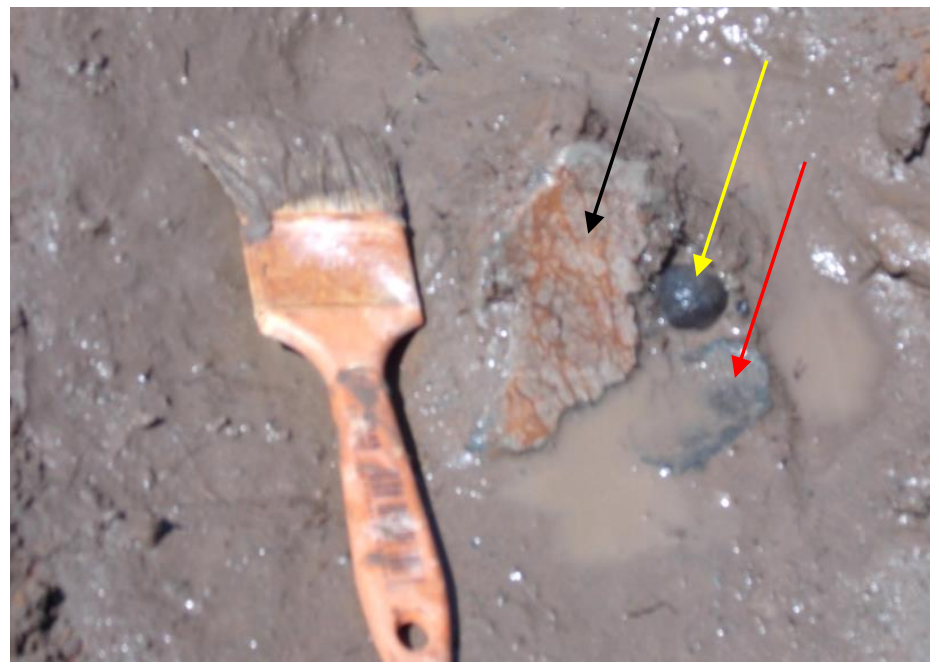

Fonte: Faccio, 2015

Fotos 22 e 23 - As fotos mostram manchas escuras que surgem após os primeiros centímetros decapados. Na foto 24 após a supressão de $10 \mathrm{~cm}$ de profundidade as manchas negras se tornam mais evidentes. Essas manchas, provavelmente, são testemunhos pós deposicionais da recomposição de matéria orgânica pelas águas da represa UHE-Marimbondo.
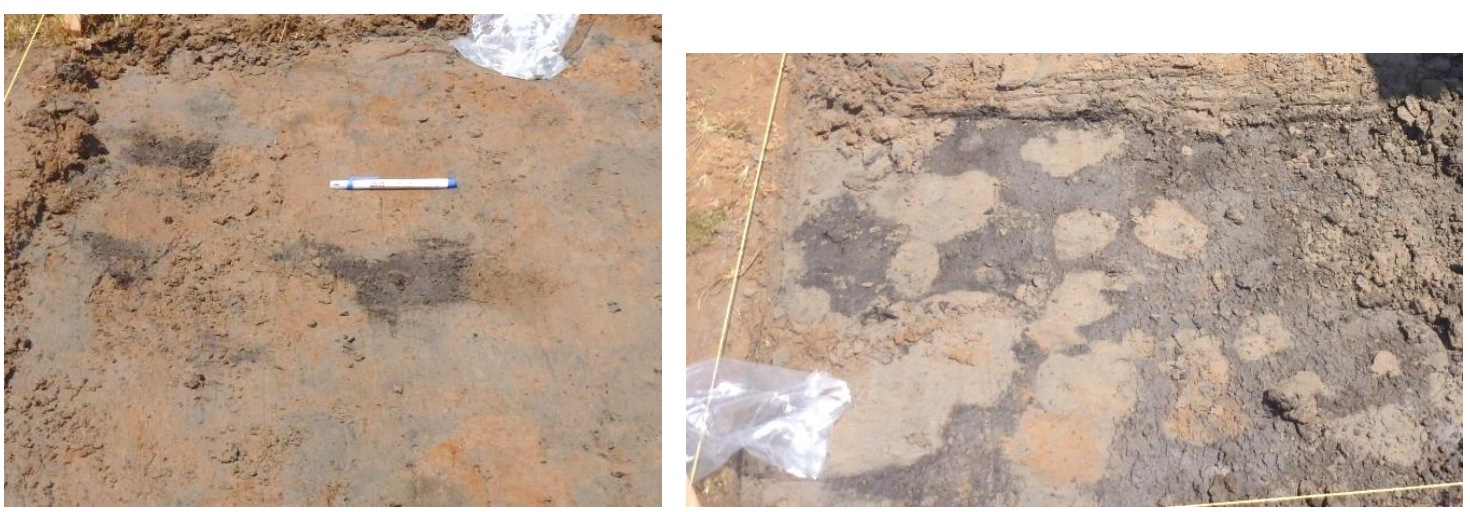

Fonte: Faccio, 2015 
Foto 24 - Nota-se nas circunferências pretas as áreas de maior ocorrência das manchas enegrecidas pela decomposição de matéria orgânica pós deposicional (Quadras A1 e A2 Nível 1). A seta preta indica área de nascente com suas adjacencias encharcadas. Ao fundo a represa da UHE-Marimbondo.

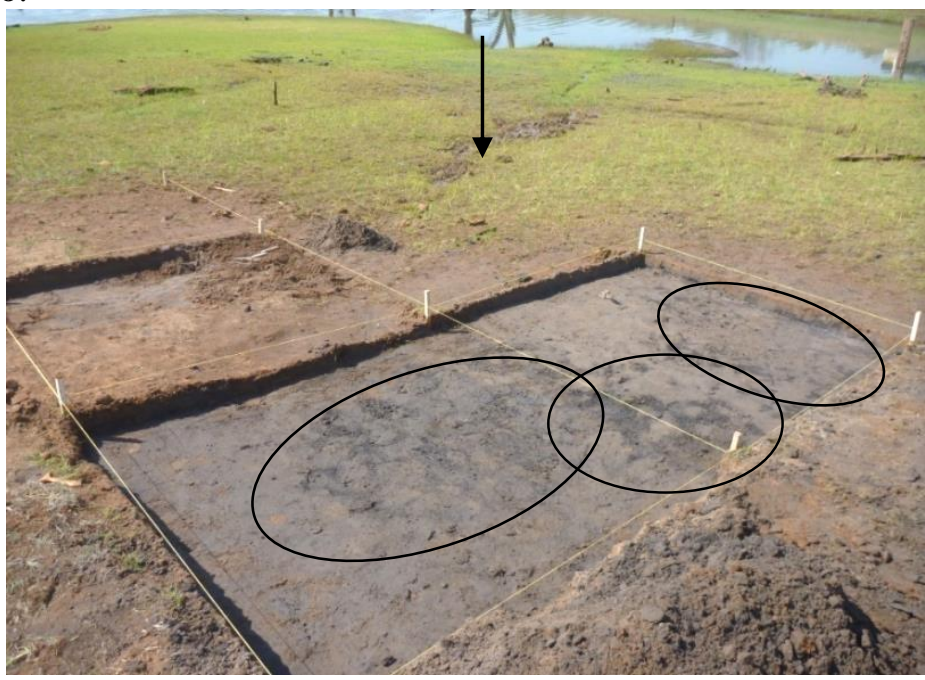

Fonte: Faccio, 2015

Foto 25 - Nível 2 Quadra A1. Fragmentos de parede, borda e base de um mesmo pote. Notou-se que no nível 2 as cerâmicas se tornaram menos fragmentadas.

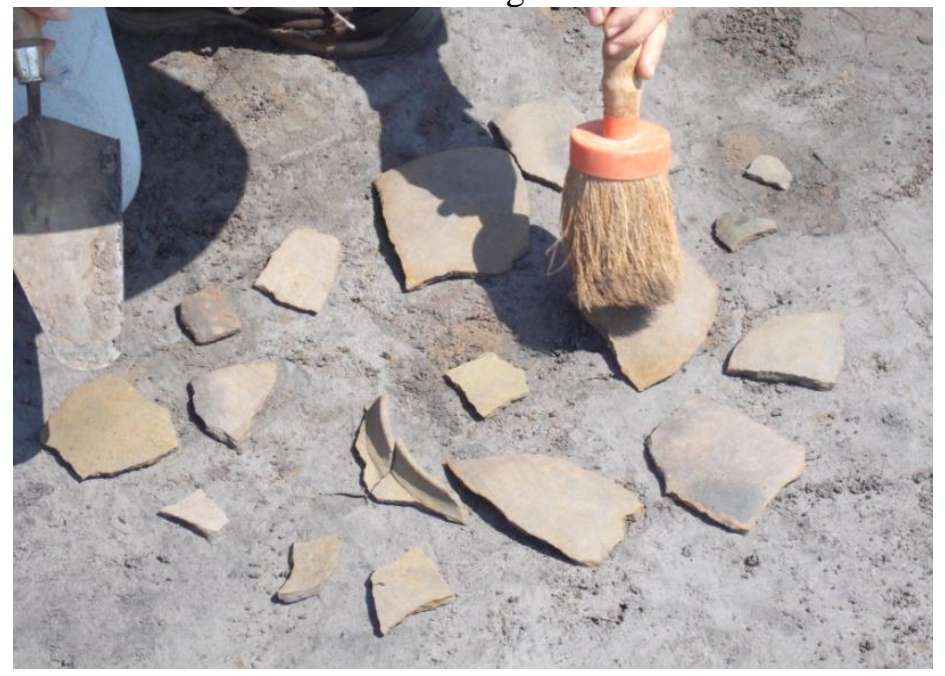

Fonte: Faccio, 2015 
Foto 26 - Nível 2 Quadra A1. Reconstituição de pote cerâmico.

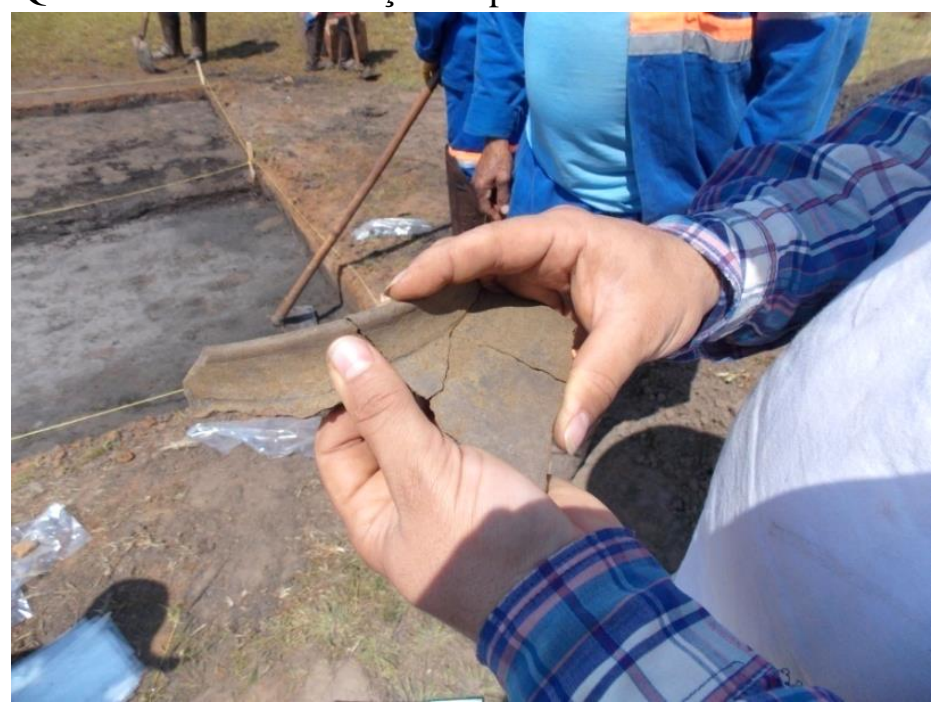

Fonte: Faccio, 2015

Foto 27 - Supressão do Nível 2 das Quadras C1, B1, A1 e A2. A seta preta indica um bloco testemunho localizado na quadra $\mathrm{C} 1$. Ao fundo o terreno encharcado e a represa da UHEMarimbondo.

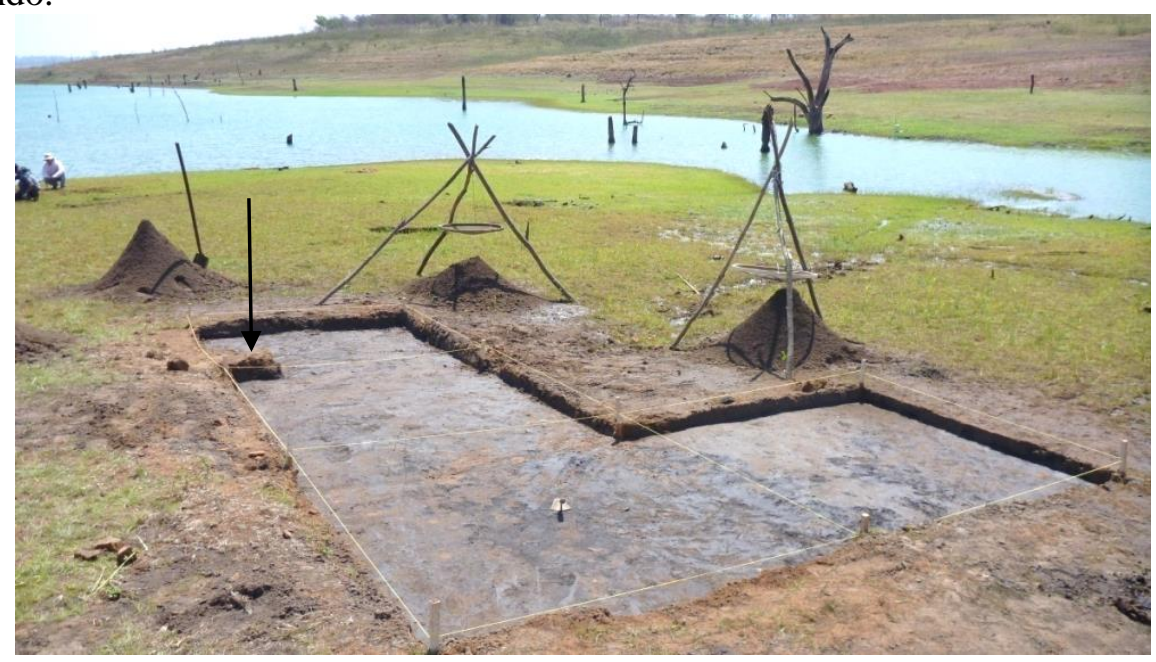

Fonte: Faccio, 2015 
Foto 28 - Paisagem de entorno da área de escavação 1. A seta preta indica as quadras de escavação, a seta azul a nascente e seu canal até o Córrego Menino Jesus e o círculo vermelho o terreno encharcado. Nota-se ao fundo a vertente que assenta o sítio em apreço e seus recursos naturais. Foto tirada da margem direita.

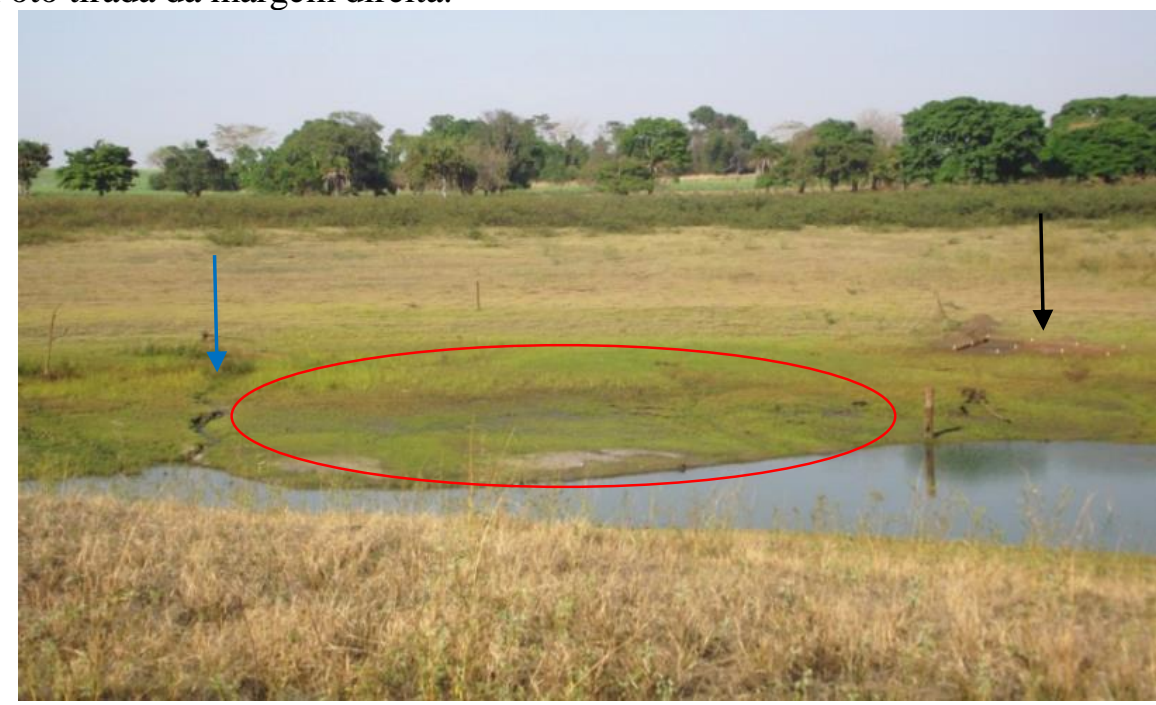

Fonte: Faccio, 2015

Foto 29 - A seta preta indica a área de escavação 1, a seta vermelha indica a área de escavação 2, a seta verde indica as águas represadas do Córrego Menino Jesus, a seta azul indica o curso do Rio Grande e a seta amarela a margem direita do Córrego em apreço.

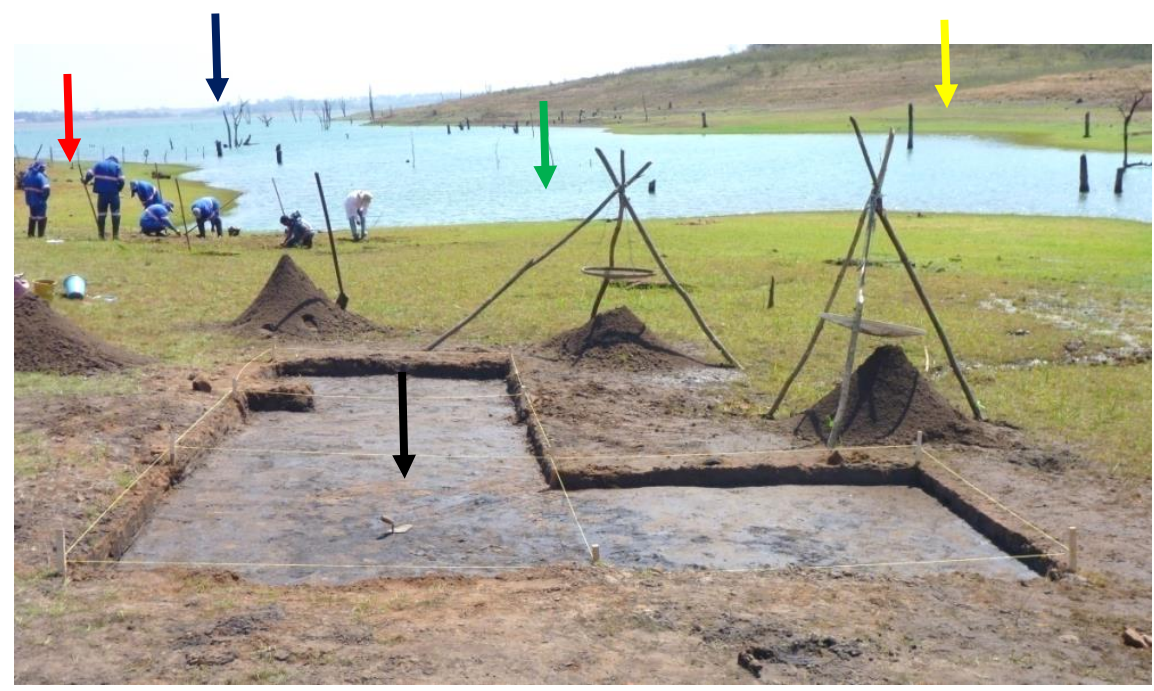

Fonte: Faccio, 2015 
Figura 26 - Quadra A1 N1. Localização de vestígios arqueológicos na área de decapagem do Sítio Menino Jesus.

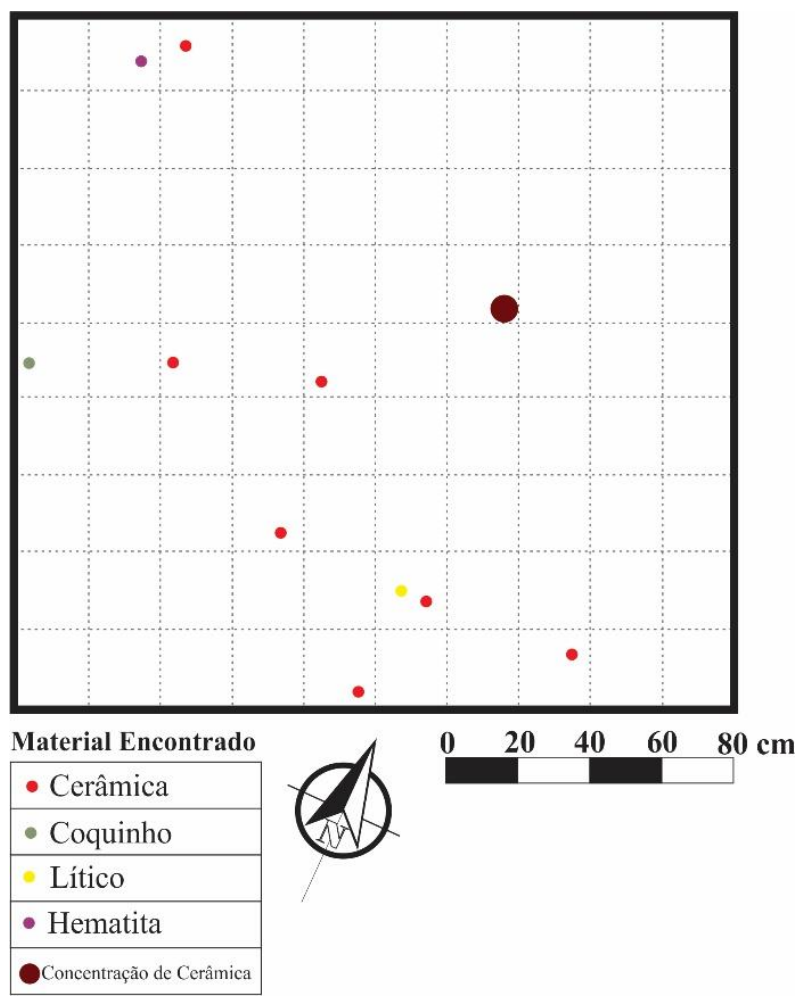

Fonte: Faccio, 2015

Figura 27 - Quadra A1 N2. Localização de vestígios arqueológicos na área de decapagem do Sítio Menino Jesus.

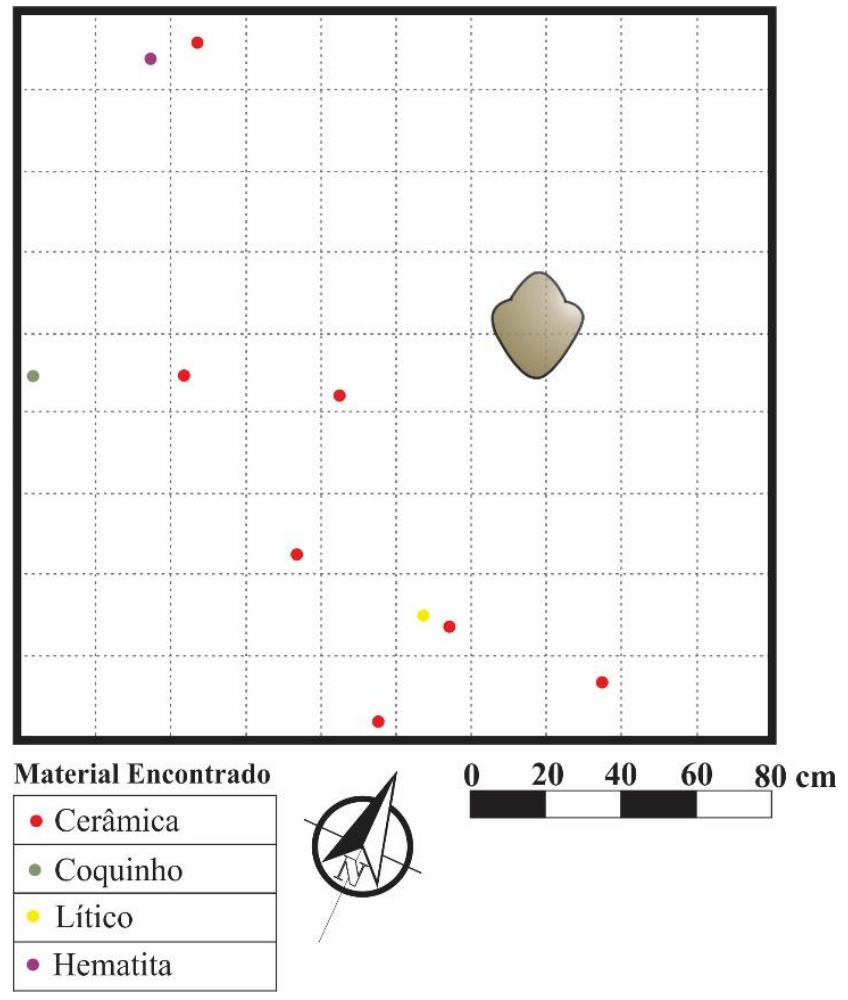

Fonte: Faccio, 2015 
Figura 28 - Quadra A1 N3. Localização de vestígios arqueológicos na área de decapagem do Sítio Menino Jesus.

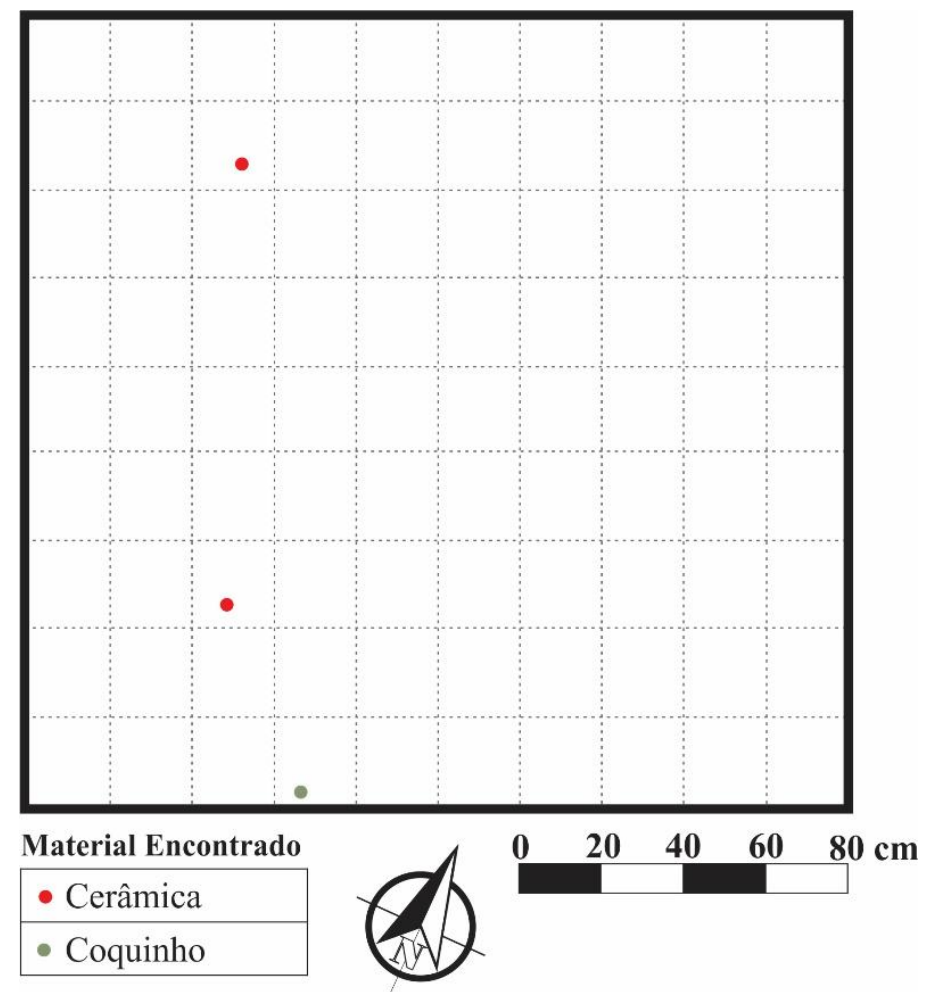

Fonte: Faccio, 2015

Figura 29 - Quadra A2 N1. Localização de vestígios arqueológicos na área de decapagem do Sítio Menino Jesus.

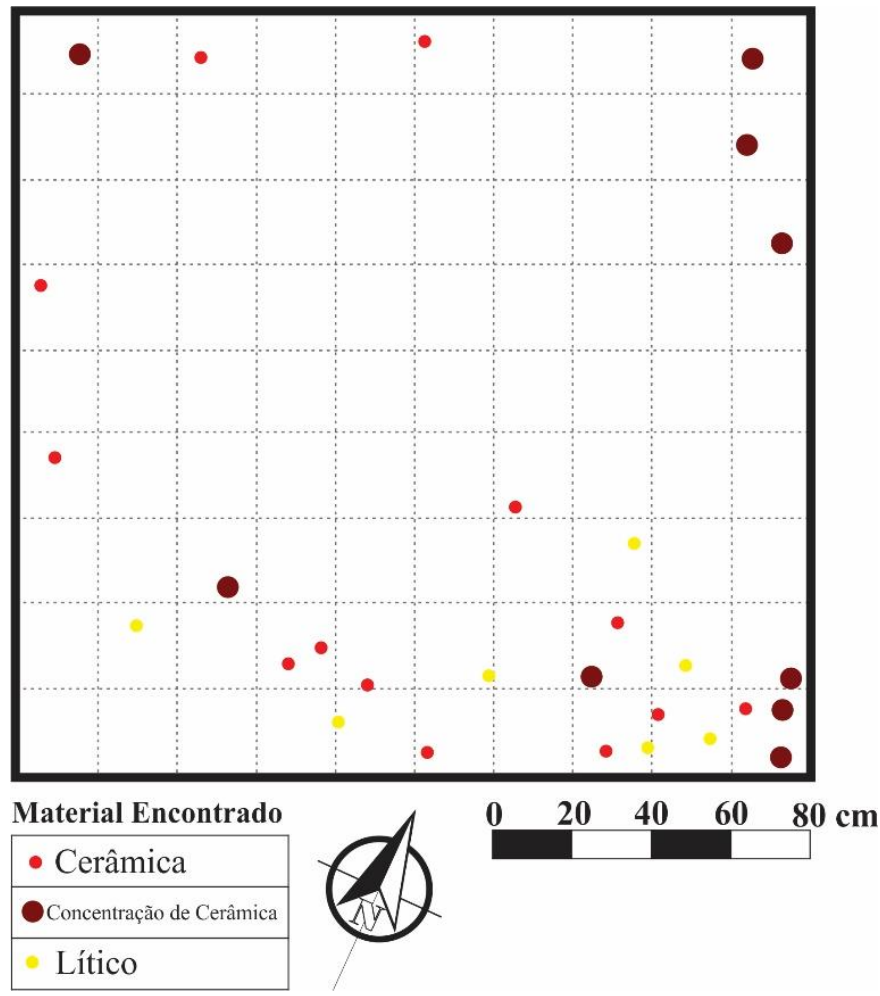

Fonte: Faccio, 2015 
Figura 30 - Quadra A2 N2. Localização de vestígios arqueológicos na área de decapagem do Sítio Menino Jesus.

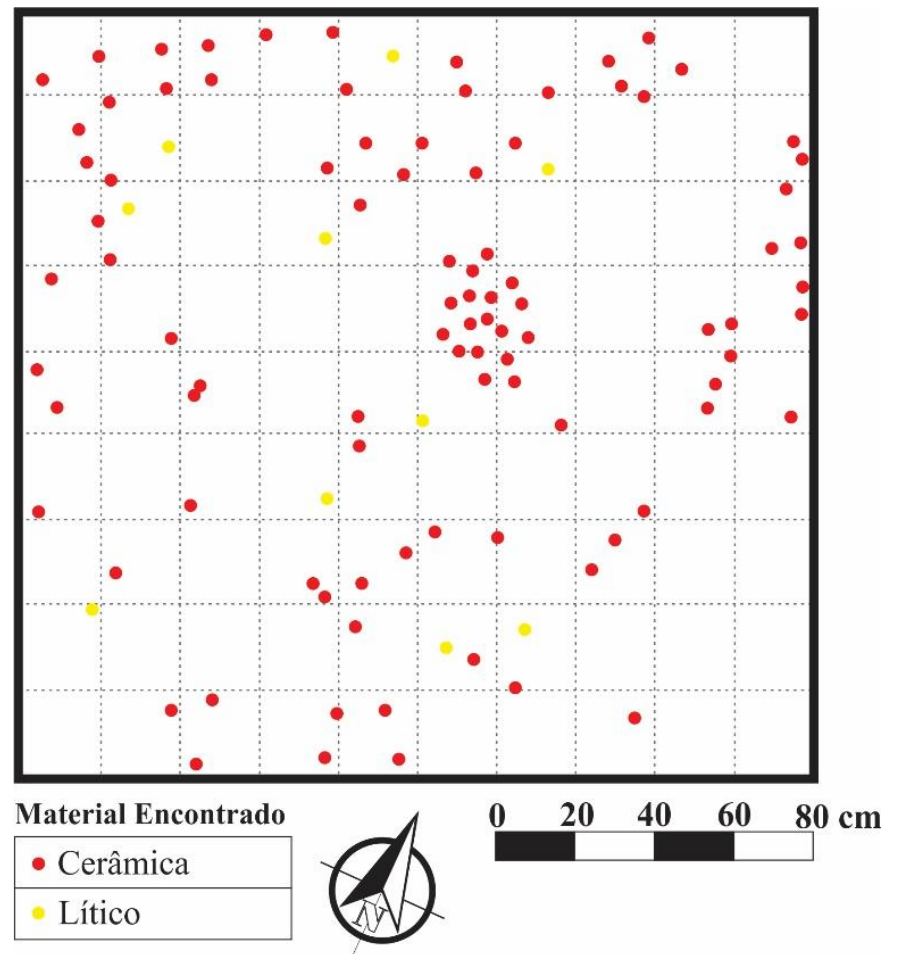

Fonte: Faccio, 2015

Figura 31 - Quadra B2 N1. Localização de vestígios arqueológicos na área de decapagem do Sítio Menino Jesus.

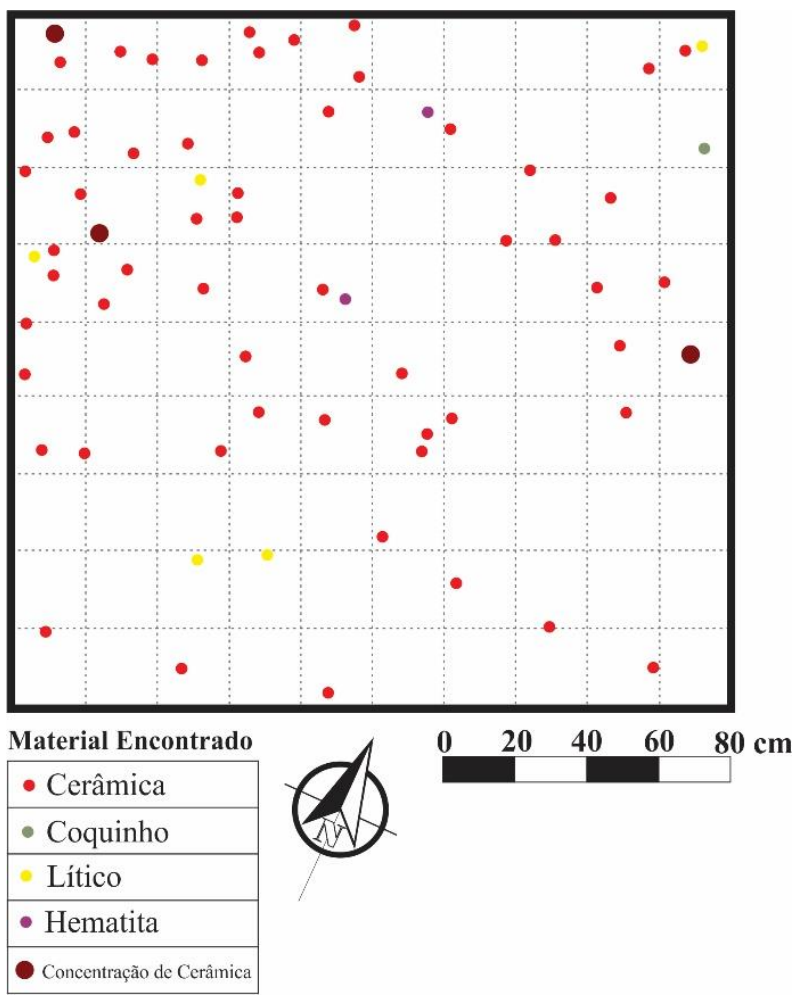

Fonte: Faccio, 2015 
Figura 32 - Quadra B2 N2. Localização de vestígios arqueológicos na área de decapagem do Sítio Menino Jesus.

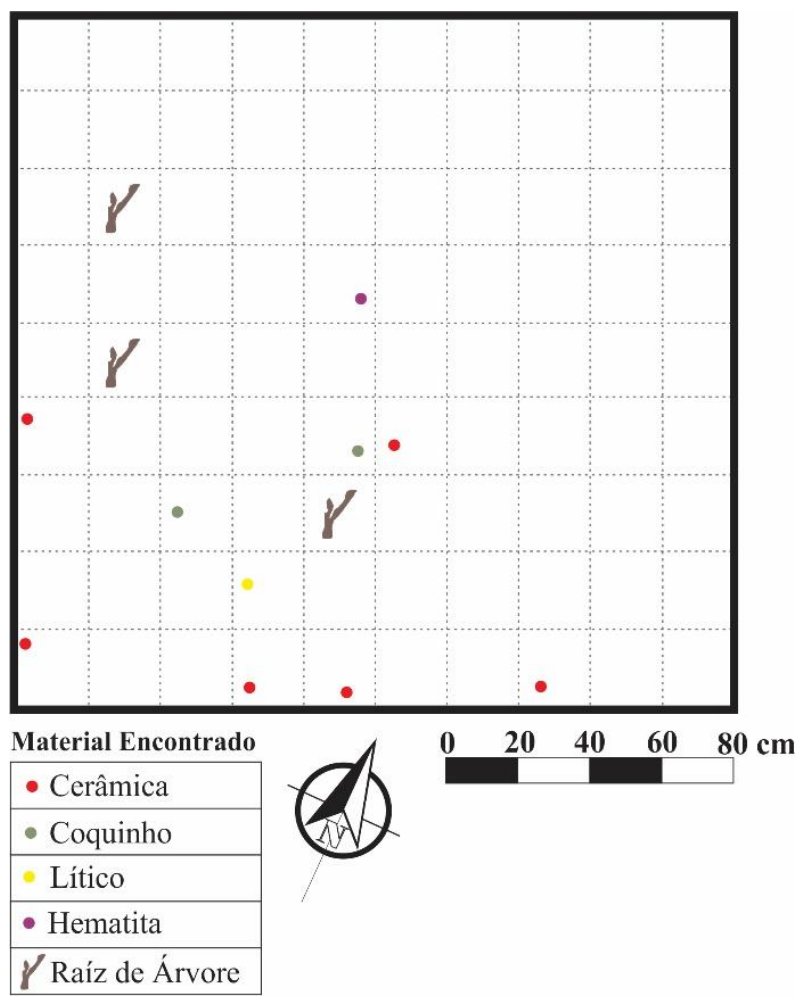

Fonte: Faccio, 2015

Figura 33 - Quadra C2 N1. Localização de vestígios arqueológicos na área de decapagem do Sítio Menino Jesus.

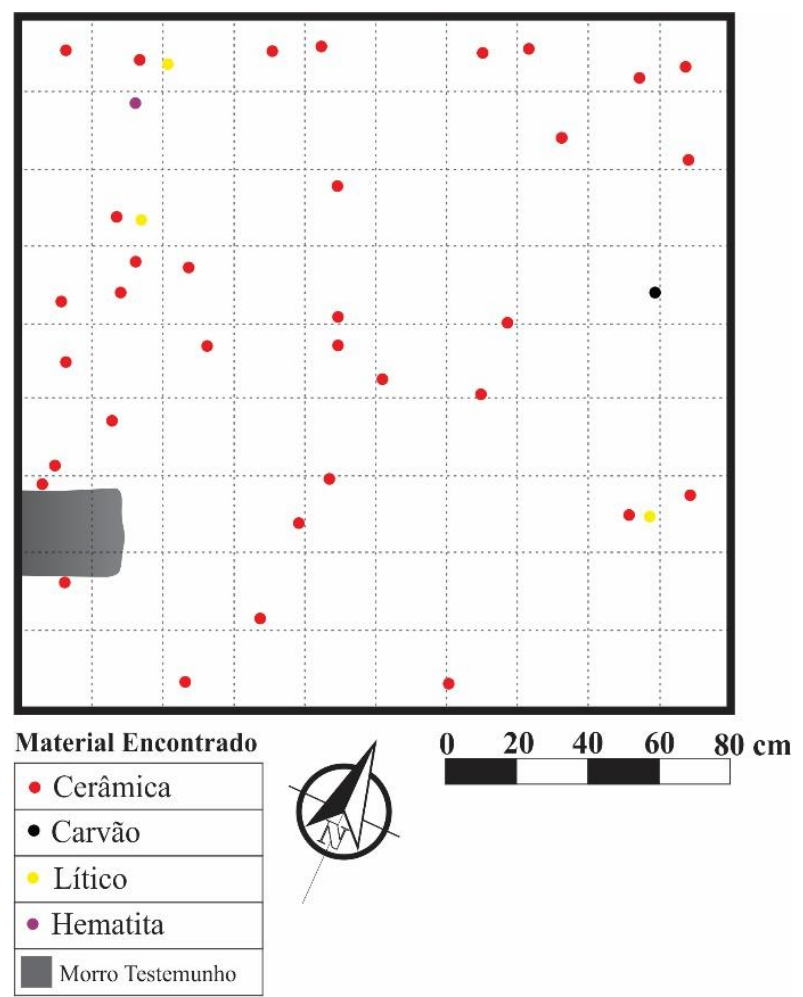

Fonte: Faccio, 2015 
Figura 34 - Quadra C2 N2. Localização de vestígios arqueológicos na área de decapagem do Sítio Menino Jesus.

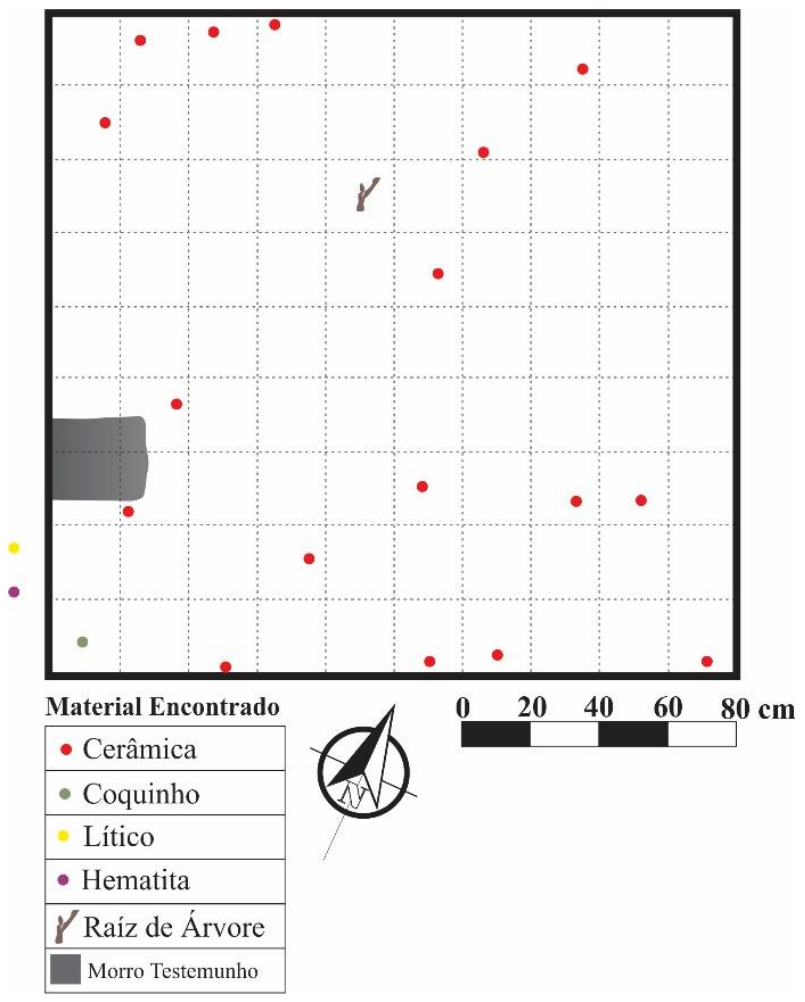

Fonte: Faccio, 2015 
Figura35- Quadras de decapagemnaáreade escavaçãodo sítio arqueológicoMeninoJesus.
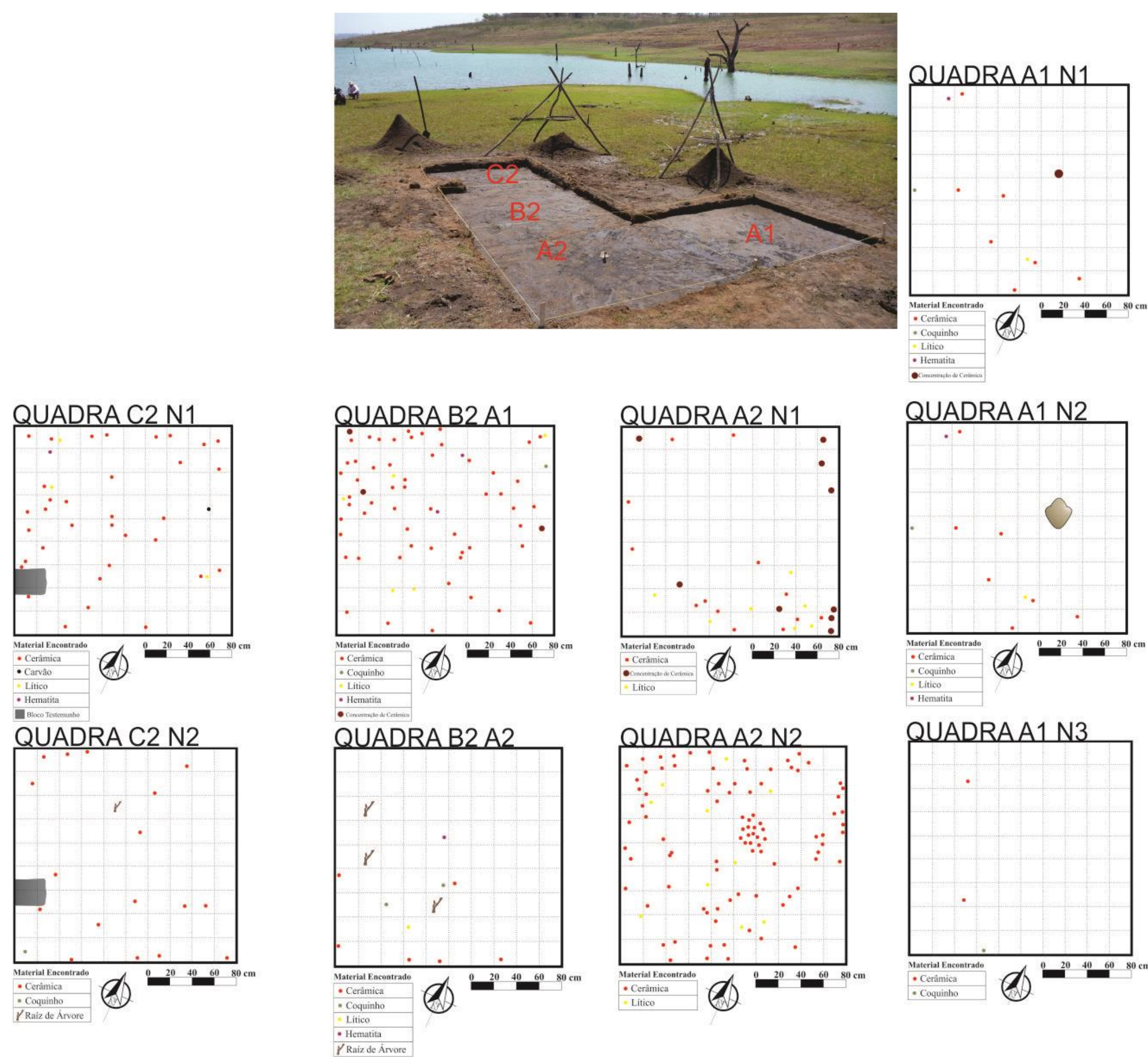

Fonte: Faccio,2015 
Figura 36 - Dispersão dos pontos de coleta na área do Sítio Arqueológico Menino Jesus durante os anos de 2013 e 2014.

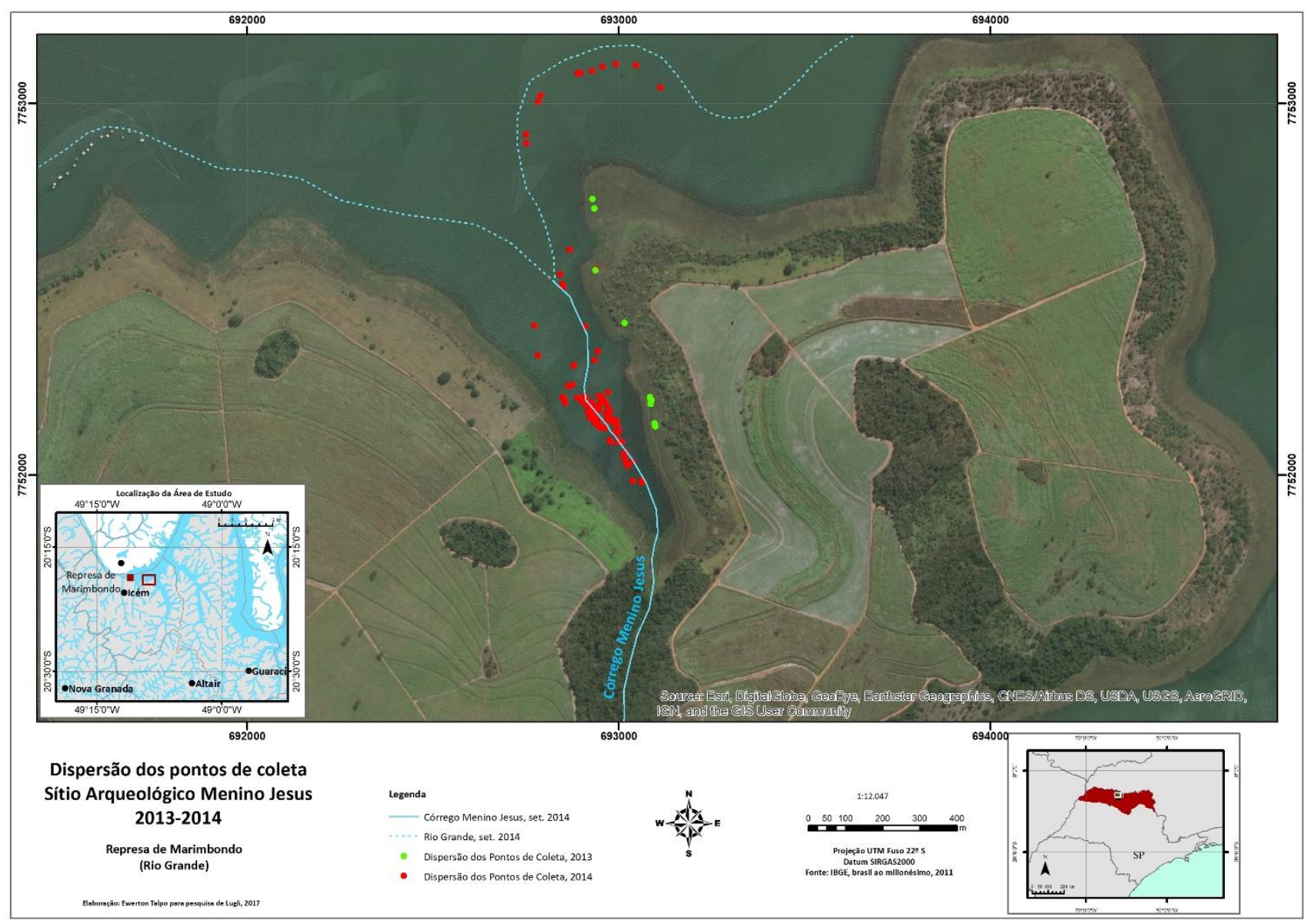

Fonte: Google Earth; IBGE. Confecção: Ewerton Talpo e David Pereira. 


\subsubsection{Quadro geoambiental e pós-deposicional}

Implantação do sítio na vertente: o sítio Menino Jesus encontra-se na intersecção entre a unidade de vertente do declive coluvial e fundo de vale, em elevação topográfica de 448 metros, implantado adjacente as duas margens do Córrego Menino Jesus, estendendo-se linearmente até a margem paulista do Rio Grande. Esta área encontra-se entre planícies baixas e colinas amplas, com topos extensos e aplainados e vertente com perfis retilíneos e convexos;

Caracterização geoambiental da vertente: A vertente apresenta efeito climático local caracterizado por meses de estiagem, como Junho, Julho e Agosto, com média de 16, $1 \mathrm{~mm}$ e meses de chuvas, como Dezembro e Janeiro, com média de 278,2mm. A direção predominante dos ventos é de SE e NE sendo responsáveis pela formação de ondas sobre o espelho d'água do reservatório da UHE-Marimbondo.

A vertente está inserida na Formação Vale do Rio do Peixe, apresentando pacote sedimentar pouco espesso (baixa vertente e fundo de vale) devido as características geomorfológicas agravadas pelo solapamento das margens do Córrego Menino Jesus. Este agravante ocorre por meio do processo erosivo das águas fluviais (área de depleção) e pluviais sobre o solo desnudado. Ocorre na margem direita do córrego afloramento de blocos de rochas básicas e cascalheira na margem direita do rio Grande. O solo é caracterizado pela classe Latossolo Vermelho formando grandes manchas sobre as rochas basálticas a areníticas, em colinas amplas e médias do vale do Rio Grande. O Latossolo Vermelho apresenta argilas predominantemente do tipo caulinita, revestidas por óxidos de ferro, responsáveis por sua coloração avermelhada. Quando encontrados em regiões quente e permanentemente úmidas, costumam embasar vegetação de densa floresta, com quantidade mínima de nutrientes, reciclados sazonalmente pela vegetação. Em regiões com longa estação seca, desenvolve-se vegetação pouco densa, como Cerrado e Cerradões (LEPSCH, 2002).

Vegetação remanescente: Levantamento florístico de algumas espécies no perímetro do sítio Menino Jesus e área de entorno foram realizados pela equipe de pesquisadores da FCT-UNESP e funcionário da Bunge-Moema durante o desenvolvimento deste trabalho. Este levantamento registrou a presença das espécies descritas na Tabela 7. 
Tabela 7 - Levantamento florístico na área do sítio Menino Jesus e de seu entorno.

\begin{tabular}{|c|c|c|c|c|}
\hline Nome Científico & Nome Popular & Nome indígena & Ocorrência & Possíveis Usos \\
\hline Ficus citrifolia & Figueira & - & Floresta Ombrófila & $\begin{array}{l}\text { Alimentação humana } \\
\text { (fruto) e lenha }\end{array}$ \\
\hline $\begin{array}{l}\text { Hymenaea } \\
\text { courbaril }\end{array}$ & Jatobá & Jata Yva (Guarani) & $\begin{array}{c}\text { Floresta Ombrófila Mista e } \\
\text { Floresta Estacional Semidecidual }\end{array}$ & $\begin{array}{l}\text { Alimentação humana } \\
\text { (fruto) e uso de sua } \\
\text { resina }\end{array}$ \\
\hline $\begin{array}{c}\text { Cecropia } \\
\text { Pachystachia }\end{array}$ & Embaúba & - & $\begin{array}{c}\text { Floresta Ombrófila Mista e } \\
\text { Floresta Estacional Semidecidual }\end{array}$ & $\begin{array}{l}\text { Atrativa para caça de } \\
\text { pássaros e bicho } \\
\text { preguiça }\end{array}$ \\
\hline $\begin{array}{l}\text { Myracrodruon } \\
\text { Urundeuva }\end{array}$ & Aroeira Preta & - & $\begin{array}{c}\text { Floresta Estacional Semidecidual } \\
\text { e Decidual }\end{array}$ & $\begin{array}{l}\text { Lenhosa, construção e } \\
\text { medicinal (sementes) }\end{array}$ \\
\hline $\begin{array}{l}\text { Senegalia } \\
\text { polyphylla }\end{array}$ & Monjoleiro & - & $\begin{array}{c}\text { Floresta Ombrófila Densa, } \\
\text { Floresta Estacional Semidecidual, } \\
\text { Decidual e Cerrado }\end{array}$ & $\begin{array}{l}\text { Construção, medicinal e } \\
\text { alimentação animal }\end{array}$ \\
\hline $\begin{array}{l}\text { Acrocomia } \\
\text { aculeata }\end{array}$ & Macaúba & $\begin{array}{l}\text { Roy rak (Krahô); } \\
\text { Kutó (Panará) }\end{array}$ & Floresta Estacional Semidecidual & $\begin{array}{c}\text { Construções, coberturas } \\
\text { (folhas), fibras têxteis, } \\
\text { alimentação (polpa e } \\
\text { óleo) }\end{array}$ \\
\hline Attalea Phalerata & Bacuri & Rõ tere (Krahô) & Floresta Estacional Semidecidual & $\begin{array}{l}\text { Construções, coberturas } \\
\text { (folhas), fibras têxteis, } \\
\text { alimentação (polpa, } \\
\text { amêndoas e palmito) }\end{array}$ \\
\hline
\end{tabular}

Fonte: Giraldin, 1997; Nascimento Et. Al. 2009; Ibflorestas.org. 
Agentes e Processos de transformação: O sítio arqueológico Menino Jesus e sua área de entorno estão situados em área de depleção e são intensamente afetados por intemperismo e bioturbação agravadas pelas ações antrópicas. Agentes químicos como umidade e insolação sazonais são constantes devido ao avanço e recuo das águas. O regime do fluxo pluvial, fluvial e eólico provocam meteorização física nos vestígios arqueológicos e ambiente de entorno por meio da desagregação mecânica. Meteorização biológica pode ocorrer por conta do mexilhão dourado que fixam-se nos fragmentos cerâmicos e líticos podendo desagregar camadas menos resistentes desses materiais e pela movimentação do gado que incide diretamente na quebra de material arqueológico e na erosão mecânica do solo.

As principais atividades antrópicas registradas nesta paisagem foram o preparo do solo, implicando, possivelmente, aração com aveica (inversão de uma camada de 40 a $45 \mathrm{~cm}$ de espessura) até a década de 1970. Após 1975 atividades antrópicas no local ficaram por conta da dinâmica do reservatório de água da UHE-Marimbondo e da criação de gado no entorno.

A área é afetada tanto pela dinâmica do declive coluvial, responsável pelo transporte de colúvio das áreas mais altas para as áreas mais baixas, quanto pela dinâmica do fundo de vale, responsável pela deposição aluvial e retrabalhamento das margens dos cursos de água. Acrescenta-se a esse fenômeno a complexidade do processo histórico de ocupação da região, responsável pelo desmatamento, preparo da terra para a lavoura, inundação por reservatório de água e pecuária. Os processos em apreço foram responsáveis por forte erosão laminar e linear, com perda de solo pelo escoamento pluvial, gerando assoreamento do córrego. Por outro lado, ocorre sazonalmente a subida e descida de água do reservatório, promovendo o solapamento das margens do córrego e rio, assim como, escavação da baixa - média vertente com o recuo das águas do reservatório.

Áreas de captação de matéria prima: foram detectadas em diversos microambientes fontes de matéria prima aptas a confecção de instrumentos e de consumo de água. Nesse ínterim, foram detectadas três fontes de argila (branca e preta), 10 nascentes próximas as concentrações de material arqueológico e uma grande cascalheira situada na margem direita do Rio Grande, próxima a confluência com o córrego Menino Jesus.

A plotagem dessas fontes de matéria prima são importantes para realizar correlações com os dados arqueológicos inseridos na paisagem.

Na Tabela 8 e Figura 34 podemos visualizar as três fontes de argila que foram mapeadas e coletadas (amostras para análise laboratorial). Todas as fontes de argila foram 
evidenciadas na margem esquerda do córrego Menino Jesus, bem como, às 10 nascentes levantadas. As cascalheiras foram identificadas na margem direita do Rio Grande, próxima a confluência com este córrego.

Tabela 8 - Georreferenciamento das Matérias Primas adjacentes ao Sítio Menino Jesus

\begin{tabular}{c|c}
\hline Matéria Prima & Localização UTM (m) 22k \\
\hline Depósito de Argila & 693.000 / 7.752.099 \\
\hline Depósito de Argila & 692.961 / 7.752.133 \\
\hline Depósito de Argila & 692.947 / 7.752.187 \\
\hline Afloramento de água (nascente) & 692.978 / 7.752.095 \\
\hline Afloramento de água (nascente) & 692.975 / 7.752.101 \\
\hline Afloramento de água (nascente) & 692.961 / 7.752.133 \\
\hline Afloramento de água (nascente) & 692.954 / 7.752.134 \\
\hline Afloramento de água (nascente) & 692.946 / 7.752.141 \\
\hline Afloramento de água (nascente) & 692.940 / 7.752.157 \\
\hline Afloramento de água (nascente) & 692.935 / 7.752.184 \\
\hline Afloramento de água (nascente) & 692.935 / 7.752.185 \\
\hline Afloramento de água (nascente) & 692.919 / 7.752.194 \\
\hline Afloramento de água (nascente) & 692.913 / 7.752.194 \\
\hline Cascalheira & 693.111 / 7.753.049 \\
\hline Cascalheira & 692.751 / 7.752.899
\end{tabular}

Fonte: Faccio, 2015 
Figura 37 - Localização de depósitos de argila, nascentes e cascalheira na área do Sítio Menino Jesus

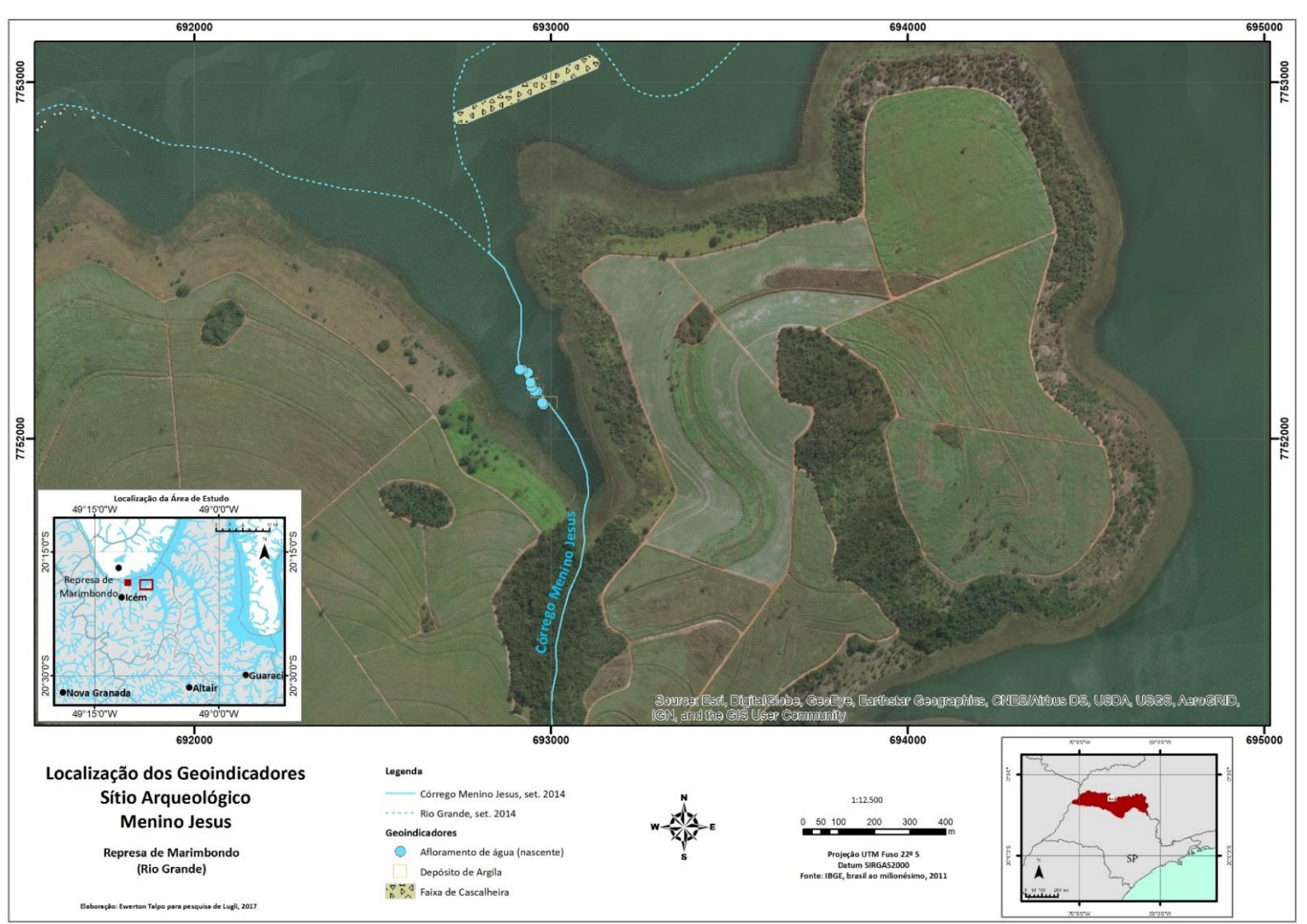

Fonte: Google Earth; IBGE. Confecção: Ewerton Talpo e David Pereira. 
Efeitos sobre o registro arqueológico: os principais efeitos sobre o registro arqueológico são: 1- processo de aragem do solo provocando deslocamentos verticais dos vestígios arqueológicos e redução dos mesmos; 2- exposição do material arqueológico a processos erosivos e intempéries de todas as ordens, sobretudo aquelas provocadas pelo regime pluvial e fluvial; 3- rearticulação ou transporte de vestígios arqueológicos situados no contato superior da faixa de depleção, com movimentações laterais e em direção a jusante com o recuo da água; 4- retrabalhamento das margens do córrego, com possíveis desmoronamentos, remobilizando os vestígios e estruturas arqueológicas para o leito do curso de água, responsável pelo transporte dos materiais. Os processos ocorrem de maneira conjunta, tornando-se complexo o impacto sobre o sítio.

\subsubsection{Análise da coleção arqueológica}

\section{Os líticos lascados}

No que se refere aos materiais líticos lascados, houve o resgate de 171 peças tanto em níveis superficiais como em níveis subsuperficiais. No trabalho de curadoria dos materiais coletados, foi possível identificar peças distribuídas entre lascas, com 44,4\% dos casos, núcleos, com 9,9\% dos casos, instrumentos, com 7,6\% dos casos, resíduos, com 3,5\% dos casos e matérias-primas em estado bruto, com 33,9\% dos casos (Tabela 9).

Tabela 9 - Frequência das categorias identificadas. Sítio Arqueológico Menino Jesus. Icém - SP.

\begin{tabular}{l|l|l}
\hline Categoria & Quantidade & $\mathbf{\%}$ \\
\hline Lasca & 76 & 44,4 \\
\hline Núcleo & 17 & 9,9 \\
\hline Resíduo & 6 & 3,5 \\
\hline Instrumento & 13 & 7,6 \\
\hline $\begin{array}{l}\text { Peças brutas sem traços de } \\
\text { lascamento }\end{array}$ & 55 & 33,9 \\
\hline Total & $\mathbf{1 7 1}$ & $\mathbf{1 0 0}$ \\
\hline
\end{tabular}

Fonte: Faccio, 2015 
No procedimento de curadoria foi possível identificar também as matériasprimas referentes aos materiais arqueológicos coletados (Tabela 10).

Tabela 10 - Frequência de matérias-primas identificadas. Sítio Arqueológico Menino Jesus. Icém - SP.

\begin{tabular}{l|l|l}
\hline Matéria - Prima & Quantidade & $\mathbf{\%}$ \\
\hline Silexito & 62 & 36,8 \\
\hline Quartzito & 36 & 21 \\
\hline Arenito Silicificado & 13 & 8,7 \\
\hline Basalto & 40 & 25,7 \\
\hline Quartzo & 6 & 3,5 \\
\hline Outros & 7 & 4,1 \\
\hline Total & $\mathbf{1 6 4}$ & $\mathbf{1 0 0}$ \\
\hline & Fonte: Faccio, 2015
\end{tabular}

A Tabela 10 apresenta a maior ocorrência da matéria-prima silexito tendo ela, ocorrido em $36 \%$ dos casos. O basalto foi a segunda matéria-prima mais recorrente com $25 \%$ dos casos. O quartzito também apresentou expressividade na coleção lítica com $21 \%$ de ocorrência. O Arenito Silicificado (8\%) e Quartzo (3\%) também foram identificados na coleção lítica. O item 'outros' apresenta materiais com intrusão de outras matériasprimas em sua composição, como por exemplo, o silexito com intrusão de quartzo e o quartzito com intrusão de mica.

Foi possível identificar os suportes de lascamento em uma quantidade expressiva de materiais conforme apresenta a Tabela 11.

Tabela 11 - Frequência de Suportes identificados. Sítio Arqueológico Menino Jesus. Icém - SP.

\begin{tabular}{l|l|l}
\hline Suporte & Quantidade & $\mathbf{\%}$ \\
\hline Seixo & 72 & 42,6 \\
\hline Plaqueta & 4 & 2,3 \\
\hline Nódulo & 17 & 9,9 \\
\hline Bloco & 34 & 22,2 \\
\hline Cristal & 5 & 2,9 \\
\hline N/I & 32 & 19,2 \\
\hline Total & $\mathbf{1 6 4}$ & $\mathbf{1 0 0}$ \\
\hline
\end{tabular}

Fonte: Faccio, 2015 
Conforme é apresentado na Tabela 9 é possível verificar, uma quantidade expressiva do suporte 'seixo'. Esta variedade de material ocorreu na coleção lítica, em $42 \%$ dos casos. O suporte 'bloco' ocorre em $22 \%$ dos casos seguidos dos suportes 'nódulo' (10\%), 'cristal' (3\%) e 'plaqueta' (2\%). Em 19\% dos casos não foi possível identificar os suportes de lascamento.

Nota-se que o suporte seixo, utilizado em 42,6\% da produção lítica, está diretamente associado a área de cascalheira identificada à margem do rio Grande. Este fato é um importante dado a respeito do mapeamento das áreas de captação de recursos naturais.

Os Líticos Polidos

Em relação aos materiais líticos polidos foram identificadas 13 peças com traços claros de trabalho de polimento. Nesses casos, as peças foram classificadas de acordo com as principais características presentes em cada material. Diante destas condições, identificamos, na etapa de curadoria, oito instrumentos sendo seis calibradores de sulco, uma mão de pilão fragmentada e um fragmento de lâmina de machado. Outros materiais apresentam sinais de trabalho de polimento, como blocos de basalto com depressões ou desgastes pouco profundos em seu centro, sugerindo tratar-se de quebra-coquinhos.

Foi possível verificar que a matéria-prima predominante para uso dos materiais polidos foi o quartzito (calibradores de sulco) seguido do basalto (lamina de machado e possivelmente quebra coquinhos). No caso do quartzito houve a ocorrência de sete casos e o basalto em seis casos. Outras matérias-primas como o granito (mão de pilão) e o arenito silicificado (calibrador de sulco) também apareceram na coleção de líticos polidos.

Os fragmentos de cerâmica

No Sítio Menino Jesus foram resgatados 3130 fragmentos de cerâmica nas categorias borda, parede, parede angular, suporte para tampa, disco de fuso e forma dupla (Tabela 12). As paredes foram predominantes na classificação dos fragmentos cerâmicos analisados (com 90,8\% dos casos), seguidas dos fragmentos de borda (com 8,06\% dos casos), base (com $0,6 \%$ dos casos) e parede angular (com $0,5 \%$ dos casos). O número reduzido de bases apresentadas deve-se, em parte, ao estado de fragmentação das peças, 
ocasionados por processos pós-deposicionais como desmatamento, aragem, pecuária e erosões fluviais e pluviais.

Tabela 12 - Categorias dos fragmentos cerâmicos do Sítio Arqueológico Menino Jesus.

\begin{tabular}{ccc}
\hline Categoria & Quantidade de peças & \% \\
\hline Borda $^{71}$ & 257 & 8,02 \\
\hline Parede $^{72}$ & 2832 & 90,8 \\
\hline Parede Angular & 15 & 0,5 \\
\hline Base & 20 & 0,6 \\
\hline Suporte para Tampa & 1 & 0,04 \\
\hline Não Identificado & 2 & 0.06 \\
\hline Disco de Fuso & 1 & 0.04 \\
\hline Forma Dupla & 2 & 0.08 \\
\hline Total & $\mathbf{3 1 3 0}$ & $\mathbf{1 0 0}$
\end{tabular}

Fonte: Faccio, 2015

Concomitante à análise dos fragmentos cerâmicos foi realizada a formação de conjuntos de fragmentos do mesmo pote. Formaram-se apenas seis conjuntos de um total de 3130 fragmentos de cerâmica. O conjunto 1 foi recuperado durante as decapagens subsuperficiais da Quadra A1 em seu segundo nível. Os fragmentos deste conjunto foram reconstituídos usando técnica própria do $\mathrm{LAG}^{73}$, se apresentando como parte de um vaso esférico ovaloide com altura de 30cm e largura de $40 \mathrm{~cm}$ (Fotos 30 e 31). Como parte da base do antigo vaso não foi reconstituída, acreditamos que o recipiente possuía altura superior a identificada. $\mathrm{O}$ vaso em apreço tem forma, altura e diâmetro semelhantes aos da Tradição Aratu-Sapucaí, estudadas por Wust (1983) no Mato Grosso do Sul e Goiás. Os demais conjuntos apresentaram-se com poucas peças (variando entre dois ou três fragmentos) e foram encontrados no mesmo ponto de coleta, evidenciando que, nesses casos, os processos pós-deposicionais não afastaram os fragmentos do mesmo pote.

\footnotetext{
${ }^{71}$ Um fragmento de borda possui furo de suspensão.

${ }^{72} \mathrm{Um}$ fragmento de parede possui furo de suspensão.

${ }^{73}$ Laboratório de Arqueologia Guarani, FCT-UNESP. Coordenadora Profa. Dra. Neide Barrocá Faccio.
} 
Fotos 30 e 31 - Reconstituição do conjunto 1. Vaso esférico ovaloide. Sítio Arqueológico Menino Jesus, município de Icém, SP.
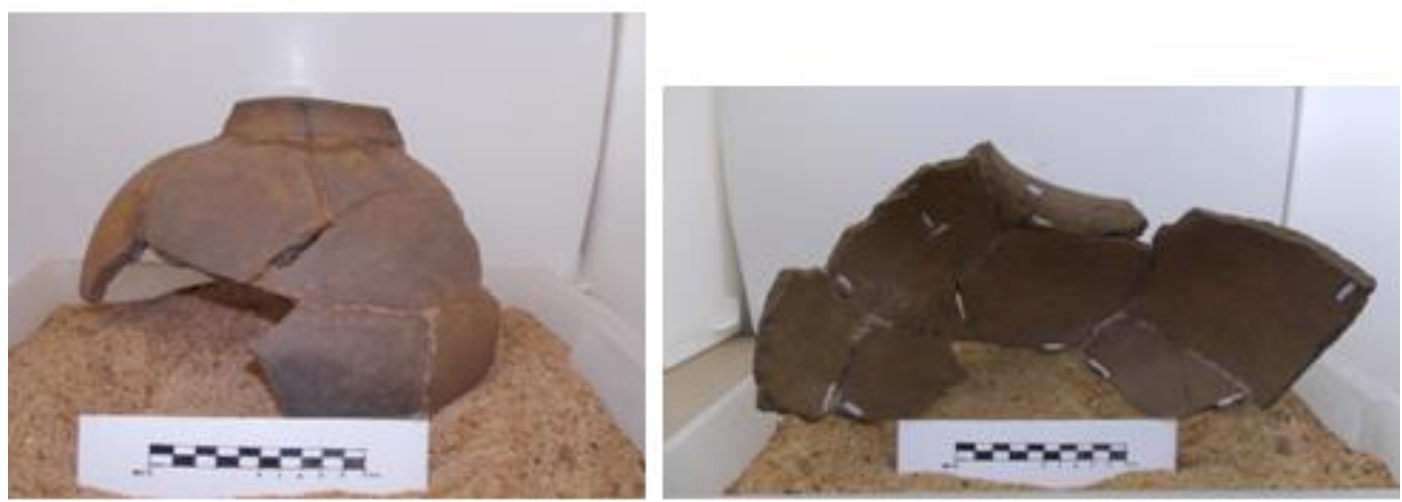

Fonte: Faccio, 2015

O disco de fuso encontrado apresentou forma circular e provavelmente foi modelado em forma de roda e seu orifício confeccionado com a argila ainda em estado plástico. Também foram coletados dois fragmentos de formas duplas ou conjugadas atribuídas tipicamente à Tradição Aratu-Sapucaí nos estados do Centro-Oeste e Norte de São Paulo (FERNANDES, 2001; OLIVEIRA; FACCIO; LUZ, 2013; WUST, 1983).

Fotos 32 e 33: Fragmento de fuso de cerâmica do Sítio Arqueológico Menino Jesus, Município de Icém, SP.
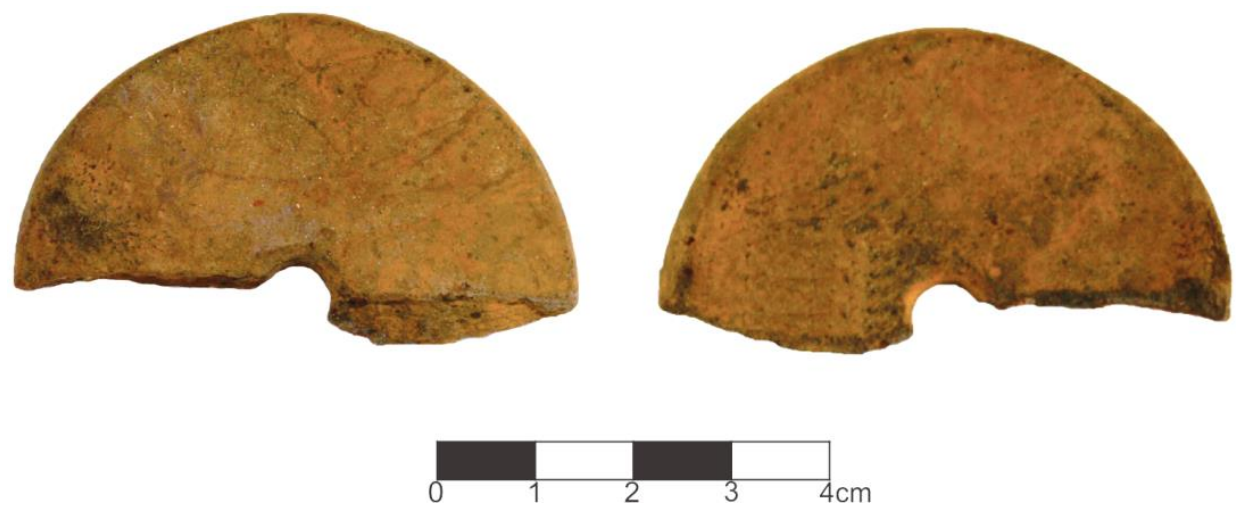

Fonte: Faccio, 2015 
Figuras 38 e 39 - Reconstituição de cerâmica do Sítio Arqueológico Menino Jesus, Município de Icém, SP.

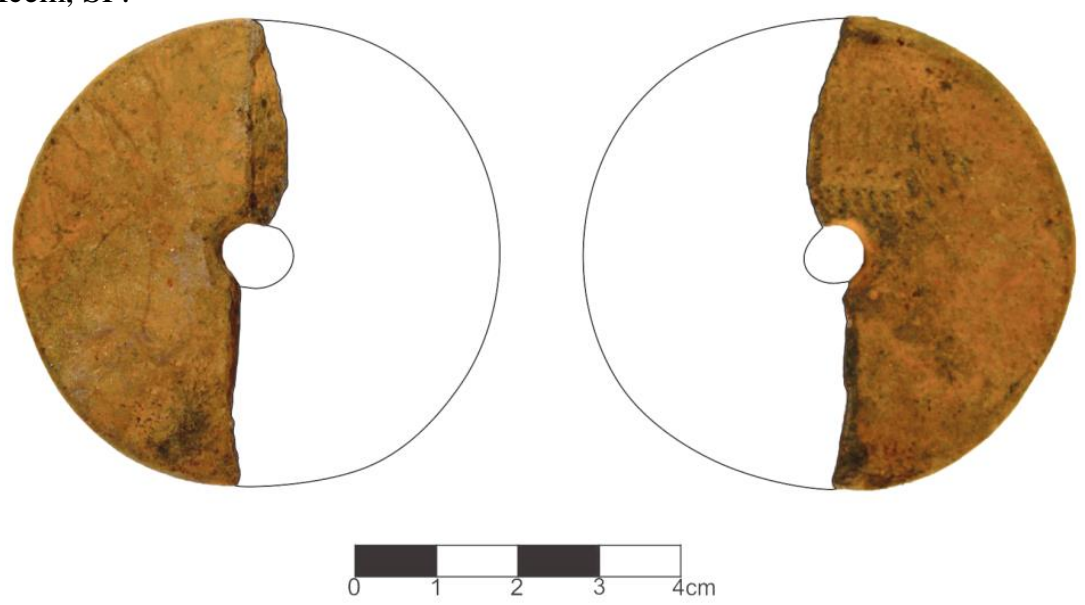

Fonte: Faccio, 2015

Fotos 34 e 35 - Bordas cerâmica de vasilha dupla e borda com incisão do Sítio Arqueológico Menino Jesus, Município de Icém, SP.
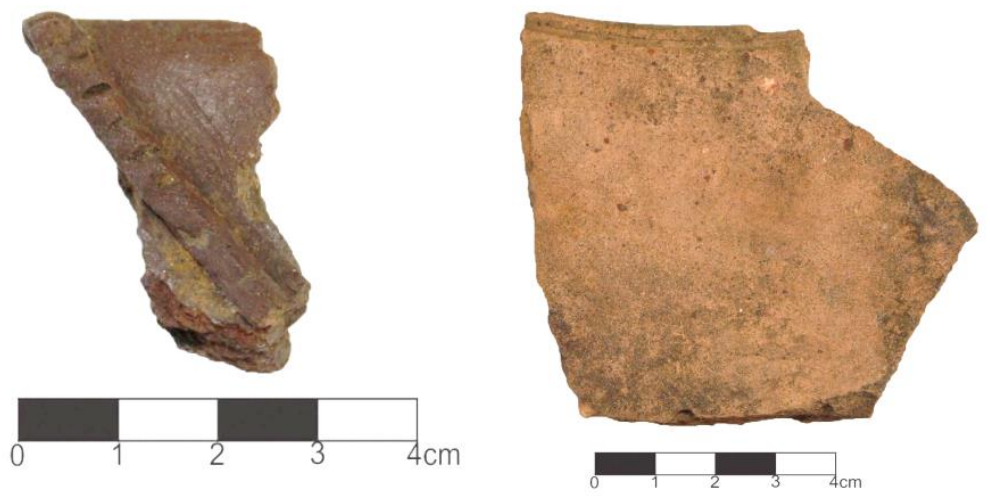

Fonte: Faccio, 2015

A Tabela 13 apresenta os tipos de antiplástico e/ou tempero usados. A frequência do antiplástico e/ou tempero mineral/hematita foi de $74,5 \%$ dos casos, enquanto a do mineral foi de $22,73 \%$ dos casos e a do mineral/hematita/caulim foi de $2,46 \%$ dos casos. Esses números indicam que tanto os minerais como a hematita e a caulinita foram empregados ou estavam presentes naturalmente na massa de argila.

Tabela 13 - Tipos de Antiplástico do Sítio Arqueológico Menino Jesus.

\begin{tabular}{lcc} 
Antiplástico/Tempero $^{74}$ & $\begin{array}{c}\text { Quantidade de } \\
\text { Peças }\end{array}$ & $\%$ \\
\hline
\end{tabular}

\footnotetext{
74 Em quatro casos filamentos paralelos na cor cinza foram identificados nas pastas das cerâmicas, necessitando de um aumento de 40 vezes na lente microscópica para sua visualização. A textura dessas pastas se apresentou porosa e leve, semelhantes às pastas identificadas com tempero cariapé (WUST, 1983). Para a comprovação ou refutação dessa hipótese, esses fragmentos serão analisados por técnicas arqueométricas como a MEV ou a DFRX.
} 


\begin{tabular}{ccc}
\hline Mineral/Hematita & 2332 & 74,50 \\
\hline Mineral $^{75}$ & 711 & 22,73 \\
\hline Mineral/Hematita/Caulinita $_{\text {Mineral/Carvão }}$ & 77 & 2,46 \\
\hline Total & 10 & 0,31 \\
\hline
\end{tabular}

Fonte: Faccio, 2015

Os termos empregados para definir tipos de antiplástico/tempero como hematita e caulinita devem ser comprovados por meio das técnicas arqueométricas como a MEV ou a DFRX. Salientamos que possíveis blocos de hematita foram coletados nas quadras de decapagem e podem estar associados aos demais materiais arqueológicos. A relação de proximidade espacial dessa matéria-prima com os fragmentos cerâmicos é um fator a ser considerado nas análises intrassítio e mineralógica dos artefatos.

A caulinita encontrada na pasta de fragmentos de cerâmica pode estar associada aos depósitos de argila na cor branca (caulim). Técnicas modernas de fabricação de cerâmica fina recorrem ao caulim como matéria-prima indispensável (GUERRA, 1993). No passado essas fontes podem ter sido amplamente procuradas e utilizadas para a confecção da cerâmica e do engobo branco.

A Tabela 14 apresenta o tratamento de superfície do lado interno e externo dos fragmentos cerâmicos. Alguns fragmentos com tratamento de superfície inciso, marcado por cestaria, furo de suspensão, engobo ou pintura foram registrados.

Tabela 14 - Tratamento de superfície dos fragmentos cerâmicos do Sítio Arqueológico Menino Jesus.

\begin{tabular}{ccc}
\hline Tipo Interno/Externo & $\begin{array}{c}\text { Quantidade de } \\
\text { Peças }\end{array}$ & \% \\
\hline Liso/Liso & 3032 & 96,89 \\
\hline $\begin{array}{c}\text { Liso/Engobo Branco com pintura } \\
\text { vermelha }\end{array}$ & 3 & 0,09 \\
\hline Liso/Inciso & 21 & 0,67 \\
\hline Liso/Engobo Vermelho & 1 & 0,03 \\
\hline Liso/Engobo Branco & 24 & 0,78 \\
\hline Inciso/Inciso & 3 & 0,09 \\
\hline Liso/Inciso no Lábio & 2 & 0,06 \\
\hline Liso/Não Identificado & 2 & 0,06 \\
\hline
\end{tabular}

${ }^{75}$ Predominantemente formado por areia fina com grãos angulosos ou arredondados. Em alguns casos apresentou grãos angulosos de quartzo de 0,4 a $10 \mathrm{~mm}$. 


\begin{tabular}{ccc}
\hline Liso/Pintura vermelha & 2 & 0,06 \\
\hline Engobo Vermelho/Liso & 1 & 0,03 \\
\hline Engobo Branco/Liso & 22 & 0,72 \\
\hline Pintura/Pintura & 1 & 0,03 \\
\hline Engobo Branco e Vermelho/Liso & 1 & 0,03 \\
\hline Liso/Ungulado & 1 & 0,03 \\
\hline Liso/Pintado & 3 & 0,09 \\
\hline Liso/Serrungulado & 1 & 0,03 \\
\hline Inciso/Liso & 5 & 0,16 \\
\hline Marca de Cestaria/Inciso no Lábio & 1 & 0,03 \\
\hline Pintura/Liso & 1 & 0,03 \\
\hline Furo de suspensão/Furo de suspensão & 3 & 0,09 \\
\hline Total & $\mathbf{3 1 3 0}$ & $\mathbf{1 0 0 , 0 0}$ \\
\hline
\end{tabular}

Fonte: Faccio, 2015

A leitura dos dados mostra que $96,89 \%$ dos fragmentos cerâmicos foram apenas alisados em suas faces interna e externa. $\mathrm{O}$ alisamento interno com engobo branco externo esteve presente em $0,74 \%$ dos casos e o engobo branco interno e alisamento externo em $0,72 \%$ dos casos. Foram identificados dez fragmentos cerâmicos com pintura $(0,3 \%$ dos casos) tendo nove deles pinturas na face externa e um deles com pintura na face interna (Fotos 36, 37, 38 e 39 - Figuras 40, 41, 42, 43, 44, 45, 46 e 47).

Foto 36 e Figuras 40 e 41 - Reconstituição de decoração pintada, presente em fragmento de cerâmica. Sítio Arqueológico Menino Jesus, município de Icém, SP.
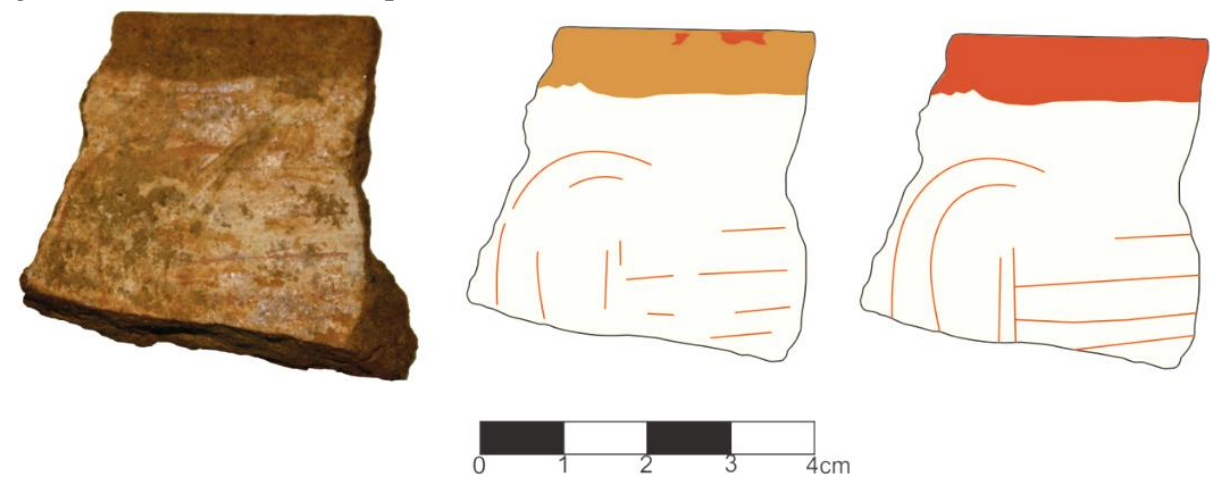

Fonte: Faccio, 2015 
Foto 37 e Figuras 42 e 43 - Reconstituição de decoração pintada, presente em fragmento de cerâmica. Sítio Arqueológico Menino Jesus, município de Icém, SP.
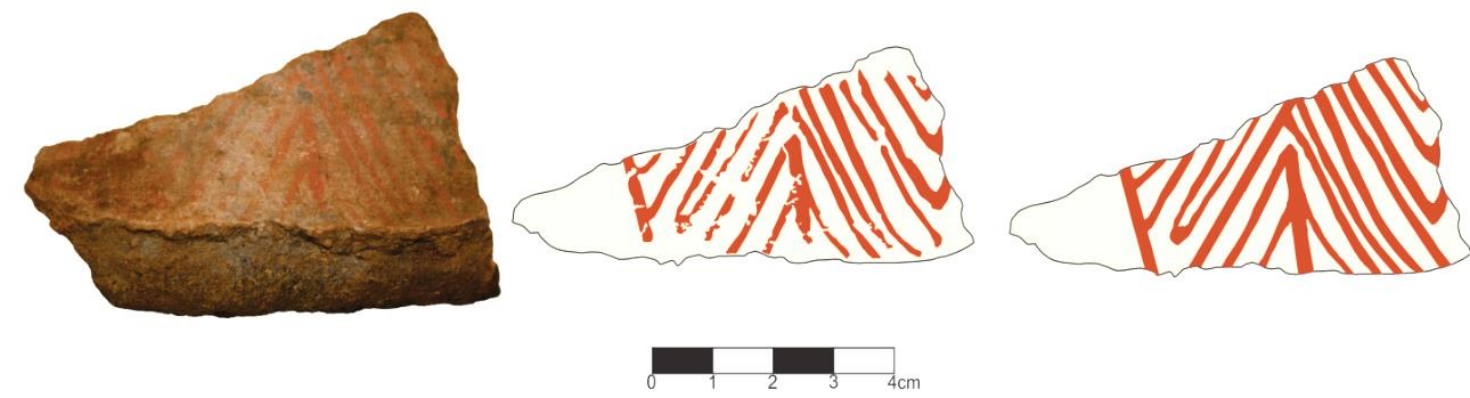

Fonte: Faccio, 2015

Foto 38 e Figuras 44 e 45 - Reconstituição de decoração pintada, presente em fragmento de cerâmica. Sítio Arqueológico Menino Jesus, município de Icém, SP.
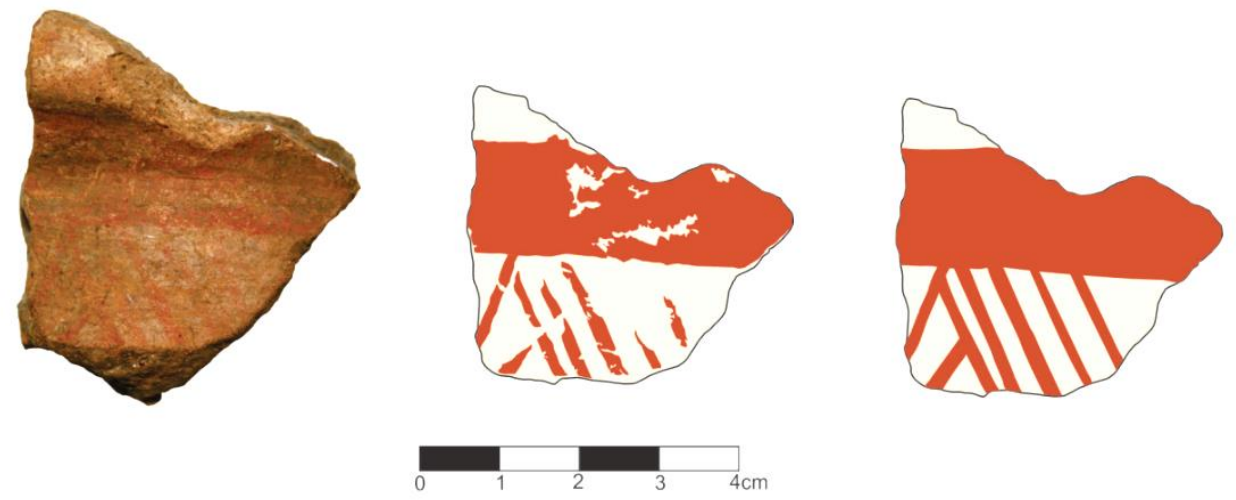

Fonte: Faccio, 2015

Foto 39 e Figuras 46 e 47 - Reconstituição de decoração pintada, presente em fragmento de cerâmica. Sítio Arqueológico Menino Jesus, município de Icém, SP.
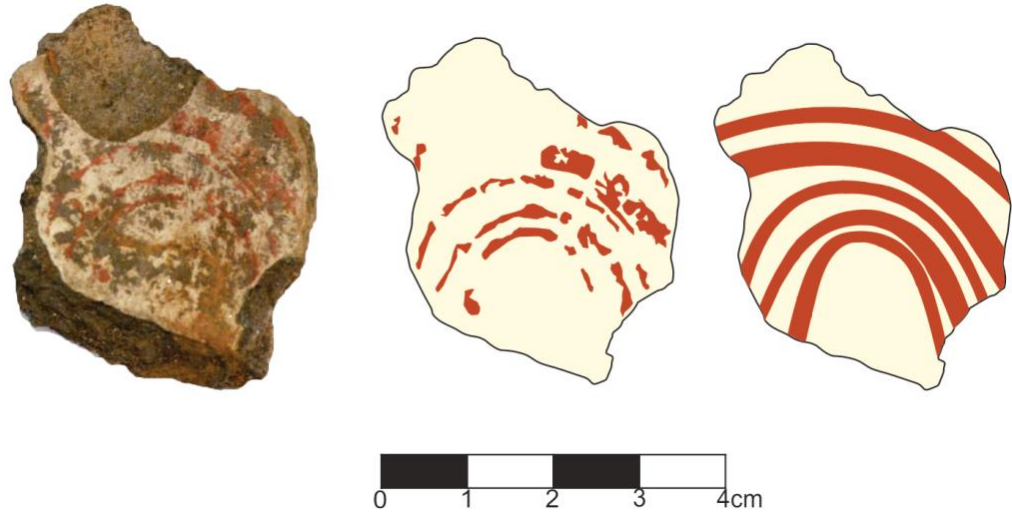

Fonte: Faccio, 2015

Se somarmos a porcentagem de todos os fragmentos com engobo e/ou pintura característicos da Tradição Tupiguarani teremos um universo de 1,85\% dos casos. Os dados obtidos para a pasta desses fragmentos devem ser confrontados com as fontes de argilas locais. Essa análise nos possibilitará inferir se esse material foi produzido com os 
recursos locais ou trata-se de produção extra-local, jogando novas luzes sobre os processos de trocas e interações culturais.

Das 257 bordas analisadas, apenas 36 apresentaram condições seguras para a reconstrução gráfica. As 36 reconstituições de bordas foram agrupadas em conjuntos que se aproximam das características morfológicas dos recipientes cerâmicos. Como ainda não foi feito nenhum catálogo de recipientes cerâmicos inteiros sobre a Tradição AratuSapucaí no Norte do estado de São Paulo, as reconstituições parciais se limitaram apenas às bordas mensuráveis.

O agrupamento em conjunto considerou os trabalhos de Wust (1983) sobre a Tradição Cerâmica Aratu-Sapucaí nos estados do Mato Grosso do Sul e Goiás, sendo realizadas as adaptações necessárias para nosso contexto de pesquisa.

O conjunto 1 agrupou as categorias de formas reconstituídas 1, 2 e 3 dos trabalhos de Wust (1983). Apresenta como características principais: (1) possuir corpo esférico e ovaloide e (2) diâmetro da borda de 6 a $66 \mathrm{~cm}$.

O conjunto 2 agrupou as categorias de formas reconstituídas 4, 5, 6 e 7 dos trabalhos de Wust (1983). Apresenta como características principais: (1) possuir corpo semiesférico e (2) diâmetro da borda de 6 a 60 cm.

O conjunto 3 agrupou as categorias de formas reconstituídas 12, 13 e 14 dos trabalhos de Wust (1983). Apresenta como características principais: (1) possuir corpo semiesférico e esférico com ponto de inflexão e (2) diâmetro da borda de 6 a $48 \mathrm{~cm}$.

O conjunto 4 agrupou as categorias de formas reconstituídas 15 e 16 dos trabalhos de Wust (1983). Apresenta como características principais: (1) possuir corpo semiesférico com ponto de inflexão e (2) diâmetro da borda de 6 a 54 cm.

O conjunto 5 coincide com a categoria de forma reconstituída 17 dos trabalhos de Wust (1983). Apresenta como características principais: (1) possuir corpo semiesférico com ponto angular e (2) diâmetro da borda de $12 \mathrm{a} 18 \mathrm{~cm}$.

O conjunto 6 agrupou as categorias de formas reconstituídas 9, 10 e 11 dos trabalhos de Wust (1983). Apresenta como características principais: (1) possuir corpo esférico e ovaloide com ponto de inflexão e (2) diâmetro da borda de 16 a $61 \mathrm{~cm}$.

Os fragmentos de bordas reconstituídos também foram plotados em mapa de dispersão intentando localizar possíveis áreas funcionais.

A reconstituição gráfica da forma das vasilhas, a partir dos fragmentos de bordas recuperados, pode ser visualizada abaixo: 
Figura 48 - Conjuntos dos fragmentos de bordas reconstituídas do sítio arqueológico Menino Jesus

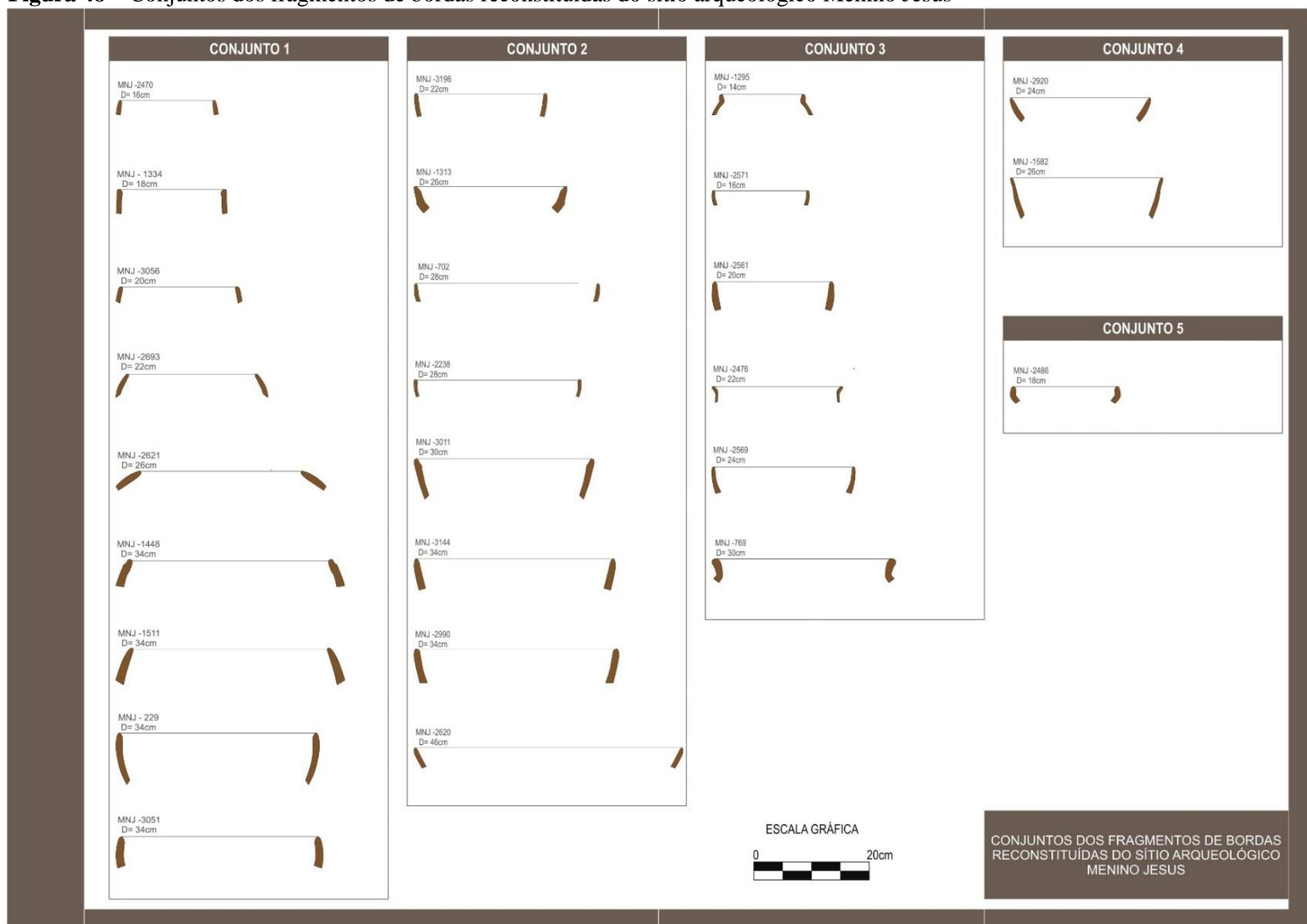

Confecção: Maria Frizarin e David Pereira. 


\subsubsection{Os materiais arqueológicos e a análise intrassítio}

As análises tecnotipológicas e espaciais desenvolvidas nos trazem informações sobre a ocupação e as formas de interação e atividades do espaço interno do sítio Menino Jesus. O detalhamento da pesquisa do sítio em tela produz informações sobre seus espaços internos, por meio da plotagem e da distribuição dos conjuntos de artefatos ali existentes, avançando assim, para questões mais amplas como as relacionadas aos aspectos de organizações e possíveis redes de atividades exercidas com outros grupos vizinhos.

Os conjuntos de materiais arqueológicos detectados, coletados e georreferenciados no sítio são provenientes de recipientes ou utensílios cerâmicos, instrumentos líticos lascados e polidos.

No Figura 48 podemos visualizar a dispersão dos fragmentos de cerâmica do Sítio Arqueológico Menino Jesus. Primeiramente, nota-se uma distribuição de material arqueológico nas duas margens do córrego. Esta distribuição, no lado direito do córrego supracitado, estende-se até a margem do Rio Grande. A configuração geral do depósito dos fragmentos de cerâmica forma linhas paralelas nas duas margens do córrego por quase um quilometro de extensão.

Nota-se, também, que essa ocupação apresenta pelo menos duas áreas de concentração de cerâmica quase contíguas. Ambas situam-se na margem esquerda do córrego. A ocupação humana pretérita nesta margem ocorreu sobre vertente com declive menos acentuado se comparada às da margem direita, o que possibilitaria uma área mais favorável para ocupação permanente e para o plantio. Por situar-se na face Oeste, a vertente da margem esquerda receberia insolação direta durante a parte da manhã, possibilitando clima mais ameno as pessoas e uma possível área de plantio.

As duas áreas de concentração foram selecionadas para serem escavadas, sendo denominadas de área de escavação 1 (Quadras A1, A2, B2 e C2) e área de escavação 2 (Quadras L4, M3 e M4). Os fragmentos cerâmicos coletados na área de escavação 1, incluindo a reconstituição parcial de um vaso cerâmico esférico ovaloide, nos permite inferir que tratava-se de uma área de atividade importante, provavelmente uma habitação ou fundo de habitação onde tarefas diárias ocorriam. Essa afirmação também é apoiada na dispersão dos conjuntos de fragmentos de bordas reconstituídos para esse sítio (Figura 49). Exceto o conjunto 2, os demais conjuntos concentraram-se na área das quadras 
supracitadas, mostrando que atividades relacionadas ao preparo e consumo de alimentos aconteciam nesse local.

Ressalta-se que próximo a esta área encontram-se diversos afloramentos de água e depósitos de argila (todos localizados na margem esquerda do córrego) que possibilitariam a coleta de matéria-prima para a produção de cerâmica e o acesso a água limpa e fresca.

Nas demais áreas deposicionais não foram registradas concentrações importantes de fragmentos cerâmicos. No entanto, por sua distribuição linear junto ao corpo de água, acreditamos que haveria uma dinâmica importante de atividades nas duas margens que deixaram suas marcas no depósito arqueológico. Ressalva-se também que movimentos de expansão e contração da aldeia podem ter deixado marcas de tempos distintos nesta paisagem. Essa constatação pode também fundamentar-se na presença de fragmentos cerâmicos tipicamente filiados a tradição tupiguarani, como é o caso dos fragmentos pintados e /ou apresentando engobo. Estes se apresentaram em quase $2 \%$ dos casos e podem ser testemunhos de reocupações de grupos humanos distintos àqueles filiados a tradições relacionadas a grupos Jê advindos do centro-oeste do país ou pertencerem a materiais inseridos em redes de trocas regionais. 
Figura 49 - Mapa de dispersão dos fragmentos de cerâmica do Sítio Arqueológico Menino Jesus.

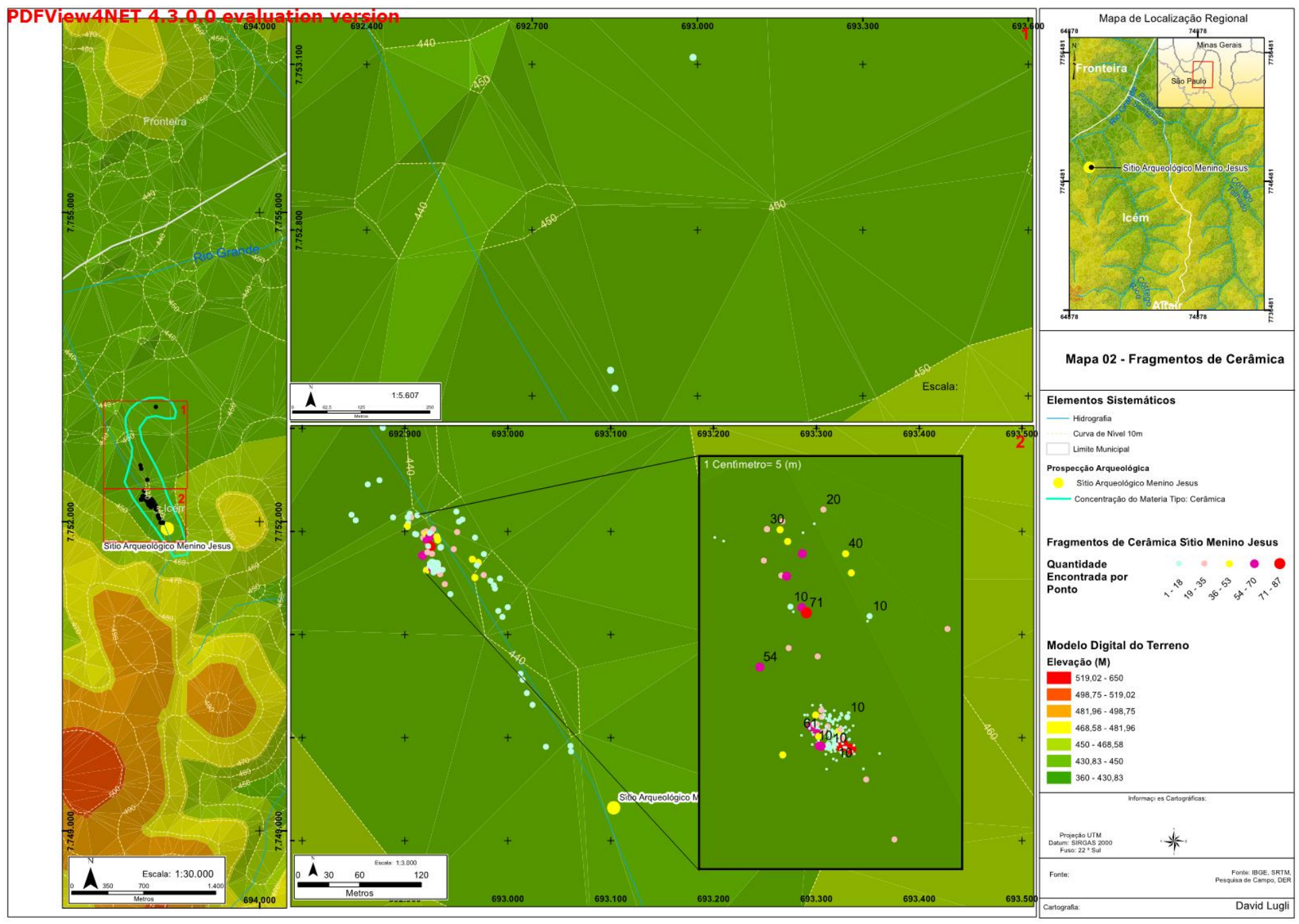

Fonte: IBGE e Google Earth. Confecção - Tadeu Gasparetto e David Pereira. 
Figura 50 - Mapa de dispersão dos fragmentos de bordas reconstituídas do Sítio Arqueológico Menino Jesus.

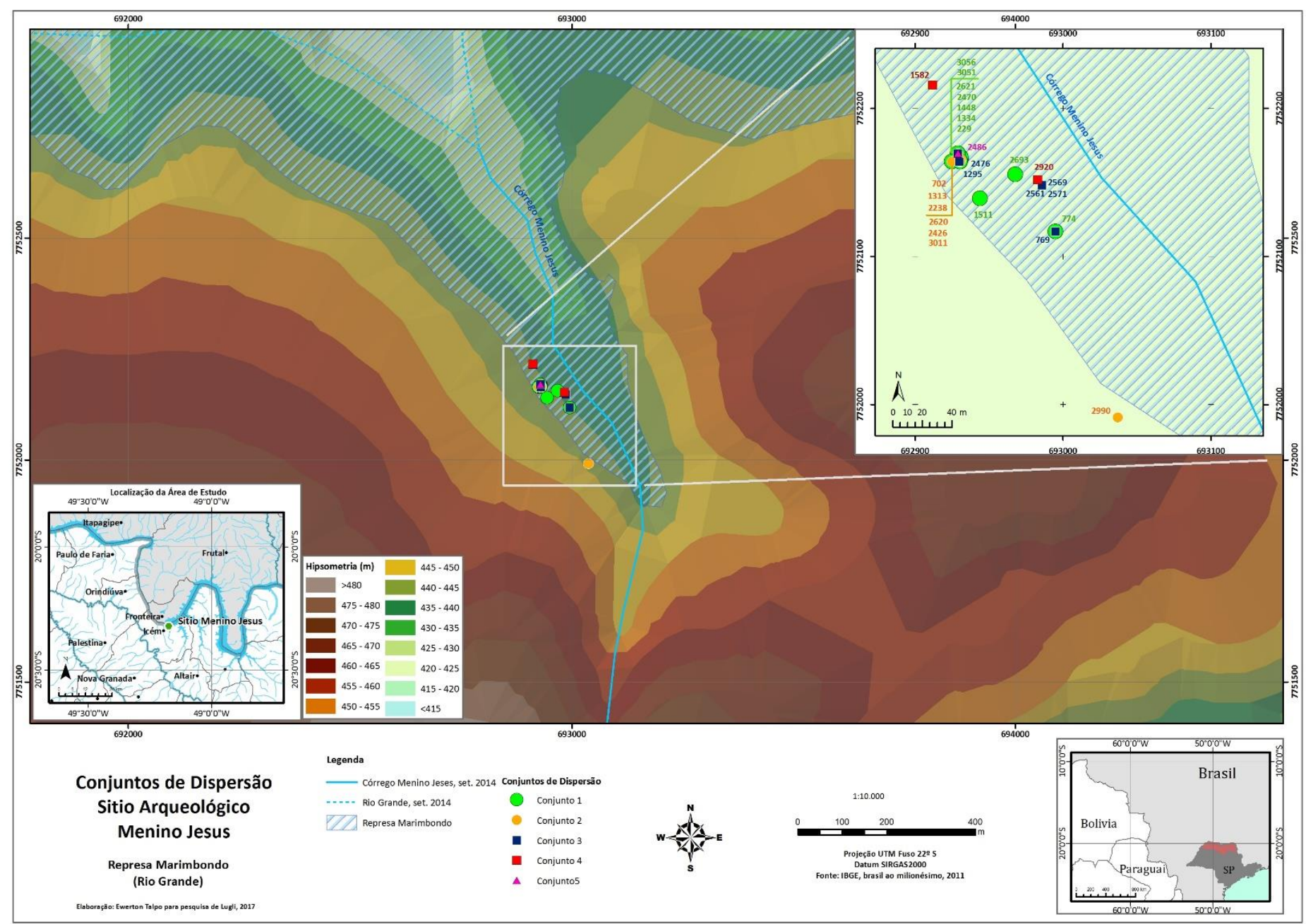

Fonte: IBGE. Confecção - Ewerton Talpo e David Pereira. 
No que se refere aos materiais líticos lascados, houve o resgate de 171 peças tanto em níveis superficiais como em níveis subsuperficiais. No trabalho de curadoria dos materiais coletados, foi possível identificar peças distribuídas entre lascas, núcleos, instrumentos, resíduos e matérias-primas em estado bruto.

O número expressivo de suporte sobre seixo pode nos ajudar a entender o processo de ocupação do Sítio Menino Jesus. Como já comentamos, fatores geoambientais como os afloramentos de argila e as nascentes possibilitaram uma ocupação expressiva na margem esquerda do córrego, com ampla produção de recipientes cerâmicos. No caso do material lítico, a cascalheira detectada na margem do Rio Grande, adjacente ao sítio em apreço, torna-se um geoindicador de suma importância para as interações e atividades locais e extra locais.

Entre os materiais líticos confeccionados no sítio encontram-se as lascas e os raspadores unifaciais e bifaciais. As lascas foram predominantemente confeccionadas em silexito, enquanto os raspadores unifaciais e bifaciais em arenito silicificado. Também foram detectados percutores em arenito silicificado, núcleos, matérias-primas brutas e cascalheira, que em conjunto formam uma cadeia de atividades completa e mostra um circuito de produção e uso local.

Como indicado no Figura 51 os materiais líticos foram detectados nas duas margens do córrego Menino Jesus. O depósito destes materiais tanto na margem direita, quanto na margem esquerda, possui configuração linear e paralela ao corpo de água. A margem direita apresenta maior dispersão e menor concentração de material lítico se comparada a margem esquerda. Enquanto na margem esquerda ocorre concentrações de material lítico coincidentes com as concentrações dos fragmentos cerâmicos, em área que interpretamos como núcleo habitacional, na margem direita ocorre ampla dispersão de material lítico, desde próximo a cabeceira de nascente do córrego até sua desembocadura com o Rio Grande. A detecção de lascas próximas as áreas de cascalheira do Rio Grande são evidências de uso desta fonte para confecção dos instrumentos líticos.

Analisando a plotagem dos fragmentos de cerâmica e dos materiais líticos, suas áreas de dispersão e concentração, notamos que a margem esquerda, com características geoambientais mais aptas a ocupação e produção de cultígenos, parece ter abrigado o núcleo habitacional da aldeia, formada por duas áreas de grande concentração destes materiais, bem como, de maior variabilidade dos mesmos. 
Figura 51 - Mapa de dispersão dos líticos lascados do Sítio Arqueológico Menino Jesus.

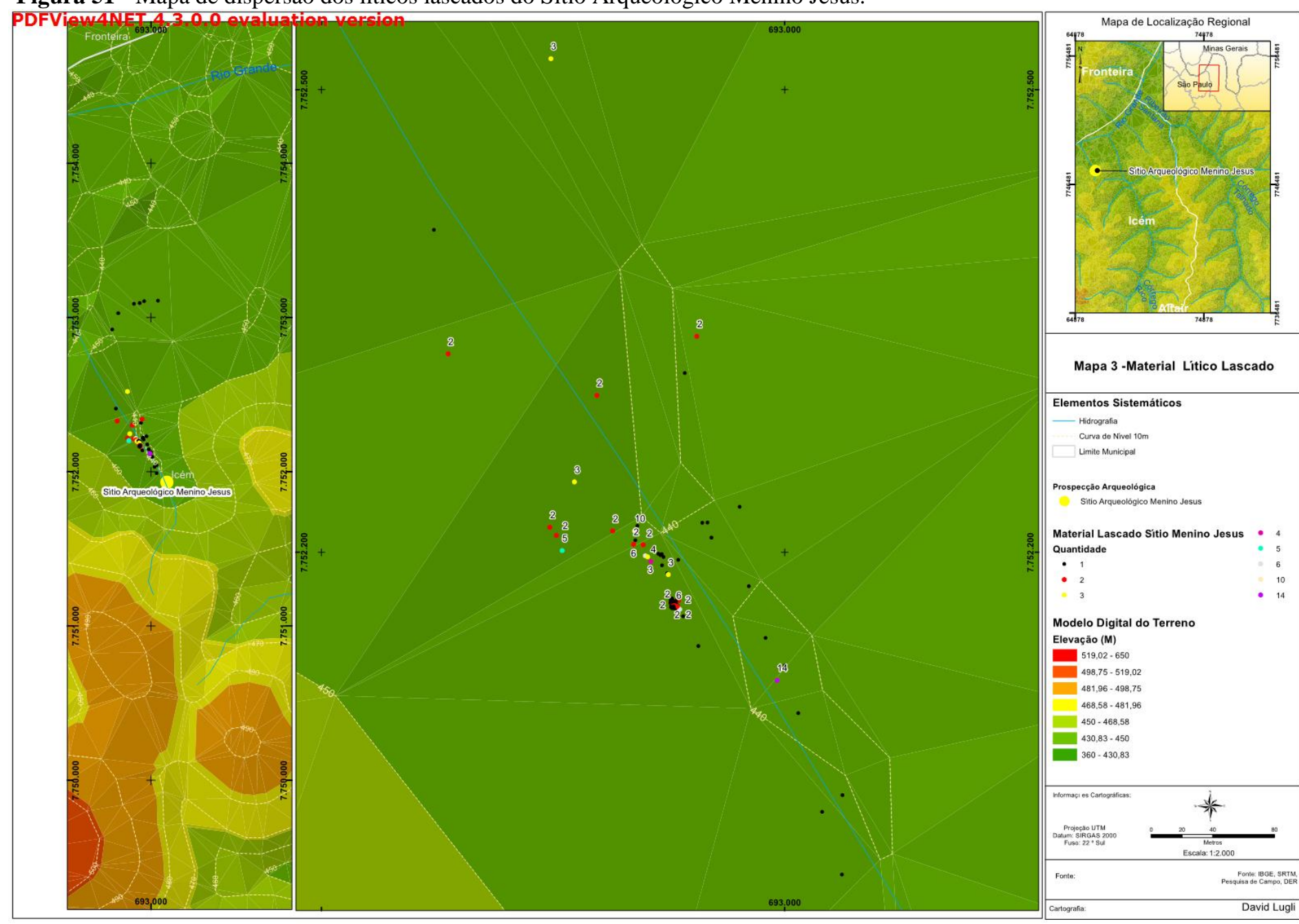

Fonte: IBGE e Google Earth. Confecção - Tadeu Gasparetto e David Pereira. 
A margem direita parece ter sido ocupada de maneira menos intensa ou por menor contingente de pessoas. O que pode nos levar a pensar que tratava-se de áreas de atividades contíguas ao córrego. Não se pode afirmar que tipos de atividades poderiam ocorrer no local, mas como veremos adiante, a maior parte dos líticos polidos foram encontrados nesta margem, indicando uma especialização de atividades neste local (Figura 52).

Exceto uma peça de lítico polido recuperada na Quadra L4 em superfície, as demais foram detectadas na margem direita do córrego Menino Jesus. A deposição dos materiais polidos contrasta com as concentrações de materiais cerâmicos e líticos lascados e pode apresentar áreas específicas de atividades. Calibradores de sulco foram evidenciados próximos uns dos outros, em local plano, próximo ao córrego. Neste local forma-se um banco de areia onde atividades de confecção de lamina de machados e outros instrumentos podem ter ocorrido. Lamina de machado e mão de pilão sugerem atividades agrícolas em fases distintas; o machado na derrubada da mata e capoeira e a mão de pilão para o preparo de alimentos ou extração de seivas ou tintas de plantas e sementes. Os blocos de basalto polido com suaves depressões ou desgastes em seu centro sugerem o aproveitamento das castanhas de Acrocomia aculeata (Macaúba) que é uma palmeira que se apresenta em grande quantidade na área de entorno do sítio. Dificilmente a população indígena que habitou o sítio Menino Jesus não aproveitaria das benesses desta planta. 
Figura 52 - Mapa de dispersão dos líticos polidos do Sítio Arqueológico Menino Jesus.

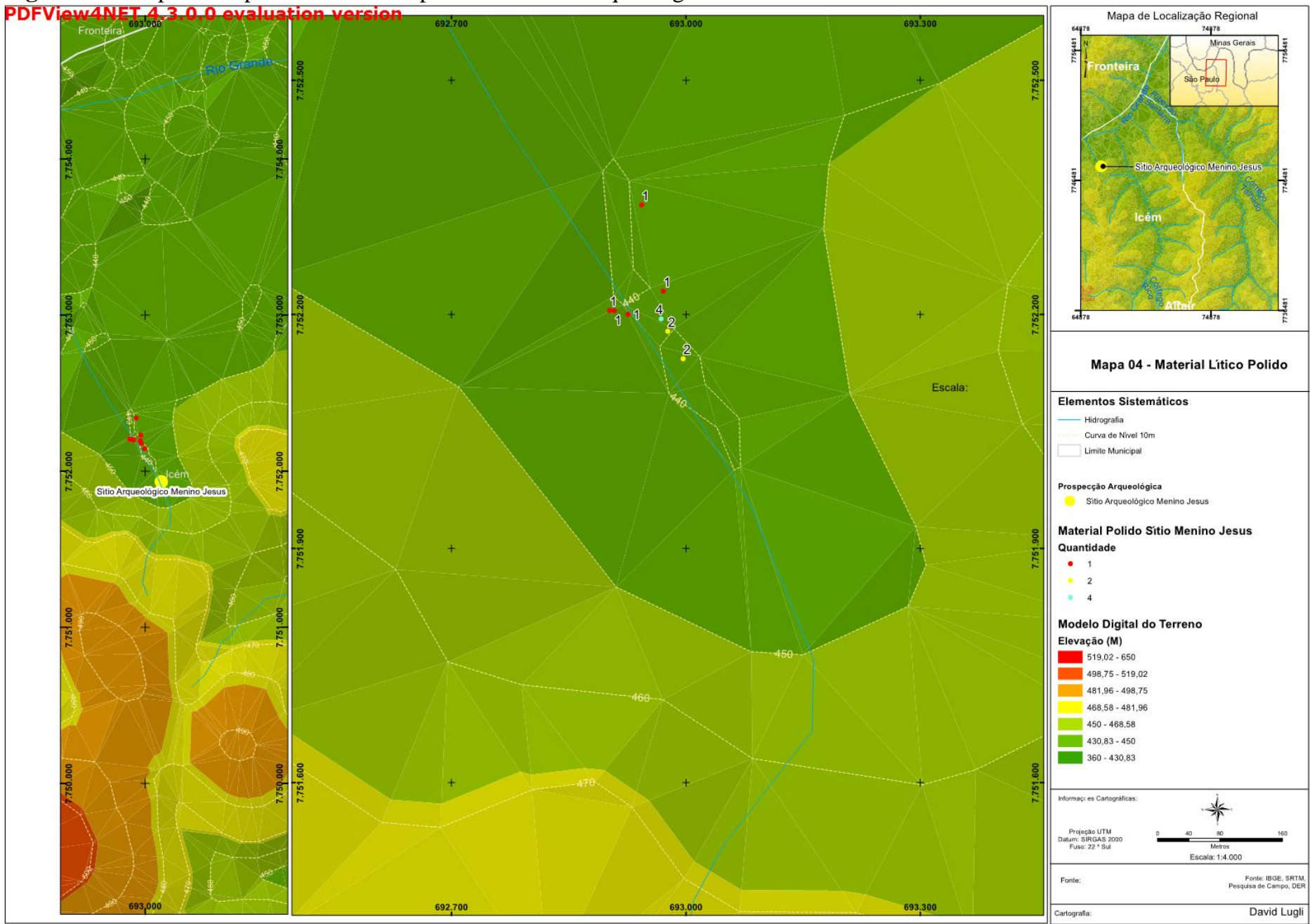

Fonte: IBGE e Google Earth. Confecção - Tadeu Gasparetto e David Pereira. 
O sítio Menino Jesus pode ser considerado como um sítio-habitação. Apresentou configuração linear, sendo identificadas pelo menos duas linhas de deposição arqueológica, em ambas as margens do Córrego Menino Jesus até sua desembocadura com o Rio Grande. Na margem esquerda do córrego ocorre as maiores concentrações de fragmentos cerâmicos e material lítico lascado, enquanto na margem direita documentouse a dispersão de material lítico polido e fragmentos de cerâmica em menor quantidade, embora se estendendo linearmente em uma área contínua maior.

Essa antiga habitação e suas possíveis áreas de atividades foram instaladas em local estratégico onde seus habitantes poderiam ter acesso em abundância a diversos recursos naturais e marcos na paisagem. Entre eles, destaca-se o acesso a água doce em abundância, acesso a um emaranhado de canais e cachoeira do Marimbondo, típicos da formação geológica local deste trecho do rio Grande, acesso a corredeira dos Patos para obtenção de peixes, acesso a ilha frontal onde poder-se-ia encontrar fauna e vegetação circunscrita, acesso a cascalheiras etc. A Figura 53 utiliza-se da base cartográfica elaborada pela Comissão Geológica e Geográfica do estado de São Paulo no ano de 1913 para mostrar possíveis rotas de acesso aos recursos disponíveis nesse trecho do rio Grande e de seus afluentes. 
Figura 53 - Possíveis rotas de acesso aos recursos naturais na área de entorno do sítio Menino Jesus.

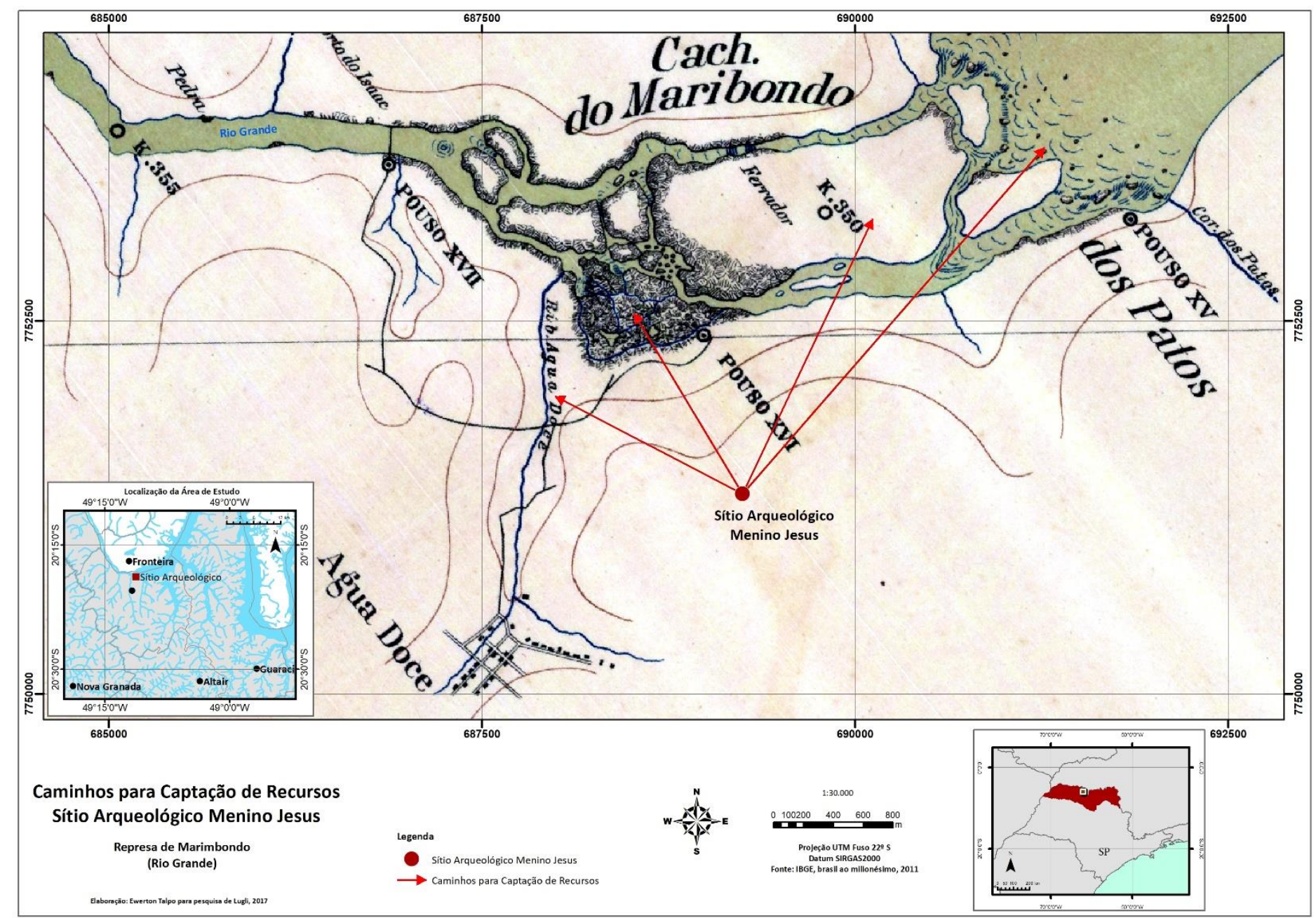

Fonte: Comissão Geológica e Geográfica do estado de São Paulo (1913). Confecção: Ewerton Talpo. 


\subsubsection{O Sítio Arqueológico Santa Filomena}

\subsubsection{Os trabalhos de campo}

Neste item, apresentamos o sítio arqueológico Santa Filomena - com o objetivo de detalhar as pesquisas ocorridas em sua área e lançar as primeiras interpretações acerca desta ocupação colonial. As intervenções ocorreram nos anos de 2013, 2014 e 2015, quando foi realizada a detecção do sítio e as etapas de prospecção e resgate arqueológico (Faccio, 2015)

Segundo Faccio (2015), o sítio Santa Filomena está localizado na Fazenda Santa Filomena, distante 450 metros do córrego do Talhadão (oeste) e a 1000 metros do Rio Turvo (sul). Durante as prospecções realizadas no ano de 2013 e 2014, o sítio foi caracterizado como sendo um antigo cemitério, constituído por muros em estrutura de pedra, formato quadrangular, com cerca de $575 \mathrm{~m}^{2}$, possuindo um cruzeiro em seu centro. O cruzeiro é formado por cruz de aroeira e rochas basálticas em sua base. Dentro do perímetro dos muros, no entorno do cruzeiro, foram contabilizados 22 montes formados por rochas basálticas que conduziram à hipótese de serem túmulos (Figura 54).

Figura 54 - Localização e ilustração do sítio arqueológico Santa Filomena
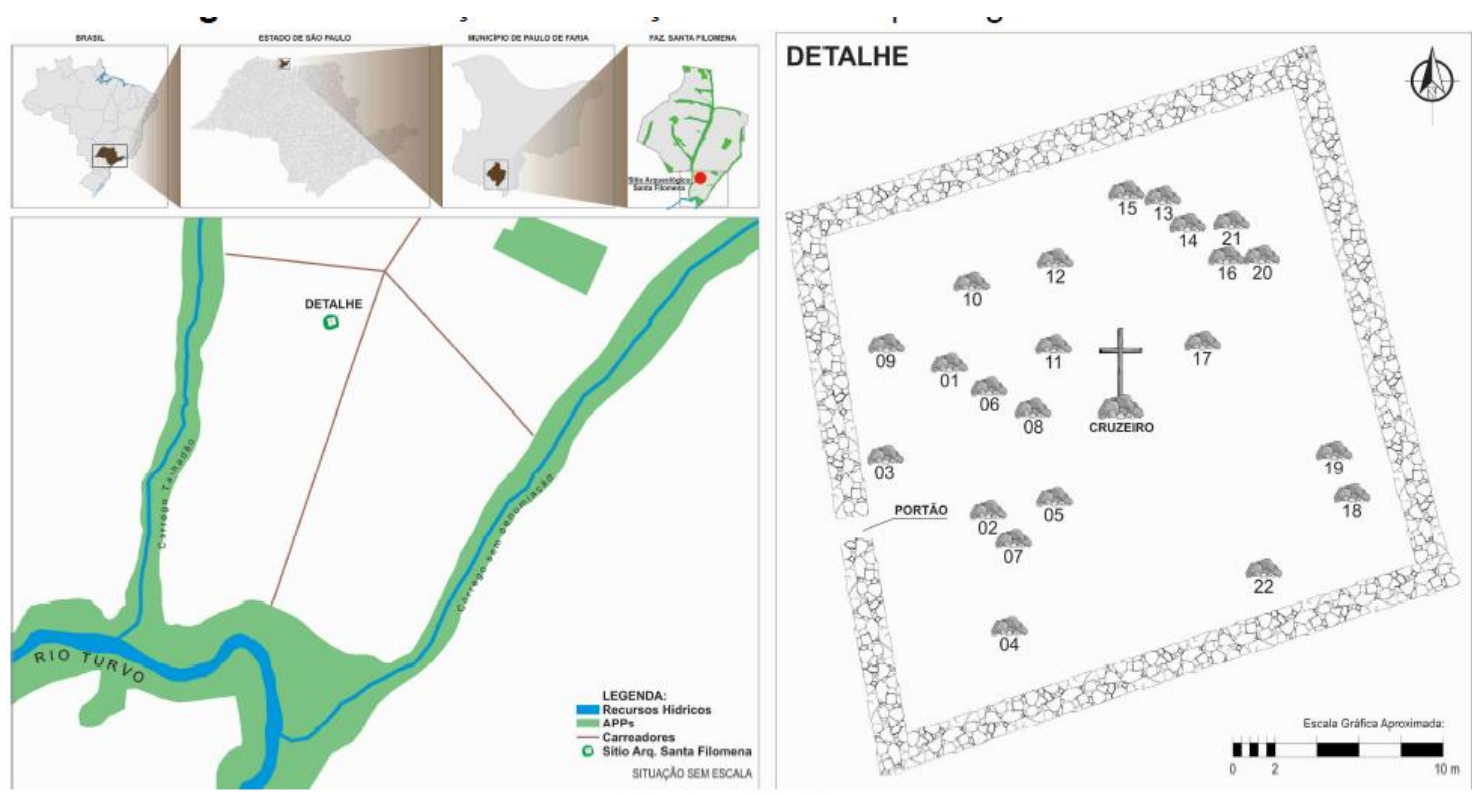

Fonte: Barrocá (20̄15, p.2 āaptado de Faccio 2015). 
O conjunto destes vestígios arqueológicos localiza-se dentro de um polígono de mata secundária, formado por pequenos arbustos e algumas arvores, cercado por lavoura de cana de açúcar. O levantamento arqueológico desta estrutura iniciou-se com a prospecção do seu entorno, objetivando detectar a possível existência de vestígios arqueológicos discretos e/ou em subsolo. Após esta ação, iniciou-se a limpeza da área do sítio, com a retirada da vegetação. Com esta limpeza, notou-se que a parte superior da cruz encontrava-se no solo e partida em três pedaços e que partes do muro estavam desmoronando, devido ao processo erosivo da vertente e pela bioperturbação causada por raízes de árvores, formigueiros e tocas de animais (FACCIO, 2009, 2015).

Na segunda campanha do trabalho de campo na área do sítio arqueológico Santa Filomena (em outubro de 2014), foi finalizada a retirada da vegetação. Todo sedimento retirado junto com a vegetação ou palha foi peneirado, mas nenhum vestígio arqueológico foi encontrado. Após a limpeza, foi possível verificar a forma quadrangular do sítio, com um portão de entrada, bem como a forma do cruzeiro e os 22 túmulos (FACCIO, 2015).

Ainda nesta etapa, foi realizada a decapagem da área do cruzeiro. Foram detectados nesta etapa, fragmentos de vidros e de vaso cerâmico histórico/contemporâneo. Para coletar os materiais evidenciados, a base do cruzeiro foi dividida em quatro setores, sendo eles S1, S2, S3 e S4 (FACCIO, 2015).

Da área do cruzeiro do sítio arqueológico Santa Filomena, foram resgatados 125 fragmentos de vidro e oito fragmentos de cerâmica que compunham um vaso. Durante o resgate do sítio o cruzeiro apresentou seu estipe (base) na posição original, no entanto o patíbulo (travessa) que formava a cruz estava caído, ambos foram constituídos com troncos de aroeira cujas extremidades são esculpidas, além disso a base ainda possui mistura de rochas basálticas e terra para sustentação (BARROCÁ; RAMAZZINA; FACCIO, 2015, p.9).

Os fragmentos de vidro foram analisados por Diego Barrocá, especialista em arqueologia e integrante da equipe do LAG, que conclui tratar-se de partes integrantes de no mínimo treze peças distintas, formadas por garrafas, recipientes planos e recipiente farmacêutico. Uma das garrafas foi identificada como um decantador de vinho (ship decanter) artesanal (Foto 40), produzido pela técnica de sopro livre, possivelmente fabricada durante o século XIX (BARROCA et al, 2015).

Na terceira etapa do resgate, ocorrida em janeiro de 2015, foi realizada uma nova limpeza na área do sítio Santa Filomena e iniciada a decapagem na área do túmulo 2 e em 
parte do muro, adjacente ao mesmo túmulo. O objetivo geral foi o de encontrar evidencias arqueológicas que pudessem situar o sítio no tempo e investigar a técnica construtiva do muro em apreço. Foi delimitada, inicialmente, uma área de 1,20 metros por 2,20 metros para realizar a escavação. As pedras que marcavam o túmulo 2 foram fotografadas, desenhadas e depois retiradas uma a uma, de forma ordenada, numerando-se e fotografando-se cada etapa da ação, para que depois da escavação a estrutura pudesse ser remontada na forma original (FACCIO, 2015).

Foto 40 - Reconstituição do decantador de vinho artesanal

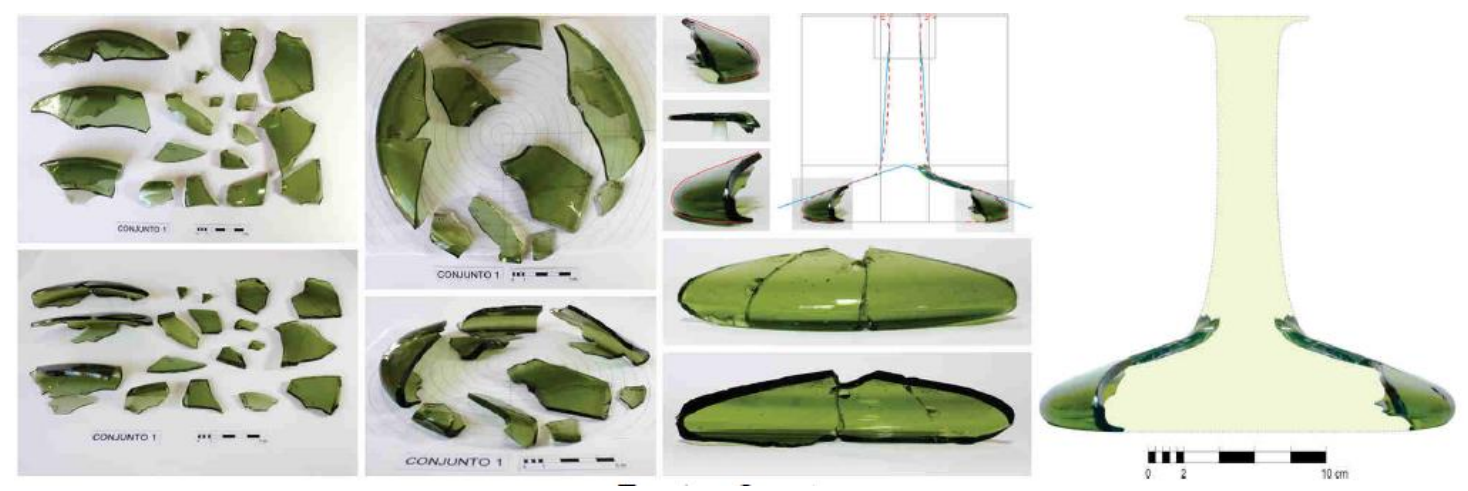

Fonte: Barrocá et. al. (2015, p. 16)

Depois de retiradas as pedras que marcavam o túmulo 2, foi iniciada a decapagem da área delimitada. O sedimento foi retirado de cinco em cinco centímetros e peneirado em seguida. Durante a decapagem, observou-se a presença de raízes da árvore que nasceu entre as pedras do túmulo 2 e, ao sul da quadra, a 30 centímetros de profundidade, três troncos de árvore deitados (FACCIO, 2015).

Diante da evidência arqueológica, decidiu-se abrir mais um metro de cada lado da quadra, formando uma trincheira em formato de $\mathrm{T}$, para verificar do que se tratavam os troncos de madeira encontrados. De um dos lados dessa nova abertura, foram encontradas algumas pedras (FACCIO, 2015).

Segundo Faccio (2015), evidenciada a estrutura de pedra e as madeiras, optouse por retirar os troncos de madeira e as pedras. No entorno das pedras, foi detectada e coletada uma moeda de metal histórica. Após retirados os quatro troncos de madeira e as pedras, seguiu-se com a decapagem e peneiramento, a cada cinco centímetros por quadrícula, até a profundidade de 1,70 metros, sendo que mais nenhum material foi encontrado (Figura 55). 
Figura 55 - Planta de escavação da trincheira do sítio Santa Filomena

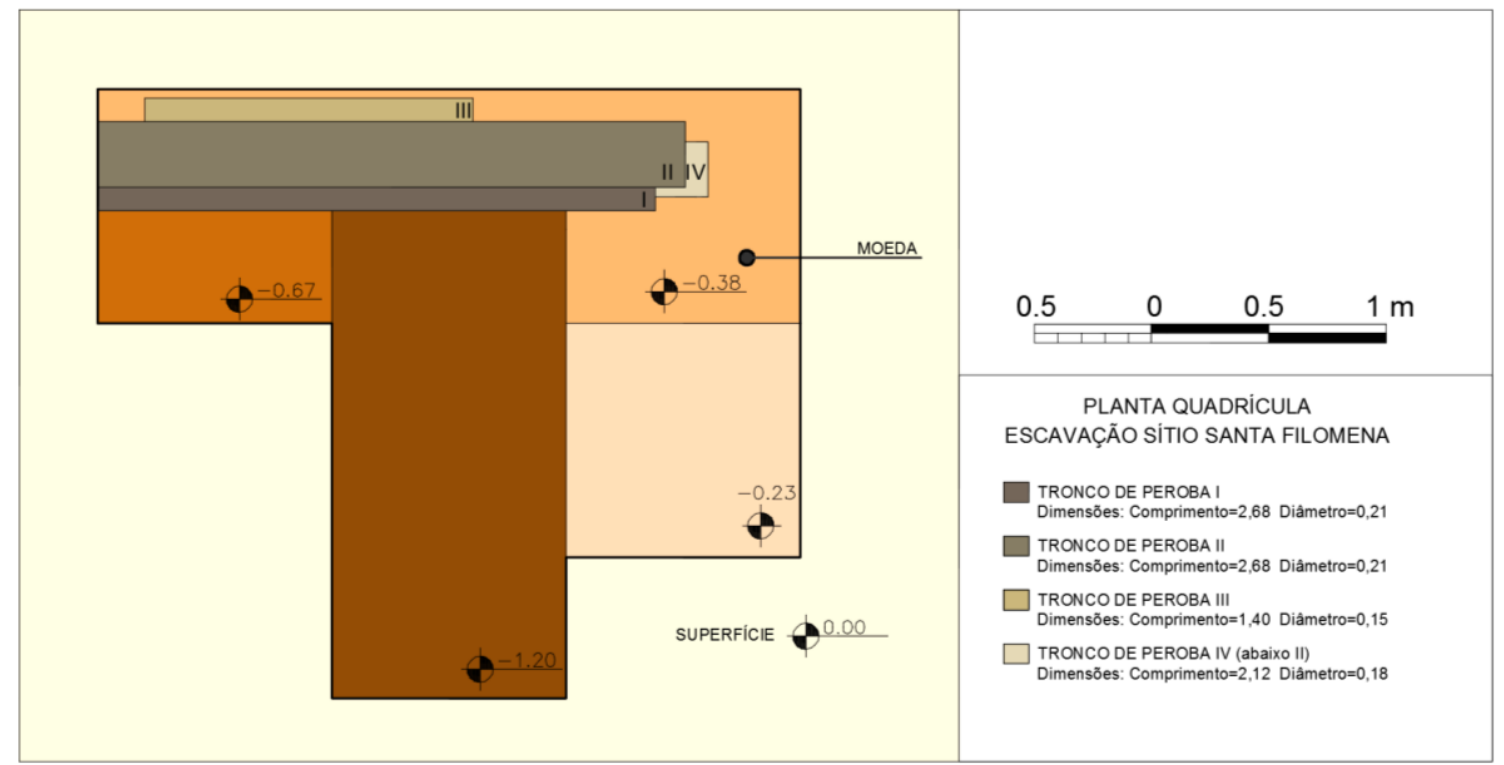

Fonte: Faccio (2015, p.262)

O único material arqueológico confeccionado pela mão humana detectado na trincheira em apreço foi uma moeda histórica (FACCIO, 2015). Segundo Maldonado (2013 apud FACCIO, 2015) a moeda das Fotos 49 e 50 foi confeccionada no período entre os anos de 1823-1829, pela Casa de Fundição de São Paulo, em Cobre. No anverso, tem-se o valor facial entre florões, circundado por anel de tulipas e pela inscrição PETRUS I. D. G. CONST. IMP. ET PERP. BRAS. DEF., e letra monetária SP. No reverso tem-se o Brasão do Império, ladeado acima pela inscrição IN HOC SIGNO VINCES (FACCIO, 2015).

O padrão monetário é o RÉIS, que foi válido até 08/10/1833. Originado no período Colonial por influência do monetário português, não se tratava de uma moeda genuinamente brasileira. Foi aproveitada do padrão português, sem fundamentação legal no Brasil (FACCIO, 2015, p. 277).

Segue as características da moeda de acordo com Faccio (2015, p. 277):

Material: cobre

Diâmetro: $\quad 35,0 \mathrm{~mm}$

Peso: $19,12 \mathrm{~g}$

Espessura: 2,20 mm

Bordo: liso

Eixo: reverso medalha (EV)

Carimbo Geral: 20 
Fotos 41 e 42 - Moeda do Sítio Arqueológico Santa Filomena.
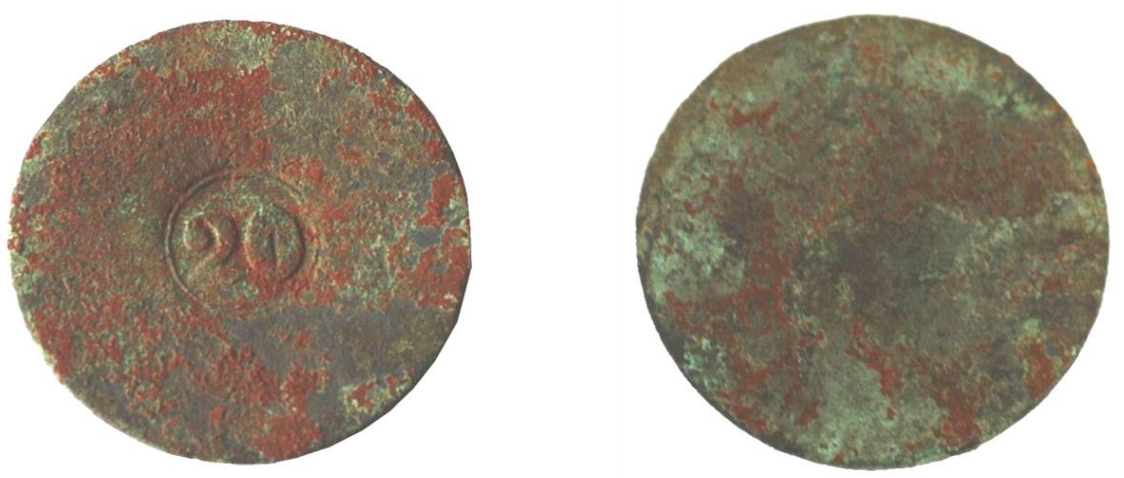

Fonte: Faccio (2015, p. 276).

As Fotos 43 e 44 apresentam um modelo de moeda similar à encontrada na área do Sítio Arqueológico Santa Filomena.

Fotos 43 e 44 - Modelo de moeda do início do século XIX, similar a encontrada no Sítio Santa Filomena.
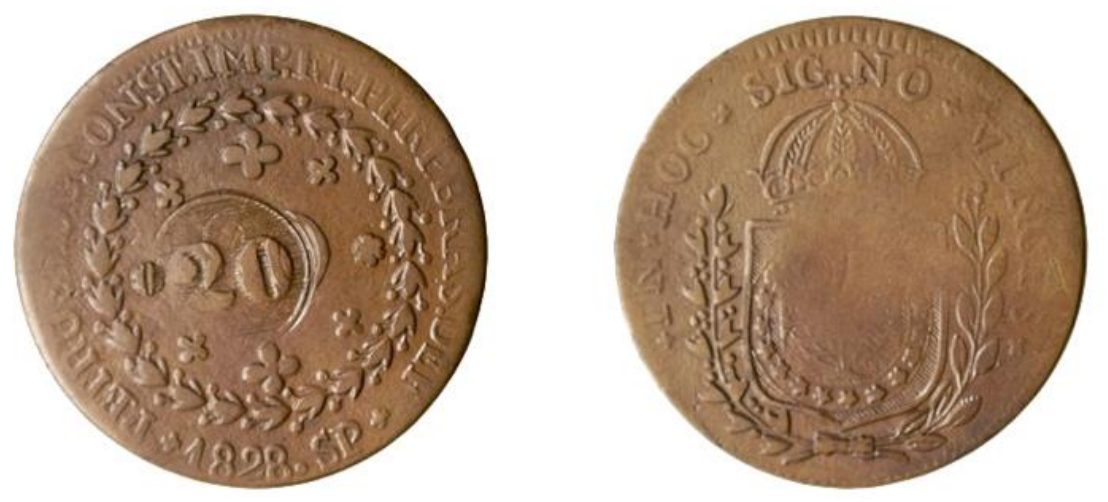

Fonte: Bentes Numismática (2013, apud FACCIO, 2015).

A Tabela 15 mostra as características da emissão desta moeda.

Tabela 15 - Características de emissão de moedas nos anos de 1825 a 1829.

\begin{tabular}{|c|c|c|c|c|c|c|}
\hline ANO & PRODUÇÃO & CRMB & PROVER & AMATO & VIEIRA & BENTES \\
\hline 1825 & $\mathrm{n} / \mathrm{d}$ & $1825-C-080 \times 1$ & & C. 740 & & 484.01 \\
\hline 1828 & $\mathrm{n} / \mathrm{d}$ & $1828-C-080 \times 1$ & C-1339 & C.741 & & 484.02 \\
\hline 1829 & $\mathrm{n} / \mathrm{d}$ & $1829-C-080 \times 1$ & & C. 742 & & 484.03 \\
\hline
\end{tabular}

Fonte: Maldonado (2013, apud Faccio (2015, p. 277). 
Os resultados das etapas de campo realizadas na área do Sítio Santa Filomena proporcionaram o levantamento de hipótese a respeito das técnicas construtivas deste sítio.

De acordo com Faccio (2015), verificando a área do Rio Turvo, encontraram-se rochas ígneas (basalto), iguais às usadas na área do sítio Santa Filomena para a confecção do muro, do cruzeiro e dos túmulos. Este dado corrobora com a hipótese de que o muro foi construído a partir da técnica de pedra seca. Com relação ao método construtivo de pedra seca, temos que "é o tipo mais simples de arrimo, formado pelo arranjo manual de pedras rachão, cuja resistência resulta unicamente do imbricamento dessas peças" (MANUAL DE OCUPAÇÃO, 2015, p. 193 apud FACCIO, 2015, p. 269).

\begin{abstract}
Os blocos devem ter dimensões regulares para sua estabilidade, o que resulta num maior atrito entre as pedras. (...) é de fácil construção e de baixo custo, por não exigir mão-de-obra especializada e, particularmente, se houver jazidas próximas ao local. Dispensa a drenagem interna (barbacãs) pela sua capacidade autodrenante, que evita a ocorrência de pressões da água contra o muro (MANUAL DE OCUPAÇÃO, 2015, p. 193, apud FACCIO, 2015, p. 269).
\end{abstract}

Segundo Colin (2010), a pedra era o material que conferia maior resistência aos muros. "As pedras eram de tamanho variável, até $40 \mathrm{~cm}$ na maior dimensão ou mais, e acabamento irregular, sem qualquer trabalho de aparelhagem. Pedras menores eram colocadas para calçar as maiores" (COLIN, 2010, p. 13, apud FACCIO, 2015, p. 270).

O uso do sistema construtivo de pedra seca era comum na cultura portuguesa. Desta forma, o resultado que se encontrava era sempre muros sólidos de grande largura, estando, em sua maioria, preservados até os dias atuais. Diante do exposto, verifica-se, para a área do muro do sítio em tela, construção mista, ou seja um tipo para área enterrada e outro para a área exposta do muro (FACCIO, 2015).

\title{
3.3.5.2 Os relatos orais
}

Concomitantemente aos trabalhos de campo, Faccio (2015) coletou relevantes informações orais e/ou publicadas de moradores locais e estudiosos. Estas informações foram aqui compiladas conforme o assunto a que se refere. 
Em meio aos trabalhos de campo de janeiro de 2015, foi encontrado por Faccio (2015), um relato publicado no jornal “A Tribuna”, ano de 1988. Neste relato, constam informações valiosíssimas sobre nosso contexto de pesquisa:

O Sr. José Colchoeiro era nosso vizinho e como havia vindo das "bandas" do Talhadão porque alí o Sr. seu pai tinha terras, contava que lá havia vestígios de uma vila feita pelos padres jesuítas, inclusive um cemitério todo cercado por pedras, um cruzeiro e mais coisas [...] [...] Arrumamos uma caravana composta de nossos familiares, isto lá pelos anos de 1943 e num caminhão de propriedade de meu sogro, João de Matos Pinto, fomos fazer um pic-nic no Talhadão e um reconhecimento do local tão apregoado pelo José Colchoeiro, que também foi conosco.

[...] Atravessado o brejo, logo acima deparamos com os vestígios tão anunciados e a nossa curiosidade foi crescendo cada vez mais. Logo na chegada a Vila de São Vicente do Talhadão, como era chamada pelos antigos moradores daquela região, deparamos com um rego rasgado no chão que vinha de muito longe e dava a impressão que seria agua colhida rio acima para as utilidades da vil, ou talvez para tocar alguma roda d'agua ou monjolo para o benefício dos cereais ali produzidos ou trazidos. Em seguida, vinham os vestígios de uma enorme casa porque ainda existiam os baldrames de madeira que iria sustentar a parte superior da casa. Ali o José dizia que era a Casa dos Padres, pois dava a impressão de ter um cômodo para a igreja, outro para os aposentos e um enorme salão que deveria ser escola ou oficina de trabalho, como também depósito de mantimentos. O interessante é que os encaixes da madeira eram de uma perfeição total e os pregos usados eram de madeira com uma segurança inédita. Logo ao centro da vila havia mais vestígios de casas e uma enorme cruz em madeira trabalhada, portando uma escadinha e um lança iguais às que foram usadas na morte de Jesus. Continuamos em frente até chegarmos no cemitério e qual não foi a nossa surpresa. É igualzinho como o José nos contava, todo cercado por um muro de pedras sobrepostas, de uma fundura razoável e na altura de mais ou menos dois metros, em forma piramidal com os cantos muito bem formados, tendo um portãozinho muito bem talhado em madeira e dentro do cemitério havia diversas cruzinhas demarcando onde possivelmente foram enterradas pessoas ali existentes. Numa dessas cruzinhas, tivemos a oportunidade de ver uma data feita por pedacinhos de ferro em forma de tachinhas dizendo o ano em que foi ali enterrado alguém "1777". Tivemos a vontade de trazer o portãozinho, a cruz com a data e também muitos cacos de cerâmicas por ali espalhados, mas como sempre tem os supersticiosos, demoveram a nossa vontade, e por isso não pegamos nada que pudesse comprovar a existência daquela Vila. No Talhadão, do lado de Rolândia tem um desvio no Rio Turvo que é chamado de "Graminha" e que nos dava a impressão que aquele desvio foi feito pelos moradores da Vila de São Vicente do Talhadão, para poder tocar alguma serraria ou coisa semelhante, porque havia muitos moirões de aroeira fincado mais abaixo das corredeiras. $\mathrm{O}$ seu 
José confirmava que de fato ali havia uma serraria porque os antigos moradores assim diziam. Há ainda muitos moradores daquelas bandas que conhecem tudo isto que aqui estou descrevendo, e ainda tenho vontade de lá voltar para ver se ainda existem os vestígios acima descritos. Os fazendeiros daquela região não respeitaram a existência da Vila e formaram pasto em toda a área e os animais e fogo talvez tenham reduzido a nada o que vimos e até tiramos fotos que remetemos ao jornal "Folha da Manhã" de São Paulo, onde saiu uma reportagem completa. Vale a pena formarmos uma comitiva e tornar a ver se ainda existe alguma coisa do que vimos. (JORNAL A TRIBUNA, 1988, apud FACCIO, 2015, p. 274 - 275).

Diante do exposto, destacam-se algumas informações coletadas por Faccio (2015) que nos ajudam a contextualizar o sítio arqueológico Santa Filomena:

1- o relato foi conferido por um morador das imediações no início da década de 1940

2- o local era chamado de vila de São Vicente do Talhadão, pelos antigos moradores da região;

3- havia o conhecimento público de que o local era constituído por antigas estruturas de um cemitério cercado por pedras, um cruzeiro etc, construídos por padres jesuítas;

4- a testemunha ocular registrou vestígios de uma enorme casa, conhecida como Casa dos Padres, um centro para vila, com vestígios de casas e cruz de madeira, bem como, o cemitério cercado por pedras sobrepostas, com diversas "cruzinhas" demarcando possíveis túmulos;

5- a testemunha ocular descreve que em uma das "cruzinhas" havia data feita por "pedacinhos de ferro em forma de tachinhas", informando o possível ano de enterramento, que era 1777 ;

6- o relato publicado descreve, provavelmente, o sítio Santa Filomena e seu entorno. No entanto, restou apenas o cemitério daquilo que um dia foi chamado de Vila de São Vicente do Talhadão.

Passemos para outros relatos, estes registrados por Faccio (2015) durante a decapagem da base do cruzeiro, situado no centro do antigo cemitério, onde se detectaram fragmentos de vidros oriundos de antigas garrafas. Segundo Milton Ávila, trabalhador de campo da Usina Moema, 58 anos, morador de Palestina, SP, "o costume de molhar o crucifixo, do cemitério, era porque se acreditava que isso traria chuva". Outro depoimento colhido por historiador local segue no mesmo sentido: 
Quando era estudante, de primeiro grau, em escola rural - no bairro Boiadeiro - em época de seca, a professora levava os alunos até o rio, com uma garrafa, para coletarem água. Levavam a água até o crucifixo, localizado em frente à igreja do bairro, e molhavam o crucifixo como forma de penitência para chover. Era tradição na região enterrar o indivíduo com os pés voltados para a entrada do cemitério. (Antônio Carlos Carvalho, historiador, Palestina, SP. Depoimento realizado em 28 de janeiro de 2015, apud FACCIO, 2015, p. 243).

Segundo Faccio (2015), o Senhor Joaquim Vicente morador local relatou uma experiência de sua infância na área do cemitério:

Fazíamos novena no cruzeiro para não perder a roça. Vinha debaixo de chuva. Rezavam o terço e molhavam a cruz e deixavam as garrafas vazias, isso tem 48 anos. Meu pai fala que era trazido com carretão de boi. Os fazendeiros que traziam o pessoal de Areia Branca vinham pedir água aqui. (Joaquim Vicente, trabalhador de campo da Usina Moema. Depoimento realizado no dia 28 de janeiro de 2015).

Do exposto, Faccio (2015) verifica que era costume na região molhar o pé do cruzeiro para clamar por chuva. Sendo este costume antigo, é provável que os vidros recuperados no trabalho de decapagem na área do cruzeiro formem um amalgama de vários períodos históricos (FACCIO, 2015).

O último relato apresentado por Faccio (2015) aconteceu de forma espontânea, quando a equipe de campo estava executando a decapagem do túmulo 2. Ao encontrar três troncos de árvores dispostos na horizontal, próximo ao muro de pedra, o senhor Itamar deu o seguinte depoimento:

Segundo histórias contadas pelo avô "senhor Arthur", as pessoas mais ricas eram embrulhadas em um lençol e enterrados em uma cova há "sete palmos". Por cima, colocavam troncos de madeira de aroeira e depois jogavam terra por cima. Por fim, colocavam um crucifixo em cima da cova. (Itamar Evangelista Ribeiro, trabalhador de campo da Usina Moema, 56 anos, morador de Palestina, SP. Depoimento realizado no dia 28 de janeiro de 2015, apud Faccio, 2015, p. 255 - 256).

Os relatos aqui mencionados sinalizaram um ponto de partida para a pesquisa histórica acerca do que foi o sítio Santa Filomena, na época de sua construção e funcionamento. 


\subsubsection{Histórico da vila de São Vicente do Talhadão}

O histórico de formação e ocupação da vila de São Vicente do Talhadão possui três personagens preponderantes: o fazendeiro João Batista Siqueira e os padres da Congregação da Missão de São Vicente de Paulo, Pe. Jerônimo Gonçalves de Macedo e Pe. José Vicente Gonçalves de Macedo.

Segundo a Enciclopédia dos Municípios Brasileiros, Volume XXIV (1958), a história inicia-se com João Batista Siqueira, destemido vaqueiro e sertanista paulista, que fugindo à ação da justiça de Jacareí/SP, procura asilo entre os Kayapó, no extremo oeste do Triângulo Mineiro, no início do século XIX.

Nesta região, Siqueira monta seu império de terras com a construção da fazenda de Campo Belo, dedicando-se à criação de gado e expandindo suas posses em quase todo o território, onde hoje se situa o município de Campina Verde/MG. No ano de 1827, Siqueira já bastante rico, doente e sem herdeiros, resolve destinar todos os seus haveres à Congregação da Missão de São Vicente de Paulo, representada à época pela pessoa do Padre Leandro ${ }^{76}$.

No ano de 1830, a referida congregação obtém a licença do Governo Imperial Brasileiro para a aquisição de bens imóveis no país. Siqueira e sua mulher, Dona Barbara, doavam as fazendas de Campo Belo, Perobas e Fortaleza, com área aproximada de 28 mil alqueires.

A partir desta doação de terras, os padres da congregação estabeleceram no Triângulo Mineiro, na fazenda Campo Belo, o segundo foco da Missão de São Vicente de Paulo, favorecendo o povoamento da região. Ressalta-se que a doação de terras realizada por Siqueira possuía duas cláusulas que deveriam ser cumpridas: 1- construção de uma capela para atender as necessidades locais e 2- construção de um colégio de Primeiras Letras. As determinações exigidas pelo falecido seriam cumpridas pelo Pe. Jerônimo Gonçalves de Macedo, que no ano de 1834 assumiu a administração das terras doadas (INACIO FILHO; FARIA; SILVA, 2007).

A primeira cláusula foi consumada em 1835, com a construção da capela e em 1838, o Pe. Macedo fundou o Colégio Campo Belo, primeiro centro de ensino desta região. Neste período ocorre o povoamento do Arraial de Campo Belo, que repercute nas transformações arquitetônicas eclesiásticas, com a construção de uma nova capela em

\footnotetext{
${ }^{76} \mathrm{O}$ documento não faz referência ao sobrenome do referido padre.
} 
1850 , sobre a de 1835 e outra, ainda mais recente, no ano de 1885 , sobre a de 1850 , demonstrando o sucesso que a congregação obteve em seu objetivo de colonizar e evangelizar este sertão de Minas Gerais (IBIDEM, 2007).

Na mesma época da fundação da primeira capela e do colégio no Arraial de Campo Belo, por volta do ano de 1835, também é criada uma capela e um aldeamento dedicado aos Panará (Kayapó), às margens do Rio Grande, denominado São Francisco Sales. O que se sabe é que o aldeamento também teria sido criado pelo Pe. Jerônimo Gonçalves de Macedo e teria sido o marco inicial para o povoado e, consequentemente, $\begin{array}{lllll}\text { para a fundação do município de São Francisco Sales/MG } & \end{array}$ (Disponívelem:http://www.memorialdosmunicipios.com.br/listaprod/memorial/historico -categoria,192, H.html Acesso em: 24 Novembro de 2017). Alexandre de Sousa Barbosa (1918) nos informa que, no primeiro quartel do século XIX, este aldeamento contava com mais de 1000 indígenas.

O documento denominado "Memorial de Riolândia" nos fornece o fio condutor de toda esta história surgida no Triângulo Mineiro. Conta-nos que, com o falecimento do Padre Macedo em janeiro de 1860, o colégio de Campo Belo passou a ser administrado pelo Pe. José Vicente Gonçalves de Macedo, sobrinho do padre falecido. O mesmo deu continuidade ao trabalho de seu tio em relação aos povos nativos, mas, também, passa a explorar e povoar os sertões do Triângulo Mineiro ainda "selvagens". Foi neste interim que o padre, descendo o Rio Verde, até sua confluência com o Rio Grande, estabeleceu contato com os Kayapó aldeados em São Francisco Sales. Após um período não mencionado no texto, o Padre transpõe o Rio Grande e penetra no sertão paulista, através do Rio Turvo. Neste rio, a missão catequista vicentina estabelece uma colônia no local, próximo à cachoeira do Talhadão, que nas décadas posteriores passou a ser chamada de Porto do Marques. Após a pacificação dos Kayapó e colonização destas terras, o padre abre caminho para a vinda de diversas famílias, que seguiram o mesmo percurso missionário e vieram a ocupar estas terras do Turvo.

No ano de 1913 pesquisadores da Comissão Geográfica e Geológica de São Paulo realizaram exploração do Rio Turvo, a partir de sua confluência com o Rio Grande. $\mathrm{O}$ texto nos informa que os pesquisadores fizeram uma paragem de algumas horas no recente povoado de São Vicente ou do Marques, que foi descrito como composto de uma capela e quatro casas. No entanto, os pesquisadores não demoraram no povoado, seguindo para Cachoeira do Lageado, onde iriam prestar ajuda a duas canoas da comissão que haviam naufragado. No dia seguinte, continuaram sua viajem pelo Rio Turvo, 
informando-nos que ao cair da tarde chegaram ao Salto do Talhado, descrevendo-o como dique de diábase que atravessa o leito do rio e corre estreito entre suas margens escarpadas (COMISSÃO GEOGRÁFICA E GEOLÓGICA DO ESTADO DE SÃO PAULO, 1913).

O maior legado desta Comissão para nossos estudos sobre o aldeamento de São Vicente do Talhadão foi a planta do Rio Turvo, em escala 1:50.000 (Figura 56), onde foram cartografados o aldeamento e o Salto do Talhado. No documento, observa-se uma estrada que liga este núcleo até a cidade de São José do Rio Preto.

Não há, nos documentos consultados, uma data específica para a criação desta colônia ou aldeamento chamado São Vicente do Talhadão. O que se sabe é que as pesquisas arqueológicas identificaram 1- recipiente do tipo decantador de vinho em vidro artesanal, possivelmente fabricado no século XIX e 2- moeda confeccionada em cobre, que circulou entre os anos de 1823 a 1829. Relato publicado em jornal local aponta que 3- morador teria visitado o cemitério na década de 1940 e avistado cruzinha de ferro sobre enterramento, com a data de 1777. Finalmente, os registros históricos colhidos nos informam que 4- após o ano de 1860, o Pe. Macedo empreende uma missão evangelista nos sertões de São Paulo, fundando colônia próxima à Cachoeira do Talhadão e no ano de 1913, pesquisadores da Comissão Geográfica e Geológica fazem rápida paragem no "recente povoado". 
Figura 56 - Aldeamento de São Vicente do Talhadão e área de entorno

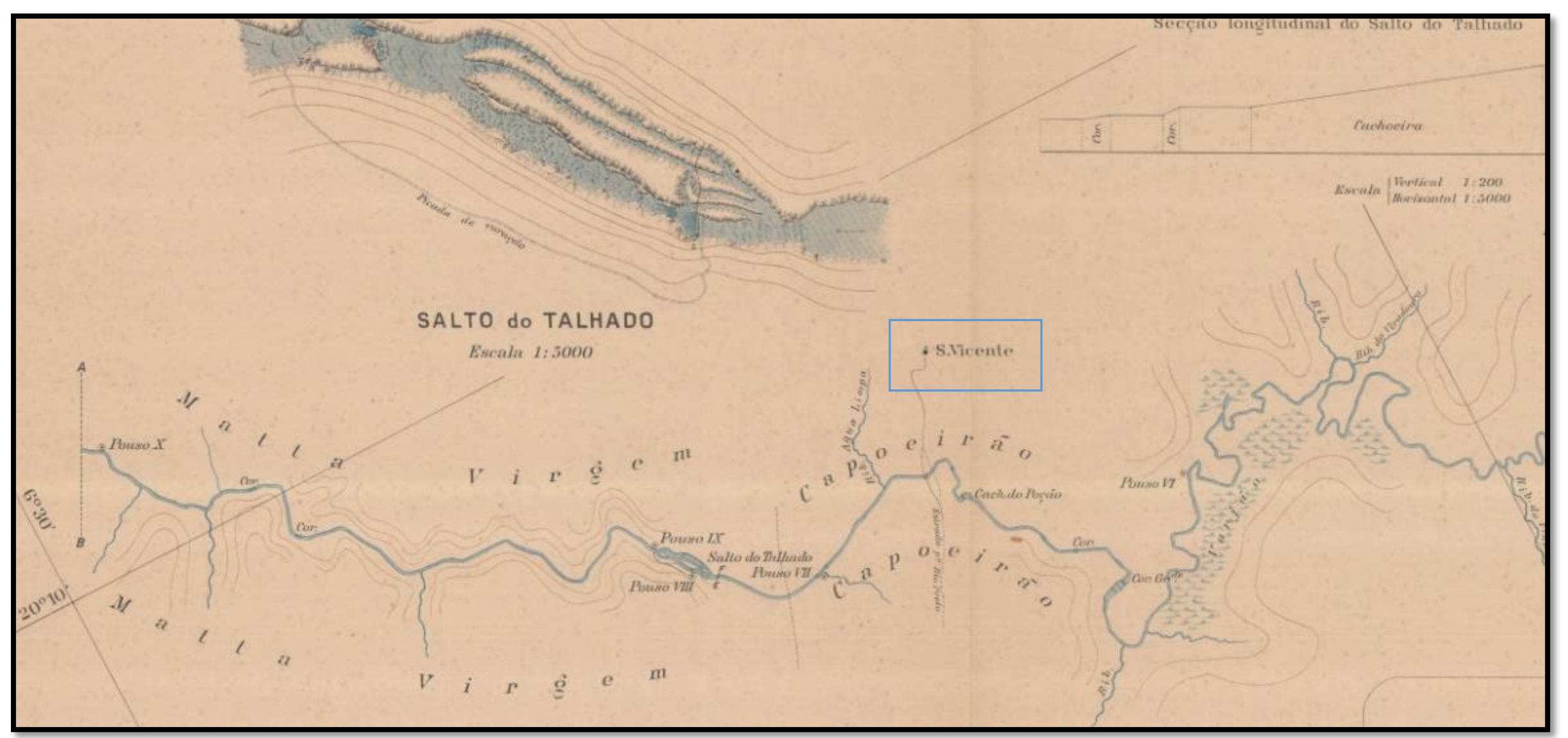

Fonte: Comissão Geográfica e Geológica do Estado de São Paulo (1913, p. Folha XVII). 
CAPÍTULO 4

SISTEMAS REGIONAIS DE POVOAMENTO

IDENTIFICADOS NO CAR 
O objetivo deste capítulo foi conectar os conceitos e as linhas de pesquisas descritas no Capítulo 1, com os dados regionais acerca da arqueologia e da etno-história, descritos no capítulo 2, e com os dados levantados sobre os sítios arqueológicos, investigados no capítulo 3 da presente tese.

Trata-se de estabelecer um modelo de ocupação regional para o norte do estado de São Paulo, com base no conceito de sistema regional de povoamento, desenvolvido por José Luiz de Morais (1999-2000).

A primeira etapa de entendimento desse conceito é realizada pela análise espacial, que, por meio do uso de mapas de distribuição de sítios e de artefatos, atua no reconhecimento sistemático dos padrões espaciais dos sítios arqueológicos, auxiliando na compreensão da inserção dos antigos assentamentos/áreas de atividades na paisagem (MORAIS, 1999-2000).

Com base nessa investigação, pode-se inferir sobre o padrão de assentamento, compreendido pelo conhecimento das estratégias socioespaciais das antigas comunidades que influenciaram na distribuição do povoamento pelo espaço geográfico e, finalmente, compreende-se o sistema regional de povoamento, que é a coordenação entre os sítios ou conjuntos de sítios cartografados em certa região, que demonstrem "relações concomitantes por contemporaneidade, similaridade ou complementaridade" (MORAIS, 1999-2000, p.207).

Para o entendimento e aplicação do conceito de sistema regional de povoamento, devemos enfatizar o fator Geo (MORAIS, 1999) que visa, principalmente, extrair informações pertinentes à análise dos padrões de assentamento, sua relação com o meio físico-biótico, recomposição dos principais traços da paisagem à época das ocupações, enfoques etnoarqueológicos/etno-históricos e procedimentos e técnicas de datação para inserção cronológica dessas ocupações humanas no passado.

O fator Geo implica a formulação de procedimentos relativos a conexões viáveis entre a prática arqueológica e as ciências da terra, "culminando em levantamento dos cenários das ocupações humanas do passado, visando à interpretação no nível da demarcação territorial das antigas comunidades" (MORAIS, 1999, p.5). Assim, a abordagem de caráter ambiental elevada pelo fator Geo tem o propósito de auxiliar a tentativa de identificação das estratégias socioespaciais das comunidades do passado (MORAIS, 1999, p.8).

Buscou-se, no estudo do sistema regional de povoamento, apresentar certos padrões da organização socioespacial de grupos culturais distintos na escala de tempo, 
espaço e comportamental. A variabilidade da organização socioespacial dos assentamentos/áreas de atividades em nível regional e os padrões de apropriação do espaço físico forneceram elementos empíricos imprescindíveis para a interpretação da paisagem, objeto de nossa pesquisa.

Esta proposta de trabalho fundamenta-se no estudo de critérios de seleção e implantação dos sítios arqueológicos na paisagem, começando com o entendimento da hidrografia, topografia e geomorfologia das áreas ocupadas, os parâmetros locacionais, características do material arqueológico e estruturas, morfologia e função dos assentamentos, bem como, relações sincrônicas e diacrônicas entre o mesmo sistema de povoamento e entre sistemas distintos.

Ao final da síntese interpretativa, forneceram-se subsídios para uma melhor compreensão da expansão e ascensão das populações indígenas que habitaram o norte do estado de São Paulo, bem como do seu declínio causado pela territorialização colonial luso-brasileira.

\subsection{Sistema de Povoamento Regional Aratu-Sapucaí}

O arqueólogo Renan Pezzi Rasteiro (2015; 2016) realizou importante levantamento e sistematização de dados arqueológicos na Bacia do Rio Grande, margem paulista. Este levantamento apresentou um total de 152 sítios cerâmicos ou litocerâmicos, dentre os quais, 49 foram considerados pertencentes à tradição aratu, nove à tradição tupiguarani, um à tradição uru, dois característicos das tradições aratu/tupiguarani e seis das tradições aratu/uru.

Os dados acima levantados revelam que a maior parte dos sítios arqueológicos localizados na bacia do Rio Grande, margem paulista, estão relacionados a grupos Jê vindos do centro-oeste do país. Estes grupos agricultores ceramistas são conhecidos como pertencentes à tradição aratu-sapucaí e à tradição uru.

Grupos detentores da cerâmica aratu e grupos detentores da cerâmica uru teriam entrado em contato de modo sistemático, numa área que abrangeu o vale do Araguaia e o alto Tocantins, a partir dos séculos X/XI da Era Cristã. Segundo Robrahn-Gonzalez (1996) a continuidade deste contato teria levado a uma fusão entre estes grupos ceramistas emergindo uma nova unidade cultural que iria se estender por todo centro-sul de Goiás e posteriormente para áreas mais meridionais do país. 
Munido deste conhecimento, Morais (1999-2000) ponderou que as tradições aratu, sapucaí e uru poderiam formar um extenso sistema regional de povoamento de agricultores pré-coloniais do Brasil Central, com influências significativas pelo território do sudeste. Reconhece-se, no entanto, que este sistema regional de povoamento guarda peculiaridades específicas para a região norte do estado de São Paulo, em relação à configuração de seus sítios, variabilidade cerâmica e interações culturais com povos ceramistas relacionados aos Tupiguarani.

A análise sincrônica dos sistemas regionais de povoamento no norte do estado de São Paulo possibilitou reconhecer um padrão de ocupação socioespacial. Os sítios identificados que apresentaram cerâmica característica dos Aratu-Sapucaí localizaram-se no extremo norte e a leste do CAR, próximos ao Rio Grande, embora raramente instalados em suas margens. Estes grupos preferiam ocupar as margens dos tributários do Rio Grande, como o Turvo, o Pardo e o Sapucaí Mirim, em área de média-vertente. Raros foram os assentamentos que ocuparam a baixa-vertente, sendo representados apenas pelos sítios Cervo (395 \pm 40 A.P.) e Água Azul II (465 \pm 65 A.P.), ambos localizados na bacia do Rio Sapucaí-Mirim, apresentando pequena dimensão e baixa quantidade de materiais.

Dentre estes sítios, os que apresentaram maior quantidade de materiais foram os Turvo Vb, Turvo I e Turvo IV, localizados na bacia do Rio Turvo-Grande, e o Bela Vista do Jacaré, localizado na Bacia do Pardo-Grande. Estes sítios podem remeter às grandes aldeias associadas aos grupos culturais do Brasil Central, embora não se tenha identificado a sua configuração circular característica. Nota-se que estes sítios maiores estão próximos a sítios menores, não ultrapassando distâncias de quatro quilômetros, como é o caso de Bela Vista do Jacaré, em relação ao Santo Antônio do Lajeado e o Balsamina e os Turvos Vb, I e IV, em relação aos Turvos Va e III.

Num plano central obliquo do CAR, seguindo do alto curso do Rio Turvo, próximo ao baixo Pardo, até a confluência do Rio Turvo com o Rio Grande, têm-se a maior quantidade de sítios que apresentaram fusão e/ou interação entre tradições distintas. É o caso dos sítios Agua Limpa ${ }^{77}$, Ribeirão das Pitangueiras (Aratu-Sapucaí e Uru), Olímpia VII (Aratu-Sapucaí e Uru), Menino Jesus (Aratu-Sapucaí, Tupiguarani e Uru) e Água Vermelha (Tupiguarani e Uru).

A divisão territorial do CAR se caracteriza por apresentar a oeste, o predomínio de sítios filiados ao sistema regional de povoamento guarani, ao norte e a leste, o

\footnotetext{
${ }^{77}$ Sem filiação, mas que apresenta características da cerâmica aratu-sapucaí e tupiguarani.
} 
predomínio de sítios filiados ao sistema de povoamento regional aratu-sapucaí, e no centro, numa faixa obliqua que liga o sul ao norte da referida área de estudo, acompanhando a bacia do Rio Turvo e adjacências, o predomínio de sítios filiados ao sistema de povoamento regional aratu-sapucaí, com cerâmicas apresentando características mistas.

Outro padrão espacial digno de nota é a presença de sítios arqueológicos próximos a áreas de saltos/cachoeiras no rio Grande. Esta característica socioespacial pode estar associada tanto a captação de recursos naturais (peixes, afloramento de rochas, cascalheiras etc) quanto para sua travessia. Adjacente a cachoeira da Água Vermelha temos o conjunto de sítios Água Vermelha, próximo a cachoeira dos Índios temos o aglomerado de sítios Turvo e adjacente a cachoeira de Marimbondo/Salto dos Patos temos o sítio Menino Jesus. Apresentamos nas Figuras 57 e 58 as plantas das cachoeiras de Água Vermelha e Marimbondo confeccionadas pelos pesquisadores da Comissão Geográfica e Geológica do estado de São Paulo (1913) em escala 1:6.000.

A análise diacrônica oferece-nos outras chaves interpretativas para complementarmos o entendimento da ocupação socioespacial no CAR.

A ocupação territorial mais antiga está relacionada à área central obliqua que liga o sul ao norte (ou norte ao sul) e que acompanha a bacia do rio Turvo e adjacências. Neste cenário, o sítio mais antigo está representado pelo Água Limpa, inserido nas cabeceiras do Turvo, ao sul do CAR.

Se pensarmos na hipótese de trabalho levantada por Robrahn-Gonzalez (1996), a ocupação mais antiga para nossa área de estudo deveria estar situada em um dos grandes saltos/cachoeiras do Rio Grande, ao norte do CAR, pois estas localidades seriam as possíveis rotas dos grupos culturais vindos do Centro-Oeste do país. No entanto, raros foram os levantamentos arqueológicos executados nestas áreas de "passagem" do Rio Grande e poucas são as datações para os sítios já levantados. Outro problema é que estas áreas já foram inundadas por usinas hidroelétricas, como a UHE Água Vermelha ou a UHE Marimbondo, e provavelmente muitos sítios hoje estão submersos ou encontram-se em áreas de depleção. 
Figura 57 - Salto de Água Vermelha, bacia do rio Grande.

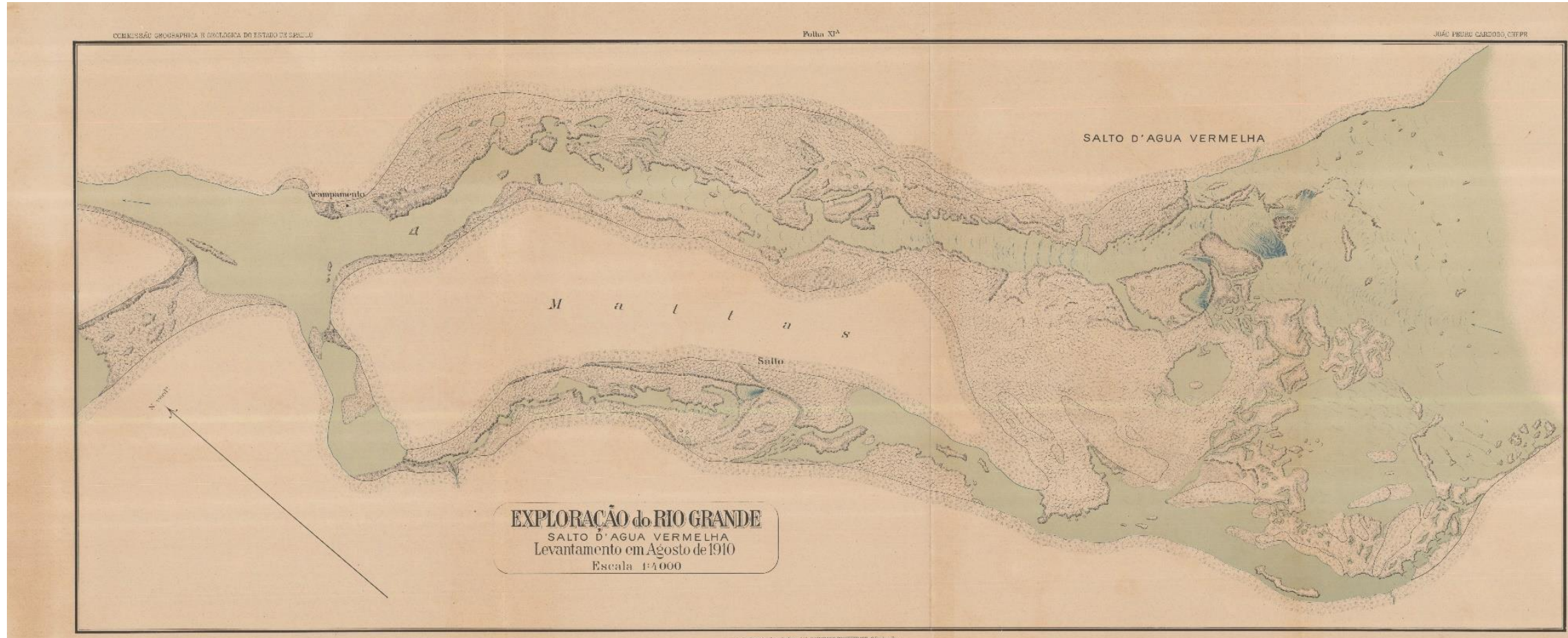

Fonte: Comissão Geográfica e Geológica do Estado de São Paulo (1913, p. Folha XI). 
Figura 58 - Cachoeira do Marimbondo/Salto dos Patos, bacia do rio Grande.

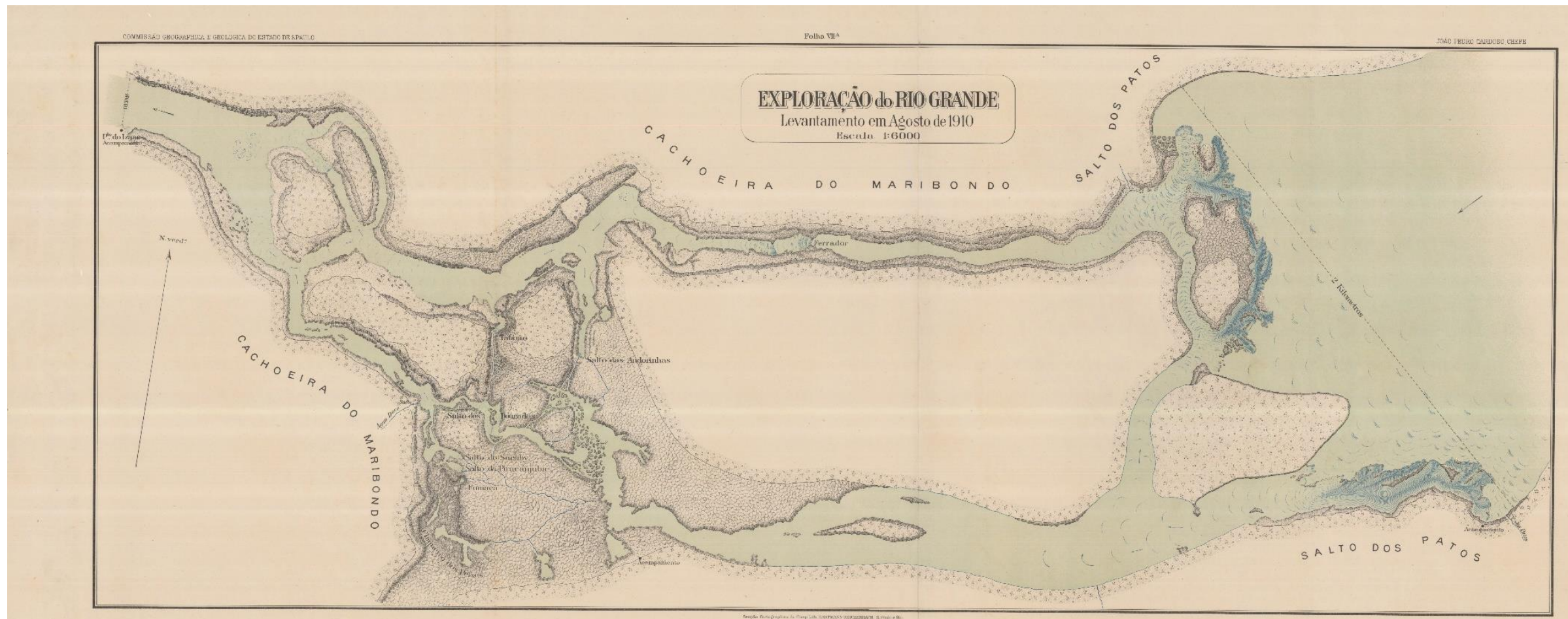

Fonte: Comissão Geográfica e Geológica do Estado de São Paulo (1913, p. Folha XII). 
Mesmo trabalhando com um cenário bastante incompleto, nota-se um padrão de ocupação diacrônica no CAR. Com exceção do sítio Água Limpa, que no futuro será melhor compreendido em termos regionais, os sítios mais antigos localizam-se ao norte, sobretudo, próximos à Cachoeira da Água Vermelha, Cachoeira dos Índios e Cachoeira do Marimbondo/Salto dos Patos. A ocupação de grupos agricultores ceramistas por esta região iniciou-se no começo do século XI e se estendeu até o final do século XIII / início do XIV. Um segundo cenário de ocupação seria, provavelmente, a entrada de grupos aratu-sapucaí de Minas Gerais para São Paulo, por meio da confluência do Rio Pardo e Sapucaí-Mirim, por volta do início do século XVI da Era Cristã.

A partir do início do século XVIII, surgem documentos históricos que relatam a presença de grupos dos Kayapó Meridional em vasto território, cobrindo todo centro-leste goiano, leste sul matogrossense, Triângulo Mineiro e norte de São Paulo. Estes grupos apresentaram características socioespaciais que foram documentadas durante sucessivos períodos de colonização ibero-brasileira.

Entre as principais características destacamos: 1- organizavam-se em aldeias de tamanhos distintos, tendo cada aldeia seu chefe; 2- possuíam lideranças regionais que geriam várias aldeias; 3- a distribuição das aldeias acontecia próximo a grandes rios e seus afluentes, geralmente instaladas próximas a saltos e/ou cachoeiras; 4- os assentamentos eram formados por uma rede socioespacial, configurada por área de habitação, roças e acampamentos; 5- as aldeias possuíam formato circular, apresentando número de oito a dez habitações, com a casa dos homens no centro; 6- alta mobilidade espacial para sua subsistência, como abertura de roças distantes da aldeia e incursões a longínquas áreas florestadas, em busca de caça e coleta.

Sítios arqueológicos inseridos no CAR, que apresentaram datações recentes ${ }^{78} \mathrm{e}$ características ceramistas dos Jê, como o Rosário, Olímpia VII, Turvos e até mesmo a última fase de ocupação do Água Limpa, podem estar associados aos grupos conhecidos como Kayapó Meridional. A maior parte dos sítios Turvo, bem como o Água Limpa (última fase de ocupação), poderiam caracterizar-se como grandes aldeias kayapós no estado de São Paulo. Os sítios Olímpia VII e Rosário, apresentando uma quantidade de material mais modesta, poderiam formar aldeias menores ou até mesmo áreas de roça ou acampamentos sazonalmente ocupados por estes grupos indígenas.

\footnotetext{
${ }^{78}$ Faixa cronológica que se inicia em meados do século XVII e abrange todo o século XVIII.
} 


\subsection{Sistema de Povoamento Regional Guarani}

$\mathrm{O}$ atual estágio de pesquisa para o sistema de povoamento regional guarani do oeste paulista nos mostra que as ocupações de maior porte, com mais de quatro manchas pretas, estão localizadas próximo às margens dos rios maiores, como os rios Paraná e Paranapanema (FACCIO, 2017). Sítios de pequeno porte, com pouca densidade de registro arqueológico, foram registrados por Faccio (1998), e podem estar associados a áreas de acampamento sazonal ou de atividades de roça. Essas duas áreas junto à aldeia faziam parte de um sistema de exploração ecológica, tipicamente guarani, assegurando em seu território (tekoá) o seu domínio de influência político-espacial e o melhor aproveitamento dos recursos naturais.

No contexto do Alto Paraná e Bacia do Paranapanema, teriam os grupos guarani se adensado nessa região, por volta do ano 1.000 ao ano 700 antes do presente (presente: Século XI ao XIV da Era Cristã), sem que se desconsiderem ocupações mais antigas e recentes a essa faixa cronológica. Expandiram-se pelos principais canais fluviais, ocupando toda a geomorfologia local, desde os terraços e várzeas, até as colinas e relevo de Cuestas Basálticas do Paranapanema (PEREIRA, 2011).

Segundo as datações obtidas para os grupos ceramistas guaranis no estado de São Paulo, supõe-se que teriam ocupado, primeiramente, as margens dos canais principais, com melhores condições de captação de alimentos, navegabilidade e aproveitamento de matéria-prima, deslocando-se, expansivamente, para os tributários mais afastados, à medida que seu sistema de ocupação territorial necessitasse (IBIDEM, 2011).

Quanto à cronologia para os sítios localizados no Alto Paraná Paulista, temos apenas a datação absoluta do Sítio Lagoa São Paulo, situado em 1.050 anos antes do presente. No lado sul matogrossense, a faixa cronológica média dos sítios guaranis esteve situada em 500 anos antes do presente, fazendo-se exceção ao Sítio Lagoa do Custódio, com datação de 1.200 anos antes do presente (IBIDEM, 2011).

Na bacia do rio São José dos Dourados, a ocupação guarani apresentou-se bastante recente, possivelmente, relacionada ao período histórico de colonização do oeste paulista e áreas adjacentes.

A maior parte dos sítios localizam-se nos tributários de ambas as margens do Rio São José dos Dourados. No caso do sítio Santa Cruz, distando cerca de até $6 \mathrm{~km}$ do 
mesmo. Os tributários da margem esquerda do Rio São José dos Dourados têm suas nascentes localizadas na cabeceira de drenagem, que separa esta bacia da bacia do Rio Tiete (ao sul) e os tributários da margem direita têm as suas nascentes localizadas na cabeceira de drenagem, que separa esta bacia da bacia do Rio Turvo (nordeste) e Rio Grande (norte).

Os sítios estão instalados num eixo norte-sul, com diâmetro aproximado de 20 km. Dentro deste espaço, os sítios apresentam distância média entre si de aproximadamente três quilômetros, formando um aglomerado de ocupação guarani.

Mostram-se como sítios pequenos, com baixa quantidade de cerâmica, geralmente caracterizada por apresentar antiplástico mineral associado com caco-moído e uma frequência de $6 \%$ a $8 \%$ de tratamento de superfície cromático (engobo e/ou pintura) e plástico. Os sítios que apresentaram maior quantidade de fragmentos cerâmicos foram o Abelha, com 901 fragmentos, e o Meridiano, com 830 fragmentos. Uma característica marcante foi que a maior parte dos sítios apresentaram cariapé como tempero para o fabrico da sua cerâmica ${ }^{79}$, mostrando uma característica local associada a grupos jês, vindos do Centro-Oeste brasileiro.

Apresentaram uma faixa cronológica de ocupação desta bacia que se estende de $455 \pm 80$ A.P. até $175 \pm 30$ A.P. O período cronológico mais recuado no tempo está correlacionado aos sítios guaranis do Alto Paraná sul matogrossense, situados em 500 anos antes do presente. Já o período mais recente pode estar associado às movimentações guaranis de oeste para leste, em território nacional, que se iniciou por volta de 1830, pelas quais grupos migravam em busca de uma terra mítica (yvy maraey) e provavelmente usaram o curso do Tietê para tal empreitada (MORAIS, 1999-2000). No Mapa EtnoHistórico de Curt Nimuendaju (1987), é possível ver em sua cartografia a entrada de grupos guaranis no ano de 1887, do atual estado de Mato Grosso do Sul para São Paulo, exatamente onde está localizada a bacia do São José dos Dourados. Faz-se a ressalva de que essa penetração de grupos guaranis, no final do século XIX, nesta bacia, foi possível devido ao aniquilamento de grande parte da população kayapó meridional, provocando vazios territoriais.

\footnotetext{
${ }^{79}$ Variando de $16 \%$ a $2 \%$, a ocorrência deste tempero em alguns sítios arqueológicos.
} 
Figura 59 - Famílias Linguísticas do Estado de São Paulo, segundo Nimuendaju 1987.

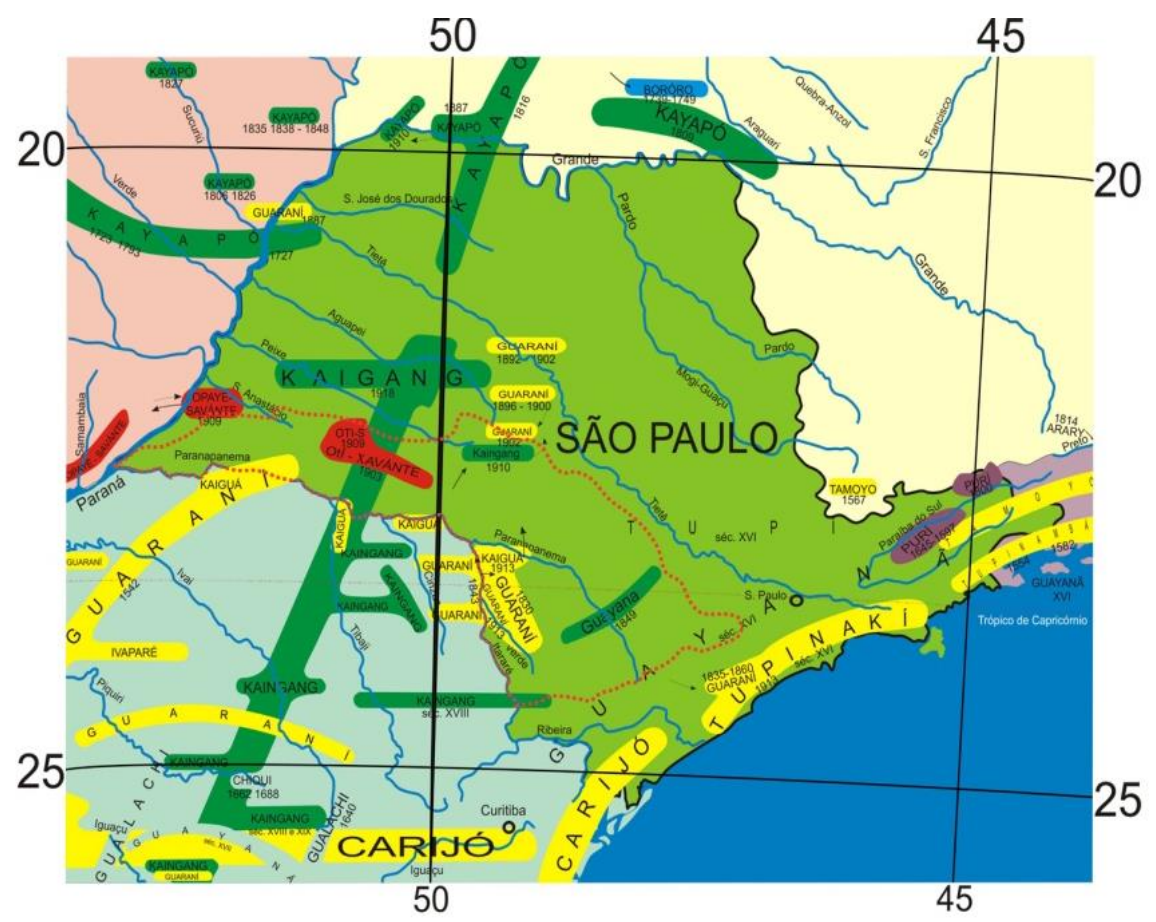

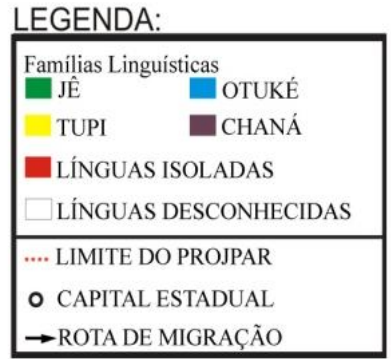

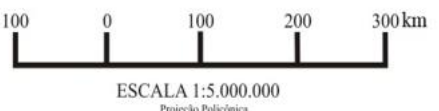

Produção Gráfica: Gabriel Loschiavo Cerdeira

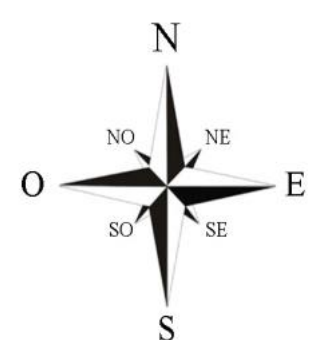

FONTE:

Mapa Etno-Histórico de Curt Nimuendaju/ Fundação Instituto Brasileiro de Geografia e Estatística em colaboração com a Fundação Nacional Pró-Memória. Rio de Janeiro: IBGE; 1987. PRIMEIRA EDIÇÃO

Fonte: Mapa Etno-Histórico de Curt Nimuendaju (1987). Confecção: Faccio (2011).

É certo que o cenário delimitado para o Sistema Regional de Povoamento Guarani, que abrange parte da bacia do Rio São José dos Dourados não configure um volume de dados satisfatórios para uma análise regional. É necessário que a realização de novas pesquisas e a somatória de novos dados possam acontecer, para que se expanda o conhecimento da ocupação nesta área. O que podemos tecer até o momento é que se trata de uma ocupação caracterizada por apresentar sítios pequenos, pouca quantidade de materiais, instalados, sobretudo, na cabeceira de pequenos tributários de ambas as margens do São José dos Dourados, apresentando na pasta de suas cerâmicas, o tempero cariapé, característico de grupos jês vindos do Centro-Oeste brasileiro. 


\subsection{Os aldeamentos regionais}

Para esta pesquisa, foram detectados três aldeamentos, dois instalados à margem do Rio Grande, lado mineiro, e um à margem do Rio Turvo, lado paulista. Embora, apenas o aldeamento de São Vicente do Talhadão faça parte da área delimitada para nossos estudos, os aldeamentos mineiros de São Francisco Sales e de Água Vermelha apresentaram proximidade física e contextual.

Sabe-se que a formação destes aldeamentos está diretamente ligada à exploração do ouro nos sertões de Goiás, propulsor do capitalismo mundial durante os séculos XVII e XVIII. Com o processo de invasão territorial, ocorreram os primeiros contatos entre os mineradores e os grupos indígenas ocupantes da região norte e nordeste do estado de São Paulo e regiões adjacentes, sobretudo aqueles pertencentes à família jê, seus antigos habitantes. O reflexo da exploração mineira no estado de Goiás e Minas Gerais foi a intensificação do fluxo comercial entre essas áreas auríferas e o estado de São Paulo. Feita por via terrestre, a estrada que interligava os dois trechos foi denominada "caminho de Goiás", atravessando todo o sul de Goiás, onde hoje se encontra o Triângulo Mineiro, até chegar ao estado de São Paulo, cortando uma área de ocupação tradicional kayapó meridional (GIRALDIN, 1997, 2000).

A exploração do ouro e o conflito entre colonizadores e indígenas fizeram com que Machado de Oliveira (1861, p. 502) se queixasse de que no início do século XVIII havia sido de "triste e lamentável nomeada pelo que passou no território abraçado pela serra Santa Martha, e sulcado pelos rios Paranahyba e Grande, e com o qual confinavam as capitanias de S. Paulo, Minas e Goyaz".

A violência e a repercussão da guerra encarniçada entre os conquistadores e os Kayapó fizeram com que a Coroa se manifestasse e emitisse ordem para que houvesse brandura durante este processo de colonização. Uma de suas estratégias foi a tentativa de aldeamento das tribos indígenas, onde a "maior parte da renda do dízimo sobre gêneros era destinada à civilização e edificação de aldeias. Os jesuítas deviam ser importados, sem consideração de despesas, e todo o apoio lhes foi prometido, para serem empregados como missionários" (POHL, 1951, p.309). Nessa época, muitos aldeamentos foram instalados, sobretudo, no estado de Goiás, Mato Grosso e Minas Gerais (GIRALDIN, 2000; VASCONCELOS, 2013).

No entanto, com o aprofundamento dos estudos dos aldeamentos de São Francisco

Sales, Água Vermelha e São Vicente do Talhadão descobrimos que os mesmos não foram 
fundados por padres membros da Companhia de Jesus e sim por padres da Congregação da Missão, fundada na França por São Vicente de Paula.

Com a instalação da Congregação da Missão em Campo Belo, Minas Gerais (hoje Campina Verde), deu-se início ao processo de aldeamento e povoamento dos sertões do oeste deste estado. Em 1835, funda-se à margem do Rio Grande uma capela e um aldeamento denominado São Francisco Sales. No ano de 1871, as famílias indígenas que formavam este aldeamento migravam para um local próximo, chamado Cachoeira, que, segundo Giraldin (1997), provavelmente fazia referência à Cachoeira de Água Vermelha.

Em 1911, Barbosa (1918) menciona que essa população do aldeamento Água Vermelha estava reduzida a 50 indivíduos, mas que, segundo informações orais recebidas por seus moradores, no início da década de 1880, o local era formado por uma grande aldeia kayapó-panará, com aproximadamente 600 habitantes.

Importante salientar que, tanto São Francisco Sales, quanto Água Vermelha eram aldeamentos instalados próximos a dois grandes saltos/cachoeiras, a dos Índios e de Água Vermelha, respectivamente. É possível que a escolha destas áreas tenha sido feita pelos padres devido à sua facilidade de travessia para o estado de São Paulo. No entanto, estas duas áreas foram historicamente procuradas por populações indígenas associadas a grupos jês, séculos antes das incursões colonizadoras.

Como mencionado no capítulo 3, a história de formação do aldeamento São Vicente do Talhadão conecta-se ao Triângulo Mineiro, pelo fato de sua fundação ser uma extensão do processo iniciado na década de 1830, em Campo Belo, pela Congregação da Missão. Sabe-se, por meio da coleta de dados de campo, laboratório, informação oral e documental histórica, que o Padre Gonçalves de Macedo, após o ano de 1860, transpondo o Rio Grande, direção Minas Gerais para São Paulo, chega à margem do Rio Turvo, onde estabelece uma missão catequista vicentina. Esta missão foi descrita em 1913, por pesquisadores da Comissão Geográfica e Geológica, como composta por uma capela e quatro casas. As pesquisas arqueológicas não identificaram estas antigas estruturas, mas sim, um antigo cemitério, que provavelmente pertencia a este aldeamento, mas não foi mencionado à época da visita destes pesquisadores. Interessante pontuar que, assim como os aldeamentos mineiros citados, o São Vicente do Talhadão também se encontrava próximo a um salto denominado Talhadão.

É corriqueiro notar nas descrições de aldeamentos dos séculos XVI e XVII, no estado de São Paulo e século XVIII e XIX, em Goiás, a redução de povos indígenas em territórios administrados por ordens religiosas, tendo como critérios a necessidade de 
defesa frente aos grupos indígenas ainda não aldeados e obtenção do usufruto das áreas das antigas aldeias indígenas pré-existentes. O objetivo era obter o máximo aproveitamento destes conhecimentos pré-estabelecidos, como proximidade com os rios piscosos, aproveitamento das trilhas terrestres e vias hidrográficas navegáveis e campos de boa visibilidade e ótima topografia para a proteção de ataques inimigos (CAMPOS, 2006; JULIANI, 2013).

Sobre esta característica de ocupação colonial religiosa, Campos (2006) descreve que a criação da Casa Jesuítica no planalto paulistano (posteriormente Pateo do Collegio) priorizou campo apropriado, entre eles, segundo consta na carta do Padre Manuel da Nóbrega, o assentamento em acrópole, muitos metros acima do nível da água, gozando os moradores da pureza do ar de lugares altos, vantagens defensivas e ampla proteção proporcionada pelas íngremes escarpas do Rio Tamanduateí, voltadas para o Ribeirão Anhangabaú. No entanto, a preexistência nas imediações deste aldeamento de um intricado sistema de trilhas indígenas, que cortavam em todos os sentidos a vertente do interflúvio, constitui-se a característica principal locacional deste assentamento.

Havia nos aldeamentos paulistas do século XVI, um padrão de assentamento caracterizado por ocupação no topo de uma colina, às margens de rio navegável, tendo como premissa obter ampla vista dos arredores e proximidade aos cursos de água (SCATAMACCHIA, 2016). Padrão este semelhante ao aldeamento de Mossâmedes em Goiás (descrito por Saint-Hilaire no início do século XIX), que estava implantado em cume de colina, rodeado por morros, e regado por córrego na base da vertente.

Já o sítio Santa Filomena, onde anteriormente se encontrava o aldeamento de São Vicente do Talhadão, encontra-se distante 450 metros do Córrego do Talhadão (oeste) e a 1000 metros do Rio Turvo (sul) em área de média-alta vertente. A posição estratégica atendia aos requisitos já mencionados em outros aldeamentos, como boa visibilidade de entorno, próximo a grande rio, presença de salto/cachoeira nas proximidades e possivelmente fazia parte de uma rede de caminhos que interligava o Triângulo Mineiro ao sertão noroeste de São Paulo.

Apresentamos abaixo a Figura 60 que compila as informações levantadas nesse capítulo em linguagem cartográfica. 
Figura 60 - Sistemas Regionais de Povoamento no CAR e suas possíveis rotas de expansão pelo território

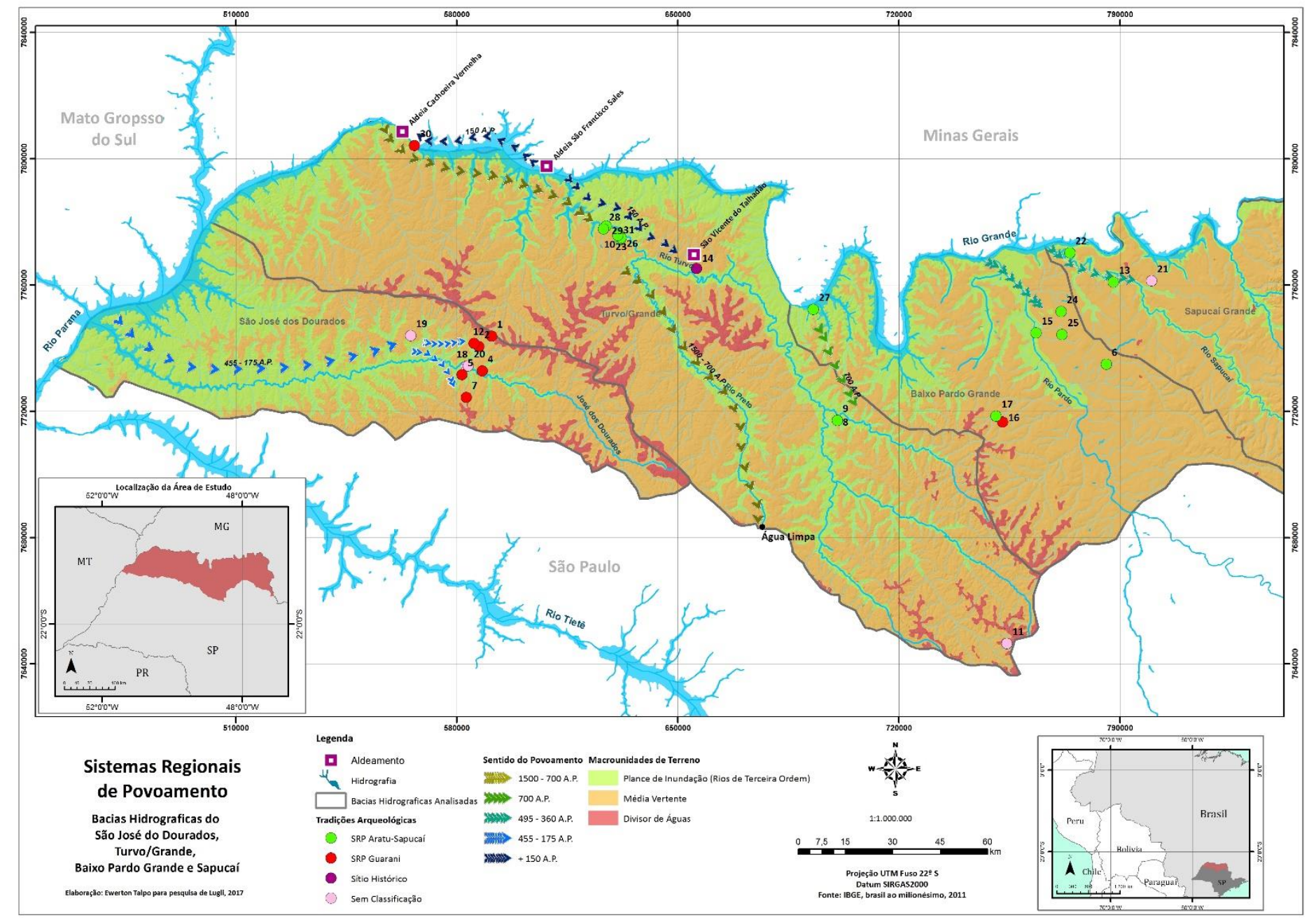

Fonte: IBGE. Confecção: Ewerton Talpo e David Pereira. 
CONSIDERAÇÕES FINAIS 
Neste tópico, apresentam-se as considerações finais acerca do percurso realizado dentro desta pesquisa de doutorado. Essa tese, intitulada "Arqueologia da Paisagem aplicada ao estudo dos sítios arqueológicos na bacia do Rio Turvo-Grande, região norte do estado de São Paulo", foi desenvolvida junto ao Programa de Pós-Graduação em Arqueologia, do Museu de Arqueologia e Etnologia, da Universidade de São Paulo (MAE-USP). A orientação desta pesquisa ficou a cargo do Prof. Dr. José Luiz de Morais até o memorial de qualificação, apresentado no ano de 2015, sendo procedida pela orientação da Profa. Dra. Neide Barrocá Faccio, até sua conclusão.

Procuramos nessas considerações finais realizar uma síntese dos elementos fundamentais do texto da tese, unindo ideias e gerando resposta ao problema apresentado na introdução. Salientamos que gerar resposta ao problema de pesquisa não implica em dizer que esgotou-se o assunto dessa tese. Intentou-se aqui, mostrar que esse estudo serviu para ampliar a compreensão sobre a ocupação humana no norte do estado de São Paulo e esclarecer a hipótese levantada.

A emolduração do texto iniciou-se com a confecção de um corpo teóricometodológico que permitiu a análise dos sítios arqueológicos trabalhados nesta pesquisa - sítio Barra de Ouro, sítio Porto Velho I, sítio Porto Velho II, sítio Menino Jesus e sítio Santa Filomena - em relação ao seu contexto regional, delimitado por quatro bacias hidrográficas situadas ao norte do estado de São Paulo ${ }^{80}$.

O corpo teórico-metodológico foi elaborado no Capítulo 1, com o intuito de abordar questões inerentes à arqueologia da paisagem. Para ampliar o conhecimento regional em arqueologia decorrente dessas questões, foi preciso realizar uma prospecção acerca do conceito de paisagem, de sua inserção na arqueologia e dos desdobramentos que a arqueologia da paisagem obteve, desde sua criação na década de 1970 até os dias atuais.

As linhas de pesquisas, que compõem o que conhecemos como "arqueologia da paisagem”, criaram ao final de nossa prospecção uma rede integrada de análise, que possibilitou confeccionar uma cartografia de ocupação da paisagem no norte do estado de São Paulo ${ }^{81}$. Pondera-se que essa cartografia é um organismo vivo que, nessa tese, materializou-se como um estágio do conhecimento e que no decorrer dos anos de pesquisa irá se tornar cada vez mais abrangente e complementar. Nesse processo - que é inerente

\footnotetext{
${ }^{80}$ Bacias do Turvo-Grande, Baixo Pardo-Grande, Pardo-Grande, Sapucaí-Grande e São José dos Dourados. ${ }^{81}$ Essa cartografia da paisagem arqueológica foi elaborada a partir do Capítulo 2 e esteve presente nos demais capítulos subsequentes.
} 
ao conhecimento acadêmico e científico - questões parcialmente respondidas aqui poderão ser confirmadas, complementadas ou refutadas.

Elaborar uma rede integrada de análise envolveu a junção de fios condutores denominados fenômenos geoambientais e socioespaciais, tecidos por meio das escalas e dimensões de uma paisagem arqueológica. Nesta primeira etapa de trabalho, gerou-se um aporte teórico-metodológico adequado para analisar o processo de ocupação e interação socioespacial do norte do estado de São Paulo, dentro do seu eixo histórico.

Num segundo momento, realizamos uma extensa revisão bibliográfica sobre o contexto arqueológico extrarregional e regional, bem como sobre o contexto etnohistórico regional direcionado à organização socioespacial indígena, durante o século XVIII ao XX. Essas informações foram compiladas no Capítulo 2 e formam a base de sustentação sobre a ocupação humana pretérita em nossa área de pesquisa.

A bibliografia mostrou que, de um modo geral, a ocupação indígena pré-colonial e colonial no norte do estado de São Paulo esteve associada a grupos humanos oriundos da região Centro-Oeste do país. Os dados fornecidos pelas pesquisas arqueológicas apontaram que a área de pesquisa representa uma ocupação tardia de um processo iniciado no vale do Araguaia e no alto Tocantins, por volta de 1000 anos antes do presente.

Tão importante quanto entender nosso contexto arqueológico regional foi entender o contexto arqueológico circunjacente. Nesse aspecto, bacias hidrográficas importantes como a bacia do médio-baixo Tietê, bacia do Mogi-Guaçu e bacia do Pardo foram analisadas com o propósito de entender a característica de seus sítios arqueológicos.

Na bacia do baixo Tietê, Maranca, Da Silva e Scabello (1994), localizaram-se sítios relacionados à tradição tupiguarani, que se apresentaram homogêneos em relação ao material lítico e cerâmico. Datações absolutas destes sítios mostraram tratar-se de ocupações contemporâneas estabelecidas em torno do ano 1200 antes do presente. No vale do médio Tietê, os sítios também estiveram relacionados a ocupações tupiguaranis. A datação absoluta para o sítio Gramado mostrou tratar-se de uma ocupação de aproximadamente 200 anos antes do presente (AFONSO, 2009).

Para a bacia do Rio Mogi-Guaçu, afluente do Rio Tietê, ocorre um predomínio de sítios arqueológicos filiados à tradição tupiguarani. Na região do alto-médio MogiGuaçu, Morais (1995) trabalhou com o sítio Franco de Godoy, descrevendo-o como uma aldeia pré-colonial de 1550 anos antes do presente. 
Para a bacia do Rio Pardo, afluente do Rio Grande, ocorre o predomínio de sítios arqueológicos filiados a grupos aratu-sapucaí e/ou uru. Segundo Afonso e Moraes (2007), essa ocupação situa-se numa faixa cronológica de 280 a 990 anos antes do presente.

Os dados fornecidos mostraram que os grupos ceramistas filiados às tradições do Centro-Oeste do país eram predominantes, dentro do estado de São Paulo, nas bacias do Rio Grande e do Rio Pardo. Teriam iniciado a ocupação nesses vales por volta de 1000 anos antes do presente, se estendendo até o período colonial, quando foram expulsos, aldeados e/ou dizimados pelos luso-brasileiros. Já os vales dos rios baixo-médio Tietê e Mogi-Guaçu, foram predominantemente ocupados por grupos ceramistas filiados à tradição tupiguarani, desde 1500 anos antes do presente até o período colonial.

A caracterização do contexto extra-regional estabeleceu uma correlação com o contexto arqueológico regional. Tal qual a ocupação das bacias circunjacentes, as bacias dos rios Turvo-Grande, Baixo Pardo-Grande, Pardo-Grande, Sapucaí-Grande e São José dos Dourados, formadores do CAR, mostraram-se complexas, tratando-se de antigos territórios indígenas que foram ocupados há pelo menos 1500 anos antes do presente ${ }^{82}$, até o período de invasão colonial, quando os nativos foram desterritorializados e subjugados pelos colonizadores.

Os objetivos da análise arqueológica regional foram o de ordenar e compilar informações dispersas sobre os sítios arqueológicos, dentro das escalas espacial e temporal. Informações como o nome do sítio, o corpo de água próximo, bacia hidrográfica em que se localiza, características gerais do sítio, localização UTM e cronologia foram aplicadas a 31 sítios arqueológicos, produzindo ao final informações cartográficas imprescindíveis à compreensão das ocupações pretéritas nessa região.

Primeiramente, todos os 31 sítios foram inseridos em base cartográfica, apresentando as bacias hidrográficas mencionadas e a cota altimétrica onde eles estão implantados. Essas informações geoambientais e socioespaciais possibilitaram demonstrar as características espaciais desses sítios, dentro de um plano sincrônico de ocupação regional.

Posteriormente, os sítios foram divididos em quatro cenários temporais arbitrários de ocupação, sendo eles: 1- período inicial de ocupação de grupos ceramistas

\footnotetext{
${ }^{82}$ Essa data faz referência à ocupação inicial do sítio Água Limpa. A data se mostrou bastante recuada no tempo em relação aos demais sítios localizados na área de pesquisa. Consideramos essa data como marco inicial de ocupação do CAR, no entanto, pondera-se que a data de 1000 a 700 anos antes do presente representa o período pelo qual grupos vindos do Centro-Oeste brasileiro adentraram o norte do estado, de forma mais sistemática.
} 
entre os anos de 1524 A.P. até 701 A.P.; 2- segundo cenário de ocupação entre os anos de 700 A.P. até 496 A.P.; 3- terceiro cenário de ocupação entre os anos de 495 A.P. até 361 A.P. e 4- o quarto cenário de ocupação entre os anos de 360 A.P. até 175 A.P. O último cenário de ocupação abrangeu o período de territorialização colonial e seus sítios podem relacionar-se aos dados etno-históricos levantados para esse período nessa região e regiões vizinhas.

A respeito dos dados etno-históricos levantados nessa pesquisa, ressalta-se que dizem respeito à organização socioespacial dos Kayapó Meridional. Esse grupo habitou uma extensa área, hoje conhecida como norte do estado de São Paulo, Triângulo Mineiro, sudeste de Goiás e sudoeste de Mato Grosso do sul, entre os séculos XVIII ao XX.

O objetivo da revisão bibliográfica sobre os dados etno-históricos foi o de aprofundar-se nas questões territoriais desse grupo indígena, buscando entender suas estratégias socioespaciais, em resposta ao período colonial e pós-colonial. O ordenamento dessas informações também pode ser confrontado com os dados arqueológicos regionais, que apresentaram datações contemporâneas aos séculos de ocupação kayapó.

Estabelecido um cenário espacial e temporal para o contexto arqueológico regional de pesquisa, no Capítulo 3 procurou-se contextualizar a área dos sítios arqueológicos trabalhados nessa tese, por meio de pesquisas de campo, laboratorial e de gabinete. Primeiramente, foi estabelecida a caracterização geoambiental do entorno desses sítios. Posteriormente, procurou-se entender como o processo de ocupação dessa paisagem, em período recente, impactou a matriz arqueológica desses sítios. Após o delineamento dessas questões, apresentou-se o programa de salvamento arqueológico que realizou intervenções nos depósitos arqueológicos, com o objetivo de extrair informações das características de implantação destes sítios, sua correlação com o entorno e as características de seus materiais.

Em termos de escala regional, a bacia hidrográfica do Rio Turvo-Grande, que acolhe os sítios arqueológicos aventados nesta pesquisa, possui uma singularidade biogeográfica: compreende o contato entre os biomas cerrado e mata atlântica. Esta área de transição forma um mosaico fitogeográfico heterogêneo, pontilhado por cerrados, cerradões e floresta tropical, que no passado formaram um suporte geoambiental para diferentes populações humanas.

Os quatro sítios pré-coloniais trabalhados localizaram-se entre a intersecção de planícies baixas, próximas às margens de rios e córregos, e colinas amplas próximas a topos de interflúvios. O embasamento rochoso de basalto nos fundos de vale, leito dos 
rios e córregos, e de arenito nas vertentes e topos, possibilitou a formação de um relevo com topos extensos e aplainados, bem como de vales abertos e vertentes retilíneas. Olatossolo vermelho, próximo aos canais de água como o Rio Grande e o Rio Turvo, acolheu a Floresta Estacional Semidecidual.

Esse contexto geoambiental abrigou três sítios pré-coloniais a céu aberto (Barra de Ouro, Porto Velho I e Porto Velho II), com baixa densidade de material arqueológico e outro (Menino Jesus), com alta densidade e variabilidade de material arqueológico. A ocorrência de um restrito quadro de objetos arqueológicos nos três primeiros sítios acima citados pode estar relacionada a locais de atividades específicas, como acampamentos sazonais, acampamentos noturnos, atividades de roça ou pontos de caça ou coleta (FACCIO, 1998; GIRALDIN, 1997; NOELLI, 1993; WUST, 1990).

O material arqueológico obtido para o sítio Barra de Ouro foi predominantemente formado por coleção de material lítico lascado. Essa característica diferencia essa ocupação das demais, onde ocorreu o predomínio de uma coleção de fragmentos cerâmicos. As matérias-primas mais comuns, identificadas para a coleção do sítio Barra de Ouro, foram o silexito, arenito silicificado e o quartzo. Afloramentos desses três tipos de matéria-prima foram detectados na proximidade, junto com o basalto, que foi o tipo de rocha em que foi confeccionado o único instrumento polido detectado no sítio. A grande frequência da categoria "lasca" e de materiais em estado bruto (seixos, blocos de silexito e quartzo etc.), nesse contexto, pode indicar que o local se tratava de uma área de coleta de matéria-prima e de atividades de lascamento iniciais. Não foi possível determinar se a área foi usada para outra (s) atividade (s), além das já mencionadas.

Os sítios Porto Velho I e Porto Velho II distam, um do outro, apenas 1.600 metros, e tanto sua disposição topográfica, quanto a característica e intensidade do material arqueológico, são muito semelhantes. Predominantemente, esses dois sítios apresentaram algumas dezenas de fragmentos de cerâmica do tipo liso, com pouco ou nenhum material lítico, dispersos sobre a média-baixa vertente, distante aproximadamente 100 metros do Rio Grande.

No caso dos dois sítios citados, sugere-se tratar-se de acampamentos ou abrigos temporários e sazonais, respaldando-se na baixa quantidade e variabilidade do material arqueológico, bem como na baixa densidade de sua dispersão pela paisagem. A proximidade com o Rio Grande pode ser um fator geográfico preponderante para essas áreas de atividades, uma vez que abrigos próximos às margens de rios (POSEY, 1979) ou 
áreas de atividades específicas como a pesca (MORAIS, 1999; MORALES, 2007), interconectadas com áreas de habitação, pressupõem um modelo de interação ambiental já bastante conhecido (BINFORD, 1982).

Ponderamos que alguns relatos históricos, como os compilados por Florence (1875), citam a existência de pequenos ranchos kayapós que podem correlacionar-se aos dados arqueológicos mencionados. $\mathrm{O}$ autor descreve estes ranchos como situados acima da foz do Rio Tietê com o Rio Paraná, de construção muito efêmera, apenas formada por folhas de palmeiras apoiadas em forquilhas de paus. Seu relato menciona a proximidade dessas construções com o conjunto de cachoeiras denominado Salto de Urubupungá. Outro relato compilado por Barbosa (1918) informa que os Kayapó que habitavam a aldeia de Água Vermelha, localizada na margem mineira do Rio Grande, faziam pequenas roças nas terras paulistas desabitadas à margem esquerda deste rio, com o objetivo de cevar a caça. Essa estratégia socioespacial de ocupação do espaço poderia deixar vestígios discretos no solo, como os encontrados nos sítios supracitados. Os dados arqueológicos correlacionados aos dados etno-históricos trazem possibilidades interpretativas do uso do espaço para os sítios Porto Velho I e II.

As grandes aldeias que serviriam de habitação às populações indígenas précoloniais, muitas vezes estão entrelaçadas com acampamentos e locais de atividades específicas e podem ajudar na compreensão da ocupação socioespacial, em termos ecológicos. Questões de suprimento, disposição de caça, fertilidade do solo, coleta de alimentos, áreas de descanso, constituem um desenvolvimento adequado às estratégias de subsistência de grupos agricultores estabelecidos em grandes aldeias (POSEY, 1979).

Nesse modelo de ocupação, o sítio Menino Jesus, apresentando-se como uma ocupação de $600 \pm 70$ A.P à $715 \pm 55$ A.P. (FACCIO, 2015), poderia ser considerado como um sítio-habitação. Apresentou configuração linear, sendo identificadas pelo menos duas linhas de deposição arqueológica, em ambas as margens do Córrego Menino Jesus até sua desembocadura com o Rio Grande. No entanto, existe uma continuidade na dispersão de fragmentos cerâmicos até a margem do Rio Grande, que não pôde ser totalmente prospectada por se tratar de uma área represada pela UHR-Marimbondo. Essas linhas de deposição arqueológica sofreram processos pós-deposicionais, como erosão fluvial, erosão pluvial, agricultura mecanizada e atividades de pastoreio. Por se tratar de uma área de depleção, o deslocamento incessante de subida e descida das águas da represa pode ter deslocado e concentrado os materiais arqueológicos da baixa-média vertente para o fundo de vale, formando essas linhas paralelas ao corpo d’água. 
Mesmo considerando os efeitos pós-deposicionais e seus impactos na morfologia do sítio em apreço, as constantes monitorias realizadas anualmente, bem como os trabalhos de escavação, nos mostraram que, se houve o deslocamento de materiais arqueológicos por força erosiva, este por sua vez não foi o suficiente para reconfigurar o sítio de forma tão intensa. Acreditamos que sua predisposição a formar linhas paralelas ao córrego Menino Jesus é mais um efeito comportamental de seus antigos habitantes do que dos agentes e processos de formação pós-deposicional.

A margem esquerda do Córrego Menino Jesus abriga as maiores concentrações de fragmentos cerâmicos e material lítico lascado, enquanto na margem direita documentou-se a dispersão de material lítico polido e fragmentos de cerâmica em menor quantidade, embora se estendendo linearmente em uma área contínua maior, até a margem do Rio Grande.

Salienta-se que os estudos de Wust (1983) identificaram seis sítios arqueológicos em Goiás, filiados à tradição uru, que apresentaram concentrações cerâmicas dispostas linearmente, semelhantes ao sítio Menino Jesus. Segundo a autora, essas estruturas são compostas por duas a seis concentrações alinhadas ao longo de um curso de água e foram interpretadas como sítios de atividade limitada. Essa interpretação baseia-se nas características dos vestígios arqueológicos apresentados como: reduzido tamanho das concentrações, pequena quantidade de artefatos, ausências de modificação da coloração da solo e pequena espessura do refugo, indicando que esses sítios foram ocupados por uma comunidade maior, que nesses locais executavam apenas algumas atividades de ciclo curto, no qual somente poucos recursos são aproveitados.

Pondera-se que, diferentemente da interpretação da autora para o contexto arqueológico goiano, o sítio Menino Jesus demonstra características de um sítio habitação e não de um sítio de atividade limitada.

Parte-se do pressuposto de que o norte de São Paulo não apresentou nem a densidade, nem a configuração, dos sítios estudados por Wust (1983) e RobrahnGonzalez (1996) no Centro-Oeste. Como área periférica de ocupação de populações ceramistas associadas aos Jê do Brasil Central, o norte de São Paulo apresentou sítios menores e sem a configuração circular, característico desses grupos. Com base nessa informação, o sítio Menino Jesus, em seu contexto arqueológico regional, apresenta-se como um dos sítios de maior densidade e variabilidade de materiais arqueológicos. Por outro lado, instala-se em local estratégico, com acesso a uma gama de recursos como: 1cascalheira com a presença de seixos em silexito e quartzito, aptos ao lascamento; 2- 
afloramento de basalto, apto à confecção de ferramentas polidas; 3- jazidas de argila na coloração preta e branca, aptas à confecção de utensílios de cerâmica e produção de engobo branco; 4-nascentes de água aflorando dentro e no entorno da área de ocupação pretérita; 5- rio navegável e de alta piscosidade, por situar-se próximo ao salto/cachoeira do Marimbondo. Essas características apresentam requisitos elementares para a interpretação desse sítio como uma antiga área de habitação.

A análise dos fragmentos cerâmicos coletados e georreferenciados mostrou características semelhantes à da tradição aratu-sapucaí, apresentando cerâmica predominantemente lisa, com incisão na borda paralela ao lábio, disco de fuso e formas conjugadas. Em um caso, fragmentos cerâmicos pertencentes a um mesmo vaso nos possibilitaram gerar sua reconstituição parcial. A morfologia desse vaso apresentou-se como esférico ovalóide, com $30 \mathrm{~cm}$ de altura por $40 \mathrm{~cm}$ de largura, semelhante a formas documentadas por Wust $(1983,1990)$ para o Centro-Oeste.

No entanto, em quase $2 \%$ dos casos, os fragmentos de cerâmica apresentaram engobo e/ou pintura em sua superfície, característicos da tradição tupiguarani. Esse fenômeno é recorrente na região, como já comentamos, e nos mostra que interações culturais ocorreram no passado. Essas interações podem ter acontecido, ao menos, de três formas diferentes ou interdependentes.

A primeira seria a que Zedeño (1997) chamou de recuperação, ou seja, a usurpação de um território ocupado por um grupo, por outro grupo culturalmente diferenciado. Neste caso, fragmentos de cerâmica de tradições distintas seriam fruto de ocupações em épocas distintas. O uso de técnica de datação por termoluminescência (TL) entre esses dois tipos de cerâmica pode determinar se a hipótese é plausível e qual ocupação seria a mais antiga.

Uma segunda hipótese envolveria a interação entre esses grupos e suas fronteiras. Assim, formariam redes de interações sociais baseadas em trocas regulares de materiais, das quais os vasos cerâmicos fizeram parte. Nessa perspectiva, fronteiras culturais seriam efêmeras, permitindo o fluxo de materiais e pessoas nos dois sentidos, construindo conexões intergrupos. Neste caso, o uso de técnicas arqueométricas aplicadas aos fragmentos de cerâmica solucionariam algumas questões importantes. Entre elas, se há correlação dos fragmentos pigmentados com as jazidas de argila prospectadas na área do sítio e se há diferença estrutural e química entre as pastas dos fragmentos cerâmicos filiados à tradição aratu-sapucaí e à tradição tupiguarani. 
A terceira hipótese - e talvez a mais difícil de se detectar por meio das técnicas arqueológicas - seria o compartilhamento de estilos entre grupos culturais distintos. Assim, a variabilidade dos materiais cerâmicos não estaria relacionada nem à reocupação territorial, nem às redes de troca, mas a outra forma elementar de interação - a matrimonial. Neste caso, a aliança entre grupos dar-se-ia por meio de casamentos interétnicos (VIVEIROS DE CASTRO, 2002). Redes regionais de casamentos sugeririam a movimentação de pessoas em circuitos cerimoniais, nos quais oleiras tratariam de compartilhar o seu habitus na confecção da cerâmica com o grupo acolhedor. As técnicas arqueométricas poderiam avaliar os elementos químicos presentes nos pigmentos dos engobos e pinturas das superfícies cerâmicas e correlacionar as fontes de matérias-primas (blocos de hematita, jazidas de argila branca etc.) prospectadas no sítio e na área de entorno. Caso haja correspondência entre pigmentos retirados dos fragmentos cerâmicos com as matérias-primas locais, o material pode ter sido confeccionado por oleiras desse sítio, indicando relações além das trocas de materiais.

Estas hipóteses surgiram no decorrer da pesquisa e ainda não foram estudadas sistematicamente, por questões de tempo e de recorte teórico-metodológico. No entanto, propõe-se a continuidade desse tema em estudos futuros de pós-doutorado, onde se pretende aprofundar-se nas técnicas arqueométricas, produzindo novos dados sobre o sítio Menino Jesus. A aplicação das técnicas arqueométricas possibilitará analisar mais profundamente questões de âmbito geográfico (produção e distribuição das cerâmicas), gestual (produção e acabamento das cerâmicas), sociológicas (interações sociais e tecnológicas entre grupos) e funcionais.

O quinto sítio trabalhado foi o Santa Filomena. Trata-se de um sítio histórico do período colonial brasileiro, que apresentou muros em estrutura de pedra, formato quadrangular, cruzeiro em seu centro e 22 montes formados por rochas basálticas, interpretados pela equipe de pesquisa como túmulos de antigo cemitério. Esse sítio constitui-se como uma chave importante para o entendimento da ocupação regional do norte do estado de São Paulo (FACCIO, 2015). Os dados arqueológicos correlacionados aos relatos orais e informação histórica revelou tratar-se, esse sítio, de uma antiga colônia ou aldeamento chamado São Vicente do Talhadão. Sua data de fundação ainda não é conhecida, mas as informações apuradas mostram que o mesmo foi construído após o ano de 1860 e antes do ano de 1913, pelo Pe. Macedo em missão evangelista. Nesse período, esse local funcionou como aldeamento para os Kayapó e centro propulsor de colonização do norte do estado (FACCIO, 2015). 
No Capítulo 4, a proposta foi estabelecer a conexão de toda informação apurada na tese, com base no conceito de sistema regional de povoamento, desenvolvido por Morais (1999-2000). O conceito possibilitou intermediar as características da variabilidade dos materiais arqueológicos, com a organização socioespacial dos assentamentos/áreas de atividades em nível regional.

A conexão das informações contidas nessa tese possibilitou definir alguns padrões de ocupação da paisagem. Considera-se que a síntese formulada no Capítulo 4 contribuiu com a compreensão do processo de habitar as paisagens do norte do estado, desde o período pré-colonial até o período histórico, servindo de arcabouço para eventuais estudos futuros sobre o tema.

Nesta pesquisa foram identificados três sistemas regionais de povoamento, sendo dois predominantemente indígenas e o terceiro associado à colonização do norte do estado de São Paulo e regiões adjacentes.

A ocupação territorial de povos indígenas agricultores ceramistas no norte do estado de São Paulo inicia-se por volta do século XI da Era Cristã. As ocupações mais antigas apresentaram fragmentos de recipientes e utensílios cerâmicos, associados aos grupos vindos do Centro-Oeste do Brasil. Esses grupos, anteriormente, haviam passado por um processo sistemático de interação/fusão cultural no centro-leste de Goiás e essas características foram detectadas, em parte, em nossa região de pesquisa.

A ocupação humana associada a grupos jês do Brasil Central se estendeu em nossa área de pesquisa até o período histórico, quando da penetração de colonizadores por estes sertões a caminho das jazidas auríferas de Goiás, durante todo o século XVIII e meados do século XIX. Nesta época, havia uma grande nação indígena que estendia seus domínios territoriais do centro-leste de Goiás até o norte do estado de São Paulo, leste de Mato Grosso do sul ao oeste de Minas Gerais. Esta nação ficou conhecida pelos colonizadores como Kayapó e boa parte de seu território se confunde com as áreas onde sítios Aratu-Sapucaí foram detectados. Quando as datações desses sítios coincidem com a faixa cronológica de domínio kayapó é possível associar estas ocupações.

$\mathrm{Na}$ bacia do rio São José dos Dourados, na zona oeste do CAR, grupos tupiguaranis, provavelmente guarani vindos de Mato Grosso do Sul, ocuparam discretamente os espigões que dividiam esta bacia da bacia do Rio Tietê e do Rio Grande. Provavelmente, estes grupos estavam migrando para o leste do Brasil em busca de novos territórios. O vazio territorial deixado pelo extermínio e aldeamento dos grupos kayapós nessa região, durante todo o século XIX, pode ter contribuído para esses movimentos 
guaranis. Sítios arqueológicos filiados à tradição tupiguarani no alto Paraná e baixo Tietê, que apresentaram cronologia mais recuada no tempo, grande extensão e variabilidade de material arqueológico, instalação em vertentes próximas a grandes rios, mostraram tratarse de um contexto de ocupação socioespacial, diferente a esses pequenos sítios guaranis mais recentes.

Finalmente, os três aldeamentos detectados nessa pesquisa inserem-se em um mesmo contexto histórico. Foram fundados por padres da Congregação da Missão, que em suas incursões missioneiras pelos sertões do oeste mineiro e norte paulista foram fundando aldeamentos para reduzir os Kayapó, antigos habitantes desta região, e iniciar um processo de colonização por estas paragens. Notou-se um mesmo padrão de assentamento para estes aldeamentos, próximos a três grandes saltos/cachoeiras, como a Cachoeira dos Índios, Vermelha e do Talhado ou Talhadão. É provável que estes missionários tenham procurado locais próximos às antigas aldeias kayapós e seu sistema de caminhos, como o fizeram os primeiros missionários do século XVI com os grupos tupis no planalto paulistano. 
REFERÊNCIAS 
AB`SABER, A. N. Domínios morfoclimáticos e províncias fitogeográficas do Brasil. Orientação, v. 3, p. 45-48, 1967.

Paleoclimate and paleoecology of Brazilian Amazonia. In: Biological diversification in the tropics: proceedings, fifth international symposium of the Association for Tropical Biology, held at Macuto Beach, Caracas, Venezuela, and February 8-13, 1979/edited by GT Prance. New York: Columbia University Press, 1982.

Brasil, paisagens de exceção: o litoral e o Pantanal Matogrossense, patrimônios básicos. Ateliê Editorial, 2006.

AFONSO, M.C. Arqueologia Jê no Estado de São Paulo. Revista do Museu de Arqueologia e Etnologia, n. 27, p. 30-43, 2017.

Um painel da arqueologia pré-histórica no Estado de São Paulo: os sítios cerâmicos. Especiaria: Cadernos de Ciências Humanas, v. 11, n. 20, 21, 2009.

AFONSO, M. C.; DE MORAES, C. A. O sítio Água Branca: interações culturais dos grupos ceramistas no norte do Estado de são Paulo. Revista do Museu de Arqueologia e Etnologia, v. 15, p. 16, 2005.

AFONSO, M.C.; SALLUM, M.; LOPES, M. 2009. Ocupações ceramistas Tupi e Gê em São Paulo: espacialização e cronologia. In: XV Congresso Sociedade de Arqueologia Brasileira. Trabalhos completos. Belém: Sociedade de Arqueologia Brasileira (SAB), 815.

ALTENFELDER SILVA, F. Informes preliminares sobre a arqueologia de Rio Claro. Programa Nacional de Pesquisas Arqueológicas - Resultados Preliminares do Primeiro Ano / 1965- 1966. Museu Paraense Emilio Goeldi, Publicações Avulsas, 6: 7988, 1967.

ALVES, T. Paisagem - em busca do lugar perdido. Finisterra: Revista portuguesa de geografia, v. 36, n. 72, p. 67-74, 2001.

ALVES, M. A. Assentamentos e Cultura Material Indígena Anteriores ao Contato no Sertão da Farinha Podre, MG, e Monte Alto, SP. Tese apresentada para o concurso de Livre Docência, São Paulo, Universidade de São Paulo, 2009.

ALVES, M. A.; GOULART, E.; DIAS DE ANDRADE, F. R. Cadeia Operatória, Sistema Tecnológico e Análise Arqueométrica nos Assentamentos Cerâmicos dos Vales do Paranaíba, Minas Gerais e Turvo, São Paulo, Brasil. Cuadernos del Instituto Nacional de Antropología y Pensamiento Latinoamericano-Series Especiales, v. 1, n. 2, 2014.

ANTHONY, D. W. The horse, the wheel, and language: how Bronze-Age riders from the Eurasian steppes shaped the modern world. Princeton University Press, 2007.

ARAÚJO, A.G.M. Teoria e método em arqueologia regional: um estudo de caso no alto Paranapanema, Estado de São Paulo. 2001. Tese de Doutorado. 
2002.

Destruído pelo arado. Arqueologia de superfície e armadilhas do,

Prospecção Arqueológica e Resgate para implantação de loteamento, município de Rio Claro - SP. Relatório Final, 2014.

AYRES DE CASAL, M. Corographia Brasilica ou Relação Histórico-Geographica do Brasil. Rio de Janeiro, 1845

BALÉE, W. Sobre a indigeneidade das paisagens. Revista de Arqueologia, v. 21, n. 2, 2008.

BALÉE, W. L.; ERICKSON, C. L. Time and complexity in historical ecology: studies in the neotropical lowlands. Columbia University Press, 2006.

BALFET, H. Observer l'action technique: des chaînes opératoires, pour quoi faire?. Editions du Centre national de la recherche scientifique, 1991.

BARBOSA, A. S. Cayapó e panará [manuscrito]. 1918.

BARTH, F. Ethnic groups and boundaries: The social organization of culture difference. (Results of a symposium held at the University of Bergen, 23rd to 26th February 1967.). Universitetsforlaget, 1969.

BARROCÁ, D.; RAMAZZINA, A.A.; FACCIO, N.B. Cacos de Vidro: Um estudo no Sítio Arqueológico Santa Filomena. 2015. Artigo apresentado para obtenção de título de Especialista no o curso de Pós-Graduação Latu Sensu em Arqueologia, História e Sociedade. Universidade de Santo Amaro, UNISA.

BÉLO, T.P. Estudo tecnológico e das cadeias operatórias da cultura material lítica e cerâmica, coletada nos anos 1995, 1996 e 2000, no sítio Água Limpa, município de Monte Alto, SP. 2007. Tese de Doutorado. Universidade de São Paulo.

BERTRAND, G.; BERTRAND, C. Uma geografia transversal e de travessias: o meio ambiente através dos territórios e das temporalidades. Maringá: Massoni, 2007.

BINFORD, L. R. "The archaeology of place." Journal of Anthropological Archaeology 1.1 5-31. 1982

Em Busca do Passado: a descodificação do registro arqueológico, Fórum da História. Publicações Europa-América, tradução de João Zilhão, p. 304. 1983.

BOAS, F. Kwakiutl Ethnography. Helen Codere, ed. Chicago \& London: University of Chicago Press, 1966

BONNEMAISON, J. Viagem em torno do território. Geografia cultural: um século (3). Rio de Janeiro: EdUERJ, p. 83-131, 2002. 
BOURDIEU, P.; ORTIZ, R. O campo científico. Pierre Bourdieu: sociologia. São Paulo: Ática, p. 122-155, 1983.

BOURDIEU, P. A identidade e a representação: elementos para uma reflexão crítica sobre a ideia de região. O poder simbólico, v. 2, 1989.

BORGES, M.C. A história agrária em Sant'Anna do Paranahyba, sul de Mato Grosso: os Cayapó por entre roças, fazendas e aldeamentos. Anais do XVI Encontro Regional de História da Anpuh - Rio. 2014

BORGONOVI, M.; CHIARINI, J. V. Cobertura vegetal do Estado de São Paulo: ILevantamento por fotointerpretação das áreas cobertas com cerrado, cerradão e campo, em 1962. 1965.

BOSI, A. Dialética da colonização. São Paulo: Companhia das letras, 1993.

BOSI, E. O tempo vivo da memória: ensaios de psicologia social. Ateliê editorial, 2003.

BROCHADO, J.P. A Expansão dos Tupi e da Cerâmica da Tradição Policrômica Amazônica. São Paulo: Dédalo 1991. p.65-82.

BROCHADO, J. P. et al. Arqueologia brasileira em 1968: um relatório preliminar sobre o Programa Nacional de Pesquisas Arqueológicas. Publicações Avulsas do Museu Paraense Emílio Goeldi, n. 12, p. 3-33, 1969.

BROCHADO J. P.; LA SALVIA. Cerâmica Guarani. Porto Alegre: Posenato Arte \& Cultura, 1989.

BUENO. J.F.O. Simples narração da viagem que fez ao Rio Paraná o tesoureiro-mór da Sé d'esta cidade de S. Paulo [...]. Revista do Instituto Histórico Geográfico Brasileiro. Rio de Janeiro, Terceira edição, p. 139-151, 1908.

BUTTIMER, A. Lar, horizontes de alcance e o sentido de lugar/Place, reach, and the sense of place. Geograficidade, v. 5, n. 1, p. 4-19, 2015.

BUTZER, K. W. Archaeology as human ecology: method and theory for a contextual approach. Cambridge University Press, 2006.

CALDARELLI, S.B. Pesquisa arqueológica em projetos de infraestrutura: a opção pela preservação. Revista do Patrimônio, v. 33, p. 153-174, 2007.

CAMPOS, A. P. de. Breve notícia do gentio bárbaro que há na derrota das minas de Cuiabá e seu recôncavo, na qual declara-se os reinos [...] Revista Trimensal do Instituto Historico Geographico e Ethnographico do Brasil tomo XXV, $3^{\circ}$. Trimestre, p. 437-449, 1862.

CAMPOS, E. A vila de São Paulo do Campo e seus caminhos. Revista do Arquivo Municipal/Departamento do Patrimônio Histórico, p. 11-34, 2006. 
CARR, C. The nature of organization of intrasite archaeological records and spatial analytic approaches to their investigation. Advances in archaeological method and theory, p. 103-222, 1984.

CARRIER, J. G. Exchange. Handbook of Material Culture. London, UK: Sage, 2006.

CASSETI, V. Ambiente e Apropriação do Relevo. São Paulo: Contexto, 1991.

. Fisiologia da paisagem. In CASSEITI, V. Geomorfologia. Disponível em www. funape. org. br/geomorfologia. Download em, v. 20, n. 08, 2006.

CAVALCANTE, T.L.V. Colonialismo, território e territorialidade: a luta pela terra dos Guarani e Kayowá em Mato Grosso do Sul. 2013. 470 f. Teses (doutorado) - Universidade Estadual Paulista Júlio de Mesquita Filho, Faculdade de Ciências e Letras de Assis, 2013.

CHMYZ, Igor. A Tradição Tupiguarani no Litoral do Estado do Paraná. Curitiba:

Círculo de Estudos Bandeirantes, 2002, p.71-95.

CHMYZ, I. Monitoramento, uma abordagem complementar ao salvamento arqueológico. Arqueologia, Curitiba, v. 8, p. 61-76, 2004.

CENTRO DE PESQUISA METEOROLOGICAS E CLIMATICAS APLICADAS A AGRICULTURA. Clima dos municípios paulista. Disponível em: http://www.cpa.unicamp.br/outras-informacoes/clima_muni_229.html. Acesso em: 15 de Fev. 2015.

COMISSÃO GEOGRÁFICA E GEOLÓGICA DO ESTADO DE SÃO PAULO (1913) - EXPLORAÇÃO DO RIO GRANDE E DE SEUS AFLUENTES (1910). São Paulo.

CHRISTOFOLETTI, A. Geomorfologia. São Paulo: Edgard Blucher, 1980.

CLARKE, D. Archaeology: the loss of innocence. Antiquity, v. 47, n. 185, p. 6-18, 1973.

COLIN, S. Técnicas construtivas do período colonial - I, Coisas da Arquitetura, 2010.

COLWELL-CHANTHAPHONH, C. Myth of the Anasazi: archaeological language, collaborative communities, and the contested past. Public Archaeology, v. 8, n. 2-3, p. 191-207, 2009.

CORRÊA, R. L.; ROSENDAHL, Z. Paisagens, texto e identidade. EDUERJ, 2004.

COSGROVE, D. A Geografia Está em Toda Parte: Cultura e Simbolismo nas Paisagens Humanas. In: CORREAA, Roberto Lobato; ROSENDAHL, Zeny (Org). Paisagem, Tempo e Cultura. Rio de Janeiro: EdUERJ, 2004. p. 92-123.

DAVID, B; THOMAS, J. Landscape Archaeology: Introduction. In: B. DAVID e J. THOMAS (Eds.). Handbook of Landscape Archaeology. Walnut Creek: LEFT COAST PRESS. Pp. 27-43. 2008. 
DE ABREU, A. Os tesouros históricos do Talhadão. Diário da Região. São José do Rio Preto. 7 de ago, 2011.

DE OLIVEIRA, J. E.; VIANA, S. A. O centro-oeste antes de Cabral. Revista Usp, n. 44, p. 142-189, 1999-2000.

DESROSIERS, S. Sur le concept de chaîne opératoire. Editions du Centre national de la recherche scientifique, 1991.

DIAS JÚNIOR, O. Breves notas a respeito das pesquisas no sul de Minas Gerais. Resultados preliminares do quarto ano de pesquisas - PRONAPA: 1968-1969, Museu Paraense Emílio Goeldi, Belém, Publicações Avulsas, 15, p. 133-148, 1971.

Nota prévia sobre as pesquisas arqueológicas em Minas Gerais. Resultados preliminares do quinto ano de pesquisas - PRONAPA: 1969-1970, Museu Paraense Emílio Goeldi, Belém, Publicações Avulsas, 26, p. 105-116, 1974.

DUNNELL, R. C., \& SIMEK, J. F. (1995). Artifact size and plowzone processes. Journal of Field Archaeology, 22(3), 305-319.

ERICKSON, C. L; DARLING J. A. Landscapes of movement. Trails, paths and roads in anthropological perspectives. Philadelphia: University of Pensylvania Museum of Archaeology and Anthropology. Pp. 42-60. 2009.

ERICKSON, C. L. Agency, causeways, canals and the landscapes of everyday life in the Bolivian Amazon. In: J.E. SNEAD; C.L. ERICKSON e J. A. DARLING. Landscapes of movement. Trails, paths and roads in anthropological perspectives. Philadelphia: University of Pensylvania Museum of Archaeology and Anthropology. Pp. 204-231. 2009.

FACCIO, N. B. Estudo do sítio arqueológico Alvim no contexto do projeto Paranapanema. 1992. Dissertação de Mestrado. Faculdade de Filosofia, Letras e Ciências Humanas da Universidade de São Paulo.

Arqueologia do cenário das ocupações horticultoras da capivara, baixo Paranapanema-SP. 1998. Tese de Doutorado. Faculdade de Filosofia, Letras e Ciências Humanas da Universidade de São Paulo.

Programa de Diagnóstico Arqueológica na Área de Ampliação do plantio de cana-de-açúcar da Usina Moema Açúcar e Álcool Ltda. Relatório final. 2009.

Arqueologia Guarani na Área do Projeto Paranapanema: Estudo dos

Sítios de Iepê, SP. Relatório apresentado para o concurso de Livre Docência, São Paulo, Universidade de São Paulo, 2011.

Paisagens dos Sítios Arqueológicos no Município de Iepê, Estado de São Paulo, Brasil. Presidente Prudente, no prelo [primeira versão, excerto]

FACCIO, N. B. et. al. Programa de Prospecção Arqueológica na Área de Ampliação do plantio de cana-de-açúcar da Usina Moema Açúcar e Álcool Ltda. Relatório final. 2012. 
FACCIO, N. B. et. al. Programa de Salvamento Arqueológico na Área de Ampliação do plantio de cana-de-açúcar da Usina Moema Açúcar e Álcool Ltda. Relatório final. 2015.

FELICÍSSIMO, M. P. et al. Estudos arqueométricos de cerâmicas indígenas précoloniais das lagoas do castelo e vermelha, localizadas no Pantanal Sul-MatoGrossense. 2004. Tese de Doutorado. Área interunidades em Ciência e Engenharia de Materiais da Universidade de São Paulo.

FERGUSON, T. J.; COLWELL-CHANTHAPHONH, C. Landscapes of a living past. In: History is in the land. Multivocal tradition in Arizona's San Pedro Valley. Pp. 189227. 2006.

FERNANDES, S. C. G. Contribuição Para o Estudo da Tradição Aratu-Sapucaí, Estudo de Caso: O sítio arqueológico de Água Limpa, Monte Alto - São Paulo. Xingó, número 1 , dezembro de 2001.

FERREIRA, J.P. et al. Enciclopédia dos municípios brasileiros. Vol. XXXVI. Rio de Janeiro: IBGE, 1958.

FLEMING, A. Post-processual landscape archaeology: a critique. Cambridge Archaeological Journal, v. 16, n. 03, p. 267-280, 2006.

FLORENCE, H. Esboço da viagem feita pelo Sr. de Langsdorff no interior do Brasil, desde setembro de 1825 até março de 1829. Revista do Instituto Histórico e Geográfico Brasileiro, p. 355-469, 1875.

FUNDAÇÃO FLORESTAL. Plano de Manejo da Estação Ecológica Paulo de Faria. Disponívelem:http://fflorestal.sp.gov.br/files/2012/01/EEPaulodeFaria/EncartesPMEEP F/ENCARTE3fim1.pdf. Acesso em: 23 Julho de 2015.

FURNAS.

Disponível

em:

http://www.furnas.com.br/hotsites/sistemafurnas/usina_hidr_marimbondo.asp Acesso em: 18 de Abril de 2016.

GALLAIS, J. Alguns aspectos do espaço vivido nas civilizações do mundo tropical. Espaço e Cultura, UERJ, N. 6, JUL/DEZ DE 2002

GAMBLE C. Hidden landscapes of the body. Handbook of Landscape Archaeology, Left Coast Press, Walnut Creek, CA, 2008.

GIRALDIN, O. Cayapó e Panará: luta e sobrevivência de um povo Jê no Brasil Central. Campinas, São Paulo, Brasil: Editora da UNICAMP, 1997.

Renascendo das cinzas. Um histórico da presença dos Cayapó-Panará em Goiás e no Triângulo Mineiro. Sociedade e cultura, v. 3, n. 1, 2007.

GOULART, E. P. Técnicas instrumentais para a caracterização mineralógica e microestrutural de materiais cerâmicos arqueológicos. CANINDÉ-Revista do Museu de Arqueologia de Xingó, UFS, n. 4, p. 249-271, 2004. 
GRACE, R. The "Chaine Operatoire" approach to lithic analysis. Archaeometry. Publicação Eletrônica, Oslo, 1996. 24p.

GRAVES, M. W. Analyzing and interpreting ceramic production and distribution in the American southwest, Reviews in Anthropology, 29:3, 253-272, 2001.

GUERRA, A. T. Dicionário de Geomorfologia. Rio de Janeiro: FIBGE, 1993.

HAESBAERT, R. Território, territorialidade e multiterritorialidade. Rio de Janeiro, 2005.

HEIDEGGER, M. Bauen, Wohnen, Denken (1951), Vortäge und Aufsätze, G. Neske, Pfullingen, 1954.

HEILEN, M.P. An Archaeological Theory of Landscapes. The University Arizona. 2005.

HODDER, I. Style as historical quality. The uses of style in archaeology, p. 44-51, 1990.

HODDER, I. Catalhoyuk: The Leopard's Tale: Revealing the Mysteries of Turkey's Ancient'town'. Thames \& Hudson, 2011.

HOLLENBACK, K. L. Landscapes. Behavioral archaeology: principles and practice, p. 186-193, 2010.

HOLLOWELL, J.; NICHOLAS, G. A critical assessment of ethnography in archaeology. Ethnographic archaeologies: reflections on stakeholders and archaeological practices. AltaMira Press, Lanham MD, p. 63-94, 2008.

HUMBOLDT, Alexander von. Quadros da natureza. São Paulo: WM Jackson Inc, v. 1 e 2,1952 .

INÁCIO FILHO, G.; FARIA, L.A.S.B.; SILVA, L.R. Preservação da Memória e do Patrimônio Institucional de Educação Católico de Campina Verde-MG. 2007. Disponível http://www.fae.ufmg.br/portalmineiro/conteudo/externos/4cpehemg/Textos/pdf/7e_2.pd f.Acesso em: 18 Novembro de 2017.

INGOLD, T. The temporality of the landscape. In: T. INGOLD. The perception of the environment. Essays in livelihood, dwelling and skill. London/New York: Routledge. 2000 .

Trazendo as coisas de volta à vida: emaranhados criativos num mundo de materiais. Horizontes antropológicos, v. 18, n. 37, p. 25-44, 2012.

INPE. Disponível em: http://www.ccst.inpe.br/. Acesso em: 19 de Abril de 2016.

INSTITUTO DE PESQUISAS TECNOLÓGICAS DO ESTADO DE SÃO PAULO (IPT) - Mapa Geomorfológico do Estado de São Paulo, São Paulo, 1981. 
INSTITUTO DE PESQUISAS METEOROLÓGICA DE BAURU (IPMET/UNESP). Disponível em: http://www.ipmet.unesp.br/. Acesso em: 23 de Novembro de 2016.

JARDIM, R.J.G. Creação da Diretoria dos Índios na Província de Mato Grosso (officio dirigido ao Governo Imperial pelo presidente da sobredita Província o Exmo. Sr. coronel Ricardo José Gomes Jardim). Revista do Instituto Histórico Geográfico Brasileiro. Rio de Janeiro, vol. 9, p. 548-554, 1869.

JERNIGAN, E. W. A non-hierarchical approach to ceramic decoration analysis: a Southwestern example. American Antiquity, p. 3-20, 1986.

JONES, S. Archaeology of ethnicity. Taylor \& Francis, 1997.

JOYCE, R.; POLLARD, J. Archaeological assemblages and practices of deposition. In, Hicks, Dan and Beaudry, Mary C. (eds.) The Oxford Handbook of Material Culture. Oxford, GB, Oxford University Press, 291-309. 2010.

JULIANI, L.J.C.O. Programa de Prospecção Arqueológica Intensiva da Quadra 049 - Setor 8 - Campos Elíseos, São Paulo/SP. São Paulo (impresso), 2013.

KASHIMOTO, E. M. Variáveis ambientais e arqueologia no alto do Paraná. 1997. Tese de Doutorado. Faculdade de Filosofia, Letras e Ciências Humanas da Universidade de São Paulo.

KNAPP, A. B.; ASHMORE, W. Archaeological landscapes: constructed, conceptualized, ideational. In: W. ASHMORE e A.B. KNAPP (Eds.). Archaeologies of landscapes: contemporary perspectives. Oxford: Blackwell Publishing. Pp.1-30. 1999.

KOJAN, D. Paths of power and politics: historical narratives at the Bolivian site of Tiwanaku. In: Evaluating Multiple Narratives. Springer New York, 2008. p. 69-85.

LANE, P. Present to Past. Ethnoarchaeology. In: C. TILLEY; W. KEANE; S.KÜCHLER; M. ROWLANDS e P. SPYER (Eds.). Handbook of Material Culture. London: SAGE Publications INC. Pp. 402-424. 2006.

. The use of ethnography in landscape archaeology. In: B. DAVID e J. THOMAS (Eds.). Handbook of Landscape Archaeology. Walnut Creek: LEFT COAST PRESS. Pp. 237-244. 2008.

LANNA, M. Nota Sobre Marcel Mauss e o Ensaio Sobre a Dádiva. Revista de Sociologia e Política, No 14: 173-194 JUN. 2000.

LEMONNIER, P. The study of material culture today: Toward an anthropology of technical systems. Journal of Anthropological Archaeology 5: 147-186. 1986.

L'Étude des systèmes techniques. Une urgence en technologie culturelle. Techniques \& Culture. Revue semestrielle d'anthropologie des techniques, n. 54-55, p. 46-67, 2010.

LEPSCH, I. F. Formação e conservação dos solos. São Paulo: Oficina de Textos, 2007. 
LEROI- GOURHAN, A. O gesto e a palavra: técnica e linguagem. Rio de Janeiro: Edições, v. 70, 1987.

LEWARCH, D. E.; O'BRIEN, M. J. The expanding role of surface assemblages in archaeological research. Advances in archaeological method and theory, p. 297-342, 1981.

LIMA, T. A. Os ceramistas tupiguarani vol. II. Instituto do Patrimônio Histórico e Artístico Nacional, 2010.

O problema da atribuição de identidades étnicas a registros arqueológicos.

Arqueología Tupiguaraní, p. 7-22, 2011.

MAGALHÃES, S. D.; et. al. Análise atômica de pigmentos em cerâmicas Tupinambá. In: LIMA, T. A.; PROUS, A. Os ceramistas tupiguarani: elementos decorativos. Instituto do Patrimônio Histórico e Artístico Nacional, 2010.

MALDONADO, R. Catálogo Bentes - Moedas Brasileiras, 1a edição, 2013. http://www.moedasdobrasil.com.br/catalogo.asp?s=140\&xm=829. Acesso em 18/02/2015 ás 14:00.

MANO, M. Povos Indígenas no Interior Paulista: uma leitura antropológica dos documentos históricos. In: ZANETTINI, P. E.; MORAES, C. A. Programa de Resgate e Monitoramento Arqueológico na Área da Usina Guarani SA Açúcar e Álcool (Usina Cruz Alta - Unidade III). Relatório Final. 2008.

Metáforas Históricas e Realidades Etnográficas: A construção de uma história do contato Kayapó no Triângulo Mineiro. Cadernos de Pesquisa do CDHIS, v. 23, n. 2, 2010.

MANUAL DE OCUPAÇÃO, Capítulo 11 Obras com Estrutura de Contenção, Região Metropolitana do Recife, 2015, disponível em: < http://www2.condepefidem.pe.gov.br>, acesso em: 20 de fev. 2015.

MARANCA, S.; DA SILVA, A.L.M.; SCABELLO, A.M.P. Projeto Oeste Paulista de Arqueologia do Baixo e Médio Vale do rio Tietê: síntese dos trabalhos realizados. Revista do Museu de Arqueologia e Etnologia, n. 4, p. 223-226, 1994.

MARCUS, J.; FLANNERY, K. V. Zapotec civilization: How urban society evolved in Mexico's Oaxaca Valley. Thames and Hudson, 1996.

MAUSS, M. Essai sur le don (1924). Paris: PUF, 2007.

Ensaio sobre a dádiva. Forma e razão da troca nas sociedades arcaicas.

2012.

MELATTI, D. M. Aspectos da organização social dos Kaingáng paulistas. Departamento Geral de Planejamento Comunitário, Divisão de Estudos e Pesquisas, Fundação Nacional do Índio, 1976. 
MEMORIAL

DE

RIOLÂNDIA.

Disponível

em:

http://www.memorialdosmunicipios.com.br/listaprod/memorial/riolandia-

categoria,192,M.html. Acesso em: 24 Novembro de 2017.

MENESES, U. B. O Campo do Patrimônio Cultural: uma revisão de premissas. I Fórum Nacional do Patrimônio Cultural, v.1, 2010.

O campo do Patrimônio Cultural: uma revisão de premissas. IPHAN.

I Fórum Nacional do Patrimônio Cultural: Sistema Nacional de Patrimônio Cultural: desafios, estratégias e experiências para uma nova gestão, Ouro Preto/MG, p. 25-39, 2009.

MIGUEL, R. Estudos de processos erosivos-acumulativos em ocorrências arqueológicas impactadas por reservatório: UHE Capivari-Cachoeira. 2001. Faculdade de Filosofia, Letras e Ciências Humanas da Universidade de São Paulo.

MILLER JR., T.O. Arqueologia da região central do Estado de São Paulo. Dédalo, 16: 13-118. 1972.

MONTEIRO, C. São Vicente do Talhadão. Jornal a Tribuna, Nova Granada, 28 de Agosto de 1988.

MOI, F. P. Os Xerente: um enfoque etnoarqueológico. São Paulo: Annablume, 2007.

MONBEIG, P. Pioneiros e fazendeiros de São Paulo. In: Pioneiros e fazendeiros de São Paulo. Hucitec, 1984.

MORAES, C. A. Arqueologia Tupi no Nordeste de São Paulo: um estudo de variabilidade artefatual. Dissertação (Mestrado), São Paulo, Universidade de São Paulo, 2008.

MORAIS, J.L. Salvamento arqueológico na área de influência da PCH MojiGuaçu. Revista do Museu de Arqueologia e Etnologia, n. 5, p. 77-98, 1995.

Perspectivas Geoambientais da Arqueologia do Paranapanema

Paulista. Tese (Livre-Docência). São Paulo, Universidade de São Paulo, 1999.

Arqueologia da Região Sudeste. Revista USP, Antes de Cabral: arqueologia brasileira II, dez/jan/fev 1999-2000, São Paulo, n44, p.194-217.

Reflexões acerca da Arqueologia Preventiva. In: MORI, Victor Hugo; SOUZA, Marise Campos de; BASTOS, Rossano Lopes; GALLO, Haroldo. (Org.). Patrimônio: Atualizando o Debate. São Paulo: CONAP, 2006, v. 1, p. 191-220.

[primeira versão, excerto]

Curso de Arqueologia Preventiva. São Paulo: ArqGeotec, no prelo 
MORALES, W. F. Um estudo de Arqueologia regional no médio curso do rio Tocantins, Planalto Central brasileira. Revista do Museu de Arqueologia e Etnologia, São Paulo, n. 17, 2007.

MORIN, E.; O MÉTODO I: a natureza da natureza. Porto Alegre: Sulina, 2005a.[Links], 1977.

NASCIMENTO et. al. Comunidade de Palmeiras no território indígena Krahò, Tocantins, Brasil: biodiversidade e aspectos etnobotânicos. Interciência. Vol. 34. No 3. 2009.

NIMUENDAJÚ, C. Os Gorotire. Revista do Museu Paulista, p. 427-53, 1952.

Mapa etnohistórico - Fundação Instituto Brasileiro de Geografia e Estatística em colaboração com a Fundação Nacional Pró-Memória. Rio de Janeiro: IBGE, 1987.

NERY, S.I.; FACCIO, N. B. Variabilidade Lítica dos Sítios Arqueológicos Turvo no Contexto da Tradição Aratu. Revista Tópos, v. 4, n. 1, p. 60-93, 2010.

NERY, J. T.; SILVA, E. S.; CARFAN, A. C. Distribuição da precipitação pluvial no Estado de São Paulo. VI Simpósio Brasileiro de Climatologia Geográfica, v. 6, 2004.

NOELLI, F. As hipóteses sobre os centros de origem e as rotas de expansão dos tupi. Revista de Antropologia, 1996, 39:7-53.

A Ocupação Humana na Região Sul do Brasil: arqueologia, debates e perspectivas 1872-2000. Revista USP, São Paulo, 1999-2000, 44:218-269.

OLIVEIRA, M. Os Cayapós. Revista do Instituto Histórico Geográfico Brasileiro. Rio de Janeiro, vol. 24, p. 491-525, 1861.

OLIVEIRA, F. H.; FACCIO, N. B., LUZ, J. A. R. Análise e interpretação de materiais cerâmicos do Sítio Arqueológico Rosário, Guaíra-SP. Colloquium Humanarum. Vol. 10. No. 1. 2013.

OLIVER, J. Landscapes and social transformations on the Northwest Coast: Colonial Encounters in the Fraser Valley. University of Arizona Press, 2010.

OREJAS, A. El estúdio del Paisaje: visiones desde la Arqueologia. In F. Burillo (ed.) Arqueologia del paisajee. Comunicaciones presentadas al 5 Coloquio Internacional de Arqueologia Espacial (Teruel, 14-16 de septiembre de 1998). Arqueologia Espacial, 19-20: 9-19. Teruel: Seminario de Arqueologia y Etnologia Turolense (Universidad de Zaragoza).

PALLESTRINI, L. Interpretação das Estruturas Arqueológicas em Sítios do Estado de São Paulo. Coleção Museu Paulista, São Paulo, Vol.1, 1975.

PARDI, M. L. F.; IQUEGAMI, A. E. F. Preservação do Patrimônio e Levantamento Arqueológico da Região de Ouroeste - SP. 9a SR/IPHAN/SP - Secretaria de Educação e Cultura da Prefeitura de Ouroeste, 1999 
PARSONS, Jeffrey R. "Archaeological settlement patterns." Annual Review of Anthropology 1 (1972): 127-150.

PATTERSON, T. A brief history of landscape archaeology in the Americas. Handbook of Landscape Archaeology, Left Coast Press, Walnut Creek, CA, 2008.

PEARSON, M. P.; RICHARDS, C. (Ed.). Architecture and order: approaches to social space. Routledge, 2003.

PEREIRA, D.L.T. Arqueologia guarani na bacia do rio Santo Anastácio-SP: estudo do sítio Célia Maria. 2011. Dissertação de Mestrado. Universidade de São Paulo.

POHL, J. E. Viagem no Interior do Brasil. Primeira Parte. Rio de Janeiro. Instituto Nacional do Livro, 1951.

PONÇANO, W. L. Mapa geomorfológico do estado de São Paulo. Instituto de Pesquisas Tecnológicas do Estado de São Paulo, Divisão de Minas e Geologia Aplicada, 1981.

POSEY, D. A. Kayapó mostra aldeia de origem. Revista da Atualidade Indígena, v. 3, n. 15 , p. 50-7, 1979.

PROUS, A. Arqueologia brasileira. Editora UnB, 1991.

RASTEIRO, Renan Pezzi. Arqueologia dos Jê da Bacia do Rio Grande: história indígena no Norte de São Paulo e no Triângulo Mineiro. Dissertação de Mestrado. Universidade de São Paulo, 2015.

Arqueologia Jê no sertão paulista: os Kayapó Meridionais na bacia do Rio Grande-SP. Revista do Museu de Arqueologia e Etnologia, n. 27, p. 90-102, 2017.

REDMAN, C.L; WATSON, P. Systematic, Intensive Surface Collection. American Antiquity, Vol.35, No. 3 (Jul. 1970), p. 279-291. Published by Society for American Archaeology URL: http://www.jstor.org/stable/278339, Accessed 27/07/2010, 08:23.

RENFREW, C.; BAHN, P. Whose Past? Archaeology and the Public. Archaeology: Theories, Methods and Practice, ed. C. Renfrew and P. Bahn, p. 545-574, 2008.

ROBRAHN-GONZÁLEZ, E. M. Os grupos ceramistas pré-coloniais do Centro-Oeste brasileiro. Revista do Museu de Arqueologia e Etnologia, v. 6, n. 1996, p. 83-122, 1996.

São Paulo, terra de fronteiras: a ocupação de grupos ceramistas pré-coloniais. São Paulo: MAE, 2000.

ROBRAHn-GONZÁleZ, E. M. et al., Água Vermelha, Pesquisa Arqueológica de Salvamento. Relatório CESP. MAE / USP. 1998. 
ROBRAHN-GONZÁLEZ, E. M.; DE BLASIS, P. Programa de Manejo Arqueológico Aproveitamentos Hidrelétricos da AES TIETÊ S A, São Paulo - Minas Gerais. Relatório de andamento 5 UHE Água Vermelha. 2010

RODRIGUES, A.D. Línguas brasileiras: para o conhecimento das línguas indígenas. Edições Loyola, 1994.

RODRIGUES. I. M. R.; Fora das grandes aldeias: a ocupação do recôndito sítio arqueológico Vereda III. 2011. Dissertação de Mestrado. Universidade Federal de Minas Gerais.

RODRIGUES, R. Programa de Prospecções Arqueológicas. Área de Ampliação do Plantio de Cana-de-açúcar do Empreendimento Usina Bela Vista, Região de Pontal, Estado de São Paulo, 2008.

RUBIN, J. C. R; SILVA, R. T. Arqueologia, Dinâmica das Vertentes e Perda de Solos. Revista do Museu de Arqueologia e Etnologia, São Paulo, 14, 2004, p. 179-193.

SAHLINS, M. Sociedades Tribais. Rio de Janeiro: Zahar, p. 47-76, 1970.

SANT'ANNA NETO, João L. Clima e organização do espaço. Boletim de Geografia, v. 16, n. 1, p. 119-131, 1998.

SAINT-HILAIRE, A. Viagem às nascentes do Rio S. Francisco e pela Província de Goyaz. Tomo segundo. São Paulo, Companhia Editora Nacional, 1937.

SAUER, C. O. A morfologia da paisagem. In: CORREA, R.L.; ROSENDAHL, Z. (orgs.) Paisagem, tempo e cultura. Rio de Janeiro: EdUERJ, 2004, p. 12-74.

. La morfología del Paisaje. Polis. Revista Latinoamericana, n. 15, 2006.

SCATAMACCHIA, M. C. M. Considerações sobre a distribuição das sociedades tribais de filiação linguística Tupi-guarani no Estado de São Paulo. In: PROUS, A.; LIMA, T. A. (Org.). Os ceramistas tupiguarani. Belo Horizonte: Sigma, 2006, v. 1, p. 117-144.

A recuperação da capela de Nossa Senhora da Escada: arqueologia urbana em Barueri. Revista do Museu de Arqueologia e Etnologia, n. 13, p. 331-335, 2016.

SCHADEN, E. Os primitivos habitantes do território paulista. Revista de História, v. 8, n. 18, p. 385-406, 1954.

SCHIFFER, M. B. Archaeology as behavioral science. American Anthropologist, v. 77, n. 4, p. 836-848, 1975.

SCHIFFER, M. B. et al. Behavioral archaeology: Principles and practice. Equinox, 2010.

SCHIFFER, M. B.; SKIBO, J. M. The explanation of artifact variability. American Antiquity, p. 27-50, 1997. 
SCHMITZ, P. I. Arqueologia de Goiás: Sequência cultural e datações de C14. Anuário de Divulgação Cientifica, p. 3-4, 1976.

SCHMITZ, P. I. et al. Arqueologia do Centro-Sul de Goiás. Uma fronteira de horticultores indígenas no Centro do Brasil. Pesquisas. Antropologia, n. 33, p. 1-281, 1982.

SCHMITZ, P. I.; ROGGE, J. H. Um sítio da tradição cerâmica Aratu em Apucarana, PR. Revista do Museu de Arqueologia e Etnologia, n. 18, p. 47-68, 2008.

SKIBO, J. M.; SCHIFFER, M. B. People and things: A behavioral approach to material culture. Springer Science \& Business Media, 2008.

SETTON, M. G. J. A teoria do habitus em Pierre Bourdieu: uma leitura contemporânea. Revista Brasileira de Educação, nº 20, Maio/Jun/Jul/Ago 2002

SHANKS, M.; TILLEY, C. Y. Re-constructing archaeology: theory and practice. Psychology Press, 1992.

SNEAD, James E. Trails of tradition: Movement, meaning, and place. Landscapes of Movement: Trails, Paths, and Roads in Anthropological Perspective, Museum of Archaeology and Anthropology, University of Pennsylvania, Philadelphia, p. 42-60, 2009.

STALLER, John. Pre-Columbian landscapes of creation and origin. Springer, 2008.

STEIN, Gil (Ed.). The archaeology of colonial encounters: comparative perspectives. School of American Research Press, 2005.

STRANGHETTI, V.; RANGA, N. T. Levantamento florístico das espécies vasculares da floresta estacional mesófila semidecídua da Estação Ecológica de Paulo de Faria - SP. Brazilian Journal of Botany, v. 21, n. 3, 1998.

SUGUIO, K. Dicionário de geologia sedimentar e áreas afins. Brasil, 1998.

TAUNAY, A. História das bandeiras paulistas. CDPB, 2012.

TILLEY, Christopher Y. A phenomenology of landscape: places, paths, and monuments. Oxford: Berg, 1994.

THOMAZ, R. C. C. O uso de Sig na predição da localização de sítios arqueológicos: um estudo de caso na bacia do Paraná Superior. Tese (Doutorado em Arqueologia). Museu de Arqueologia e Etnologia, Universidade de São Paulo, 2002.

THOMAS, J. The trouble with material culture. Journal of iberian archaeology, n. 9, p. 11-24, 2007.

TRIGGER, B. G. Settlement Archaeology. Its Goals and Promise. American Antiquity, p. 149-160, 1967. 
Historia del pensamiento arqueológico. Barcelona: Crítica, D. L.

1992

TURNER, T. From cosmology to ideology: resistance, adaptation and social consciousness among the Kayapo. University of Chicago, 1987.

VASCONCELOS, E. A. Proposta de sistema fonológico para a língua dos Cayapó do Sul aldeados em São José de Mossâmedes. ESTUDOS LINGUÍSTICOS, v. 42, n. 1, p. 257 $269,2013$.

VIDAL, L.; SILVA, A. L. O sistema de objetos nas sociedades indígenas: arte e cultura material. SILVA, Al; GRUPIONI, LDB A temática indígena na escola: novos subsídios para professores de 10 e 20 graus. Brasília, MEC/MARE/UNESCO, 1995.

VITTE, A. C. O desenvolvimento do conceito de paisagem e a sua inserção na geografia física. Mercator-Revista de Geografia da UFC, v. 6, n. 11, p. 71-78, 2007.

VIVEIROS DE CASTRO, E. A inconstância da alma selvagem. São Paulo: Cosac \& Naify, 2002.

WALKER, W. H. The Materiality of Social Power in SCHIFFER, Michael B. et al. Behavioral archaeology: Principles and practice. Equinox, 2010.

WHITELAW, T. M. Order without architecture: functional, social and symbolic dimensions in hunter-gatherer settlement organization. Architecture and Order: approaches to social space, p. 217-43, 1994.

WHITRIDGE, P. Landscapes, houses, bodies, things: place and the archaeology of Inuit imaginaries. Journal of Archaeological Method and Theory, 11(2):213-250. 2004.

WILLEY, G. R. Prehistoric settlement patterns in the Viru Valley, Peru. Bulletin ,1. Washington, DC: Bureau of American Ethnology. 1953.

WOBST, H. Martin. Indigenous archaeologies: a worldwide perspective on human materialities and human rights. Indigenous Archaeologies: A Reader on Decolonization, p. 17-27, 2010.

WUST, I. Aspectos da Ocupação Pré-Colonial em uma Área do Mato Grosso de Goiás: tentativa de análise espacial. Dissertação de Doutorado. Faculdade de Filosofia, Letras e Ciências Humanas da Universidade de São Paulo, São Paulo, 1983.

Continuidade e Mudança - Para uma interpretação dos grupos ceramistas pré - coloniais da bacia do Rio Vermelho, Mato Grosso. Tese (Doutorado em Antropologia). Faculdade de Filosofia, Letras e Ciências Humanas da Universidade de São Paulo, São Paulo, 1990.

Padrões de Assentamento de Grupos Agricultores Pré-Coloniais em Uma Área do Mato Grosso de Goiás. Anais I Simpósio Pré-História - CLIO, 4. 1991. 
ZANETTINI, P. E.; MORAES, C. A. Programa de Resgate e Monitoramento Arqueológico na Área da Usina Guarani SA Açúcar e Álcool (Usina Cruz Alta - Unidade III). Relatório Final. 2008.

ZANETTINI, P. E.; MORAES, C. A. Programa de Resgate Área de expansão de cultivo da Usina São José, Estado de São Paulo. Relatório final 1. 2009.

ZEDEÑO, M.I. Landscapes, land use, and the history of territory formation: an example from puebloan southwest. Journal of Archaeological Method and Theory, 4(1):63-103. 1997.

ZEDEÑO, M. N.; BOWSER, B. J. The archaeology of meaningful places. In: B.J. BOWSER; M.N. ZEDEÑO (Eds.). The archaeology of meaningful places. Salt Lake City: The University of Utah Press. Pp. 1-14. 2009.

ZEDEÑO, M.N.; HOLLENBACK, K.; GRINNELL, C. From path to myth: journeys and the naturalization of territorial identity along the Missouri river. In: J.E. SNEAD; C.L. 2009. 
ANEXOS 
ANEXO 1- Sítios Arqueológicos localizados no CAR.

\begin{tabular}{|c|c|c|c|c|c|c|}
\hline & $\begin{array}{c}\text { SÍTIO/ } \\
\text { AUTOR/ ANO }\end{array}$ & $\begin{array}{l}\text { CORPO DE ÁGUA } \\
\text { PRÓXIMO/BACIA } \\
\text { HIDROGRÁFICA }\end{array}$ & CARACTERÍSTICAS GERAIS & $\begin{array}{l}\text { LOCALIZAÇÃO } \\
\text { (UTM) }\end{array}$ & $\begin{array}{l}\text { Idade (anos } \\
\text { antes do } \\
\text { presente) }\end{array}$ & $\begin{array}{c}\text { TÉCNICA/LABOR } \\
\text { ATÓRIO }\end{array}$ \\
\hline 1 & $\begin{array}{l}\text { Ararinha / } \\
\text { FACCIO (2011) }\end{array}$ & $\begin{array}{l}\text { São José dos } \\
\text { Dourados }\end{array}$ & $\begin{array}{l}\text { Classificação: Tupiguarani } \\
\text { Inserção na paisagem: } \\
\text { Área do sítio: } \\
\text { Quantidade de material: } 314 \\
\text { fragmentos de cerâmica e } 63 \text { peças líticas } \\
\text { lascadas; } \\
\text { Tipo de Material cerâmico: tipo de } \\
\text { antiplástico (80,25\% mineral, } 17,51 \% \\
\text { mineral associado ao caco-moído, } 1,91 \% \\
\text { mineral associado ao cariapé); tratamento } \\
\text { de superfície: (98,42\% liso, } 1,58 \% \\
\text { engobo). }\end{array}$ & $\begin{array}{c}22 \mathrm{k} \\
591071 / 7743763\end{array}$ & $\begin{array}{l}175 \pm 30 \\
\text { A.P. }\end{array}$ & $\begin{array}{l}\text { Técnica de } \\
\text { Termoluminescência } \\
\text { (TL) / } \\
\text { Laboratório de } \\
\text { Datação, Comércios e } \\
\text { Serviços Ltda. }\end{array}$ \\
\hline 2 & $\begin{array}{l}\text { Santa Cruz / } \\
\text { FACCIO (2011) }\end{array}$ & $\begin{array}{l}\text { São José dos } \\
\text { Dourados }\end{array}$ & $\begin{array}{l}\text { Classificação: Tupiguarani/Uru } \\
\text { Tupiguarani (pintado e corrugado) e Uru } \\
\text { (cariapé) } \\
\text { Inserção na paisagem: Localizado a } \\
\text { aproximadamente } 6 \mathrm{~km} \text { do curso do Rio } \\
\text { São José dos Dourados, situado numa } \\
\text { área de cabeceira de drenagem; } \\
\text { Área do sítio: Área aproximada de } 20 \\
\text { x } 20 \text { metros; } \\
\text { Quantidade de material: } \\
\text { fragmentos de cerâmica; } \\
\text { Tipo de Material cerâmico: tipo de } \\
\text { antiplástico (84,61\% mineral, } 14,40 \% \\
\text { mineral associado ao cariapé, 0,48\% } \\
\text { mineral associado ao caco-moído); } \\
\text { tratamento de superfície: (98,55\% liso, } \\
0,96 \% \text { pintado, 0,48\% decoração } \\
\text { plástica). }\end{array}$ & $\begin{array}{c}22 \mathrm{k} \\
587006 / 7740463\end{array}$ & $\begin{array}{l}205 \pm 25 \\
\text { A.P. }\end{array}$ & $\begin{array}{l}\text { Técnica de } \\
\text { Termoluminescência } \\
\text { (TL) / } \\
\text { Laboratório de } \\
\text { Datação, Comércios e } \\
\text { Serviços Ltda. }\end{array}$ \\
\hline
\end{tabular}




\begin{tabular}{|c|c|c|c|c|c|c|}
\hline 3 & $\begin{array}{l}\text { Água Branca / } \\
\text { AFONSO E } \\
\text { MORAES, } 2007\end{array}$ & $\begin{array}{c}\text { Bacia do } \\
\text { Pardo/Grande }\end{array}$ & $\begin{array}{l}\text { Classificação: Aratu / Tupiguarani/ Uru; } \\
\text { Inserção na paisagem: Localiza-se à } \\
\text { margem direita do córrego Água Branca, } \\
\text { ocupando as partes baixa e média de uma } \\
\text { vertente de inclinação suave; } \\
\text { Área do sítio: Área aproximada de } 200 \text { x } \\
140 \text { metros (área elíptica da concentração } \\
\text { de material arqueológico); } \\
\text { Quantidade de material: } \\
\text { fragmentos de cerâmica; } \\
\text { Tipo de Material cerâmico: tipo de } \\
\text { antiplástico ( } 85,90 \% \text { mineral, } 13,42 \% \\
\text { mineral associado ao caco-moído, } 0,67 \% \\
\text { mineral associado ao cariapé); tratamento } \\
\text { de superfície: (Não informado). }\end{array}$ & $\begin{array}{c}22 \mathrm{k} \\
286551 / 7602286\end{array}$ & $\begin{array}{c}205 \pm 20 \\
\text { A.P. }\end{array}$ & \\
\hline 4 & $\begin{array}{l}\text { Viradouro / } \\
\text { FACCIO (2011) }\end{array}$ & $\begin{array}{c}\text { São José dos } \\
\text { Dourados }\end{array}$ & $\begin{array}{l}\text { Classificação: Tupiguarani; } \\
\text { Inserção na paisagem: Localizado } \\
\text { próximo a área da foz do Córrego } \\
\text { Viradouro com o Rio São José dos } \\
\text { Dourados; } \\
\text { Área do sítio: Área aproximada de } 40 \text { x } \\
60 \text { metros; } \\
\text { Quantidade de material: } 447 \\
\text { fragmentos cerâmicos e } 26 \text { peças líticas } \\
\text { lascadas. } \\
\text { Tipo de Material cerâmico: tipo de } \\
\text { antiplástico ( } 48,09 \% \text { mineral, } 38,19 \% \\
\text { cariapé, 13,56\% caco-moído e } 0,16 \% \\
\text { caco-moído associado ao cariapé); } \\
\text { tratamento de superfície: (94,85\% liso, } \\
4,01 \% \text { decoração plástica, } 0,88 \% \\
\text { engobo). }\end{array}$ & $\begin{array}{c}22 \mathrm{k} \\
588117 / 7732705\end{array}$ & $\begin{array}{c}265 \pm 45 \\
\text { A.P. }\end{array}$ & $\begin{array}{l}\text { Técnica de } \\
\text { Termoluminescência } \\
\text { (TL) / } \\
\text { Laboratório de } \\
\text { Datação, Comércios e } \\
\text { Serviços Ltda. }\end{array}$ \\
\hline
\end{tabular}




\begin{tabular}{|c|c|c|c|c|c|c|}
\hline 5 & $\begin{array}{l}\text { Abelha / } \\
\text { FACCIO (2011) }\end{array}$ & $\begin{array}{l}\text { São José dos } \\
\text { Dourados }\end{array}$ & $\begin{array}{l}\text { Classificação: Tupiguarani; } \\
\text { Inserção na paisagem: Localizado a } \\
\text { aproximadamente } 530 \text { metros do Rio São } \\
\text { José dos Dourados e aproximadamente } \\
\text { noventa metros da margem direita de um } \\
\text { pequeno córrego tributário desse rio; } \\
\text { Área do sítio: Área quadrilátera de } 100 \text { x } \\
40 \text { metros; } \\
\text { Quantidade de material: } 87 \text { peças } \\
\text { líticas lascadas, } 06 \text { peças polidas ( } 01 \\
\text { tembetá) e } 901 \text { fragmentos de cerâmica; } \\
\text { Tipo de Material cerâmico: tipo de } \\
\text { antiplástico ( } 65,37 \% \text { mineral, } 20,31 \% \\
\text { mineral associado ao caco moído, } 5,66 \% \\
\text { mineral associado ao cariapé); tratamento } \\
\text { de superfície: ( } 94,56 \% \text { liso, } 2,66 \% \\
\text { engobo, 1,44\% decoração plástica e } \\
1,00 \% \text { pintado) }\end{array}$ & $\begin{array}{c}22 \mathrm{k} \\
581717 / 7731527\end{array}$ & $\begin{array}{l}290 \pm 25 \\
\text { A.P. }\end{array}$ & $\begin{array}{l}\text { Técnica de } \\
\text { Termoluminescência } \\
\text { (TL) / } \\
\text { Laboratório de } \\
\text { Datação, Comércios e } \\
\text { Serviços Ltda. }\end{array}$ \\
\hline 6 & $\begin{array}{l}\text { Rosário / } \\
\text { FACCIO (2012a) }\end{array}$ & Baixo Pardo/Grande & $\begin{array}{l}\text { Classificação: Aratu-Sapucaí; } \\
\text { Inserção na paisagem: Localiza-se na } \\
\text { baixa vertente de uma colina aplainada, } \\
\text { de suave inclinação. Sua cota altimétrica } \\
\text { é de aproximadamente } 510 \text { metros em } \\
\text { relação ao nível do mar. Encontra-se } \\
\text { próximo ao Ribeirão do Rosário; } \\
\text { Área do sítio: Área aproximada de } 650 \text { x } \\
300 \text { metros; } \\
\text { Quantidade de material: } \\
\text { fragmentos de cerâmica; } \\
\text { Tipo de Material cerâmico: tipo de } \\
\text { antiplástico (Não informado); tratamento } \\
\text { de superfície: (100,00\% liso) }\end{array}$ & $\begin{array}{c}22 \mathrm{k} \\
785695 / 7734876\end{array}$ & $\begin{array}{l}300 \pm 40 \\
\text { A.P. }\end{array}$ & $\begin{array}{l}\text { Técnica de } \\
\text { Termoluminescência } \\
\text { (TL) / } \\
\text { Laboratório de } \\
\text { Datação, Comércios e } \\
\text { Serviços Ltda. }\end{array}$ \\
\hline 7 & $\begin{array}{l}\text { Lajeado / } \\
\text { FACCIO (2011) }\end{array}$ & $\begin{array}{l}\text { São José dos } \\
\text { Dourados }\end{array}$ & $\begin{array}{l}\text { Classificação: Tupiguarani } \\
\text { Indicativos de cerâmica Tupiguarani }\end{array}$ & $\begin{array}{c}22 \mathrm{k} \\
583016 / 7724327\end{array}$ & $\begin{array}{l}315 \pm 45 \\
\text { A.P. }\end{array}$ & $\begin{array}{l}\text { Técnica de } \\
\text { Termoluminescência } \\
\text { (TL) / }\end{array}$ \\
\hline
\end{tabular}




\begin{tabular}{|c|c|c|c|c|c|c|}
\hline & & & $\begin{array}{l}\text { Inserção na paisagem: Localizado a } 350 \\
\text { metros do Rio São José dos Dourados, } \\
\text { próximo dos Sítios Abelha e Dourados; } \\
\text { Área do sítio: Área aproximada de } 100 \text { x } \\
40 \text { metros; } \\
\text { Quantidade de material: } 97 \text { fragmentos } \\
\text { de cerâmica, } 28 \text { peças líticas lascadas e } \\
01 \text { peça lítica polida; } \\
\text { Tipo de Material cerâmico: tipo de } \\
\text { antiplástico ( } 72,69 \% \text { mineral, } 15,86 \% \\
\text { mineral associado ao cariapé, } 10,70 \% \\
\text { mineral associado ao caco moído); } \\
\text { tratamento de superfície: (92,78\% liso, } \\
3,09 \% \text { decoração plástica e } 2,06 \% \\
\text { pintura) }\end{array}$ & & & $\begin{array}{l}\text { Laboratório de } \\
\text { Datação, Comércios e } \\
\text { Serviços Ltda. }\end{array}$ \\
\hline 8 & $\begin{array}{l}\text { Olímpia IV / } \\
\text { ZANETTINI; } \\
\text { MORAES } \\
\text { MORAES } \\
(2008)\end{array}$ & Turvo/Grande & $\begin{array}{l}\text { Classificação: Tupiguarani } \\
\text { Inserção na paisagem: Situa-se a } 140 \\
\text { metros do córrego do Paiolinho, em } \\
\text { localização estratégica, numa área onde } \\
\text { se dá o encaixe de duas drenagens no } \\
\text { córrego do Paiolinho, este com volume } \\
\text { de água significativo até os dias atuais; } \\
\text { Área do sítio: Área aproximada de } 250 \text { x } \\
150 \text { metros; } \\
\text { Quantidade de material: } \\
\text { Aproximadamente } 1250 \text { fragmentos de } \\
\text { cerâmica, } 142 \text { peças líticas lascadas e } 24 \\
\text { peças líticas polidas; } \\
\text { Tipo de Material cerâmico: Sem } \\
\text { informação. }\end{array}$ & $\begin{array}{c}22 \mathrm{k} \\
0700533 / 7717054\end{array}$ & $\begin{array}{l}340 \pm 80 \\
\text { A.P. }\end{array}$ & $\begin{array}{l}\text { Técnica de } \\
\text { Termoluminescência } \\
(\mathrm{TL}) /\end{array}$ \\
\hline 9 & $\begin{array}{l}\text { Olímpia VII / } \\
\text { ZANETTINI; } \\
\text { MORAES } \\
(2008)\end{array}$ & Turvo/Grande & $\begin{array}{l}\text { Classificação: Aratu/Uru } \\
\text { Inserção na paisagem: Implantado em } \\
\text { meia encosta, localizada na nascente de } \\
\text { córrego sem nome (tributário do Córrego }\end{array}$ & $\begin{array}{c}22 \mathrm{k} \\
0700871 / 7715882\end{array}$ & $\begin{array}{l}360 \pm 80 \\
\text { A.P. } \\
490 \pm 110 \\
\text { A.P. }\end{array}$ & $\begin{array}{l}\text { Técnica de } \\
\text { Termoluminescência } \\
(\mathrm{TL}) /\end{array}$ \\
\hline
\end{tabular}




\begin{tabular}{|c|c|c|c|c|c|c|}
\hline & & & $\begin{array}{l}\text { do Paiolinho). O material arqueológico } \\
\text { foi encontrado em concentrações } \\
\text { paralelas à drenagem em locais ocupados } \\
\text { atualmente por pasto/plantação de milho } \\
\text { e por plantio de cana-de-açúcar; } \\
\text { Área do sítio: Área aproximada de } 250 \text { x } \\
100 \text { metros; } \\
\text { Quantidade de material: } \\
\text { Aproximadamente } 1600 \text { fragmentos de } \\
\text { cerâmica, } 20 \text { peças líticas lascadas e } 02 \\
\text { peças líticas polidas; } \\
\text { Tipo de Material cerâmico: Sem } \\
\text { informação. }\end{array}$ & & & \\
\hline 10 & $\begin{array}{l}\text { Turvo Va / } \\
\text { FACCIO (2014) }\end{array}$ & Turvo/Grande & $\begin{array}{l}\text { Classificação: Aratu Sapucaí } \\
\text { Inserção na paisagem: Localiza-se na } \\
\text { margem direita do Córrego do Anil, } \\
\text { distante cerca de } 800 \text { metros do seu } \\
\text { encontro com o Rio Turvo. O sítio está } \\
\text { numa colina ampla de vertente levemente } \\
\text { acentuada e topo aplainado e fica } \\
\text { localizado na baixa vertente. } \\
\text { Área do sítio: } \\
\text { Quantidade de material: } 311 \text { peças } \\
\text { líticas lascadas, } 04 \text { peças líticas polidas e } \\
820 \text { fragmentos de cerâmica. } \\
\text { Tipo de Material cerâmico: tipo de } \\
\text { antiplástico (100,00\% } \\
\text { tratamento de superfície: }(98,17 \% \text { liso, } \\
\text { 1,59\% decoração plástica, } 0,12 \% \text { engobo, } \\
0,12 \% \text { pintado). }\end{array}$ & $\begin{array}{c}22 \mathrm{k} \\
631905 / 7774404\end{array}$ & $\begin{array}{l}375 \pm 40 \\
\text { A.P. }\end{array}$ & $\begin{array}{l}\text { Técnica de } \\
\text { Termoluminescência } \\
\text { (TL) / } \\
\text { 10Laboratório de } \\
\text { Datação, Comércios e } \\
\text { Serviços Ltda. }\end{array}$ \\
\hline 11 & $\begin{array}{l}\text { Água Limpa / } \\
\text { ALVES (2004); } \\
\text { BELO (2007) }\end{array}$ & Turvo/Grande & $\begin{array}{l}\text { Classificação: Sem classificação } \\
\text { Inserção na paisagem: Situa-se em um } \\
\text { vale, circundado, parcialmente, pela serra } \\
\text { de Jaboticabal, entre dois cursos de água: }\end{array}$ & $\begin{array}{c}22 \mathrm{k} \\
754238 / 7646336\end{array}$ & $\begin{array}{c}375 \pm 40 \\
\text { A.P. } \\
1524 \pm 212 \\
\text { A.P. }\end{array}$ & \\
\hline
\end{tabular}




\begin{tabular}{|c|c|c|c|c|c|c|}
\hline & & & $\begin{array}{l}\text { córregos Água Limpa, ao sul e Santa } \\
\text { Luzia, ao norte; } \\
\text { Área do sítio: } \\
\text { Quantidade de material: } 111 \text { peças } \\
\text { líticas lascadas, } 37 \text { peças líticas polidas e } \\
5.341 \text { fragmentos de cerâmica (referente } \\
\text { a terceira, quarta e quinta campanha de } \\
\text { escavação) } \\
\text { Tipo de Material cerâmico: tipo de } \\
\text { antiplástico (Não informado); tratamento } \\
\text { de superfície: ( } 86,72 \% \text { liso, } 11,43 \% \\
\text { pintado, } 1,85 \% \text { engobo). }\end{array}$ & & & \\
\hline 12 & $\begin{array}{l}\text { Meridiano / } \\
\text { FACCIO (2011) }\end{array}$ & $\begin{array}{l}\text { São José dos } \\
\text { Dourados }\end{array}$ & $\begin{array}{l}\text { Classificação: Tupiguarani } \\
\text { Inserção na paisagem: Encontra-se } \\
\text { próximo a um afluente do Rio São José } \\
\text { dos Dourados; } \\
\text { Área do sítio: Área aproximada de } 120 \text { x } \\
120 \text { metros; } \\
\text { Quantidade de material: } 40 \text { peças } \\
\text { líticas lascadas, } 01 \text { peça lítica polida } \\
\text { (tembetá em quartzo polido) e } 830 \\
\text { fragmentos de cerâmica; } \\
\text { Tipo de Material cerâmico: tipo de } \\
\text { antiplástico (61,60\% mineral, } 21,00 \% \\
\text { mineral associado ao caco moído, } \\
\text { 14,00\% mineral associado ao carvão); } \\
\text { tratamento de superfície: (92,2\% liso, } \\
4,30 \% \text { engobo, } 1,50 \% \text { pintado e } 0,80 \% \\
\text { decoração plástica). }\end{array}$ & $\begin{array}{c}22 \mathrm{k} \\
585503 / 7741480\end{array}$ & $\begin{array}{l}380 \pm 75 \\
\text { A.P. }\end{array}$ & $\begin{array}{l}\text { Técnica de } \\
\text { Termoluminescência } \\
\text { (TL) / } \\
\text { Laboratório de } \\
\text { Datação, Comércios e } \\
\text { Serviços Ltda. }\end{array}$ \\
\hline 13 & $\begin{array}{l}\text { Cervo / FACCIO } \\
(2012 a)\end{array}$ & $\begin{array}{c}\text { Sapucaí } \\
\text { Mirim/Grande }\end{array}$ & $\begin{array}{l}\text { Classificação: Aratu-Sapucaí } \\
\text { Inserção na paisagem: Localiza-se na } \\
\text { baixa vertente de uma colina aplainada } \\
\text { que possui inclinação suave. A altura do }\end{array}$ & $\begin{array}{c}22 \mathrm{k} \\
787958 / 7760849\end{array}$ & $\begin{array}{l}395 \pm 40 \\
\text { A.P. }\end{array}$ & $\begin{array}{l}\text { Técnica de } \\
\text { Termoluminescência } \\
\text { (TL) / }\end{array}$ \\
\hline
\end{tabular}




\begin{tabular}{|c|c|c|c|c|c|c|}
\hline & & & $\begin{array}{l}\text { local é de aproximadamente } 490 \text { metros } \\
\text { em relação ao nível do mar. Os principais } \\
\text { recursos hídricos são o Córrego Corta } \\
\text { Pescoço e também o rio Sapucaí; } \\
\text { Área do sítio: Área aproximada de } 875 \text { x } \\
250 \text { metros; } \\
\text { Quantidade de material: } 50 \text { peças } \\
\text { líticas lascadas e } 231 \text { fragmentos de } \\
\text { cerâmica; } \\
\text { Tipo de Material cerâmico: tipo de } \\
\text { antiplástico (100,00\% mineral); } \\
\text { tratamento de superfície: (100,00\% liso); }\end{array}$ & & & $\begin{array}{l}\text { Laboratório de } \\
\text { Datação, Comércios e } \\
\text { Serviços Ltda. }\end{array}$ \\
\hline 14 & $\begin{array}{l}\text { Santa Filomena } \\
\text { (FACCIO, 2015) }\end{array}$ & Turvo/Grande & $\begin{array}{l}\text { Classificação: Sítio histórico } \\
\text { Inserção na paisagem: Localiza-se em } \\
\text { área de média-alta vertente, próximo ao } \\
\text { córrego do Talhadão e a } 1 \mathrm{~km} \text { do rio } \\
\text { Turvo. } \\
\text { Área do sítio: Possui formato } \\
\text { quadrangular, com cerca de } 575 \mathrm{~m}^{2} \text {. } \\
\text { Quantidade de material: } 01 \mathrm{moeda}^{2} \\
\text { cobre com padrão monetário em Réis, } \\
125 \text { fragmentos de materiais vítreos e } 08 \\
\text { fragmentos de cerâmica contemporânea. }\end{array}$ & $\begin{array}{c}22 \mathrm{k} \\
655944 / 7765188\end{array}$ & & \\
\hline 15 & $\begin{array}{l}\text { Bela Vista do } \\
\text { Jacaré / FACCIO } \\
\text { (2012a) }\end{array}$ & Pardo/Grande & $\begin{array}{l}\text { Classificação: Aratu-Sapucaí } \\
\text { Tupiguarani (paredes carenadas) } \\
\text { Inserção na paisagem: Localiza-se na } \\
\text { média vertente de uma colina aplainada, } \\
\text { em altimetria de } 470 \text { metros, possuindo } \\
\text { uma suave inclinação. Nos arredores do } \\
\text { Sítio Bela Vista do Jacaré está localizado } \\
\text { o Rio Pardo. Além desse corpo hídrico, } \\
\text { existe também nas proximidades o } \\
\text { Córrego do Jacaré; }\end{array}$ & $\begin{array}{c}22 \mathrm{k} \\
763490 / 7744748\end{array}$ & $\begin{array}{l}420 \pm 50 \\
\text { A.P. }\end{array}$ & $\begin{array}{l}\text { Técnica de } \\
\text { Termoluminescência } \\
\text { (TL)/ } \\
\text { Laboratório de } \\
\text { Datação, Comércios e } \\
\text { Serviços Ltda. }\end{array}$ \\
\hline
\end{tabular}




\begin{tabular}{|c|c|c|c|c|c|c|}
\hline & & & $\begin{array}{l}\text { Área do sítio: Área aproximada de } 830 \text { x } \\
220 \text { metros; } \\
\text { Quantidade de material: } 807 \text { peças } \\
\text { líticas lascadas, } 05 \text { peças líticas polidas e } \\
17.249 \text { fragmentos de cerâmica; } \\
\text { Tipo de Material cerâmico: tipo de } \\
\text { antiplástico (Não Informado); tratamento } \\
\text { de superfície: ( } 99,32 \% \text { liso, 0,56\% } \\
\text { plástico [predominantemente inciso], } \\
0,12 \% \text { engobado); }\end{array}$ & & & \\
\hline 16 & $\begin{array}{l}\text { Colina I / } \\
\text { ZANETTINI; } \\
\text { MORAES } \\
(2009)\end{array}$ & Baixo Pardo/Grande & $\begin{array}{l}\text { Classificação: Tupiguarani } \\
\text { Inserção na paisagem: Localiza-se em } \\
\text { meia encosta de colina suave ocupada por } \\
\text { plantio de cana, a } 260 \text { metros da margem } \\
\text { do Córrego do Capim. } \\
\text { Área do sítio: Área aproximada de } 300 \text { x } \\
100 \text { metros; } \\
\text { Quantidade de material: } 09 \text { peças } \\
\text { líticas lascadas e } 1.433 \text { fragmentos de } \\
\text { cerâmica; } \\
\text { Tipo de Material cerâmico: tipo de } \\
\text { antiplástico ( } 79,3 \% \text { mineral associado ao } \\
\text { caco-moído, } 14,9 \% \text { mineral associado a } \\
\text { hematita, } 5,2 \% \text { mineral e } 0,6 \% \text { mineral } \\
\text { associado ao carvão); tratamento de } \\
\text { superfície: ( } 96,00 \% \text { liso, 2,5\% decoração } \\
\text { plástica, } 1,5 \% \text { com engobo). }\end{array}$ & $\begin{array}{c}22 \mathrm{k} \\
0752911 / 7716559\end{array}$ & $\begin{array}{l}420 \pm 40 \\
\text { A.P. }\end{array}$ & $\begin{array}{l}\text { Técnica de } \\
\text { Termoluminescência } \\
\text { (TL) / }\end{array}$ \\
\hline 17 & $\begin{array}{l}\text { Ribeirão das } \\
\text { Pitangueiras / } \\
\text { ZANETTINI; } \\
\text { MORAES } \\
(2009)\end{array}$ & Baixo Pardo/Grande & $\begin{array}{l}\text { Classificação: Aratu Sapucaí/Uru } \\
\text { Inserção na paisagem: Localiza-se em } \\
\text { meia encosta de colina suave ocupada por } \\
\text { plantio de cana, a } 220 \text { metros da margem } \\
\text { esquerda do Ribeirão das Pitangueiras; } \\
\text { Área do sítio: Área aproximada de } 70 \text { x } \\
100 \text { metros; }\end{array}$ & $\begin{array}{c}22 \mathrm{k} \\
0750784 / 7718445\end{array}$ & $\begin{array}{l}430 \pm 80 \\
\text { A.P. }\end{array}$ & $\begin{array}{l}\text { Técnica de } \\
\text { Termoluminescência } \\
\text { (TL) / }\end{array}$ \\
\hline
\end{tabular}




\begin{tabular}{|c|c|c|c|c|c|c|}
\hline & & & $\begin{array}{l}\text { Quantidade de material: } 44 \text { peças } \\
\text { líticas lascadas e } 09 \text { fragmentos de } \\
\text { cerâmica; } \\
\text { Tipo de Material cerâmico: Não } \\
\text { informado. }\end{array}$ & & & \\
\hline 18 & $\begin{array}{l}\text { Três Jatobás / } \\
\text { FACCIO (2011) }\end{array}$ & $\begin{array}{l}\text { São José dos } \\
\text { Dourados }\end{array}$ & $\begin{array}{l}\text { Classificação: Sem classificação } \\
\text { Inserção na paisagem: sem informação; } \\
\text { Área do sítio: sem informação; } \\
\text { Quantidade de material: } 24 \text { fragmentos } \\
\text { cerâmicos; } \\
\text { Tipo de Material cerâmico: tipo de } \\
\text { antiplástico ( } 95,83 \% \text { mineral, } 4,16 \% \\
\text { mineral associado ao caco-moído); } \\
\text { tratamento de superfície: (100\% liso). }\end{array}$ & $\begin{array}{c}22 \mathrm{k} \\
583065 / 7734282\end{array}$ & $\begin{array}{c}430 \pm 55 \\
\text { A.P. }\end{array}$ & $\begin{array}{l}\text { Técnica de } \\
\text { Termoluminescência } \\
\text { (TL) / } \\
\text { Laboratório de } \\
\text { Datação, Comércios e } \\
\text { Serviços Ltda. }\end{array}$ \\
\hline 19 & $\begin{array}{l}\text { Bambu / } \\
\text { FACCIO (2011) }\end{array}$ & $\begin{array}{l}\text { São José dos } \\
\text { Dourados }\end{array}$ & $\begin{array}{l}\text { Classificação: Sem classificação } \\
\text { Inserção na paisagem: Localizado } \\
\text { próximo a um afluente do Rio São José } \\
\text { dos Dourados; } \\
\text { Área do sítio: Área aproximada de } 50 \text { x } \\
30 \text { metros; } \\
\text { Quantidade de material: } 317 \\
\text { fragmentos de cerâmica, } 38 \text { peças líticas } \\
\text { lascadas e } 01 \text { peça lítica polida; } \\
\text { Tipo de Material cerâmico: tipo de } \\
\text { antiplástico ( } 72,23 \% \text { mineral, 22,71\% } \\
\text { mineral associado ao cariapé e } 5,04 \% \\
\text { mineral associado ao caco-moído); } \\
\text { tratamento de superfície: (99,36\% liso, } \\
0,63 \% \text { decoração plástica). }\end{array}$ & $\begin{array}{c}22 \mathrm{k} \\
565385 / 7743924\end{array}$ & $\begin{array}{l}450 \pm 50 \\
\text { A.P. }\end{array}$ & $\begin{array}{l}\text { Técnica de } \\
\text { Termoluminescência } \\
\text { (TL) / } \\
\text { Laboratório de } \\
\text { Datação, Comércios e } \\
\text { Serviços Ltda. }\end{array}$ \\
\hline 20 & $\begin{array}{l}\text { Dourados / } \\
\text { FACCIO (2011) }\end{array}$ & $\begin{array}{l}\text { São José dos } \\
\text { Dourados }\end{array}$ & $\begin{array}{l}\text { Classificação: Sem classificação } \\
\text { Inserção na paisagem: Localizado a } 100 \\
\text { metros do Rio São José dos Dourados, o } \\
\text { Sítio Dourados fica a aproximadamente } \\
400 \text { metros do Sítio Abelha, separados } \\
\text { geograficamente por uma área úmida; }\end{array}$ & $\begin{array}{c}22 \mathrm{k} \\
583637 / 7734336\end{array}$ & $\begin{array}{c}455 \pm 80 \\
\text { A.P. }\end{array}$ & $\begin{array}{l}\text { Técnica de } \\
\text { Termoluminescência } \\
\text { (TL) / de } \\
\text { Laboratório e } \\
\text { Datação, Comércios e } \\
\text { Serviços Ltda. }\end{array}$ \\
\hline
\end{tabular}




\begin{tabular}{|c|c|c|c|c|c|c|}
\hline & & & $\begin{array}{l}\text { Área do sítio: Área aproximada de } 200 \text { x } \\
40 \text { metros; } \\
\text { Quantidade de material: } 271 \\
\text { fragmentos cerâmicos, } 167 \text { peças líticas } \\
\text { lascadas e } 09 \text { peças líticas polidas; } \\
\text { Tipo de Material cerâmico: tipo de } \\
\text { antiplástico (78,35\% mineral, 13,40\% } \\
\text { mineral associado ao caco moído e 5,15\% } \\
\text { mineral associado ao carvão); tratamento } \\
\text { de superfície: ( } 98,32 \% \% \text { liso, 0,73\% } \\
\text { decoração plástica e } 0,36 \% \text { marcado com } \\
\text { cestaria). }\end{array}$ & & & \\
\hline 21 & $\begin{array}{l}\text { Capão Escuro / } \\
\text { FACCIO } \\
(2012 a)\end{array}$ & Sapucaí/Grande & $\begin{array}{l}\text { Classificação: Sem classificação } \\
\text { Inserção na paisagem: O sítio foi } \\
\text { identificado nas proximidades da APP de } \\
\text { um córrego. Está implantado em área de } \\
\text { média vertente, atualmente destinada ao } \\
\text { plantio de cana-de-açúcar. } \\
\text { Área do sítio: Área aproximada de } 250 \text { x } \\
70 \text { metros; } \\
\text { Quantidade de material: } 04 \text { peças } \\
\text { líticas lascadas, } 01 \text { peça lítica polida e } 45 \\
\text { fragmentos de cerâmica; } \\
\text { Tipo de Material cerâmico: tipo de } \\
\text { antiplástico (100,00\% mineral); } \\
\text { tratamento de superfície: (64,44\% liso, } \\
33,34 \% \text { não identificado e } 2,22 \% \\
\text { decoração plástica [incisa]). }\end{array}$ & $\begin{array}{c}22 \mathrm{k} \\
800056 / 7761245\end{array}$ & $\begin{array}{l}460 \pm 75 \\
\text { A.P. }\end{array}$ & $\begin{array}{l}\text { Técnica de } \\
\text { Termoluminescência } \\
\text { (TL) / } \\
\text { Laboratório de } \\
\text { Datação, Comércios e } \\
\text { Serviços Ltda. }\end{array}$ \\
\hline 22 & $\begin{array}{l}\text { Agua Azul II / } \\
\text { FACCIO } \\
(2012 a)\end{array}$ & Sapucaí/Grande & $\begin{array}{l}\text { Classificação: Aratu-Sapucaí } \\
\text { Inserção na paisagem: Localiza-se em } \\
\text { área de média e baixa vertente, na APP do } \\
\text { Rio Grande e em área de plantio de cana- } \\
\text { de-açúcar; }\end{array}$ & $\begin{array}{c}22 \mathrm{k} \\
774196 / 7770176\end{array}$ & $\begin{array}{l}465 \pm 65 \\
\text { A.P. }\end{array}$ & $\begin{array}{l}\text { Técnica de } \\
\text { Termoluminescência } \\
(\mathrm{TL}) /\end{array}$ \\
\hline
\end{tabular}




\begin{tabular}{|c|c|c|c|c|c|c|}
\hline & & & $\begin{array}{l}\text { Área do sítio: Área aproximada de } 250 \mathrm{x} \\
150 \text { metros; } \\
\text { Quantidade de material: } 55 \text { peças } \\
\text { líticas lascadas e } 484 \text { fragmentos de } \\
\text { cerâmica; } \\
\text { Tipo de Material cerâmico: tipo de } \\
\text { antiplástico ( } 100,00 \% \text { mineral); } \\
\text { tratamento de superfície: (100,00\% liso). }\end{array}$ & & & $\begin{array}{l}\text { Laboratório de } \\
\text { Datação, Comércios e } \\
\text { Serviços Ltda. }\end{array}$ \\
\hline 23 & $\begin{array}{l}\text { Turvo III / } \\
\text { FACCIO (2014) }\end{array}$ & Turvo/Grande & $\begin{array}{l}\text { Classificação: Aratu-Sapucaí } \\
\text { Inserção na paisagem: Situa-se à } \\
\text { margem esquerda do Rio Turvo, há } 100 \\
\text { metros da água e próximo ao Córrego da } \\
\text { Onça. O relevo dessa área é suavemente } \\
\text { inclinado e os artefatos estão localizados } \\
\text { em baixa vertente, próximo a planície } \\
\text { aluvial ou área de inundação do Rio } \\
\text { Turvo; } \\
\text { Área do sítio: } \\
\text { Quantidade de material: } 04 \text { peças } \\
\text { líticas lascadas e } 460 \text { fragmentos de } \\
\text { cerâmica; } \\
\text { Tipo de Material cerâmico: tipo de } \\
\text { antiplástico (100\% mineral associado ao } \\
\text { caco-moído, } 36,00 \% \\
\text { tratamento de superfície: (99,13\% liso, } \\
0,22 \% \text { com decoração plástica } \\
\text { [predominantemente incisa] e } 0,65 \% \text { não } \\
\text { identificado) }\end{array}$ & $\begin{array}{c}22 \mathrm{k} \\
631202 / 7776178\end{array}$ & $\begin{array}{c}480 \pm 70 \\
\text { A.P. }\end{array}$ & $\begin{array}{l}\text { Técnica de } \\
\text { Termoluminescência } \\
\text { (TL) / } \\
\text { Laboratório de } \\
\text { Datação, Comércios e } \\
\text { Serviços Ltda. }\end{array}$ \\
\hline 24 & $\begin{array}{l}\text { Balsamina / } \\
\text { FACCIO } \\
(2012 a)\end{array}$ & Pardo/Grande & $\begin{array}{l}\text { Classificação: Indicativo de tradição } \\
\text { Aratu-Sapucaí (parede de vasilha } \\
\text { conjugada) } \\
\text { Inserção na paisagem: Localiza-se na } \\
\text { média vertente de uma colina aplainada, }\end{array}$ & $\begin{array}{c}22 \mathrm{k} \\
771442 / 7751478\end{array}$ & $\begin{array}{c}485 \pm 65 \\
\text { A.P. }\end{array}$ & $\begin{array}{l}\text { Técnica de } \\
\text { Termoluminescência } \\
(\mathrm{TL}) /\end{array}$ \\
\hline
\end{tabular}




\begin{tabular}{|c|c|c|c|c|c|c|}
\hline & & & $\begin{array}{l}\text { que apresenta um grau de inclinação leve } \\
\text { em cota altimétrica de } 485 \text { metros em } \\
\text { relação ao nível do mar. A fonte de água } \\
\text { mais próxima é o Córrego Balsamina, } \\
\text { que dista, aproximadamente, } 80 \text { metros } \\
\text { do sítio. Notou-se, nas proximidades, a } \\
\text { presença de fontes de argila e } \\
\text { afloramentos de arenito silicificado de } \\
\text { coloração verde; } \\
\text { Área do sítio: Área aproximada de } 450 x \\
260 \text { metros; } \\
\text { Quantidade de material: } 25 \text { fragmentos } \\
\text { de cerâmica; } \\
\text { Tipo de Material cerâmico: tipo de } \\
\text { antiplástico ( } 64,00 \% \text { mineral associado } \\
\text { ao caco-moído, } 36,00 \% \text { mineral); } \\
\text { tratamento de superfície: (96,00\% liso, } \\
4,00 \% \text { com engobo) }\end{array}$ & & & $\begin{array}{l}\text { Laboratório de } \\
\text { Datação, Comércios e } \\
\text { Serviços Ltda. }\end{array}$ \\
\hline 25 & $\begin{array}{l}\text { Santo Antônio } \\
\text { do Lajeado / } \\
\text { FACCIO } \\
(2012 a)\end{array}$ & Pardo/Grande & $\begin{array}{l}\text { Classificação: Aratu-Sapucaí } \\
\text { Inserção na paisagem: Localiza-se nas } \\
\text { proximidades da APP do Córrego do } \\
\text { Jacaré, em área de média vertente; } \\
\text { Área do sítio: Área aproximada de } 180 \text { x } \\
160 \text { metros; } \\
\text { Quantidade de material: } 270 \\
\text { fragmentos de cerâmica; } \\
\text { Tipo de Material cerâmico: tipo de } \\
\text { antiplástico (100,00\% mineral); } \\
\text { tratamento de superfície: (96,29\% liso, } \\
3,33 \% \text { não identificado e } 0,37 \text { decoração } \\
\text { plástica [inciso]); }\end{array}$ & $\begin{array}{c}22 \mathrm{k} \\
771685 / 7744266\end{array}$ & $\begin{array}{c}495 \pm 65 \\
\text { A.P. }\end{array}$ & $\begin{array}{l}\text { Técnica de } \\
\text { Termoluminescência } \\
\text { (TL) / } \\
\text { Laboratório de } \\
\text { Datação, Comércios e } \\
\text { Serviços Ltda. }\end{array}$ \\
\hline
\end{tabular}




\begin{tabular}{|c|c|c|c|c|c|c|}
\hline 26 & $\begin{array}{l}\text { Turvo V b / } \\
\text { FACCIO (2014) }\end{array}$ & Turvo/Grande & $\begin{array}{l}\text { Classificação: Aratu-Sapucaí } \\
\text { Inserção na paisagem: Localiza-se na } \\
\text { margem esquerda do Córrego do Anil, } \\
\text { distante cerca de } 800 \text { metros do seu } \\
\text { encontro com o Rio Turvo. Situa-se numa } \\
\text { colina ampla de vertente levemente } \\
\text { acentuada e topo aplainado e fica } \\
\text { localizado na baixa vertente. } \\
\text { Área do sítio: } \\
\text { Quantidade de material: } 09 \text { peças } \\
\text { líticas lascadas e } 32095 \text { fragmentos de } \\
\text { cerâmica. } \\
\text { Tipo de Material cerâmico: tipo de } \\
\text { antiplástico (100,00\% mineral); } \\
\text { tratamento de superfície: (99,53\% liso, } \\
0,43 \% \text { com decoração plástica } \\
\text { [predominantemente incisa] e } 0,04 \% \text { com } \\
\text { engobo) }\end{array}$ & $\begin{array}{c}22 \mathrm{k} \\
632070 / 7774898\end{array}$ & $\begin{array}{l}600 \pm 100 \\
\text { A.P. }\end{array}$ & $\begin{array}{l}\text { Técnica de } \\
\text { Termoluminescência } \\
\text { (TL) / } \\
\text { Laboratório de } \\
\text { Datação, Comércios e } \\
\text { Serviços Ltda. }\end{array}$ \\
\hline 27 & $\begin{array}{l}\text { Menino Jesus / } \\
\text { FACCIO (2015) }\end{array}$ & Rio Grande & $\begin{array}{l}\text { Classificação: Aratu-Sapucaí } \\
\text { Tupiguarani/ Uru } \\
\text { Inserção na paisagem: Situa-se em área } \\
\text { de depleção da represa da UHE- } \\
\text { Marimbondo, próximo as duas margens } \\
\text { do córrego Menino Jesus, se estendendo } \\
\text { a margem do Rio Grande lado paulista. } \\
\text { Área do sítio: } \\
\text { Quantidade de material: } 171 \text { peças } \\
\text { líticas lascadas, } 13 \text { peças líticas polidas e } \\
3130 \text { fragmentos de cerâmica. } \\
\text { Tipo de Material cerâmico: tipo de } \\
\text { antiplástico ( } 74,50 \% \text { mineral associado a } \\
\text { hematita, } 22,73 \% \text { mineral, } 2,46 \% \text { mineral } \\
\text { associado a hematita e caulinita e } 0,31 \% \\
\text { mineral associado ao carvão); tratamento } \\
\text { de superfície: (96,89\% liso, } 1,46 \% \text { com }\end{array}$ & $\begin{array}{c}22 \mathrm{k} \\
692930 / 7752164\end{array}$ & $\begin{array}{c}600 \pm 70 \\
\text { A.P. } \\
715 \pm 55 \\
\text { A.P. }\end{array}$ & $\begin{array}{l}\text { Técnica de } \\
\text { Termoluminescência } \\
\text { (TL) / } \\
\text { Laboratório de } \\
\text { Datação, Comércios e } \\
\text { Serviços Ltda. }\end{array}$ \\
\hline
\end{tabular}




\begin{tabular}{|c|c|c|c|c|c|c|}
\hline & & & $\begin{array}{l}\text { engobo, } 1,07 \% \text { decoração plástica, } 0,3 \% \\
\text { com pintura) }\end{array}$ & & & \\
\hline 28 & $\begin{array}{l}\text { Turvo I / } \\
\text { FACCIO (2014) }\end{array}$ & Turvo/Grande & $\begin{array}{l}\text { Classificação: Aratu-Sapucaí } \\
\text { Inserção na paisagem: O sítio está } \\
\text { situado na confluência do Córrego do } \\
\text { Paiol (margem esquerda) e do Rio Turvo, } \\
\text { em média vertente, distante } \\
\text { aproximadamente a } 200 \text { metros da água; } \\
\text { Área do sítio: Área de aproximadamente } \\
300 \text { x } 80 \text { metros } \\
\text { Quantidade de material: } 61 \text { peças } \\
\text { líticas lascadas e } 5988 \text { fragmentos de } \\
\text { cerâmica; } \\
\text { Tipo de Material cerâmico: tipo de } \\
\text { antiplástico ( } 64,00 \% \text { mineral associado } \\
\text { ao caco-moído, } 36,00 \% \text { mineral); } \\
\text { tratamento de superfície: ( } 99,89 \% \text { liso e } \\
0,10 \% \text { com decoração plástica } \\
\text { [predominantemente incisa]) }\end{array}$ & $\begin{array}{c}22 \mathrm{k} \\
626490 / 7777683\end{array}$ & $\begin{array}{l}610 \pm 80 \\
\text { A.P. }\end{array}$ & $\begin{array}{l}\text { Técnica de } \\
\text { Termoluminescência } \\
\text { (TL) / } \\
\text { Laboratório de } \\
\text { Datação, Comércios e } \\
\text { Serviços Ltda. }\end{array}$ \\
\hline 29 & $\begin{array}{l}\text { Turvo II / } \\
\text { FACCIO (2014) }\end{array}$ & Turvo/Grande & $\begin{array}{l}\text { Classificação: Aratu-Sapucaí } \\
\text { Inserção na paisagem: Localiza-se na } \\
\text { confluência do córrego do Paiol (margem } \\
\text { direita) e do Rio Turvo, em média } \\
\text { vertente de uma colina aplainada. O sítio } \\
\text { Turvo II está a cerca de } 1 \text { km de distância } \\
\text { do Sítio Turvo I, separados } \\
\text { geograficamente pelo córrego do Paiol, o } \\
\text { que pode indicar uma relação próxima } \\
\text { entre as distintas ocupações; } \\
\text { Área do sítio: Área de aproximadamente } \\
250 \text { metros x } 80 \text { metros; } \\
\text { Quantidade de material: } 130 \text { peças } \\
\text { líticas lascadas, } 16 \text { peças líticas polidas e } \\
2631 \text { fragmentos de cerâmica; }\end{array}$ & $\begin{array}{c}22 \mathrm{k} \\
627330 / 7778617\end{array}$ & $\begin{array}{l}610 \pm 90 \\
\text { A.P. }\end{array}$ & $\begin{array}{l}\text { Técnica de } \\
\text { Termoluminescência } \\
\text { (TL) / } \\
\text { Laboratório de } \\
\text { Datação, Comércios e } \\
\text { Serviços Ltda. }\end{array}$ \\
\hline
\end{tabular}




\begin{tabular}{|c|c|c|c|c|c|c|}
\hline & & & $\begin{array}{l}\text { Tipo de Material cerâmico: tipo de } \\
\text { antiplástico }(100,00 \% \text { mineral }) \text {; } \\
\text { tratamento de superfície: }(100,00 \% \text { liso }) \text {. }\end{array}$ & & & \\
\hline 30 & $\begin{array}{l}\text { Água Vermelha / } \\
\text { ROBHRAN } \\
\text { GONZÁLEZ } \\
\text { (1998) }\end{array}$ & Rio Grande & $\begin{array}{l}\text { Classificação: Tupiguarani/Uru } \\
\text { Inserção na paisagem: Localiza-se a } \\
\text { jusante do eixo da Usina Hidrelétrica de } \\
\text { mesmo nome, no baixo rio Grande, limite } \\
\text { dos Estados de São Paulo e Minas Gerais. } \\
\text { Está implantado em antiga planície } \\
\text { fluvial da Cachoeira dos Índios, estando } \\
\text { hoje parcialmente submerso pela represa } \\
\text { da UHE Água Vermelha. } \\
\text { Área do sítio: Área aproximada de } 40 \text { x } \\
60 \text { metros (considerando que trata-se de } \\
\text { um sítio parcialmente inundado); } \\
\text { Quantidade de material: } \\
\text { fragmentos cerâmicos e 15.142 peças } \\
\text { líticas lascadas, } 08 \text { peças líticas polidas, } \\
02 \text { peças em ossos, } 01 \text { peça em madeira e } \\
15 \text { sepultamentos humanos; } \\
\text { Tipo de Material cerâmico: tipo de } \\
\text { antiplástico (cariapé, caco-moído e } \\
\text { mineral, não sendo informado as suas } \\
\text { respectivas porcentagens); tratamento de } \\
\text { superfície: (100,00\% liso). }\end{array}$ & $\begin{array}{c}22 \mathrm{k} \\
566618 / 7804076\end{array}$ & $\begin{array}{l}700 \pm 70 \\
\text { A.P. } \\
1010 \pm 50 \\
\text { A.P. }\end{array}$ & $\begin{array}{l}\text { Datação por } \\
\text { Radiocarbono BETA } \\
\text { ANALYTIC INC }\end{array}$ \\
\hline 31 & $\begin{array}{l}\text { Turvo IV / } \\
\text { FACCIO (2014) }\end{array}$ & Turvo/Grande & $\begin{array}{l}\text { Classificação: Aratu-Sapucaí } \\
\text { Inserção na paisagem: Localiza-se na } \\
\text { margem esquerda do Córrego da Onça, } \\
\text { muito próximo a água ( } 20 \text { metros) em } \\
\text { baixa vertente, distante } 300 \text { metros do } \\
\text { Sítio Turvo III. O material arqueológico } \\
\text { estava espalhado entre os talhões de cana- } \\
\text { de-açúcar; } \\
\text { Área do sítio: Área aproximada de } 150 \text { x } \\
100 \text { metros; }\end{array}$ & $\begin{array}{c}22 k \\
631006 / 7775612\end{array}$ & $\begin{array}{c}740 \pm 95 \\
\text { A.P. }\end{array}$ & $\begin{array}{l}\text { Técnica de } \\
\text { Termoluminescência } \\
\text { (TL) / } \\
\text { Laboratório de } \\
\text { Datação, Comércios e } \\
\text { Serviços Ltda. }\end{array}$ \\
\hline
\end{tabular}




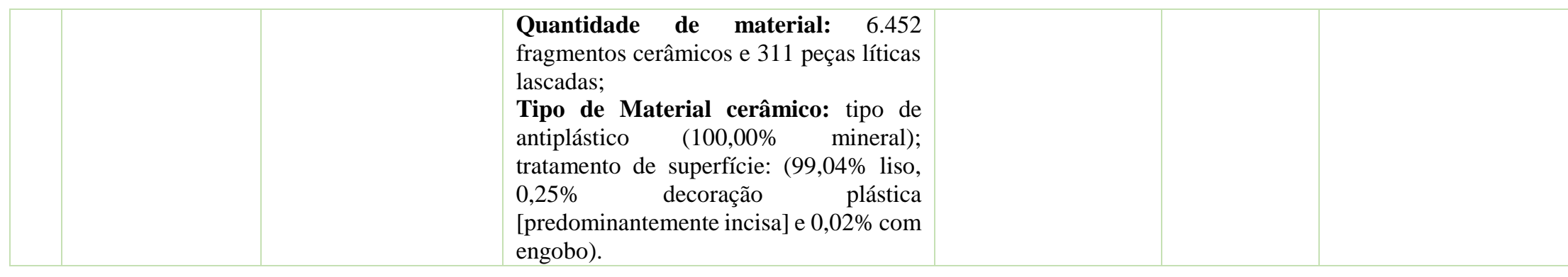


ANEXO 2- Laudo de datação de fragmentos cerâmicos pelo método da Termoluminescência (TL) e pelo método da Luminescência Oticamente Estimulada (LOE). 